\title{
WestVirginiaUniversity
}

THE RESEARCH REPOSITORY @ WVU

Graduate Theses, Dissertations, and Problem Reports

2018

\section{How Will Anthropogenic Valley Fills in Appalachian Headwaters Erode?}

Miles Reed

Follow this and additional works at: https://researchrepository.wvu.edu/etd

\section{Recommended Citation}

Reed, Miles, "How Will Anthropogenic Valley Fills in Appalachian Headwaters Erode?" (2018). Graduate Theses, Dissertations, and Problem Reports. 6490.

https://researchrepository.wvu.edu/etd/6490

This Thesis is protected by copyright and/or related rights. It has been brought to you by the The Research Repository @ WVU with permission from the rights-holder(s). You are free to use this Thesis in any way that is permitted by the copyright and related rights legislation that applies to your use. For other uses you must obtain permission from the rights-holder(s) directly, unless additional rights are indicated by a Creative Commons license in the record and/ or on the work itself. This Thesis has been accepted for inclusion in WVU Graduate Theses, Dissertations, and Problem Reports collection by an authorized administrator of The Research Repository @ WVU. For more information, please contact researchrepository@mail.wvu.edu. 
How will anthropogenic valley fills in Appalachian headwaters erode?

\author{
Miles Reed \\ Thesis submitted \\ to the Eberly College of Arts and Sciences \\ at West Virginia University \\ in partial fulfillment of the requirements for the degree of \\ Master of Science in \\ Geology
}

Steve Kite, Ph.D., Chair

Aaron Maxwell, Ph.D.

Nick Zègre, Ph.D.

Department of Geology and Geography

Morgantown, West Virginia

2018

Keywords: anthropogenic geomorphology, surface mining erosion, valley fill, lidar, gullies Copyright 2018 Miles Reed 


\begin{abstract}
How will anthropogenic valley fills in Appalachian headwaters erode?
\end{abstract}

\title{
Miles Reed
}

Mountaintop removal/valley fill (MTR/VF) coal mining in the Central Appalachian region has created the most extreme anthropogenic landscape on Earth by lowering ridges and infilling headwater stream valleys. No studies have attempted to detail erosional processes active on MTR/VR landforms. A combination of field work and LiDAR data observations documents erosional features on MTR/VF landscapes. Landscape evolution modeling explores future possibilities in valley-filled catchments. LiDAR data also allows for the quantification of valley-filled catchment alteration with statistically significant differences in both drainage density and depression storage capacity between "less disturbed" and valley-filled catchments. Field and LiDAR data observations show that the drainage systems associated with the periphery of the MTR/VF landscape are particularly vulnerable to gully erosion. This study also provides evidence of landslides occurring within fully reclaimed valley fills. Landscape evolution modeling reproduces gully erosion mechanisms documents in the field. Modeled erosion rates based solely on bedload averaged $10.9 \mathrm{~mm} \mathrm{kyr}^{-1}$. Modeled erosion rates are higher on valley fills with constructed drains in the center of the valley fill relative to those with drains along the sides. 


\section{Dedication}

I dedicate my thesis to Mark Langly Reed, my father. I owe my love of landscapes to him. You will never be forgotten. 


\section{Acknowledgements}

I would like to thank Dr. Steve Kite (my advisor @ WVU), Dr. Aaron Maxwell (committee member, WVU), Dr. Nicolas Zègre (committee member, WVU), Dr. Chris Ryan (WVDNR), Randy Kelley

(WVDNR), Dr. Tom Coulthard (University of Hull), Dr. Matthew Ross (UNC-Chapel Hill), Dr. Kristin Jager (USGS), and especially, Lynnette Eichenlaub. 


\section{Table of Contents}

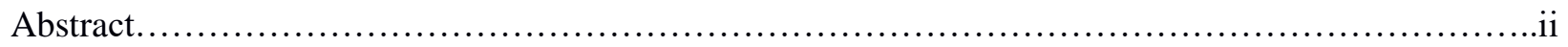

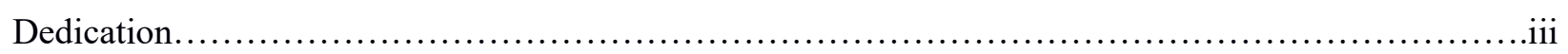

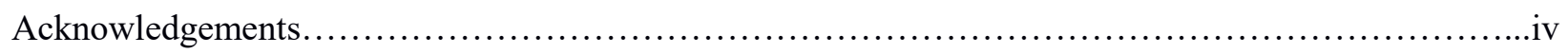

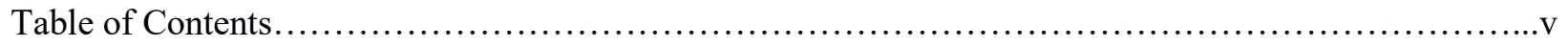

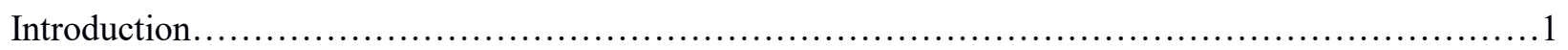

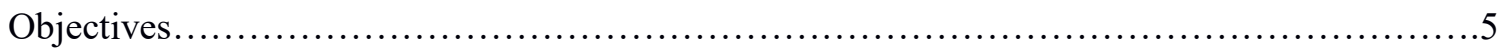

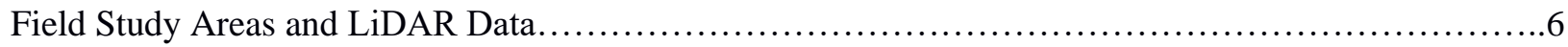

Field Study Areas and Background.................................................6

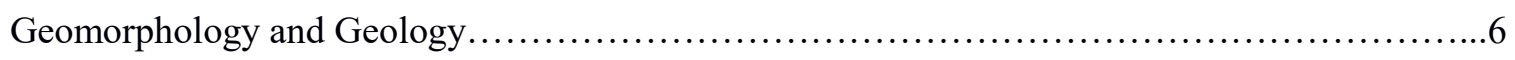

Climate and Vegetation..............................................................

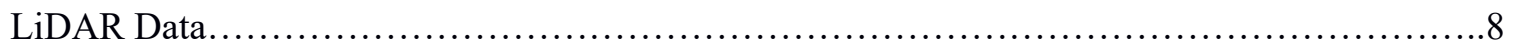

Methods............................................................................

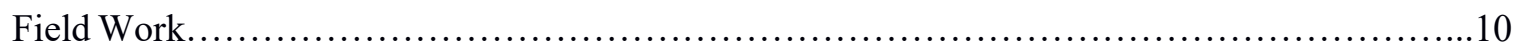

LiDAR Data Observations..........................................................11

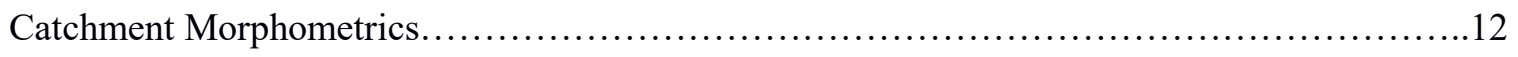

Depression Storage Capacity.................................................... 14

CAESAR-Lisflood Landscape Evolution Modeling.....................................15

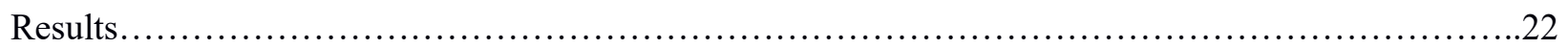

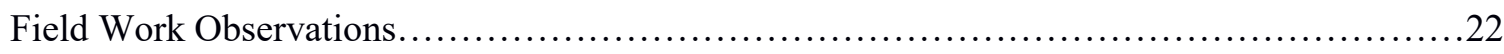

LiDAR Data Observations of Erosional Landforms...................................27

Gullies..................................................................27

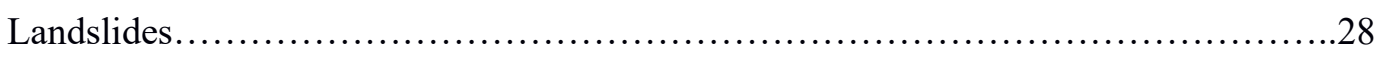

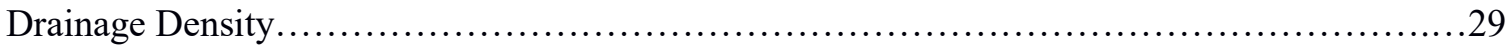

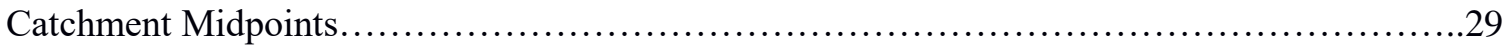

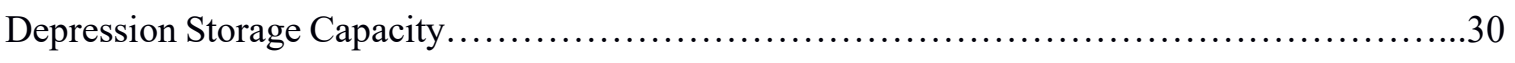

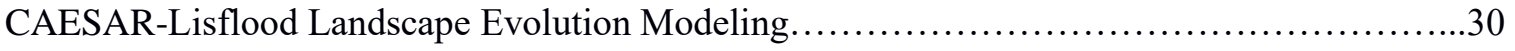

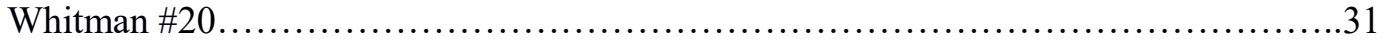

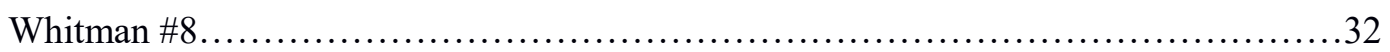

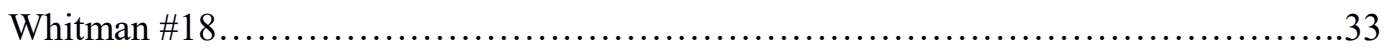

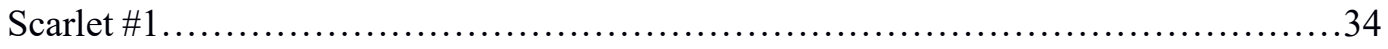




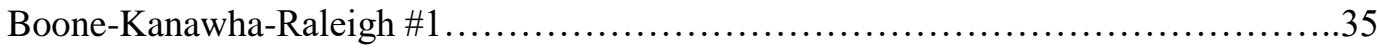

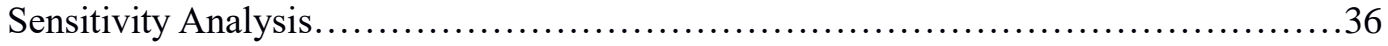

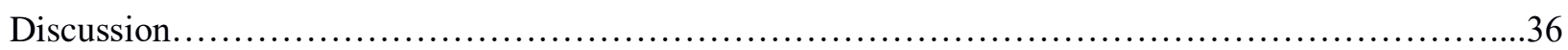

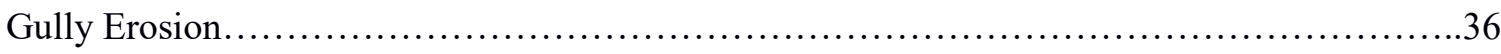

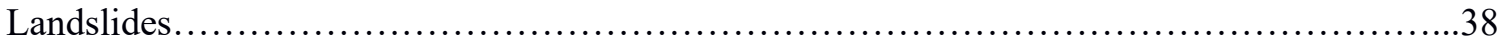

Drainage Density and Depression Storage Capacity.....................................38

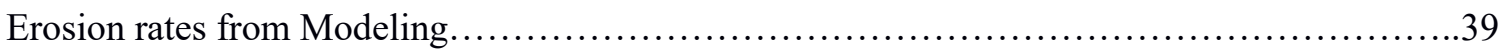

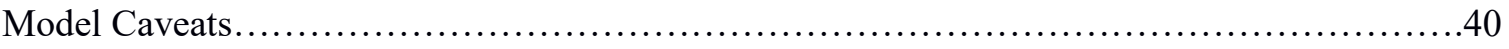

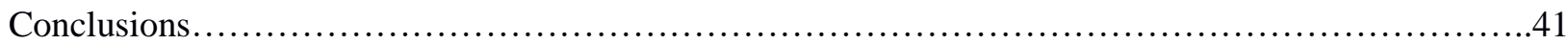

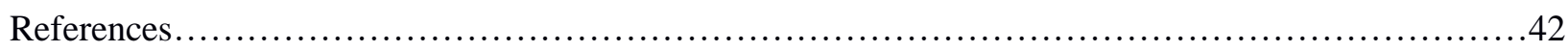

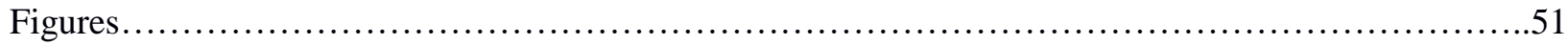

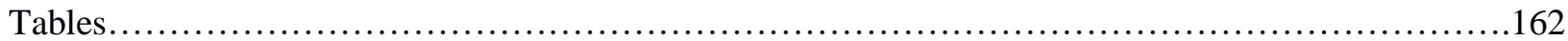




\section{Introduction}

Humans are the primary geomorphic agents on the planet (Hooke, 1999; Hooke, 2000; Syvitski et al., 2005). Surface mining is a potent example of this extraordinary geomorphic work rate (Haigh, 1992;

Tarolli and Sofia, 2016). Mountaintop removal/valley-fill mining (MTR/VF) (Fig. 1) is a coal surface mining technique in which the top 50-125 meters of a ridge is blasted and hauled away to mine interbedded and underlying coal. The rock above and between coal layers increases in volume during mining, necessitating the storage of materials in nearby headwater valleys as a large, wedge-shaped anthropogenic deposits (Fig. 2) (Michael and Superfesky, 2007). MTR/VF has driven land-use change over the past several decades in the unglaciated Appalachian Plateaus of Central Appalachia and is uniquely practiced there (Fig. 3) (Townsend et al., 2009). The environmental impacts resulting from the burial of headwater streams by this practice has been extensively documented in studies of downstream water chemistry and aquatic ecosystems (Griffith et al., 2012; Pond et al., 2008; Bernhardt and Palmer, 2011). How these landforms will evolve geomorphologically has yet to be determined (Kite, 2009).

The Surface Mining Control and Reclamation Act of 1977 (SMCRA) was introduced to minimize environmentally damaging practices involved in the haphazard storage of excess mine spoil and to insure mining sites were reclaimed to a form that the sites resembled prior to mining, approximate original contour (AOC) (Haering et al., 2004). The rugged topography of Central Appalachia motivated a geographically restricted variance to AOC under SMCRA (Zipper et al., 1989), which allows for the construction of valley fills. Valley fills are anthropogenic landforms created when excess rock and soil are placed into headwater valleys adjacent to mined areas during MTR/VF. The general geometric shape exhibited by these valley fills is common among reclaimed mining landforms worldwide (Martin-Duque et al., 2010). Valley fills sampled in the United States Office of Surface Mining (OSM) Long-Term Stability of Valley Fills Report (2002) ranged in length from 90 to $3000 \mathrm{~m}$ and in volume from 0.15 to 152 million $\mathrm{m}^{3}$. There were over 6000 valley fills in the coalfields of southern West Virginia, eastern Kentucky, southwestern Virginia and north-central Tennessee as of 2002 (EPA, 2011). The amount of 
sediment contained in 1544 West Virginia valley fills studied in Ross et al. (2016) was estimated to be 6.4 $\mathrm{km}^{3}$. Valley fills are normally constructed with the durable rock method in which excess materials deemed $80 \%$ durable rock (i.e. will not slake into fine particles) are dumped into a headwater stream valley and are segregated by particle size through downslope grain flow (Michael and Supefesky, 2010). The dumped rock is then bulldozed into 2:1 slopes with intervening slope-length-limiting terraces and armored by heavily compacted surface materials (Schor and Gray, 2007).

The geomorphology and the hydrology of an area are inextricably linked as topographic position within a catchment can influence runoff processes (Beven and Kirkby, 1979). Surface mining drastically alters the hydrology of affected areas by changing both topography and surface materials (Ostercamp et al., 2000). The durable rock method involves the creation of a highly permeable underdrain at the base of the valley fill by the gravity segregation of mining-generated regolith during downslope dumping. This underdrain is intended to drain infiltrating water to the toe of the valley fill (OSM, 2002). The underdrain formation concept broadly agrees with the models of scree slope development of Kirkby and Statham (1975), but poor underdrain formation has been documented due to usage of weathered rock and dumping onto exceptionally long slopes (Michael and Superfesky, 2007). Rock-lined drains on the valley fill surface provide runoff conduits. The drains can be positioned along the sides of the valley fill (groin drains) or in the center (Fig. 4), and are designed to withstand a 6 hour, 100-year precipitation event (OSM, 2002). Miller and Zegre (2014) developed a conceptual model of the hydrology of MTR/VR landscapes in which the valley fill may act as storage of water that increases base flow by a slow release of water via tortuous flow around grains. High-intensity precipitation events may initiate more rapid flow through macropores in the valley fill (Miller and Zegre, 2014). The inferred occurrence of macropore flow in valley fills follows from previous investigations of surface mine spoil where macropores were found to develop after several years and acted as psuedokarst (Guebert and Gardner, 2001; Hawkins and Aljoe, 1992). Heavy compaction in mine soil by machinery for stability purposes was shown to restrict vertical and lateral 
drainage in soil (Haering et al., 2004). The dominant runoff generation processes are still undetermined in MTR/VF landscapes (Miller and Zegre, 2014), and may benefit from geomorphologic studies.

OSM (2002, p. 39) guidance states that "The results of the study indicate that most reclaimed fills are evolving into stable landforms" as there have only been 40 documented landslides (all in non-reclaimed valley fills) at the time of the OSM Long-term Stability of Valley Fills Report (OSM, 2002, p. 40). The assertion that valley fills are evolving into stable landforms does not comport with previous studies on the erosion of pre-SMCRA mine spoil materials or the study of other mining landforms, which generally have shown accelerated erosion rates. (Collier, 1964; Curtis and Supefesky, 1977; Martin-Duque et al., 2010). Collier (1964) found that sediment load was elevated due to gully, sheet and rill erosion on preSMCRA mining landforms in the heavily surface mined Cane Branch watershed in south-central Kentucky compared to the unmined Helton Branch. During a long-term study, Dyer and Curtis (1977) found $30 \%$ higher storm-runoff suspended-sediment loads compared to pre-mining loads on the Tradewater River in Kentucky. It is difficult to determine how these pre-SMCRA studies compare to MTR/VF landscapes, as the constructed landforms must comply with more rigid regulations concerning geometry and materials (Zipper et al., 1989). Hancock et al. (2003) observed severe gully erosion on reclaimed uranium mines in Australia. Gully erosion appears to be a common phenomenon on other geometrically designed mine reclamation landscapes in varied climates (Haigh, 1980; Sawatsky and Tuttle, 1996; Sanz et. al, 2008). The widespread observation of accelerated erosion on mining landforms has led some researchers to advocate geomorphic landform design, which seeks to create reclamation landscapes that more accurately mimic pre-existing hydrologic and geomorphic regimes (Schor and Gray, 2007; DePriest et al., 2015).

Geomorphic studies on MTR/VF affected areas have been limited (Jaeger, 2015). Wiley et al. (2001) observed a higher percentage of sediment grains $<2 \mathrm{~mm}$ in diameter and a lower median grain size in West Virginia streams with valley-filled headwaters compared to those without. Fox (2009) found enhanced stream bank erosion in streams with valley-filled headwaters using carbon isotopes. 
Downstream channel morphology in MTR/VR affected streams were seen to have more exposed bedrock, deeper channels, and more fine-grained sediments compared to unaffected streams (Jaeger, 2015). Maxwell and Strager (2013) showed a shallowing of hillslopes and more flat land in MTR/VF landscapes in southwestern West Virginia using a comparison of post-mining Light Dectection and Ranging (LiDAR) and pre-mining photogrammetric digital elevation models (DEMs). In the OSM stability report (2002), 34\% of sampled bonded valley fills showed signs of erosion. These problems were fixed because maintenance is required while under the SMCRA reclamation bond (OSM, 2002). Once valley fills have met the regulatory reclamation bond requirements, government agencies require no further maintenance (Michael and Superfesky, 2010).

Headwater streams are the largest portion of total length in a river system (Benda et al., 2005). The eroding nature of steep headwater streams in Central Appalachia is well documented (Hack and Goodlett, 1960; Cenderelli and Kite, 1998; Taylor and Kite, 2006). Debris flows and other mass wasting processes evacuate sediment collected in colluvial hollows and low-order streams in the steep topography of southwestern West Virginia where MTR/VF is practiced (Outerbridge, 1987). It stands to reason that large anthropogenic deposits in Appalachian headwaters will be susceptible to erosion over long timescales. The timescale upon which unmined Appalachian headwater streams evacuate most sediment may be millennial (Eaton et al., 2003), suggesting that a modeling approach will provide additional insights into assessing long-term stability of valley fills. Landscape evolution modeling is a numerical modeling technique in which governing equations, representing geomorphological processes, are solved iteratively to produce altered DEMs from initial DEMs at timescales that preclude human observation (Tucker and Hancock, 2010). Landscape evolution modeling allows for realistic modeling of geomorphic trajectories with changes in elevation and connectivity that are not possible in topographically static models like the revised universal soil loss equation, RUSLE (Hancock, 2004). The CAESAR-Lisflood (CL) landscape evolution model used in this study combines a non-steady routing of water flow and sediment with geomorphic processes such as soil creep and mass wasting to capture landscape evolution 
on a millennial timescale or shorter (Coulthard et al., 2013). This model was used recently to investigate uranium mining reclamation landforms in Australia (Hancock et al., 2015).

The aim of this pilot study is to determine how valley fills are eroding at a process-level by studying the resultant landforms. The study represents the first attempt to study MTR/VF from a geomorphic perspective on reclaimed valley fills using fieldwork, LiDAR and landscape evolution modeling. The field assessment of erosional landforms lends credence to LiDAR-based remote sensing observations (Roering et al., 2013). Landscape evolution modeling of anthropogenic valley fill deposits represents the first attempt to understand the long-term development of these extensive landforms in Central Appalachian headwaters. LiDAR-derived catchment-scale morphometrics, such as drainage density depression storage capacity, may help better understand the altered hydrology of valley-filled catchments. The study was undertaken under the working hypothesis that valley fills will be eroded via gully erosion.

\section{Objectives}

The research objectives of this study are as follows:

- Describe and photograph erosional features on valley fills found during field work

- Describe and quantify LiDAR observations of landslides and gullies

- Explain and justify parameterization of the CL landscape evolution model

- Describe quantitative and qualitative data stemming from 1000-year runs of the CL landscape evolution model using valley-filled catchments 


\section{Field Study Areas and LiDAR Data}

\section{Field Study Areas and Background}

The West Virginia Division of Natural Resources (WVDNR) acquired land in the southern West Virginia coalfields in 2016 with the intent of restoring an elk population. Two elk restoration sites with valley fills were chosen as field study areas: EIP Copperas and Whitman West. The field study areas are located $\sim 10$ $\mathrm{km}$ southwest of Logan, West Virginia (Fig. 5). EIP Copperas (EIP) is $17.5 \mathrm{~km}^{2}$ and Whitman is 23.6 $\mathrm{km}^{2}$. Combined, the field study areas contain 29 valley fills, with nine on EIP and 20 on Whitman. EIP has the largest individual valley fill with an area of $0.18 \mathrm{~km}^{2}$. The valley fills in the field study areas have either groin or center drains. Two valley fills on Whitman were determined to be composed of finegrained coal refuse based on field observations of abundant coal fragments in the fill material. Right-ofentry was obtained from the WVDNR under the agreement that no destructive sampling (e.g., soil pits) would be undertaken. The field study areas are situated in the Upper Guyandotte River headwaters in the historic habitat range of the Guyandotte River Crayfish (Cambarus veteranus), which was recently listed as an endangered species (Welsh et al., 2016). Whitman is primarily drained by Whitman Creek, and EIP is drained by Copperas Mine Fork.

\section{Geormorphology and Geology}

The study areas are in the unglaciated Appalachian Plateaus physiographic province (Fenneman, 1938) in the Logan Plateau physiographic region proposed by Outerbridge (1987). The region is highly dissected with steep slopes averaging $26^{\circ}$ (Outerbridge, 1987). Hillslopes are generally covered in coarse colluvium originating as debris flows and slumps (Outerbridge, 1987). From one year (1974-1975) of dissolved and suspended sediment data, Ehlke et al. (1982) estimated an erosion rate of $69 \mathrm{~m} \mathrm{Myr}^{-1}$ in the Guyandotte River watershed at Logan, West Virginia (10 km from WW). No contemporary erosion rates for the area are available. Natural erosion rates measured elsewhere in the unglaciated Appalachian Plateaus of Central Appalachians range from 56.0-63.2 $\mathrm{m} \mathrm{Myr}^{-1}$ in the Cheat River, West Virginia (Springer et al., 
1997), to $5.7 \mathrm{~m} \mathrm{Myr}^{-1}$ on Pottsville sandstone ridges located near the Allegheny Front in West Virginia (Hancock and Kirwan, 2007). Soils in the study areas are Dystrudepts on undisturbed slopes and ridges while Udorthents occur on surface mined areas (Soil Survey Staff, 2016).

The geology of the study areas can be described as Middle Pennsylvanian interbedded sandstone, siltstone, limestone and coal, dipping slightly to the northeast (Greb et al., 2008). The ridges are, or were in the case of MTR/VR affected areas, capped by the basal portion of the Allegheny Formation with valleys and hillslopes underlain by Kanawha Formation per the West Virginia Geologic and Economic Survey Coal Bed Mapping project shapefiles (Fig. 6) (WVGES, 2013). Fedorko and Blake (1998) showed that most MTR/VF mining targets an interval from the Coalburg coal in the Upper Kanawha Formation to the Number 6 Block coal in the overlying Allegheny Formation. The Upper Kanawha Formation in southern West Virginia has been described by Martino (1996, pg. 1) as "lithic sandstone and mudrocks with subordinate coal and impure limestone" with both marine and non-marine facies. The Allegheny Formation contains thick feldspathic sandstones, shale and coal (Englund et al., 1986). The geologic materials composing the valley fills in the field study areas will be assumed to be very similar as the area of valley fills in each study area is roughly proportional to the extent of Allegheny Formation within a study area (Fig. 6). LiDAR observations were also made in eastern Kentucky (Section 2.3.2). In Kentucky, the equivalent lithostratographic units are the Four Corners and Princess formations of the Breathitt Group (Huddle and England, 1966), which may have been more distal in the Central Appalachian Basin relative to the West Virginia units (Chestnut, 1993). Lower measured internal angle of friction measurements from bulk samples of Kentucky valley fill material suggests the rocks are finer grained (OSM, 2002). Geology in areas covered by LiDAR datasets used in this study is assumed to be heterogeneous.

\section{Climate and Vegetation}

The climate of the study areas is characterized as humid continental with cold winters and warm summers (Kottek et al., 2006). The dominant vegetation is mixed mesophytic forest in undisturbed areas 
(Strausbaugh and Core, 1978). Grasslands generally dominate lands disturbed by MTR/VF mining as the heavily compacted soil does not readily support native trees (Zipper et al., 2011). The field study areas located near Logan, West Virginia $(37.8716,-81.9947)$, have a mean January temperature of $1.4^{\circ} \mathrm{C}$ and mean July temperature of $25.1^{\circ} \mathrm{C}$; mean annual rainfall is $1178 \mathrm{~mm}$, peaking with mean monthly rainfall of 129 mm from May until July (PRISM Climate Group, 2015). Large convective storms occur during summer, such as the July 2001 series of storms that delivered 76-152 mm of rain in 24 hours southeast of

the study areas and triggered landslides within valley fills, which were observed during post-storm aerial reconnaissance (Evaldi, 2001). The Central Appalachians can experience some of the highest rainfall intensity rates on Earth for durations below 6 hours (Smith et al., 2011). Climate models predict that precipitation intensity will increase in the Central Appalachians due to climate change (Fischer et al., 2013).

\section{LiDAR Data}

High-resolution LiDAR data from the Southern coalfields of West Virginia and the Eastern coalfields of Kentucky were used throughout this study. The West Virginia data were obtained from the West Virginia Division of Natural Resources Technical Applications and GIS Unit (TAGIS) LiDAR repository (http://tagis.dep.wv.gov/data/lidar). These LiDAR data were gathered for the West Virginia Division of Environmental Protection Department of Mining and Reclamation by the Natural Resource Analysis Center of West Virginia University. The LiDAR data were flown during leaf-off conditions from 11 Oct 2010 to 22 Oct 2010 using an Optech ALTM-3100 sensor. The LiDAR data are publicly available as classified $2.25 \mathrm{~km}^{2}$ LAS v1.2 files with a NAVD88/NAD83 UTM Zone 17N geodetic reference system and $1 \mathrm{~m}$ average post spacing. Field assessment showed the classified ground returns to have a median vertical accuracy of $0.141 \mathrm{~m}$ in open terrain and $0.188 \mathrm{~m}$ in brushy settings in a test conducted by a

company contracted by the Federal Emergency Management Association (Risk Assessment and Security Partners, 2012). All West Virginia LiDAR data were interpolated into $1 \mathrm{~m}$ DEMs in ArcMap using linear 
void filling. The West Virginia LiDAR datasets showed minimal interpolation artifacts based on visual inspection.

The Kentucky LiDAR data were obtained from the Kentucky Geographic Network, KyGeoPortal (http://kygisserver.ky.gov/geoportal), as classified ground LAZ files (compressed LAS). The LiDAR data were flown by the state of Kentucky in the winter of 2011-2012. The Kentucky LiDAR data are georeferenced to the Kentucky Single Zone State Plane coordinate system (measured in feet), and has an average post spacing of $0.68 \mathrm{~m}$. The stated vertical accuracy is $0.15 \mathrm{~m}$. The Kentucky LiDAR data were rendered in ArcMap at $3 \mathrm{ft}(0.914 \mathrm{~m})$ resolution with linear void filling.

\section{Methods}

\section{Field Work}

Twenty-one valley-filled catchments were explored within the field study areas to assess the extent and types of erosional landforms. Two valley-filled catchments were seen to be composed of coal refuse material and will be referred to from hereafter as refuse fills. Mitigation work had recently been completed on one valley fill catchment. The assessment was spatially focused on the faces, drains, and the interfaces between sideslopes and faces (Fig. 2). The intent of the field work was to understand on-going erosional processes shaping valley fills, to provide much needed context to LiDAR observations, and collect data required to parameterize the CL landscape evolution model. Fifteen catchments in Whitman and six in EIP were assessed (Table 1). The ages of valley fills were derived from a GIS database created by the West Virginia Department of Environmental Protection. Each valley-filled catchment took one to three field days to assess. An assessment would begin at the top of the catchment and proceed towards the outlet stream near the toe by traversing along each terrace flat (Fig. 7). LiDAR-derived slopeshades of the catchments loaded onto a tablet computer served as guides to potential erosional features (Roering et al., 2013). If an erosional feature was encountered, it's dimensions were measured by measuring tape with location noted by GPS using a Bad Elf GNSS Surveyor. Raw GPS data were recorded while remaining 
completely stationary for over two minutes for later post-processing. Erosional features were documented with a 20.1 Megapixel digital camera. A causal mechanism was sought for each gully that was encountered (e.g., an overtopped sediment cell) (Reed and Kite, 2017). Locations and dimensions of seeps (occurring outside of constructed drains) and patches of bare ground on valley fill faces were recorded. Other observations, such as small landslides and fluvial erosion of colluvial slopes near valley fill margins, were also documented. Sideslopes were investigated if an erosional feature originating on the sideslope was seen to be interacting with the valley fill or was clearly visible on the LiDAR slopeshade.

Thirteen pebble counts of $\sim 100$ blindly selected clasts within constructed drains were conducted upon homogenous patches of sediment which looked to be influenced by fluvial activity (Kondolf, 1997). Larger structural boulders used to construct the drains were excluded from these counts. The pebble counts were organized into bins from $4 \mathrm{~mm}$ to $128 \mathrm{~mm}$ in half phi-scale increments (Krumbein, 1932). Nine counts of the larger (>=256 mm), structural boulders composing the constructed drain were performed by blindly selecting the direction to the next clast while standing within the drain. These boulder counts were binned into 256, 512, 1024, and $2048 \mathrm{~mm}$ classes. Four bulk samples of finer grain sediments were taken from within constructed drains to better parameterize grain size distribution used in the CL LEM. The dried samples were split into two equal weight subsamples placed in a series of sieves $(0.5 \mathrm{~mm}, 1 \mathrm{~mm}, 2 \mathrm{~mm}, 4 \mathrm{~mm}$, and $8 \mathrm{~mm})$. The sieves were put into a Ro-Tap sieve shaker for 15 minutes. The fraction remaining in each sieve was then measured on a digital scale to find the grain size distribution of the subsample.

Raw GPS data were post-processed using the free RTKLIB program (Takasu and Yasuda, 2009) using a Continuously Operation Reference Station in Pikeville, Kentucky, as a base-station to derive highly accurate (centimetric to decimetric) GPS points. Pikeville is $\sim 52 \mathrm{~km}$ from the field study areas. The recommended parameters used in post-processing were provided by the manufacturer of the GPS receiver (https://bad-elf.com/pages/post-processing-gnss-data-with-rtklib-introduction). These points were made 
into a shapefile for each valley fill catchment within ArcMap. This allowed for the comparison of observed features with DEM-derived products like slope and other DEM derivatives.

\section{LiDAR Data Observations}

Seven LiDAR datasets from West Virginia (Amherstdale, Birch River, Boone-Kanawha-Raleigh, Cannelton, Clay-Nicholas, Holden, and Wharton) and two LiDAR datasets from Kentucky (Floyd-Pike and Perry-Knott-Breathitt) were rendered to investigate if the erosional features seen in the field were widespread, provide input topography for the CL landscape evolution model, and to calculate catchment morphometrics like drainage density (Fig. 8). The Holden dataset includes the field study area. Table 2 shows the total area of each dataset, the area affected by MTR/VF, and the percentage of land affected by MTR/VF. MTR/VF affected areas were delineated manually on a LiDAR base. Care was taken not include land associated with legacy surface mining. Each dataset was manually examined using knowledge acquired in the field to assess the presence of erosional landforms (Roering et al., 2013). Landslides and gullies were of special interest, as geometrically designed mining reclamation landscapes have been observed to be prone to genesis of these landforms (Martin-Duque et al., 2010; Schor and Gray, 2007). The generation of these new datasets of erosional features can also serve future researchers should field access to MTR/VF become more widespread.

Manual classification of gullies on MTR/VF was performed on nine high-resolution LiDAR datasets, which covered $1410 \mathrm{~km}^{2}$ (Table 2). Manual classification from airborne LiDAR imagery has been used to observe gullies under forest canopy in South Carolina (James et al., 2007). Automatic classification of gully erosion (Evans and Lindsay, 2010; Castillo et al., 2011) was not undertaken due to the morphology of constructed drains on valley fills being like that of gullies. Gullies on the MTR/VF landscape are often associated with the outlet of a retention cell (Fig. 9) or can form on face of the valley fills or sideslopes (Fig. 10) (Reed and Kite, 2017). Enlarged drains were also considered to be gullies if an asymmetry between groin drains (Fig. 11) or dramatic incision was readily visible in the slopeshade, a LiDARderived slope raster made to look like a hillshade. The gullies were counted for each dataset while 
observing whether the gullies were associated with the drainage system, occurring upon a valley fill, associated with a road, or occurring along the periphery of the affected area but not associated with drainage system. The number of gullies per unit area was calculated by dividing the number of gullies by the total area affected by MTR/VF. Quantification of true gully density $\left(\mathrm{m} \mathrm{m}^{-2}\right)$ was not undertaken as the identified gullies often grade into the existing fluvial system, making it difficult to ascertain gully length. Gullies formed in landslide deposits associated with MTR/VF were not counted.

Manual delineation of landslides from airborne LiDAR imagery has been successful in forested environments (Eeckaut et al., 2007; Konsoer and Kite, 2014). Landslides in mountaintop removal affected areas within two datasets were manually delineated using LiDAR-derived slopeshades. Areas of heightened surface roughness (Fig. 12) and obvious head-scarps and deformation within valley fills were used as indicators of landsliding (Fig. 13) (Reed and Kite, 2017). Landslides not occurring directly within valley fills must "scallop" the edges of mountaintop removal landforms to be considered related to MTR/VF. Deposits covering roads below MTR/VF was used as another indicator (Fig. 14). Care was taken to ignore landslides associated with legacy (pre-SMCRA) contour mining that has caused many unstable slopes in these areas (Fig. 15) (Bell et al., 1989). The areal extent of the landslides $\left(\mathrm{km}^{2}\right)$ was mapped for two datasets, Amherstdale (WV) and Floyd-Pike (KY) by manually delineating supposed landslide scarps and deposits from LiDAR-derived slopeshades in ArcMap. Landslides occurring within valley fills were quantified for all datasets. Landslide head-scarps in valley fills were measured using the 3D Analyst Extension of ArcMap. Although field validation of the LiDAR data interpretations will be lacking, the landslide dataset could provide future researchers with useful information, if repeat LiDAR data are ever collected for the studied areas.

\section{Catchment Morphometrics}

Drainage density and catchment midpoints from both valley-filled and less disturbed catchments were compared in the Holden and Amherstdale LiDAR datasets. Valley-filled ( $\mathrm{n}=56)$ and less disturbed catchments with no evidence of anthropogenic valley fills $(n=57)$ were delineated from LiDAR-derived 
flow accumulation rasters using the D8 algorithm in ArcMap (O'Callaghan and Mark, 1984). The drainage density of constructed drains present upon reclaimed coal mining landforms is most likely an inadequate simulacrum of the location and number of natural channels present in an unmined catchment (Kite et al., 2003). The algorithm of Grieve et al. (2016a) was used to automatically extract channel networks in both mined and less disturbed catchments. The catchment DEMs were run through a Wiener filter (Wiener, 1949) using a 6-m moving window to smooth some of the topographic noise from the high-resolution LiDAR data. The DEMs were filled and subsequently the Dinfinity flow routing algorithm of Tarboton (1997) found the drainage area for each pixel. Any fluvially-incised valley must first cross a threshold of tangential (planform) curvature to eliminate convex or planar parts of a catchment less likely to be dominated by fluvial processes (Pelletier, 2013). The algorithm found this threshold, which represents the hillslope-channel transition, from quantile-quantile plots of tangential curvature for each catchment (Lashermes et al., 2007; Passalaqua et al., 2012). The drainage density of a catchment has been linked to erosion rate (Clubb et al., 2016), and anthropogenic disturbance such as road building can lead to unplanned increases in drainage density via the unnatural concentration of flow in steep areas (Montgomery, 1994).

Individual catchments were delineated from the LiDAR data by selecting a pixel representing the outlet of the catchment. This selected pixel was then converted into a vector point using ArcMap's "convert graphics to features". The resulting vector point data was used in ArcMap "Snap Pour Point" tool, which locates a pixel with the highest drainage area near the location of the vector point data. The pour points were used to fully delineate the drainage area of individual catchments using the "Watershed" tool. This resulted in a raster of catchment boundaries. The raster was converted into a polygon with the "Raster to Polygon" tool, and the LiDAR-derived DEM was then clipped to the polygon. The "Split Raster" tool was used to extract individual catchment DEMs. The DEMs were exported as TIFF files. The TIFF files were converted to ENVI Band Interleaved by Line (BIL) files with the Geospatial Data Abstraction Library translate utility for usage with the LSDTopoTools channel extraction tool 
(http://lsdtopotools.github.io), which runs the geometric channel extraction algorithm. This algorithm produced rasters of the stream networks that were used to calculate drainage density in ArcMap.

Catchments used in CL modeling were similarly run through this channel extraction process both before and after 1000 years of modeled erosion and deposition to see if drainage density changes occur over time.

Catchment midpoint areas were determined for all catchments by dividing the catchment drainage areas by two. The corresponding value was identified within each catchment manually from a reclassified flow accumulation raster showing only flow lines associated with drainage areas over $13,000 \mathrm{~m}^{2}$. This metric was thought to be important as drainage networks within valley-filled catchments can be very irregular with large upland drainage area accumulation zones (Fig. 16). The basin midpoint may be used to predict the locations of preferential erosion in valley-filled catchments, if large asymmetries in drainage area are present.

\section{Depression Storage Quantification}

Depression storage is the water retained in a catchment both during and after storms (Ullah and Dickinson, 1979). DEMs are a common way to estimate the size of macro-scale depressional features in catchments (Amoah et al., 2012), and high-resolution LiDAR-based DEMs have been used to quantify depression storage capacity in wetland settings (Maxa and Bolsad, 2009). MTR/VF can have substantial amounts of depression storage above steep slopes to attenuate stormflow response and sediment transport out of affected catchments (Fig. 17). Macro-scale depression storage capacity (mm) was quantified for valley-filled $(n=41)$ and less disturbed catchments $(n=59)$ by creating a raster of difference between a "pit-filled" DEM and the original DEM of the Holden and Amherstdale datasets using raster math in ArcMap (Amoah et al., 2012). By clipping this residual raster to the delineated valley-filled and less disturbed catchments, the depression storage volume was determined for each catchment as the sum of all residual elevations within it using the "Zonal Statistics as Table" function in ArcMap. The storage volumes were then compared to those of catchments not affected by MTR/VF. Valley-filled catchments 
with evidence of subsurface drain pipes, which block flow in DEMs, or on-going construction at the time of the LiDAR acquisition were purposely avoided in this analysis, as anomalously high volumes of depression storage can occur.

\section{CAESAR-Lisflood Landscape Evolution Modeling}

The CL landscape evolution model was used to explore possible landscape trajectories of MTR/VR affected catchments. This exploration is an initial effort based on limited data, but the model has been used to study post-mining landscapes before (Hancock and Coulthard, 2015). Landscape evolution modeling is a numerical modeling technique that acts to modify input topography with equations representing Earth surface processes (e.g., fluvial erosion) to produce output topography over a userdefined time period (Tucker and Hancock, 2010). Within CL, fluvial erosion, creep, and threshold slope landsliding processes are represented (Coulthard et al., 2013). An hourly rainfall record acts to produce runoff via TOPMODEL (Beven and Kirkby, 1979), and runoff flows are routed and distributed by modified shallow water equations (Bates et al., 2010). Variable timesteps based on flow or erosion allow for modeling of unsteady flows (Coulthard et al., 2013). Modeled flows erode and transport sediment using the Wilcock and Crowe (2003) framework, which uses the grain size distribution (GSD) at the surface for the basis of entrainment. Hourly rates of average discharge $\left(\mathrm{m}^{3} \mathrm{~s}^{-1}\right)$, sediment yield $\left(\mathrm{m}^{3} \mathrm{hr}^{-1}\right)$ are the model output. Rasters of median grain size, elevation, and elevation difference can also be recorded at user-defined intervals.

The model was driven by 62-year hourly rainfall rate $\left(\mathrm{mm} \mathrm{hr}^{-1}\right)$ record from Yeager Airport in Charleston, West Virginia (NOAA, 2015), that had been passed through a Neyman-Scott Rectangular Pulse (NSRP) model, a stochastic rainfall generator, to include large return interval events while keeping the statistics of the regional rainfall record intact (Fig. 18) (Cowpertwait et al., 1996). NSRP models use the statistical properties (e.g., 1 hour mean in a certain month) of the historic data to generate storm "cells" or pulses, which have a random duration and random intensity (Cowpertwait et al., 1996). The single-site rainfall generator used in Brocca et al. (2013) was run in MATLAB to produce ten 100-year datasets from the 
original 62-year dataset. These new 100-year rainfall records were pieced together to form a 1000-year record. CL has been used with a rainfall generator previously in Coulthard et al. (2012) to simulate climate change. Hancock et al. (2017) used generated rainfall records in CL to explore variability in sediment output from reclaimed uranium mines. The rainfall generator allows for high-intensity rainfall events not captured within the original rainfall record (Fig. 19). The mean annual rainfall for the generated 1000-year record was $1056 \mathrm{~mm}$, which is lower than the annual mean of $1089 \mathrm{~mm}$ for the 62 year record for Yeager Airport. Figure 20 shows a plot of annual rainfall for 1000-years from the generated dataset.

The input topography supplied to the model was $1 \mathrm{~m} \mathrm{LiDAR-derived} \mathrm{DEMs} \mathrm{of} \mathrm{valley-filled} \mathrm{catchments.}$ Five catchments were selected to provide a representative sample of MTR/VF morphology (Figs. 21-25). Three groin-drain and two center-drain valley fills were selected. Table 3 has the location, drainage area, dataset, and other notes pertaining to DEM rotation, presence of a bedrock DEM, and drainage area modifications. Several catchments required additional preparatory steps before modeling, such as cropping away parts of the DEM, which extended beyond the outlet (e.g., the lowest value in the DEM) in the coordinate space of the DEM for proper drainage within the model. Drainage area modifications were performed via a CL utility called DEM editor. Many valley-filled catchments exhibit highly unnatural shapes with large zones of drainage area accumulation residing above the steep side slopes, so some minor alteration ( $<100$ pixels) of DEMs was generally unavoidable. Drainage area reduction was minimized by rotation of the DEM in 45-degree increments. Rotation of the DEMs was accomplished within ArcMap using the "Rotate" function.

CL allows modeling an unerodable bedrock under a layer of regolith as a separate DEM (Van de Wiel et al., 2007). Bedrock was included in three modeled catchments (BKR \#1, Scarlet \#1, and Whitman \#8) 2 $\mathrm{m}$ below the surface of input topography in areas considered colluvial side-slopes to simulate a $2 \mathrm{~m}$ thick soil. This depth coincides with the described general depth of the Highsplint soil series, a channery loam with around 15-35\% rock fragments (Pate, 2008). Bedrock DEMs were created by manually delineating 
areas considered to be colluvial slopes from LiDAR-derived slopeshades using ArcMap with the aid of Google Earth imagery. The original DEM of input topography was then clipped to the bedrock zone polygon. This raster grid then was reduced in elevation by $2 \mathrm{~m}$ using raster math in ArcMap. Another polygon with the bedrock zones removed from a polygon of the entire watershed was created with the "Erase" function in ArcMap. The original topography was then clipped to the resultant polygon. This DEM was then reduced in elevation by $100 \mathrm{~m}$ (an arbitrarily high value) to simulate an insurmountably large depth to bedrock in order to have congruent dimensions among the surface and bedrock DEMs. The final bedrock DEM was then created by mosaicking the reduced DEM and the original DEM with the bedrock zones removed.

Valley fills are composed of a diverse range of grain sizes with the distribution primarily controlled by the fragmentation of rock by explosives (Daniels and Zipper, 2010). Sand and finer sediments $(<=2 \mathrm{~mm})$ can be 10 to $25 \%$ of total fill volume (Daniel and Zippers, 2010). Geophysical measurements of electrical resistivity on a valley fill in Virginia showed that grain size increased with depth (Greer et al., 2017). Sampling the full GSD of valley fill posed a challenge for this study as destructive trenching and digging were not permitted in the study area. The upper $2 \mathrm{~m}$ (10 layers of $0.2 \mathrm{~m})$ of the surface that the model operates upon can be divided into up to five distinct zones with unique GSDs. After $2 \mathrm{~m}$, the model reverts to the default GSD supplied to model (Van de Wiel et al., 2007). A polygon of grain size zones was created by first delineating the watershed into colluvial slopes, areas with mine soil at the surface, and constructed drains. The polygon objects were coded with a number corresponding to grain size zone. The polygon was then turned into a raster using the "Polygon to Raster" function in ArcMap using the code to populate raster values (Figs. 26-30). This new grain zone raster was then used by the grainfilemaker program included with CL to create a special raster-like file that has a user-supplied GSDs corresponding to the grain zone raster value. The nine grain sizes that were used CL are $0.5 \mathrm{~mm}, 1 \mathrm{~mm}, 4$ $\mathrm{mm}, 8 \mathrm{~mm}, 32 \mathrm{~mm}, 64 \mathrm{~mm}, 256 \mathrm{~mm}, 512 \mathrm{~mm}$ and $2048 \mathrm{~mm}$. These bins attempted to capture the diversity grain sizes present in the valley fill. The grainfilemaker program can only change GSDs for the 
different zones not the sizes of the grains, so the selected nine grain sizes was used to model all grain size zones.

Parameterization of the GSDs used in the modeling runs was arrived at via several methods. A general GSD of mine spoil from a mining engineering technique used in Jackson (2015) served a base for the GSD. Jackson (2015) used a set of empirical equations, which accounted for blasting parameters and rock strength (Cunningham, 1987), to predict an optimal GSD for hauling Central Appalachian basin sandstone fragments from a contour mine. A $5^{\text {th }}$ order polynomial curve was fit to the reported values of Jackson (2015) to obtain the proportion of the distribution for the grain sizes used in the CL modeling runs. This technique does not account the fine fraction very well (Ouchterlony et al., 2017), so the estimate of $25 \%$ soil size particles $(<=2 \mathrm{~mm})$ in valley fills by Daniels and Zipper (2010) was used to help constrain the 0.5 and $1 \mathrm{~mm}$ grain size classes. The $0.5 \mathrm{~mm}$ and $1 \mathrm{~mm}$ grain size classes were further constrained by the four samples of finer sediments retrieved from around the outlet of valley fill drains. In the samples, the $0.5 \mathrm{~mm}$ and below fraction was seen to be $79.5 \%$ of the total weight on average. As such, $79.5 \%$ of the estimated $25 \%$ soil sized fraction was allotted to the $0.5 \mathrm{~mm}$ grain size in the GSD used in the modeling runs. The remaining $20.5 \%$ of the estimated soil sized fraction was allotted to the $1 \mathrm{~mm}$ grain size. The remaining grain sizes used in the modeling runs $(4 \mathrm{~mm}, 8 \mathrm{~mm}, 32 \mathrm{~mm}, 64 \mathrm{~mm}, 256 \mathrm{~mm}$, $512 \mathrm{~mm}$, and $2048 \mathrm{~mm}$ ) were parameterized from the distribution of Jackson (2015) to yield a "base" GSD that occurred $2 \mathrm{~m}$ below the mine soil and constructed drain grain zones (Table 4). The GSD in the constructed drain was based on the field observation that boulders ( $>=256 \mathrm{~mm}$ ) comprise $\sim 80 \%$ of the clasts within the constructed drains (Fig. 31). This observation and the nine boulder counts described previously parameterized the $256 \mathrm{~mm}, 512 \mathrm{~mm}$, and $2048 \mathrm{~mm}$ grain size fractions for the constructed drain grain zone. The remaining $20 \%$ of the constructed drain GSD was generated from the "base" GSD (Table 4). The mine soil grain zone was based on the properties of the FiveBlock soil series, which is a common soil on reclaimed MTR/VF landscapes (Pate, 2008). The soil texture is described as a very channery sandy loam with around $65 \%$ or more rock fragments $(>2 \mathrm{~mm})$. The $0.5 \mathrm{~mm}$ and $1 \mathrm{~mm}$ grain 
sizes were apportioned $35 \%$ of the total distribution based on the average rock fragment percentage in the FiveBlock series (Pate, 2008). This reduced 10\% from all other grain size proportions. As the soil is described as very channery $(2-150 \mathrm{~mm})$, the proportions assigned to the $4 \mathrm{~mm}, 8 \mathrm{~mm}, 32 \mathrm{~mm}$, and $64 \mathrm{~mm}$ were multiplied by 2 to comport with the formula that determines the texture modifier very channery. The $2048 \mathrm{~mm}$ grain size was assigned 0\%, as the general description of Fiveblock does not mention boulder size fragments (>=600 mm) (Pate, 2008). The "base" GSD determined the remaining proportion assigned to $256 \mathrm{~mm}$ and $512 \mathrm{~mm}$. The colluvial side slope GSD was based on the Highsplint soil series, which is common on steep slopes in the area (Pate, 2008). The $0.5 \mathrm{~mm}$ and $1 \mathrm{~mm}$ grain sizes were assigned $65 \%$ of the distribution based on the soil series description from the Mingo-Logan county soil survey (Pate 2008). The remainder of the distribution was apportioned to the $4 \mathrm{~mm}, 8 \mathrm{~mm}, 32 \mathrm{~mm}, 64 \mathrm{~mm}$, and $256 \mathrm{~mm}$ grain sizes roughly based on the more detailed particle size distributions available from the National Cooperative Soil Survey Soil Characterization Database (https://ncsslabdatamart.sc.egov.usda.gov). The $512 \mathrm{~mm}$ and $2048 \mathrm{~mm}$ grain sizes were assigned $0 \%$ as the soil description does not mention stones or boulders (Pate, 2008) (Table 4).

Unit discharge from the outlet of catchment Whitman \#9 was calibrated to high-resolution discharge and precipitation data from a $0.68 \mathrm{~km}^{2}$ valley-filled catchment located in Boone County, West Virginia (Nippgen et al., 2017), to arrive at a value for the $m$ parameter value used in the TOPMODEL-based hydrological sub-model (Beven and Kirkby, 1979). The $m$ value controls how rapidly runoff is generated in a catchment, with low values representing more "flashy" catchments (Beven et al., 1995). A value of 0.007 was used for all modeling runs outside the sensitivity analysis, as it was seen to more appropriately represent storm responses in valley-filled catchments relative to values of 0.005 and 0.009 (Fig. 32).

The slope of stream below the outlet of the modeled catchment must be parameterized for proper sediment transport. The post-outlet slope was obtained from a LiDAR-derived DEM with the 3D Analyst extension of ArcMap. The "Interpolate Line" function was used to create a line from 30-50 m along the 
outlet stream. This line was visualized with the "Profile Graph" function to determine outlet slopes from elevation change along the line, which ranged from 0.10 to 0.16 (Table 3 ).

The default CL threshold slope of $45^{\circ}$, was used in all model runs. Above $45^{\circ}$, slopes fail until a value of $45^{\circ}$ or less is reached (Coulthard et al., 2002). A threshold slope of $45^{\circ}$ was determined to be optimal by generating 1000 points within Whitman \#9 catchment then retrieving the slope values for the points. The histogram of the points allowed determination of the steepest slopes maintained in the catchment, as a break in the values occurs between the threshold and very high values taken to be rock outcrops. The usage of $45^{\circ}$ showed minimal mass wasting upon initiation of the model, which comported with the state of the catchments as viewed in the LiDAR data.

Soil creep is modeled in CL as having a linear dependence on slope (Coulthard et al., 2013). The diffusion-like process of soil creep acts to fill in depressions and round off landscape roughness elements (Smith and Bretherton, 1972). A value of $2.5 \mathrm{~mm} \mathrm{yr}^{-1}$ is the default CL value, a value close to the $2 \mathrm{~mm}$ $\mathrm{yr}^{-1}$ creep rate in the Susquehanna Shale Hills Critical Zone Observatory determined via cosmogenic radionuclides (West et al., 2013), and was used for all model runs.

A simulated vegetational cover is included in CL (Hancock et al., 2015). This allows for a bi-stable landscape, where erosion rates are low if vegetation is intact (Howard, 1999). Once the vegetation is stripped by a large runoff event, erosion rates can increase on exposed ground (Howard, 1999). A value of $40 \mathrm{~Pa}$ is used as a "vegetation critical shear stress" in all modeling runs except for the sensitivity analysis. This value was used as modeled vegetation unrealistically grew in all parts of the catchment if higher values were used. Field observations showed small fluvial channels within constructed drains near the toe of the valley fills which lacked intact vegetation except for moss on rocks (Fig. 33). If modeled vegetation exists at a pixel, then the erosion rate determined by the sediment transport model is reduced by $90 \%$. Once vegetation has been stripped away, five model years pass before the modeled vegetation regains its protective capacity (Hancock et al., 2015). 
The flow model of CL is based on Lisflood-FP shallow water equations code (Bates et al., 2010), and requires several parameters that are constrained by literature or scaled to the resolution or size of the input DEM. CL allows for an average daily evaporation, so erroneously high discharges do not occur at the catchment outlet (Coulthard et al., 2013). Based on the runoff ratio of 0.51 for a first-order valley-filled catchment in Boone County, West Virginia (Nippgen et al., 2017), a steady evaporation rate of $1.446 \mathrm{~mm}$ day $^{-1}$ was imposed upon the modeled catchments, so that $\sim 50 \%$ of precipitation evaporated. To speed the operation of the flow model, a threshold depth of $0.01 \mathrm{~m}$ was used to calculate flow depth, which is passed on to the sediment transport model. As per the recommendation of the model designer (Skinner and Coulthard, 2017), the threshold depth is $1 / 100^{\text {th }}$ of the DEM resolution (i.e., a $50 \mathrm{~m}$ DEM would use $0.5 \mathrm{~m})$. An "input-output" difference parameter $\left(\mathrm{m}^{3} \mathrm{~s}^{-1}\right)$ allows the model to switch to longer timesteps when the model is near a steady-state input-output balance; an "input-output" difference of $0.1 \mathrm{~m}^{3} \mathrm{~s}^{-1}$ was selected. This value was a compromise between long model run times and the model designer's recommendation to select a value close to mean annual flow. Mean annual flow of $0.014 \mathrm{~m}^{3} \mathrm{~s}^{-1}$ from a $0.68 \mathrm{~km}^{2}$ valley-filled catchment reported by Nippgen et al. (2017) is so low as to require extremely long model run times. A Manning's $n$ roughness coefficient of 0.06 was selected to simulate the cobble/boulder constructed drain (Chow, 1959). Manning's $n$ is used to calculate flow velocities for discharge calculation and flow routing.

The five modeled catchments varied in drainage area from 18.5 ha to 37.8 ha. Modeling larger valleyfilled catchments, which generally have more depression storage capacity, was hindered by the "inputoutput" difference parameter, as larger values would be needed to complete model runs in a timely manner. Three groin-drain and two center-drain valley fills were modeled for 1000 years under three different GSDs, because GSD was considered to be the parameter with the most uncertainty and variability, as it is partially a function of human decision making. GSDs were coarsened or fined following the method of Skinner et al. (2017). The GSDs in CL are composed of nine grain sizes. The proportions of the finest five grain sizes $(0.5,1,4,8$, and $32 \mathrm{~mm})$ were increased by $30 \%$, and the 
proportions of the four coarsest grain sizes $(64,256,512$, and $2048 \mathrm{~mm})$ were reduced by $30 \%$ to create a finer GSD for all four grain size zones. The opposite was done to create coarser GSDs. The new proportions were then normalized to sum to 1.0 based on the relative values of each grain size (Fig. 34). Slope of the catchment outlet was the only user-defined model parameter to vary between modeled catchments.

A one-factor-at-a-time (OAT) sensitivity analysis (Saltelli and Annoni, 2010) was performed for three parameters for the Whitman $\# 8$ catchment. Vegetation critical shear stress was varied $\pm 10 \mathrm{~Pa}$ relative to the reference value of $40 \mathrm{~Pa}$, and the TOPMODEL $m$ parameter was varied \pm 0.002 relative to the reference value of 0.007 . Manning's $n$ was varied by \pm 0.02 relative to the reference value of 0.06 . These parameters have been shown to affect sediment yield in CL (Skinner et al., 2017). A $m$ value of 0.005 has been used in CL to represent grassland vegetation in Coulthard and Van der Viel (2017). A $m$ value of 0.009 could represent a more forested scenario. Vegetational critical shear stress has only been measured in flume studies (Prosser and Slade, 1994; Prosser and Dietrich, 1995). In studies utilizing CL, vegetational critical shear stress values range from 7-300 Pa (Skinner, 2017; Hancock et al., 2015; Zilliani et al., 2013). Sediment yield $\left(\mathrm{m}^{3} \mathrm{hr}^{-1}\right)$ and DEMs of difference (DoDs) will provide metrics of comparison between the modeling runs.

\section{Results}

\section{Field Work Observations}

Gullies were present on the sideslopes and faces of some valley fills. Three main gully initiation mechanisms occurred: overtopping of stormwater retention cells (known henceforth "retention cells"), intentional discharges from retention cells onto colluvial sideslopes, and flow between terraces outside the constructed drainage system. Erosional features interpreted to be induced by seepage erosion, and features associated with fluvial erosion around the constructed drain were also present.

Overtopping or breaching of a retention cell margin led to the erosion of a $3.2 \mathrm{~m}$ wide and $1.1 \mathrm{~m}$ deep gully on a colluvial sideslope in the EIP \#5 catchment. The gully channel could be seen in the LiDAR 
data, which was flown in late 2010/early 2011, and live vegetation and leaf litter were present within the channel during field work (Fig. 35). The gully extends $\sim 30 \mathrm{~m}$ from a retention cell located at the top of the colluvial sideslope to a portion of the slope that has failed and filled a section of the gully (Fig. 36). The gully can again be seen below the failed section, where it intersects the face of the valley fill. EIP \#5 is a center-drain style fill, hence the gully eroded a farther $\sim 38 \mathrm{~m}$ into the unprotected interface of the valley fill face and the colluvial sideslope. In the field, the retention cell showed no erosion above the gully, indicating the cell either had been repaired or was overtopped with no noticeable erosion. A retention cell was observed to have failed along an overgrown access road in upper reaches of the Whitman \#9 catchment. The cell failure induced a debris flow that eroded into colluvium on the slope and deposited sediments on a topographic bench (Fig. 37). The $\sim 2 \mathrm{~m}$ wide debris flow track had cobble levees, poorly sorted sediments, and terminated in a lobate deposit, which are indicative of a debris flow (Major, 1997). This feature was not seen the LiDAR data, indicating that the debris flow occurred after early 2011.

The intentional routing of water from of a group of connected rentention cells was inferred to cause two gullies to form upon a colluvial sideslope in the Whitman \#12 catchment (Fig. 38). At the widest section, the larger gully was $\sim 5 \mathrm{~m}$ wide and $\sim 1.5 \mathrm{~m}$ deep. No bedrock was observed along the bed of either gully. The larger of the two gullies had two heads. The larger gully extended $\sim 74 \mathrm{~m}$ down the sideslope from its head, which was $\sim 35 \mathrm{~m}$ below the retention cells, according to the LiDAR data (Fig. 39). Poor GPS coverage due to topography and tree cover did not allow comparison of the existing gully head to the position indicated by LiDAR data. The larger gully ended above the former location of the sediment retention pond, which has since been removed. The smaller gully initiated $\sim 40 \mathrm{~m}$ below the heads of the larger gully and ran subparallel to the larger gully, (Fig. 39). This gully ended in a landslide scar located just above the the valley toe. Intentional discharge from an overflow standpipe outlet on a large retention cell eroded into a slope within the Whitman \#16 catchment (Fig. 40). The gully extended $\sim 105 \mathrm{~m}$ downslope from an access road to the edge of the valley fill; and from there extended a farther $\sim 115 \mathrm{~m}$ 
along the sideslope-valley fill interface (Fig. 41). LiDAR data observations described later will show that erosion due to retention cell interactions was widespread in areas affected by mountaintop removal coal mining (Section 3.2.1).

Several gullies were found on the faces of valley fills. These gullies were inferred to occur from water flowing over the edge of a valley fill terrace. In Whitman \#8, a $1.1 \mathrm{~m}$ deep by $2.6 \mathrm{~m}$ wide (at the largest cross section) gully occurred for $27 \mathrm{~m}$ between two terraces (Fig. 42). The source of the runoff that incised the gully was most likely a small wetland on the upper terrace (Fig. 43). Living, pronated grass above the gully head indicated that a flowpath to the gully was still active (Wilson et al., 2003). This gully was present in the 2010-2011 LiDAR, but a GPS point taken above the present-day gully head shows that it may have extended $8 \mathrm{~m}$ farther by 2017. A small fan composed of sand and cobble-sized sediments occurred at the terminus of the gully on the lower terrace. This mechanism initiated smaller gullies at two other locations on Whitman \#8, and both were associated with retention ponding on the upper terrace. Whitman \#8 also contained a slope between two terraces with 11 small gullies, averaging $20 \mathrm{~cm}$ deep and $30 \mathrm{~cm}$ wide, in a grove of planted pine trees, which had suppressed other ground cover (Fig. 44). The gullies were filled with duff in 2017 and did not appear to be active flowpaths. In EIP Copperas \#3, a discontinuous gully occurred in fine sediment derived from deeply weathered black shale on the slope between two terraces (Fig. 45). Small gullies were also found along the interface of valley face and colluvial sideslope in three other valley-filled catchments. A $4.5 \mathrm{~m}$ long gully with a maximum crosssectional area of $0.4 \mathrm{~m}^{2}$ occurred in Whitman \#18 where water is routed off the edge of the terrace to the constructed groin drain (Fig. 46).

Erosion induced by seepage from the subsurface occurred in several catchments. The largest example of subsurface erosion was in Whitman \#8 (Fig. 47). The feature possessed no visible flowpath above it and an arcuate scarp, which was $\sim 2.6 \mathrm{~m}$ wide and $\sim 1.1 \mathrm{~m}$ deep. Although this feature was seen in the 20102011 LiDAR data, there was little vegetation in 2017, indicating active erosion or adverse hydrological conditions for revegetation (Dunne, 1990). The feature is located above a non-designed spring-fed step- 
pool channel running down the center of the toe of valley fill (Fig. 48). A circular depression with a diameter of $\sim 1 \mathrm{~m}$ and a depth of $\sim 0.5 \mathrm{~m}$ was directly in front of the large seepage feature and above the stream (Fig. 49). Three small seepage features were observed in the EIP \#4 catchment (Fig. 50). The seeps were located between two terraces high on the valley fill face, a surface not subject to mitigation that altered parts of this valley fill. These seeps were closely positioned and were actively discharging water at the time of observation. These seeps may be soil-pipe outlets (Wilson et al., 2008). Whitman \#15 also showed some signs of subsurface-induced erosion with a small gully, measuring $\sim 0.5 \mathrm{~m}$ deep and $\sim 0.5 \mathrm{~m}$ wide at the head scarp, with no observed flowpath above the gully head scarp (Fig. 51). This catchment had evidence of large soil macropores in the mine soil (Fig. 52). Mine soil macropores were observed in EIP \#1, EIP \#2, EIP \#3, and Whitman \#19. Small-scale subsidence features and holes exposing an open boulder framework were observed within the toes of several valley fills. Eight depressions or holes, ranging in depth from 0.5-1.1 $\mathrm{m}$ and in width from 0.5-2.2 $\mathrm{m}$, were present on the soil-mantled valley fill toe of Whitman \#7, and were interpreted to be caused by subsurface winnowing of finer sediments, inducing subsidence, as most valley fills toes did not display an open framework (Fig. 53). Finer sediments were seen to be preferentially eroded away from toe sediments along the banks of fluvial channels present in most designed drains in catchments EIP \#1 and Whitman \#11 (Fig. 54). The fluvial channels may locally erode into colluvial slopes that intersect the toes of valley fills, as observed in Whitman \#14, \#17, and \#19 (Fig. 55).

Small landslides associated with former sediment retention ponds, all-terrain vehicle tracks, and patches of bare ground were observed on valley fills. The landslides were associated with former sediment retention ponds that were removed upon full reclamation. Sometime after excavation and reclamation of the sediment pond, steep sideslopes failed in EIP \#2, EIP \#4, Whitman \#12, and Whitman \#13 (Fig. 56). No landslide was seen to directly supply sediment to a stream coming out of the valley-filled catchment. Small landslides occurred along the interfaces of valley fill face and colluvial sideslope in two catchments, Whitman \#16 and Whitman \#20. All-terrain vehicle tracks were present on two valley fills 
faces. A track on EIP \#1 extended from the top of the valley fill face to the toe (Fig. 57). The sediments in the wheel ruts of the track were cobble-sized, a possible indication that fine sediments have been removed by fluvial reworking. Another track on Whitman \#21 extended 120 m down the valley fill face, and sediments within it showed signs similar fluvial winnowing. Bare patches of ground on a valley fill were seen on the faces of several fills. The bare patches were associated with highly weathered shale or siltstone clasts at the surface (Fig. 58). The bare ground patches are most likely not producing a fertile soil from the available parent material (McFee et al., 1981).

Two studied valley fills, Whitman \#9 and Whitman \#16, were observed to be predominatly composed of fine material associated with the processing of coal (Stewart and Daniels, 1992). The material was mostly coal, shale, and sandstone; the coal and shale gave the material a black color (Fig. 59). Whitman \#9 showed dramatic erosion within the valley fill face and groin drains (Fig. 60). Both groin drains were eroded to underlying bedrock in sections. The erosion had caused the development of a $\sim 3 \mathrm{~m}$ high bedrock knickpoint in the north groin drain (Fig. 61). Both groins had enlarged into gullies, which was a widespread condition in the regional LiDAR data observations (Section 3.2.1). The maximum dimensions of the south groin drain were $\sim 9 \mathrm{~m}$ deep and $\sim 20 \mathrm{~m}$ wide at a location noted in Figure 60 . An indicator of the depth of erosion in the south drain was a fence suspended $\sim 6 \mathrm{~m}$ in the air across the width of the gully. Two gullies such as one in the Whitman \#18 catchment, which eroded into the edge of the terrace beside the groin drain, were also observed in Whitman \#9, but were much larger. A pipe from a sediment cell across the haul road at the top of the Whitman \#16 fill discharged water directly into the center drain (Fig. 62). The center drain was extremely deep and wide farther down the face with maximum dimensions of $\sim 8 \mathrm{~m}$ deep and $\sim 28 \mathrm{~m}$ wide (Fig. 63). This apparent enlargement occurred despite the presence of many large boulders still lining the drain.

The 13 pebble counts from fluvial channels developed in constructed drains had an average median grain size $\left(\mathrm{D}_{50}\right)$ of $16 \mathrm{~mm}$ (coarse gravel) and were poorly sorted. The $\mathrm{D}_{50}$ ranged from 12 to $24 \mathrm{~mm}$. A cumulative grain size distribution plot for Whitman \#18 is shown in Figure 64. Table 5 shows the $\mathrm{D}_{50}$, 
sorting, and sediment name using the system of Folk and Ward (1955). The highest $\mathrm{D}_{50}(24 \mathrm{~mm})$ occurred in a valley fill that was freshly mitigated, EIP \#4. Although the pebble count for EIP \#4 was performed in an unmitigated lower section of a constructed drain, the section above had been reconfigured to resemble a step-pool channel, which may have skewed the count to a coarser $\mathrm{D}_{50}$. Nine boulder counts within constructed drains showed the dominant $256 \mathrm{~mm}$ to $512 \mathrm{~mm}$ fraction made up an average of $47 \%$ of total clasts. Boulders over $2048 \mathrm{~mm}$ averaged only $1.5 \%$ of all clasts. An example grain size distribution from the boulder count from Whitman \#8 is shown in Figure 65. Bulk samples of fine sediments from fluvial channels within constructed drains averaged $79.5 \%$ finer than $0.5 \mathrm{~mm}$. Further particle size analysis of bulk samples was not undertaken due to a limited number of grain sizes allowed in the CL landscape evolution model.

\section{LiDAR Data Observations of Erosional Landforms}

\section{Gullies}

Gullies were observed in all LiDAR datasets. Across the 9 datasets, 991 manually classified gullies occurred across $375 \mathrm{~km}^{2}$ of MTR/VF affected land. Gullies were associated predominantly with retention cells and diversion ditches located on the periphery of land affected by MTR/VF, constituting an average of $53.5 \pm 10.9$ percent of total gullies at individual sites (Fig. 66). Table 6 shows the percentage for each class for all datasets. Gullies associated with roads and gullies occurring on the periphery of mined lands with no interaction with the valley fill drainage system averaged $15.2 \pm 6.4$ and $14.6 \pm 6.2$ percent, respectively. Valley fill face and backfill associated gullies were the least abundant.

The Perry-Knott-Breathitt dataset contains the greatest number gullies, 349, and most gullies per km², 5.0 (Fig. 67). A clear trend in gullies per $\mathrm{km}^{2}$ occurred within the datasets; more gullies per $\mathrm{km}^{2}$ are observed as one moves southwest from West Virginia towards east-central Kentucky where the Perry-KnottBreathitt dataset is located (Fig. 68). The Cannelton, West Virginia, dataset does not follow this trend, possibly because it contains the oldest valley fills in all the West Virginia datasets, with many valley fills 
from 1984 and 1990 (Fig. 69). As valley fill construction methods have changed through time (Michael and Superfesky, 2010), the age of a MTR/VF landscape can determine both the construction methods employed and the amount of exposure to erosion-inducing storm events. Cannelton shows an elevated percentage of gullies occurring as enlarged constructed drains and sideslope gullies not associated with the drainage system. The two Kentucky datasets, Perry-Knott-Breathitt and Floyd-Pike, both show higher percentages of gullies occurring within valley fill faces or backfill material with 24.9 percent and 12.3 percent, respectively.

\section{Landslides}

The Floyd-Pike (KY) dataset exhibited more and larger landslides than the Amherstdale (WV) dataset. The Amherstdale dataset contained 15 landslides over $51.63 \mathrm{~km}^{2}$ of MTR/VF land while the Floyd-Pike dataset contained 125 landslides over $32.06 \mathrm{~km}^{2}$. The mean total area disturbed by landslides (scar and deposit) in the Floyd-Pike dataset was $14,614 \pm 19,047 \mathrm{~m}^{2}$ while mean size in the Amherstdale dataset was $9,791 \pm 14,317 \mathrm{~m}^{2}$. There were many gullies within landslide deposits that were not included in the quantification of gully erosion (Fig. 70). Figure 71 shows the widespread mass wasting in the Floyd-Pike dataset. The Floyd-Pike dataset also had 13 landslides (Fig. 72 and Fig. 73) within valley fill faces, while Amherstdale had only two, despite its larger area. The arcuate head scarps and downslope slope convexities exhibited by five of the landslides in the Floyd-Pike dataset suggested rotational movement (Highland and Bobrowsky, 2008). The largest main scarp was $\sim 13 \mathrm{~m}$ in height and $\sim 126 \mathrm{~m}$ from flank to flank (Fig. 74). The other six West Virginia datasets contained only one other landslide in the face of a valley fill, which was in the Boone-Kanawha-Raleigh dataset. Perry-Knott-Breathitt dataset from Kentucky contained three small landslides and one large landslide located within valley fill faces. The large landslide involves a near complete reorganization of the constructed topography of the valley fill face (Fig. 75). This landslide occurred on a valley fill that has been fully released from its reclamation bond and will not be provided maintenance in perpetuity (checked via https://eppcgis.ky.gov/smis).

\section{Drainage Density and Catchment Midpoints}




\section{Drainage Density}

The automated channel extraction using the geometric algorithm of Grieve et al. (2016a) revealed that drainage density in valley-filled catchments was lower than in catchments without valley fills in the Holden and Amherstdale datasets. Examples of the extracted channel network for a valley-filled and a less disturbed catchment are shown in Figures 76 and 77, respectively. Drainage density averaged $4.25 \pm$ $0.78 \mathrm{~km}^{-1}$ in the catchments with no valley fills $(\mathrm{n}=57)$ and $2.82 \pm 1.03 \mathrm{~km}^{-1}$ in valley-filled catchments $(n=56)$. Figure 78 shows that valley-filled catchments with low drainage areas have lower drainage densities relative to less disturbed catchments. A Welch's t-test showed that the two means are significantly different $(\mathrm{t}=-8.25, \mathrm{p}=<0.001)$. The filling of depressions that halt the immediate downslope flow of water in the initial catchment DEM by the algorithm caused it to overestimate the length of the channel network by connecting depressions in some valley-filled catchments (Fig. 79). This overestimation increased drainage density. Drainage density changes arising from CAESAR-Lisflood landscape evolution modeling will be covered later.

\section{Catchment Midpoints}

Reflecting their extensively rearranged topography and drainage network, valley-filled catchments have average catchment midpoints that occur higher in elevation relative to the outlet of the catchment when compared to more natural catchments (Fig. 80). Less disturbed catchments $(\mathrm{n}=57)$ averaged $48.9 \pm 22.5 \mathrm{~m}$ of relief between the midpoint and the outlet while valley-filled catchments $(n=56)$ averaged $73.9 \pm 47.4$ m (Fig. 81). The large standard deviation in midpoints relief for valley-filled catchments was due to the occurrence of some highly symmetric groin-drain style valley fills, which have two similarly sized channels that can lead to a drainage midpoint at their confluence, providing low catchment midpoint relief values (Fig. 82). These symmetric catchments contrasted sharply with asymmetric fills, which have high relief between the midpoint and the outlet, accumulating much of the drainage area above the constructed drains. Both the largest value of midpoint relief, $235.2 \mathrm{~m}$, and the lowest value, $0.2 \mathrm{~m}$, were calculated for 
groin-drain style valley-filled catchments in the Amherstdale dataset, indicating that groin-style valley fills can either be highly symmetric or asymmetric.

\section{Depression Storage Capacity}

Valley-filled catchments showed very high macro-scale depression storage capacity relative to less disturbed catchments (Fig. 83). This high storage capacity is a result of sediment cells and other constructed depressions in valley-filled catchments (Fig. 84). There was a substantial difference between the average depression storage capacity between the valley-filled catchments of the Holden and Amherstdale datasets. Valley-filled catchments from the Amherstdale dataset $(n=21)$ averaged $17.7 \pm$ $16.8 \mathrm{~mm}$ while those from the Holden dataset $(\mathrm{n}=24)$ averaged $8.0 \pm 6.1 \mathrm{~mm}$. The MTR/VF landscape of Amherstdale had larger and more abundant sediment cells relative to Holden (Fig. 85), which emphasized that construction methods can have considerable influence on depression storage capacity. Less disturbed catchments averaged much lower capacity in both the Amherstdale $(n=25)$ and Holden $(n=34)$ datasets, $0.2 \pm 0.1 \mathrm{~mm}$ and $0.1 \pm 0.2 \mathrm{~mm}$, respectively. Some of the higher values of valley-filled catchment depression storage capacity (e.g., above $10 \mathrm{~mm}$ ) were more analogous values reported for shallowly sloped headwater catchments in the coastal plains of South Carolina (Amoah et al., 2012). A Welch's ttest demonstrated that the mean depression storage capacity of valley-filled catchments was significantly different to the mean of natural catchments $(\mathrm{t}=6.31, \mathrm{p}=<0.001)$.

\section{CAESAR-Lisflood Landscape Evolution Modeling}

Five catchments were modeled for 1000 years under three different grain size distribution scenarios (reference, finer, coarser) using a 1000-year hourly rainfall record based on the historical Charleston, West Virginia, record as a driving force. DEMs of difference (DoDs) that were created by subtracting the DEM of initial topography for the catchment from the DEM of the model's output topography were used to compare the different scenarios for each catchment. Sediment yield from each run was used to compare each run and to calculate erosion rates, which was used to compare between catchments (see Section 4.4). 


\section{Whitman \#20}

Table 7 summarizes results from Whitman \#20 model runs. Modeled erosion on the Whitman West \#20 catchment was most pervasive on the toe of the valley fill, as shown by a DoD between the 1000 -year reference run and the original DEM (Fig. 86). In the reference run of the model, a large ( 4 $\mathrm{m}$ deep, $\sim 12$ $\mathrm{m}$ wide in some sections) gully eroded from the middle of the valley fill face to the toe of the valley fill. Another gully eroded into the colluvial sideslope via overtopping of a sediment cell. The unnaturally sharp edges of terraces, center drain, and sediment cells were rounded over time by modeled soil creep, generally decreasing in elevation by $0.5 \mathrm{~m}$ or more (Fig. 86). The bases of the slopes between terraces were sites of deposition with increases in elevation of $0.5 \mathrm{~m}$ in most cases. The center drain of this catchment exhibited significant deposition in the form of small alluvial fans that began within the drain then spread out upon the flat ground of the terraces. The center drain of this valley fill mimics the topography of the terraces, which may explain the modeled development of fans. In all model runs, the toe of the valley fill also developed a deep fan with up to $4.5 \mathrm{~m}$ of deposition near the outlet of the catchment (Fig. 86). The finer grain size model run showed development of a similar gully on the valley fill face that was closer to the constructed drain relative to the reference run (Fig. 87). The modeled gully on the colluvial sideslope emanating from the sediment cell was larger in the finer grain size run and eroded more heavily into the interface of the valley fill face and sideslope. The gullies that developed in the coarser grain size model run were smaller in both width and depth and occurred closer to the sideslope relative to the two other runs (Fig. 88). The alluvial fans along the constructed drain were also noticeable smaller in size in the coarser run.

In the reference run, net erosion of $24,011 \mathrm{~m}^{3}$ was modeled within the catchment. Modelled net deposition in the catchment amounted to $19,077 \mathrm{~m}^{3}$ of sediment for this run, indicating that significant amounts of sediment can be stored within valley-filled catchments. Only $3173 \mathrm{~m}^{3}$ of sediment was exported from the catchment in the reference run, showing that $1761 \mathrm{~m}^{3}$ of sediment was eroded from storage. As the drainage area of the catchment is 20.1 ha $\left(200,919 \mathrm{~m}^{3}\right)$, an erosion rate for the reference 
run based on sediment yield, sediment exported from catchment, was $15.8 \mathrm{~mm} \mathrm{kyr}^{-1}$. The modelled erosion rate for the finer and coarser grain size runs were 21.6 and $8.1 \mathrm{~mm} \mathrm{kyr}^{-1}$, respectively. Cumulative sediment yearly sediment yields for all catchments is shown in Figure 89. Centennial sediment yield displayed that catchment erosion was not constant through time (Fig. 90). Sediment yield from the first 100 years of the finer grain size run, $1151 \mathrm{~m}^{3}$, accounted for $\sim 27 \%$ of the total modeled sediment yield. Modeled sediment yields for the first 100 years of the reference and coarser runs were $\sim 20 \%$ and $\sim 10 \%$ of the total, respectively. The two finest grain sizes $(0.5$ and $1 \mathrm{~mm})$ comprised an average of $52.4 \%$ of total sediment yield.

Drainage density within the catchment increased in all model runs. Drainage density increased from 0.67 to $4.42 \mathrm{~km}^{-1}$ in the reference run (Fig. 91). Drainage density after 1000 years of model time in the finer and coarser runs increased to 4.13 and $4.25 \mathrm{~km}^{-1}$, respectively.

\section{Whitman \#8}

Modeling results from Whitman \#8 (Table 7), a groin-drain valley fill, showed that this fill was more resistant to erosion. The largest gully seen in the field on this catchment was infilled in all model runs. Both constructed drains were infilled for most of their length with aggradation commonly over $1 \mathrm{~m}$. In all model runs, the colluvial sideslope directly beside the north groin drain was undermined by diverted stream flow (Fig. 92). The constructed drain in this location filled in with coarse sediments, which caused the erosion into the fine sideslope sediments. The bedrock DEM created for this catchment limited the erosion where the stream undermined the slope to no more than $2 \mathrm{~m}$ depth. Very high values of erosion (9 m) were modeled to occur in what appears to be small pockets of LiDAR data artifacts, which led to initial slope values above the model's landslide threshold of $45^{\circ}$. The DoDs of the model runs were nearly identical. Just as in Whitman \#20, the sharp terrace edges rounded, and the bases of the slopes below the terraces became more concave as sediment accumulated at their base. Figure 93 shows the hillslope profile along three terrace-outslope pairs before and after 1000 years of landscape evolution in the reference run. 
A sediment volume of $14,468 \mathrm{~m}^{3}$ accumulated within Whitman $\# 8$ over the 1000 -year modeling period of the reference run. Cumulative yearly sediment yield showed that the reference, finer, and coarser grain size distribution model runs were much closer in the total volume of exported sediment relative to those modeled for the Whitman \#20 catchment (Fig. 94). Centennial sediment yields showed that the coarse grain size distribution model produced larger sediment yields much greater than the reference or fine runs during the same 100-year period, model years 500-600 (Fig. 95). The large yield in the coarser grain size run was due to the previously described undermining of the sideslope, which occurred in model year 528. The two finest grain sizes $(0.5$ and $1 \mathrm{~mm})$ comprised an average of $63.2 \%$ of total sediment yield amongst all runs. Erosion rates based on sediment yield for the reference, fine, and coarse runs were 4.3, 5.1, and $3.8 \mathrm{~mm} \mathrm{kyr}^{-1}$, respectively. Drainage density showed very small increases from the initial value of 2.67 $\mathrm{km}^{-1}$ in all model runs. The post-modeling drainage density values for the reference, fine, and coarse model runs were $2.79,2.80$, and $2.75 \mathrm{~km}^{-1}$, respectively.

\section{Whitman \#18}

Modeling results from Whitman \#18 (Table 7) showed heavy erosion on the toe of the valley fill and along a road paralleling the right-side groin drain (Fig. 96). Modeled erosion of the road was caused by avulsion into road from the right-side drain, which had locally aggraded. The modeled aggradation rerouted discharge into the road, which was separated from the drain by a $1 \mathrm{~m}$ ridge. The finer and coarser grain size distribution model runs showed erosion in the exact same area. The fine model run uniquely developed a gully on the first terrace-slope pair (Fig. 97). The modeled gully was caused by the overtopping of an adjacent sediment cell, which allowed flow over the edge of the terrace. In all model runs, a zone of deposition up to $4.6 \mathrm{~m}$ in depth formed on the toe directly above the outlet (Fig. 96). The road above the eroded area also experienced deposition of over $1 \mathrm{~m}$. As in the two previously described model catchments, sediment cells filled over the span of 1000 model years.

The catchment yielded $3254 \mathrm{~m}^{3}$ of sediment in the reference model run, which equated to an erosion rate of $8.5 \mathrm{~mm} \mathrm{kyr}^{-1}$. The finer and coarser grain size runs yielded erosion rates of 10.8 and $6.2 \mathrm{~mm} \mathrm{kyr}^{-1}$, 
respectively. Cumulative yearly sediment yields showed the same trends for all runs (Fig. 98). Centennial sediment yields showed that the largest yields can occur 800 years into model runs (Fig. 99). The two finest grain sizes $(0.5$ and $1 \mathrm{~mm})$ comprised an average of $45.6 \%$ of total sediment yield. Drainage density change comparison for this modeled catchment was not possible due to an irreparable malfunction (segmentation fault) in the algorithm while extracting the channel network for the initial topography. The reference, finer, and coarser model runs drainage densities were $3.33,3.38$, and $3.18 \mathrm{~km}^{-1}$, respectively, after the 1000-year modeling period.

\section{Scarlet \#1}

Scarlet \#1 modeling runs (Table 7) produced the most extensive erosion on the valley fill face of any modeled catchment (Fig. 100). In the reference run, a $\sim 15 \mathrm{~m}$ wide, $\sim 3 \mathrm{~m}$ deep gully formed on the last slope above the valley fill toe, and extended into the center drain for a total length of $\sim 64 \mathrm{~m}$. The same gully extended $\sim 200 \mathrm{~m}$ from the second terrace-slope pair to the toe in the finer grain size run. In all three model runs, this gully was initiated by erosion within the center drain at the toe, followed by headward extension into the valley fill face. All model runs produced a gully on the first terrace-slope pair due to a road routing flow towards the valley fill face. A large quantity of sediment was eroded from the right colluvial sideslope within a pre-existing gully. The catchment was given a bedrock topography DEM $2 \mathrm{~m}$ below the sideslope surface, which prevented deeper erosion into the sideslope. The modeling runs did not extend the pre-existing gully headward. The finer grain size model run produced gullies on all valley fill terrace-slope pairs (Fig. 101). Only the finer grain size run formed alluvial fans like those formed in all runs of Whitman \#20. The center drain of Scarlet \#1 does not flatten as it traverses a terrace, which made fan formation less likely within the model.

Modeled erosion rates for Scarlet \#1 were the highest among all catchments. Erosion rates for the reference, finer grain size, and coarser grain size runs were 19.2, 25.1, and $15.9 \mathrm{~mm} \mathrm{kyr}^{-1}$, respectively. Cumulative yearly sediment yields for all runs exhibited an extremely high first year yield due to erosion of the colluvial sideslope (Fig. 102) Figure 104 also shows elevated erosion in the finer grain size run 
after the 600-year mark, associated with headward retreat of the large gully on the valley fill face.

Centennial yields again showed that erosion can be high late in the modeling period, with the second highest yield for the finer grain size run occurring between years 701 and 800 (Fig. 103). These results suggest that downstream aggradation may be possible long after the construction of a valley fill. The two finest grain sizes averaged $60.7 \%$ of total sediment yield. Drainage density increased dramatically over the course of all modeling runs. Drainage density was $1.20 \mathrm{~km}^{-1}$ at the onset of modeling but increased to $3.67 \mathrm{~km}^{-1}$ in the reference run, $3.98 \mathrm{~km}^{-1}$ in the finer grain size run, and $4.06 \mathrm{~km}^{-1}$ in the coarser grain size run. In the finer grain size run, the increase in drainage density arose from development of the large gully and a detectable channel within the center drain.

\section{Boone-Kanawha-Raleigh \#1}

Boone-Kanawha-Raleigh \#1 (Table 7) was the only modeled valley-filled catchment to develop gullies in the backfill area above the valley fill (Fig. 104). The gullies (or single gully in finer grain size run) formed a shallow but wide fan on the top of the valley fill, which directed flow to the groin drains. The redirected flow eroded gullies just above the groin drains. As in Whitman \#20, modeled erosion occurred along the right-sided colluvial sideslope, just downslope of a contour mine road, due to undermining by diverted flow from the aggraded right-side groin drain. Contour mine roads that intersected each side of the valley fill face experienced mass wasting where the local slope angle exceeded the model failure threshold of $45^{\circ}$. The resultant mass-wasting deposits were not remobilized and did not affect modeled sediment yield. Groin drains were primarily zones of deposition in all runs on Boone-Kanawha-Raleigh \#1. As in all other modeled catchments, terrace edges rounded, and sediment cells infilled over the 1000year model runs.

Modelled erosion rates for the reference, finer grain size, and coarser grain size runs were 6.7, 8.6, and $4.2 \mathrm{~mm} \mathrm{kyr}^{-1}$, respectively. Sediment storage within the catchment, calculated from pixels with positive values in the DoD, totaled 28,662 $\mathrm{m}^{3}$. Cumulative yearly sediment yields from all runs showed similar trends (Fig. 105). Centennial yields again illustrated that the highest yields can occur deep into 1000-year 
modeling period (Fig. 106). The two finest grain sizes $(0.5$ and $1 \mathrm{~mm})$ comprised an average of $53.9 \%$ of total sediment yield. Drainage density increased from $4.24 \mathrm{~km}^{-1}$ to $6.53 \mathrm{~km}^{-1}$ during the reference run. Drainage density at the end of the finer grain size (Fig. 107) and coarse grain sizer runs were 6.10 and $6.71 \mathrm{~km}^{-1}$, respectively.

\section{Sensitivity Analysis}

The 500-year sensitivity analysis runs on Whitman \#8 showed that Manning's $n$ dominated all tested parameters in terms of modeled sediment yield. An increase from 0.06 to 0.08 in Manning's $n$ resulted in $1314 \mathrm{~m}^{3}$ or $\sim 360 \%$ more sediment being exported relative to the reference run, as shown in cumulative

yearly sediment yields (Fig. 108). The substantial increase is thought to be a product of the calculation of bed shear stress (Pa) within the CL LEM code, which uses Manning's $n$. (Coulthard, 2017). A DoD of the higher $n=0.08$ run showed much more erosion within both groin drains (Fig. 109). The erosion rate for the 0.08 Manning's $n$ run was $18.1 \mathrm{~mm} \mathrm{kyr}^{-1}, \sim 4.6$ times higher than the reference run. A decrease in $n$ to 0.04 yielded $2.5 \mathrm{~m}^{3}$ or $\sim 14506 \%$ less sediment than the reference run. A change in vegetational critical shear stress from $40 \mathrm{~Pa}$ to $30 \mathrm{~Pa}$ increased modeled sediment yield by $81 \mathrm{~m}^{3}$ or $\sim 22 \%$, and the change to $50 \mathrm{~Pa}$ increased yield by $87 \mathrm{~m}^{3}$ or $\sim 24 \%$. This counter-intuitive outcome is the result of a vegetationstripping model storm event, which lead to high yearly rates for several years post-event (Fig. 109) and the highest centennial yield (Fig. 110). The lower vegetational critical shear stress may have led to sediment exhaustion, low sediment availability, within the catchment (Hudson, 2003). The increase in the TOPMODEL $m$ parameter from 0.007 to 0.009 decreased sediment yield by $125 \mathrm{~m}^{3}$ or $52 \%$, and the decrease of $m$ to 0.005 increased yield by $70 \mathrm{~m}^{3}$ or $19 \%$. This trend is the expected result as lower $m$ values lead to flashier runoff, thus higher peak flows (Beven et al., 1995).

\section{Discussion}

\section{Gully Erosion}


As gully erosion has been observed on post-mining landscapes throughout the world (Haigh, 1980; Sawatsky and Tuttle, 1996; Sanz et. al, 2008), confirmation of the working hypothesis that gully erosion is an active process on fully reclaimed valley fills produced by MTR/VF is no surprise. Gully erosion on valley fills was observed in the field, LiDAR-derived DEMs, and landscape evolution modeling. The LiDAR observations showed the periphery of land directly affected by MTR/VF are more prone to gully erosion than the valley fills, a result which was not expected. Sediment cells are somewhat like drainage ditches on edges of roads on steep slopes. Previous research has shown that the unnatural concentration of flow in ditches associated with roads can induce gully erosion (Wemple et al., 2001; Nyssen et al., 2002). As gully erosion was so ubiquitous on MTR/VF land, multitemporal airborne LiDAR data may be the only way to track changes in gully erosion at a regional scale (Tarolli, 2014). Field data for a rigorous accuracy assessment (Congalton and Green, 2008) of features classified as gullies from LiDAR data could be difficult due to the vast majority of MTR/VF land being relatively inaccessible private property (Jaeger, 2015).

The trend of increasing gully head occurrence per unit area from NE to SW along the extent of MTR/VF region could be explained two ways: finer grain sediments or construction practices. Finer grain size modeling runs produced gullies more readily and with greater intensity. The OSM (2002) stability report on valley fills reported that much of friction angle values of mine spoil taken from Kentucky permit data were between $21-25^{\circ}$. The same study listed the West Virginia spoil friction angle values to fall mainly between $31-40^{\circ}$. These data suggest that the valley fills of Kentucky may have a finer grain size distribution, which would yield lower friction angles (Kolbuszewski and Frederick, 1963). Finer grained non-cohesive soils are more prone to erosion by concentrated water flow (Knapen et al., 2006). Direct petrological comparison of the rocks that compose valley fills across this proposed gradient, has not been undertaken. The alternative explanation of mining practices should also be explored as surface mining is regulated by each state individually (Michael and Superfesky, 2010) and construction practices have varied through time. 


\section{Landslides}

The landslides detected in MTR/VF affected land, including within valley fills, of the Floyd-Pike LiDAR dataset from Kentucky reinforce the hypothesis that the sediments composing valley fills and backfill areas are finer grain relative to the West Virginia MTR/VF land and would be weaker as mine spoils in terms of shear strength. The landslides detected within the valley fills of the Floyd-Pike and Perry-KnottBreathitt datasets were all considered fully reclaimed and require no maintenance in perpetuity. This is the first reported evidence of landslides within fully reclaimed valley fills; valley-fill landslides reported in the OSM (2002) stability report were on sites in the process of construction or reclamation. Onsite investigation of the landslides would be needed for a better understanding of the processes and materials involved (Crawford et al., 2015). Historical DEMs could be used to provide data on the steepness of the slopes upon which the failed valley fills were built, as the OSM stability report (2002) linked steep foundation slope to increased failure occurrence. The size of landslides in the Floyd-Pike dataset not occurring on the faces of the valley fills followed a power-law distribution, which comports with previous studies of landslide size distribution (Stark and Hovius, 2001). This lends a measure of credence to these results which cannot be validated by field work. Multitemporal LiDAR of the region affected by MTR/VF will be vital in the future to ascertain the risks associated with this newly discovered geohazard and to quantify erosion due to mass wasting (Jaboyedoff et al., 2012).

\section{Drainage density and depression storage capacity}

The low drainage density and high depression storage capacities generally exhibited by valley-filled catchments may help to explain depressed stormflow response, which has also been attributed to internal storage within the valley fill (Miller and Zegre, 2014; Nippgen et al., 2017). Some depressions within

valley-filled catchments are specifically designed to enhance infiltration into the valley fill (Wunsch et al., 1996), so the two observations may be linked. The CAESAR-Lisflood modeling showed that these initial conditions may change as time progresses, with drainage density increases and sediment cell infilling a common condition after 1000 modeled years of landscape evolution. Channel network extraction 
algorithms that do not initially fill the DEM may provide a better estimate of drainage density on valleyfilled catchments due to the enhanced depression storage capacity.

\section{Erosion rates from modeling}

The erosion rates from modeling averaged $10.9 \pm 6.9 \mathrm{~mm} \mathrm{kyr}^{-1}$, which is within the low range cosmogenically-derived catchment-averaged rates from the Appalachian Plateau of $7.5 \pm 0.7$ to $69.6 \pm 6.4$ mm kyr-1 (Miller et al., 2013). It must be considered that the modeled sediment yields, thus modeled erosion rates, are derived from bedload only, as no grain size was parameterized to travel as suspended load. Although, the smallest grain size used in modelling, $0.5 \mathrm{~mm}$, may travel in suspension during floods, silt is the dominant fraction of suspended load in the region (Outerbridge, 1987). Bedload-total load ratios from gravel-bedded rivers can be quite small, even during high flows (Turowski et al., 2010). This information combined with the lack of weathering described in Section 4.5 likely make the modeled erosion rates highly conservative. If the modeling run which used a Manning's $n$ of 0.08 more accurately simulates the erosion of valley fills, average erosion rates may be closer to $\sim 50 \mathrm{~mm} \mathrm{kyr}^{-1}$, which is closer to the mean catchment-averaged rates from Miller et al. (2013).

In a relative sense, the groin drain-style valley fills eroded slower than center drain-style valley fills with erosion rates of $6.5 \pm 2.4 \mathrm{~mm} \mathrm{kyr}^{-1}$ and $19.3 \pm \mathrm{mm} \mathrm{kyr}^{-1}$, respectively. This result suggests that a stream that drains a cluster of center drain-style valley-filled catchments might show more signs of aggradation than a nearby stream that drains a cluster of groin drain-style valley-filled catchments. The sensitivity analysis also predicts that hydrological response and vegetation can be as important as grain size distribution in controlling sediment yields from valley-filled catchments. Drainage area does not seem to play a major role in governing erosion rates, according to the model runs. Monitoring of bedload emanating from valley-filled catchments would need to be undertaken to discern if any of the modeled rates are close to reality. As many gullies and landslides are observed in the periphery of MTR/VF affected land not associated with valley fills, these areas might produce substantially more sediment than 
valley-filled catchments, and streams that incorporate both valley-filled catchments and long swaths of peripheral MTR/VF land should be monitored.

\section{Model Caveats}

The CAESAR-Lisflood landscape evolution model runs do not capture some processes which are relevant to valley-filled catchments. Chemical weathering in valley fills is very high due to acid dissolution of carbonates and the general availability of fresh minerals newly exhumed as overburden (Clark et al., 2016; Nippgen et al., 2017). Chemical weathering decreases rock shear strength values over time by increasing permeability (Hudec, 1998). CAESAR-Lisflood cannot yet capture chemical weathering. Physical weathering of valley fill sediments by freeze-thaw, bioturbation, wetting-drying, and thermal expansion-contraction is not captured as well. Field work provided evidence of physical weathering of boulders in constructed drains (Fig. 111). Physical weathering would act to comminute coarse sediment grains over time, leading to easier mobility (Sklar et al., 2017). CAESAR-Lisflood is capable of physical weathering simulation (Vanwalleghem et al., 2013), but was not parameterized in this project due to a lack of data. Possible deep-seated landslides in valley fills were observed in the LiDAR data of eastern Kentucky (Figs. 72, 74, and 75), which cannot be modeled in CAESAR-Lisflood. Landslides can dramatically change catchment-wide sediment availability, thus sediment yield (Kuo and Brierly, 2013). Gully headcut retreat and channel initiation can occur via seepage erosion from subsurface flow (Dunne, 1990), which is not possibly to model with CAESAR-Lisflood.

The modeling runs tacitly assume that repair or mitigation of valley fills will not occur in the future due to the existing reclamation law. It is impossible to predict if this will be the case. Also, the vegetation parameters remain constant throughout the modeling period. Although the return of valley fills to forest has been negligible due to management practices and inherently poor soils, new reclamation goals and construction techniques that reduce surface compaction may address this problem (Zipper et al., 2011). Other model parameters such as Manning's $n$ and the TOPMODEL $m$ parameter are assumed to be static throughout the 1000-year modeling period. A validation of the model results (Rykiel, 1995) is not 
currently possible without sediment yield data, but the model reproduced erosional features comparable to those seen in the field and LiDAR. Observations of increased fine sediment downstream of valley fills by Wiley et al. (2001) and Jaeger (2015) also supports model results, as sediment yields of 0.5 and $1 \mathrm{~mm}$ grains averaged $55 \%$ of total sediment across all runs.

\section{Conclusions}

- Inset fluvial channels are developing within the constructed drains and can erode valley fill sediments.

- Both surface and subsurface flow can induce erosion on valley fill faces.

- Gully erosion is regionally widespread on lands affected by MTR/VF, especially on the periphery.

- Gullies are observable in the field, LiDAR, and landscape evolution modeling output.

- A trend of increasing gully erosion occurrence exists along a NE-SW transect across West Virginia and Kentucky that spans the region most affected by MTR/VF.

- Landslides are present in the peripheral backfill areas above natural slopes in West Virginia MTR/VF land but appear to be more widespread in eastern Kentucky.

- Landslides are occurring within the fully reclaimed valley fills of eastern Kentucky.

- Drainage density is significantly lower in valley-filled catchments relative to less disturbed catchments.

- Macro-scale depression storage capacity is significantly higher in valley-filled catchments.

- Landscape evolution modeling suggests that average erosion rates within valley-filled catchments based solely on bedload sediment yields are $10.9 \mathrm{~mm} \mathrm{kyr}^{-1}$, and that erosion rates within centerdrain style valley-filled catchments are higher than those with groin drains. 


\section{References:}

Amoah, J. K., Amatya, D. M., and Nnaji, S. (2013). Quantifying watershed surface depression storage: determination and application in a hydrologic model. Hydrological Processes, 27(17), 2401-2413.

Bates, P. D., Horritt, M. S., and Fewtrell, T. J. (2010). A simple inertial formulation of the shallow water equations for efficient two-dimensional flood inundation modelling. Journal of Hydrology, 387(1-2), 3345.

Bell, J. C., Daniels, W. L., and Zipper, C. E. (1989). The practice of "approximate original contour" in the Central Appalachians. I. Slope stability and erosion potential. Landscape and urban planning, 18(2), 127138.

Benda, L., Hassan, M. A., Church, M., and May, C. L. (2005). Geomorphology of steepland headwaters: the transition from hillslopes to channels. Journal of the American Water Resources Association, 41(4), 835

Bernhardt, E. S., and Palmer, M. A. (2011). The environmental costs of mountaintop mining valley fill operations for aquatic ecosystems of the Central Appalachians. Annals of the New York Academy of Sciences, 1223(1), 39-57.

Beven, K. J., and Kirkby, M. J. (1979). A physically based, variable contributing area model of basin hydrology. Hydrological Sciences Journal, 24(1), 43-69.

Beven, K., Lamb R., Quinn, P., Romaniwicz, R., and Freer, J. (1995). TOPMODEL. in Singh, V. P. (ed), Computer Models of Watershed Hydrology. Water Resources Pub., 627-668.

Brocca, L., Liersch, S., Melone, F., Moramarco, T., and Volk, M. (2013). Application of a model-based rainfall-runoff database as efficient tool for flood risk management. Hydrology and Earth System Sciences, 17(8), 3159.

Castillo, C., Taguas, E. V., Zarco-Tejada, P., James, M. R., and Gómez, J. A. (2014). The normalized topographic method: an automated procedure for gully mapping using GIS. Earth Surface Processes and Landforms, 39(15), 2002-2015.

Cenderelli, D. A., and Kite, J. S. (1998). Geomorphic effects of large debris flows on channel morphology at North Fork Mountain, eastern West Virginia, USA. Earth Surface Processes and Landforms, 23(1), 119.

Chestnut, D. R. (1993). Eustatic and tectonic control of sedimentation in the Pennsylvanian strata of the Central Appalachian Basin, USA. in Compte Rendu, Douzieme Congres International de la Stratigraphie et Geologie du Carbonifere et Permien, Buenos Aires, 1991, Volume 2: pp. 421-460.

Chow, V. (1959). Open-Channel Hydraulics: New York, McGraw-Hill, 700 p.

Clark, E. V., Greer, B. M., Zipper, C. E., and Hester, E. T. (2016). Specific conductance-stage relationships in Appalachian valley fill streams. Environmental Earth Sciences, 75(17), 1222.

Clubb, F. J., Mudd, S. M., Attal, M., Milodowski, D. T., and Grieve, S. W. (2016). The relationship between drainage density, erosion rate, and hilltop curvature: Implications for sediment transport processes. Journal of Geophysical Research: Earth Surface, 121(10), 1724-1745. 
Collier, C. R. (1964). Hydrologic influences of strip mining: Influences of strip mining on the hydrologic environment of parts of Beaver Creek basin, Kentucky, 1955-59 (No. 427-B).

Congalton, R. G., and Green, K. (2008). Assessing the accuracy of remotely sensed data: principles and practices. CRC Press, $200 \mathrm{p}$.

Coulthard, T. J. (2017). CAESAR-Lisflood 1.9b source. Zenodo. http://doi.org/10.5281/zenodo.321820

Coulthard, T. J., and Van De Wiel, M. J. (2017). Modelling long term basin scale sediment connectivity, driven by spatial land use changes. Geomorphology, 277, 265-281.

Coulthard, T. J., Macklin, M. G., and Kirkby, M. J. (2002). A cellular model of Holocene upland river basin and alluvial fan evolution. Earth Surface Processes and Landforms, 27(3), 269-288.

Coulthard, T. J., Neal, J. C., Bates, P. D., Ramirez, J., Almeida, G. A., and Hancock, G. R. (2013). Integrating the LISFLOOD-FP 2D hydrodynamic model with the CAESAR model: implications for modelling landscape evolution. Earth Surface Processes and Landforms, 38(15), 1897-1906.

Coulthard, T. J., Ramirez, J., Fowler, H. J., and Glenis, V. (2012). Using the UKCP09 probabilistic scenarios to model the amplified impact of climate change on drainage basin sediment yield. Hydrology and Earth System Sciences, 16(11), 4401.

Cowpertwait, P. S. P., O'Connell, P. E., Metcalfe, A. V., and Mawdsley, J. A. (1996). Stochastic point process modelling of rainfall. I. Single-site fitting and validation. Journal of Hydrology, 175(1-4), 17-46.

Crawford, M. M., Zhu, J., and Webb, S. E. (2015). Geologic, geotechnical, and geophysical investigation of a shallow landslide, eastern Kentucky. Environmental \& Engineering Geoscience, 21(3), 181-195.

Cunningham, C. V. B. (1987). Fragmentation estimations and the Kuz-Ram model: Four years on. In Proceedings 2nd International Symposium on Rock Fragmentation by Blasting, p. 475-487.

Curtis, W. R., and Superfesky, M. J. (1977). Erosion of surface mine spoils. Proceedings Soil Conservation Society of America. 154-158.

Daniels, W. L., and Zipper, C. E. (2010). Creation and management of productive minesoils. Power River Project Reclamation Guidelines for Surface-mined Land. Publication 460-121.

DePriest, N. C., Hopkinson, L. C., Quaranta, J. D., Michael, P. R., and Ziemkiewicz, P. F. (2015). Geomorphic landform design alternatives for an existing valley fill in central Appalachia, USA: Quantifying the key issues. Ecological Engineering, 81, 19-29.

Dyer, K. L., and Curtis, W. R. (1977). Effect of strip mining on water quality in small streams in eastern Kentucky, 1967-1975. USDA Forest Service Research Paper NE (USA). no. 372.

Eaton, L. S., Morgan, B. A., Kochel, R. C., and Howard, A. D. (2003). Quaternary deposits and landscape evolution of the central Blue Ridge of Virginia. Geomorphology, 56(1), 139-154.

Eeckhaut, M., Poesen, J., Verstraeten, G., Vanacker, V., Nyssen, J., Moeyersons, J., and Vandekerckhove, L. (2007). Use of LIDAR-derived images for mapping old landslides under forest. Earth Surface Processes and Landforms, 32(5), 754-769.

Ehlke, T. A., Runner, G. S., and Downs, S. C. (1982). Hydrology of Area 9, Eastern Coal Province, West Virginia (No. 81-803). US Geological Survey. 
Englund, K. J., Arndt, H. H., Schweinfurth, S. P., and Gillespie, W. H. (1986). Pennsylvanian system stratotype sections, West Virginia. Southeastern Section of the Geological Society of America, 59-68.

Evaldi, R. D. (2001). Flood of July 2001 in West Virginia. in US Geological Survey Appalachian Region Integrated Science Workshop Proceedings, Gatlinburg, Tennessee, October 2001, p. 58-65.

Evans, M., and Lindsay, J. (2010). High resolution quantification of gully erosion in upland peatlands at the landscape scale. Earth Surface Processes and Landforms, 35(8), 876-886.

Fedorko, N., and Blake, M. (1998). A geologic overview of mountaintop removal mining in West Virginia. Executive Summary of a Report to the Committee on Post-Mining Land Use and Economic Aspects of Mountaintop Removal Mining. West Virginia Geologic and Economic Survey (WVGES).

Fenneman, N. M. (1938). Physiography of the eastern United States. McGraw-Hill Book Co., New York.

Fischer, E. M., Beyerle, U., and Knutti, R. (2013). Robust spatially aggregated projections of climate extremes. Nature Climate Change, 3(12), 1033-1038.

Fox, J. F. (2009). Identification of sediment sources in forested watersheds with surface coal mining disturbance using carbon and nitrogen isotopes. Journal of the American Water Resources Association, 45(5), 1273-1289.

Google Earth. (2015). UTM 17N 449633.00 m E 4195071.00 m N.

Google Earth. (2016). UTM 17N 500762.00 m E 4241919.00 m N.

Greb, S. F., Pashin, J. C., Martino, R. L., and Eble, C. F. (2008). Appalachian sedimentary cycles during the Pennsylvanian: Changing influences of sea level, climate, and tectonics. Geological Society of America Special Papers, 441, 235-248.

Greer, B. M., Burbey, T. J., Zipper, C. E., and Hester, E. T. (2017). Electrical resistivity imaging of hydrologic flow through surface coal mine valley fills with comparison to other landforms. Hydrological Processes, 31(12), 2244-2260.

Grieve, S. W., Mudd, S. M., Hurst, M. D., and Milodowski, D. T. (2016a). A nondimensional framework for exploring the relief structure of landscapes. Earth Surface Dynamics, 4(2), 309.

Griffith, M. B., Norton, S. B., Alexander, L. C., Pollard, A. I., and LeDuc, S. D. (2012). The effects of mountaintop mines and valley fills on the physicochemical quality of stream ecosystems in the central Appalachians: a review. Science of the Total Environment, 417, 1-12.

Guebert, M. D., and Gardner, T. W. (2001). Macropore flow on a reclaimed surface mine: infiltration and hillslope hydrology. Geomorphology, 39(3), 151-169.

Hack, J. T., and Goodlett, J. C. (1960). Geomorphology and forest ecology of a mountain region in the central Appalachians (No. 347). United States Government Printing Office.

Haering, K. C., Daniels, W. L., and Galbraith, J. M. (2004). Appalachian mine soil morphology and properties. Soil Science Society of America Journal, 68(4), 1315-1325.

Haigh, M. J. (1980). Slope retreat and gullying on revegetated surface mine dumps, Waun Hoscyn, Gwent. Earth Surface Processes and Landforms, 5(1), 77-79. 
Haigh, M. J. (1992). Problems in the reclamation of coal-mine disturbed lands in Wales. International Journal of Surface Mining, Reclamation and Environment, 6(1), 31-37.

Hancock, G. R. (2004). The use of landscape evolution models in mining rehabilitation design. Environmental Geology, 46(5), 561-573.

Hancock, G. R., Loch, R. J., and Willgoose, G. R. (2003). The design of post-mining landscapes using geomorphic principles. Earth Surface Processes and Landforms, 28(10), 1097-1110.

Hancock, G. R., Lowry, J. B. C., and Coulthard, T. J. (2015). Catchment reconstruction-erosional stability at millennial time scales using landscape evolution models. Geomorphology, 231, 15-27.

Hancock, G. R., Verdon-Kidd, D., and Lowry, J. B. C. (2017). Sediment output from a post-mining catchment-Centennial impacts using stochastically generated rainfall. Journal of Hydrology, 544, 180194.

Hancock, G., and Kirwan, M. (2007). Summit erosion rates deduced from 10Be: Implications for relief production in the central Appalachians. Geology, 35(1), 89-92.

Hawkins, J. W., and Aljoe, W. W. (1992). Pseudokarst groundwater hydrologic characteristics of a mine spoil aquifer. Mine Water and the Environment, 11(2), 37-52.

Hooke, R. L. (1999). Spatial distribution of human geomorphic activity in the United States: comparison with rivers. Earth Surface Processes and Landforms, 24(8), 687-692.

Hooke, R. L. (2000). On the history of humans as geomorphic agents. Geology, 28(9), 843-846.

Howard, A. D. (1999). Simulation of Gully Erosion and Bistable Landforms. Incised river channels: processes, forms, engineering, and management, 277.

Huddle, J. W., and Englund, K. J. (1966). Geology and coal reserves of the Kermit and Varney area, Kentucky (No. 507). United States Government Printing Office.

Hudec, P. P. (1998). Rock properties and physical processes of rapid weathering and deterioration. In Proceedings of 8th International Congress of IAEG (Vol. 1, pp. 335-341). Balkema Rotterdam.

Jaboyedoff, M., Oppikofer, T., Abellán, A., Derron, M. H., Loye, A., Metzger, R., and Pedrazzini, A. (2012). Use of LIDAR in landslide investigations: a review. Natural hazards, 61(1), 5-28.

Jackson, B. C. (2015). Total Cost Optimization for Contour Blasting in the Appalachia Region. Master's Thesis. College of Engineering. University of Kentucky.

Jaeger, K. L. (2015). Reach-scale geomorphic differences between headwater streams draining mountaintop mined and unmined catchments. Geomorphology, 236, 25-33.

James, L. A., Watson, D. G., and Hansen, W. F. (2007). Using LiDAR data to map gullies and headwater streams under forest canopy: South Carolina, USA. Catena, 71(1), 132-144.

Kirkby, M. J., and Statham, I. (1975). Surface stone movement and scree formation. The Journal of Geology, 349-362.

Kite, J. S. (2009). A Geomorphologist Perspective on Stream and Watershed Restoration in the Appalachian Coal Fields. in Proceedings of geomorphic reclamation and natural stream design at coal mines: a technical interactive forum, Bristol, Virginia, April 2009, p. 3-12. 
Kite, J. S., Smith, J., and Rengers, F.K. (2003). Deranged drainage in Appalachian headwaters impacted by surface mining and reclamation. Geological Society of America Abstracts with Programs, 35(6), 213.

Knapen, A., Poesen, J., Govers, G., Gyssels, G., and Nachtergaele, J. (2007). Resistance of soils to concentrated flow erosion: A review. Earth-Science Reviews, 80(1-2), 75-109.

Kolbuszewski, J., and Frederick, M. R. (1963). The significance of particle shape and size on the mechanical behavior of granular materials. in Proceedings of European conference on the soil mechanics and foundation engineering, p. 253-263.

Kondolf, G. M. (1997). Application of the pebble count notes on purpose, method, and variants. Journal of the American Water Resources Association, 33(1), 79-87.

Konsoer, K. M., and Kite, J. S. (2014). Application of LiDAR and discriminant analysis to determine landscape characteristics for different types of slope failures in heavily vegetated, steep terrain: Horseshoe Run watershed, West Virginia. Geomorphology, 224, 192-202.

Kottek, M., Grieser, J., Beck, C., Rudolf, B., and Rubel, F. (2006). World map of the Köppen-Geiger climate classification updated. Meteorologische Zeitschrift, 15(3), 259-263.

Krumbein, W. C. (1932). The mechanical analysis of fine-grained sediments. Journal of Sedimentary Research, 2(3).

Lashermes, B., Foufoula-Georgiou, E., and Dietrich, W. E. (2007). Channel network extraction from high resolution topography using wavelets. Geophysical Research Letters, 34(23),

Major, J. J. (1997). Depositional processes in large-scale debris-flow experiments. The Journal of Geology, 105(3), 345-366.

Martín-Duque, J. F., Sanz, M. A., Bodoque, J. M., Lucía, A., and Martín-Moreno, C. (2010). Restoring earth surface processes through landform design. A 13-year monitoring of a geomorphic reclamation model for quarries on slopes. Earth Surface Processes and Landforms, 35(5), 531-548.

Martino, R. L. (1996). Stratigraphy and depositional environments of the Kanawha Formation (Middle Pennsylvanian), southern West Virginia, USA. International Journal of Coal Geology, 31(1), 217-248.

Maxa, M., and Bolstad, P. (2009). Mapping northern wetlands with high resolution satellite images and LiDAR. Wetlands, 29(1), 248-260.

Maxwell, A. E., and Strager, M. P. (2013). Assessing landform alterations induced by mountaintop mining. Natural Science, 5(2), 229-237.

McFee, W. W., Byrnes, W. R., and Stockton, J. G. (1981). Characteristics of Coal Mine Overburden Important to Plant Growth. Journal of Environmental Quality, 10(3), 300-308.

Michael, P. R., and Superfesky, M. J. (2007). Assuring Stability of Minimized Valley Fills: A Review of Potential Causes of Instability and Available Countermeasures. in Proceedings of 2007 National Meeting of the American Society of Mining and Reclamation. Gillette, Wyoming, p. 457-491.

Miller, A. J., and Zégre, N. P. (2014). Mountaintop removal mining and catchment hydrology. Water, 6(3), 472-499. 
Miller, S. R., Sak, P. B., Kirby, E., and Bierman, P. R. (2013). Neogene rejuvenation of central Appalachian topography: Evidence for differential rock uplift from stream profiles and erosion rates. Earth and Planetary Science Letters, 369, 1-12.

Montgomery, D. R. (1994). Road surface drainage, channel initiation, and slope instability. Water Resources Research, 30(6), 1925-1932.

Nippgen, F., Ross, M. R., Bernhardt, E. S., and McGlynn, B. L. (2017). Creating a More Perennial Problem? Mountaintop Removal Coal Mining Enhances and Sustains Saline Baseflows of Appalachian Watersheds. Environmental science \& technology, 51(15), 8324-8334.

O'Callaghan, J. F., \& Mark, D. M. (1984). The extraction of drainage networks from digital elevation data. Computer vision, graphics, and image processing, 28(3), 323-344.

Osterkamp, W. R., Joseph, W. L., Barnhisel, R. I., Darmody, R. G., and Daniels, W. L. (2000). 8. Climatic and hydrologic factors associated with reclamation. Reclamation of Drastically Disturbed Lands, 193-215.

Ouchterlony, F., Sanchidrián, J. A., and Moser, P. (2017). Percentile Fragment Size Predictions for Blasted Rock and the Fragmentation-Energy Fan. Rock Mechanics and Rock Engineering, 50(4), 751779 .

Outerbridge, W. F. (1987). The Logan plateau, a young physiographic region in West Virginia, Kentucky, Virginia, and Tennessee (No. 1620). USGPO.

Passalacqua, P., Belmont, P., and Foufoula-Georgiou, E. (2012). Automatic geomorphic feature extraction from lidar in flat and engineered landscapes. Water Resources Research, 48(3).

Pate, R. N. (2008) Soil Survey of Mingo and Logan counties, West Virginia. National Resource Conservation Service.

Pelletier, J. D. (2013). A robust, two-parameter method for the extraction of drainage networks from highresolution digital elevation models (DEMs): Evaluation using synthetic and real-world DEMs. Water Resources Research, 49(1), 75-89.

Pond, G. J., Passmore, M. E., Borsuk, F. A., Reynolds, L., and Rose, C. J. (2008). Downstream effects of mountaintop coal mining: comparing biological conditions using family-and genus-level

macroinvertebrate bioassessment tools. Journal of the North American Benthological Society, 27(3), 717737

PRISM Climate Group. (2015). Thirty year normal of precipitation and temperature for the United States. http://prism.oregonstate.edu/normals/.

Reed, M. M., and Kite, J. S. (2017). Observations of erosion on valley fills produced by mountaintop removal coal mining: Geological Society of America Abstracts with Programs. Vol. 49, No. 6 doi: 10.1130/abs/2017AM-301267

Risk Assessment and Security Partners. (2013). West Virginia Tug Watershed QA/QC Report. https://tagis.dep.wv.gov/data/lidar/Metadata/WVDEP_deliverable_2_RAMPP_quality_assessment.pdf

Roering, J. J., Mackey, B. H., Marshall, J. A., Sweeney, K. E., Deligne, N. I., Booth, A. M., and Cerovski-Darriau, C. (2013). 'You are HERE': Connecting the dots with airborne lidar for geomorphic fieldwork. Geomorphology, 200, 172-183. 
Ross, M. R., McGlynn, B. L., and Bernhardt, E. S. (2016). Deep impact: effects of mountaintop mining on surface topography, bedrock structure, and downstream waters. Environmental science \& technology, 50(4), 2064-2074.

Rykiel, E. J. (1996). Testing ecological models: the meaning of validation. Ecological modelling, 90(3), 229-244.

Saltelli, A., and Annoni, P. (2010). How to avoid a perfunctory sensitivity analysis. Environmental Modelling \& Software, 25(12), 1508-1517.

Sanz, M. A., Martín-Duque, J. F., Martín-Moreno, C., Lucía, A., Nicolau, J. M., Pedraza, J., and García, A. (2008). Silica sand slope gullying and mining in Central Spain: erosion processes and geomorphic reclamation of contour mining (pp. 3-14). WIT Press: Southampton.

Sawatsky, L., and Tuttle, S. (1996). Occurrence and growth of gullies on mine disturbed land. In Conservation and Reclamation: An Ecosystem Perspective.

Schor, H. J., and Gray, D. H. (2007). Landforming: an environmental approach to hillside development, mine reclamation and watershed restoration. John Wiley \& Sons.

Skinner, C. and Coulthard, T. (2017). CAESAR-Lisflood existing applications parameter listings. Zenodo. https://doi.org/10.5281/zenodo.800557.

Skinner, C., Coulthard, T., Schwanghart, W., Van DeWiel, M., and Hancock, G. (2017). Global Sensitivity Analysis of Parameter Uncertainty in Landscape Evolution Models. Geoscientific Model Development. https://doi.org/10.5194/gmd-2017-236.

Sklar, L. S., Riebe, C. S., Marshall, J. A., Genetti, J., Leclere, S., Lukens, C. L., and Merces, V. (2017). The problem of predicting the size distribution of sediment supplied by hillslopes to rivers. Geomorphology, 277, 31-49.

SkyTruth. (2009). SkyTruth Mountaintop Removal Mining, Part 1: Measuring the Extent of Mountaintop Removal in Appalachia. https://www.skytruth.org/2009/12/measuring-mountaintop-removal-mining-in/.

Smith, J. A., Baeck, M. L., Ntelekos, A. A., Villarini, G., \& Steiner, M. (2011). Extreme rainfall and flooding from orographic thunderstorms in the central Appalachians. Water Resources Research, 47(4).

Soil Survey Staff. (2016). Web Soil Survey. Natural Resources Conservation Service, United States Department of Agriculture. https://websoilsurvey.sc.egov.usda.gov/.

Springer, G. S., Kite, J. S., and Schmidt, V. A. (1997). Cave sedimentation, genesis, and erosional history in the Cheat River Canyon, West Virginia. Geological Society of America Bulletin, 109(5), 524-532.

Stark, C. P., and Hovius, N. (2001). The characterization of landslide size distributions. Geophysical Research Letters, 28(6), 1091-1094.

Strausbaugh, P. D., and Core, E. L. (1978). Flora of West Virginia, SenecaBooks. Inc., Grantsville, West Virginia.

Syvitski, J. P., Vörösmarty, C. J., Kettner, A. J., and Green, P. (2005). Impact of humans on the flux of terrestrial sediment to the global coastal ocean. Science, 308(5720), 376-380. 
Takasu, T., and Yasuda, A. (2009). Development of the low-cost RTK-GPS receiver with an open source program package RTKLIB. In International symposium on GPS/GNSS (pp. 4-6). International Convention Center Jeju Korea.

Tarboton, D. G. (1997). A new method for the determination of flow directions and upslope areas in grid digital elevation models. Water resources research, 33(2), 309-319.

Tarolli, P. (2014). High-resolution topography for understanding Earth surface processes: Opportunities and challenges. Geomorphology, 216, 295-312.

Tarolli, P., and Sofia, G. (2016). Human topographic signatures and derived geomorphic processes across landscapes. Geomorphology, 255, 140-161.

Taylor, S. B., and Kite, J. S. (2006). Comparative geomorphic analysis of surficial deposits at three central Appalachian watersheds: Implications for controls on sediment-transport efficiency.

Geomorphology, 78(1), 22-43.

Townsend, P. A., Helmers, D. P., Kingdon, C. C., McNeil, B. E., de Beurs, K. M., and Eshleman, K. N. (2009). Changes in the extent of surface mining and reclamation in the Central Appalachians detected using a 1976-2006 Landsat time series. Remote Sensing of Environment, 113(1), 62-72.

Tucker, G. E., and Hancock, G. R. (2010). Modelling landscape evolution. Earth Surface Processes and Landforms, 35(1), 28-50.

Turowski, J. M., Rickenmann, D., and Dadson, S. J. (2010). The partitioning of the total sediment load of a river into suspended load and bedload: a review of empirical data. Sedimentology, 57(4), 1126-1146.

U.S. Office of Surface Mining. (2002b). Long-Term Stability of Valley Fills. Appendices A-C to: U.S. Environmental Protection Agency. 2005. Final Programmatic Environmental Impact StatementMountaintop Mining/Valley Fills in Appalachia. EPA 9-03-R-00013. EPA Region 3, Philadelphia, PA. 49 pp. plus appendices

Ullah, W., and Dickinson, W. T. (1979). Quantitative description of depression storage using a digital surface model: I. Determination of depression storage. Journal of Hydrology, 42(1-2), 63-75.

US Environmental Protection Agency (EPA). (2011). The Effects of Mountaintop Mines and Valley Fills on Aquatic Ecosystems of the Central Appalachian Coalfields; US EPA: Washington, DC, USA; p. 153.

Van De Wiel, M. J., Coulthard, T. J., Macklin, M. G., and Lewin, J. (2007). Embedding reach-scale fluvial dynamics within the CAESAR cellular automaton landscape evolution model. Geomorphology, 90(3-4), 283-301.

Vanwalleghem, T., Stockmann, U., Minasny, B., and McBratney, A. B. (2013). A quantitative model for integrating landscape evolution and soil formation. Journal of Geophysical Research: Earth Surface, 118(2), 331-347.

Welsh, S., Loughman, Z. J., Thoma, R. F., and Fetzner, J. W. (2016). Conservation of imperiled crayfish species-Cambarus veteranus (Decapoda: Cambaridae). Journal of Crustacean Biology, 35(6), 850-860.

West Virginia Economic and Geological Survey (WVGES) Coal Bed Mapping Project. (2013). http://ims.wvgs.wvnet.edu/coalims.htm 
Wiener, N. (1949). Extrapolation, interpolation, and smoothing of stationary time series: with engineering applications. Cambridge, MA., MIT Press, 176 p.

Wilcock, P. R., and Crowe, J. C. (2003). Surface-based transport model for mixed-size sediment. Journal of Hydraulic Engineering, 129(2), 120-128.

Wiley, J. B., Evaldi, R. D., Eychaner, J. H., and Chambers, D. B. (2001). Reconnaissance of stream geomorphology, low streamflow, and stream temperature in the mountaintop coal-mining region, southern West Virginia, 1999-2000. Water Resources Investigations Report. United States Geological Survey, (4092), 42.

Wilson, C. A. M. E., Stoesser, T., Bates, P. D., and Pinzen, A. B. (2003). Open channel flow through different forms of submerged flexible vegetation. Journal of Hydraulic Engineering, 129(11), 847-853.

Wunsch, D. R., Dinger, J. S., Taylor, P. B., Carey, D. I., and Graham, C. D. R. (1996). Hydrogeology, hydrogeochemistry, and spoil settlement at a large mine-spoil area in eastern Kentucky: Star Fire Tract. Report of Investigations, 10.

Ziliani, L., Surian, N., Coulthard, T. J., and Tarantola, S. (2013). Reduced-complexity modeling of braided rivers: Assessing model performance by sensitivity analysis, calibration, and validation. Journal of Geophysical Research: Earth Surface, 118(4), 2243-2262.

Zipper, C. E., Burger, J. A., Skousen, J. G., Angel, P. N., Barton, C. D., Davis, V., and Franklin, J. A. (2011). Restoring forests and associated ecosystem services on Appalachian coal surface mines. Environmental Management, 47(5), 751-765.

Zipper, C. E., Daniels, W. L., and Bell, J. C. (1989). The practice of "approximate original contour" in the central Appalachians. II. Economic and environmental consequences of an alternative. Landscape and Urban Planning, 18(2), 139-152. 


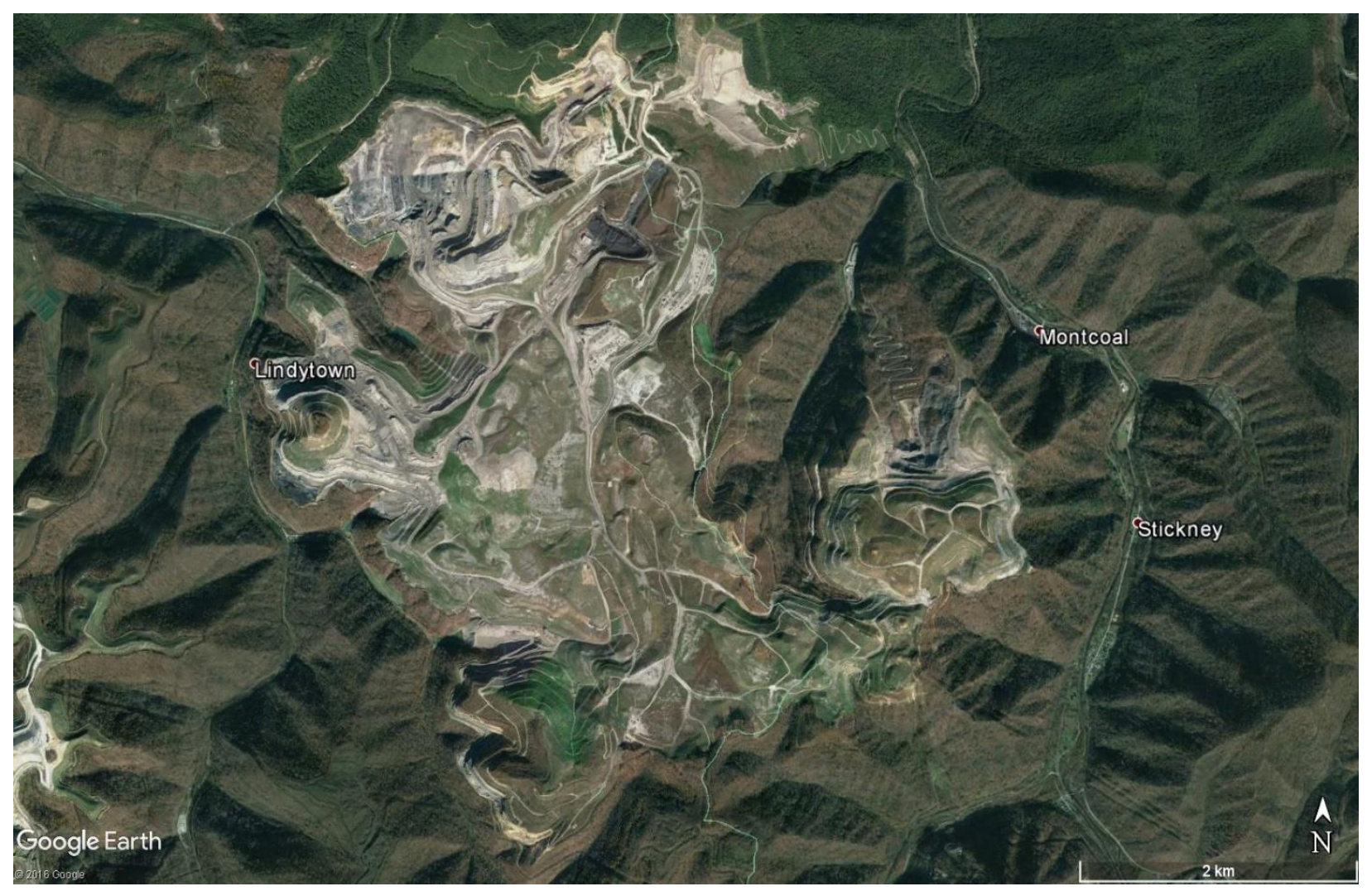

Figure 1. Google Earth image of mountaintop removal/valley fill (MTR/VF) mine in Boone and Raleigh counties, West Viriginia, showing the drastic topographic alteration associated with MTR/VF (Google Earth, 2015). View is from directly above at an altitude of $8.72 \mathrm{~km}$. 


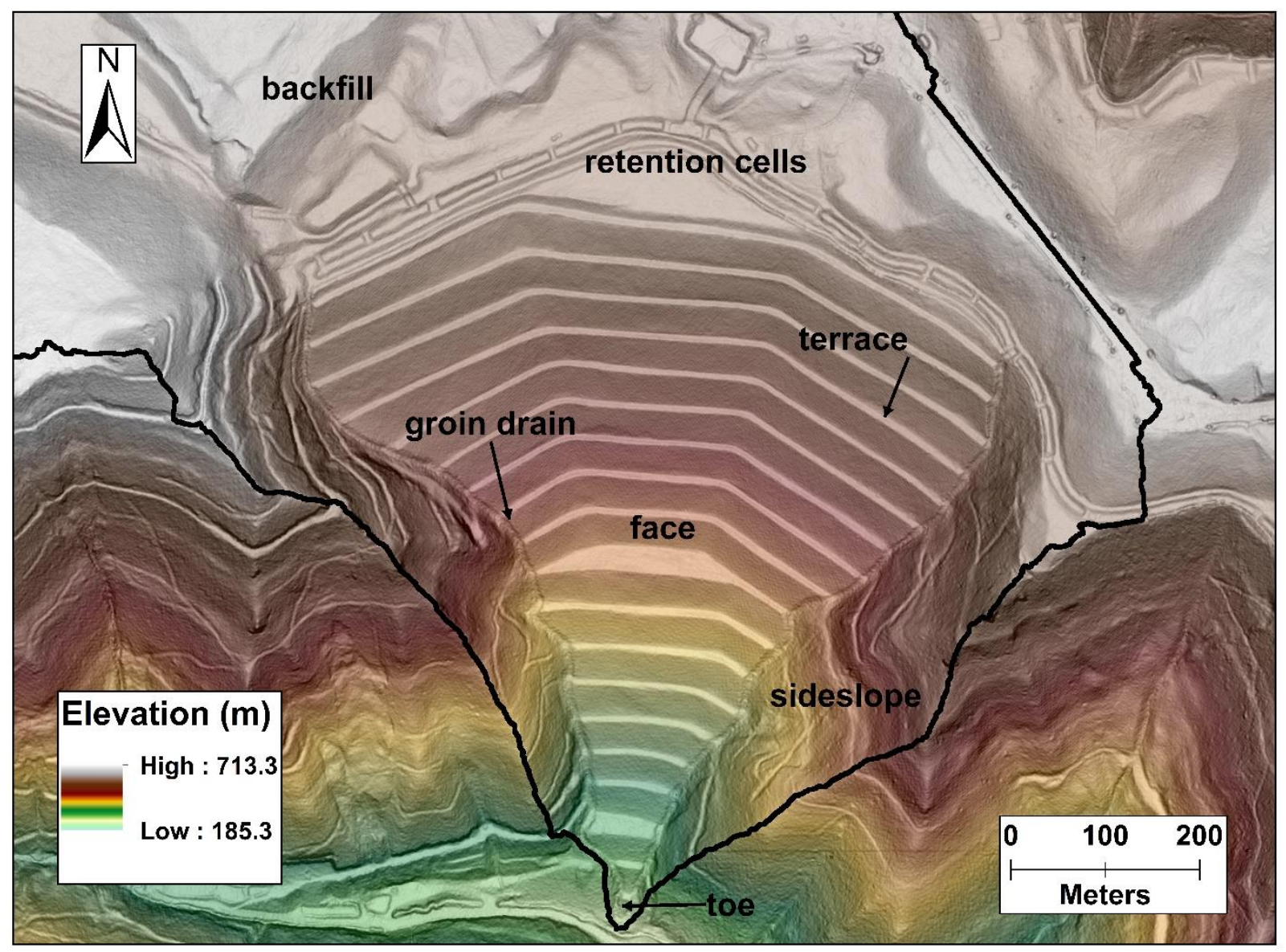

Figure 2. A $1 \mathrm{~m}$ LiDAR-derived, colorized digital elevation model with transparent slopeshade of a valley fill landform located near Amherstdale, Logan County, West Virginia [NAVD 88, NAD 83, UTM Zone $17 \mathrm{~N}]$. Landform elements labeled in black. The black line is the drainage divide. 


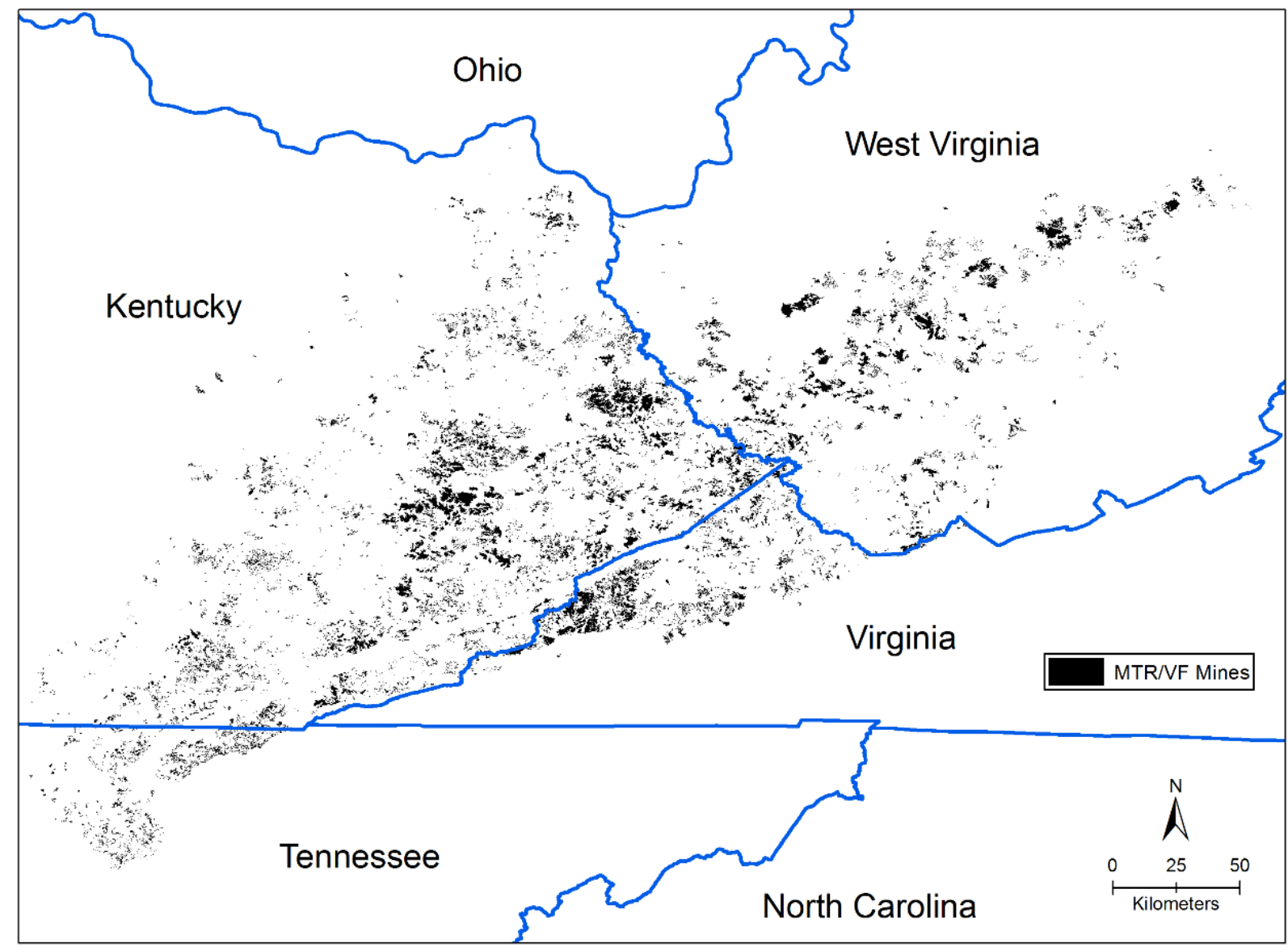

Figure 3. Map of the extent of mountaintop removal/valley fill mining. There were over 6000 valley fills in Central Appalachia when the EPA counted in 2002 (EPA). Remotely sensed MTR/VF mine extents from SkyTruth (2009). 


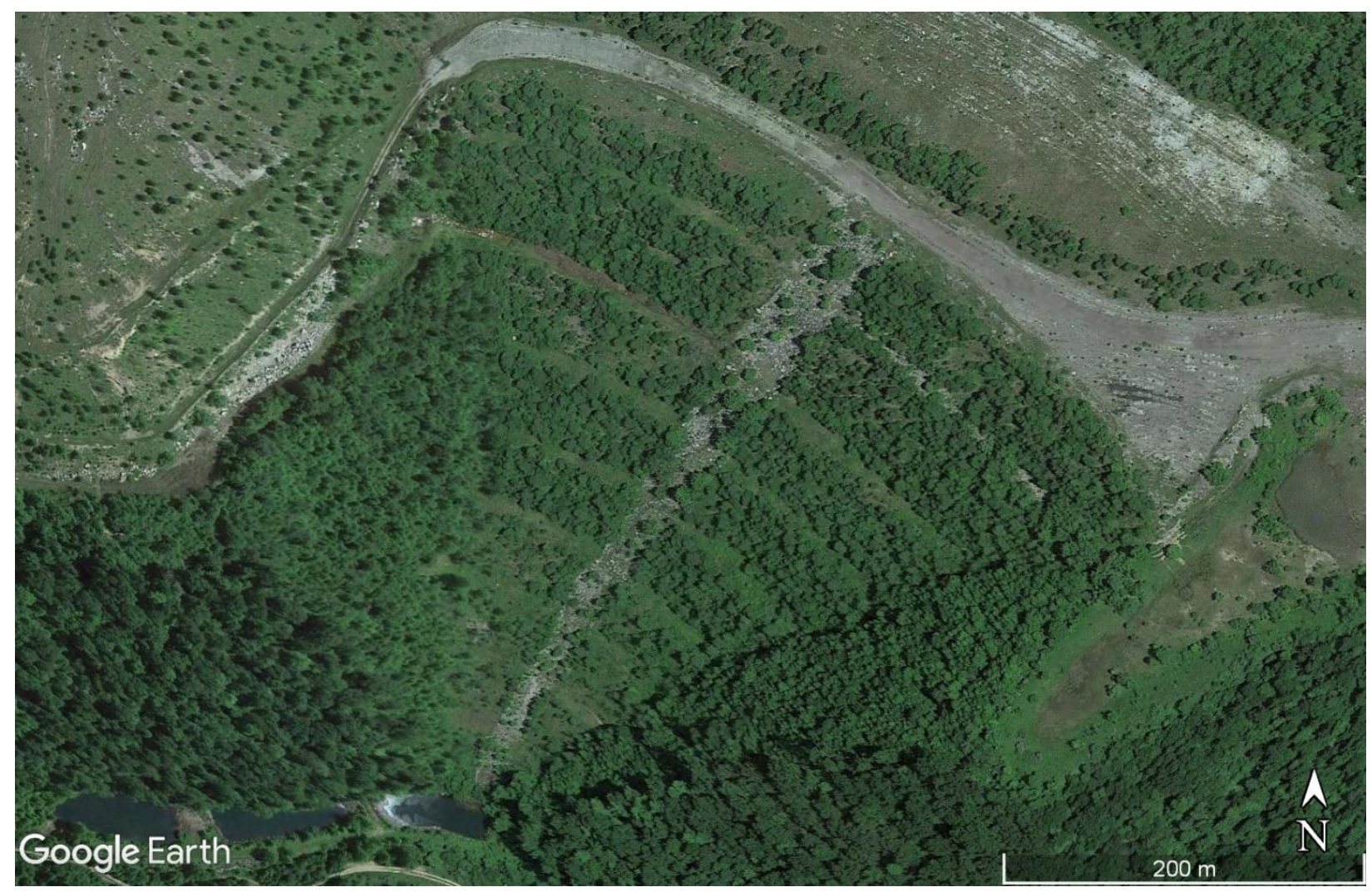

Figure 4. Reclaimed center-drain valley fill in Nicolas County, West Virginia (Google Earth, 2016). View is from directly above from an eye altitude of $1.08 \mathrm{~km}$. Relief from the haulage road on top of the fill to the sediment pond at the base is $130 \mathrm{~m}$. 


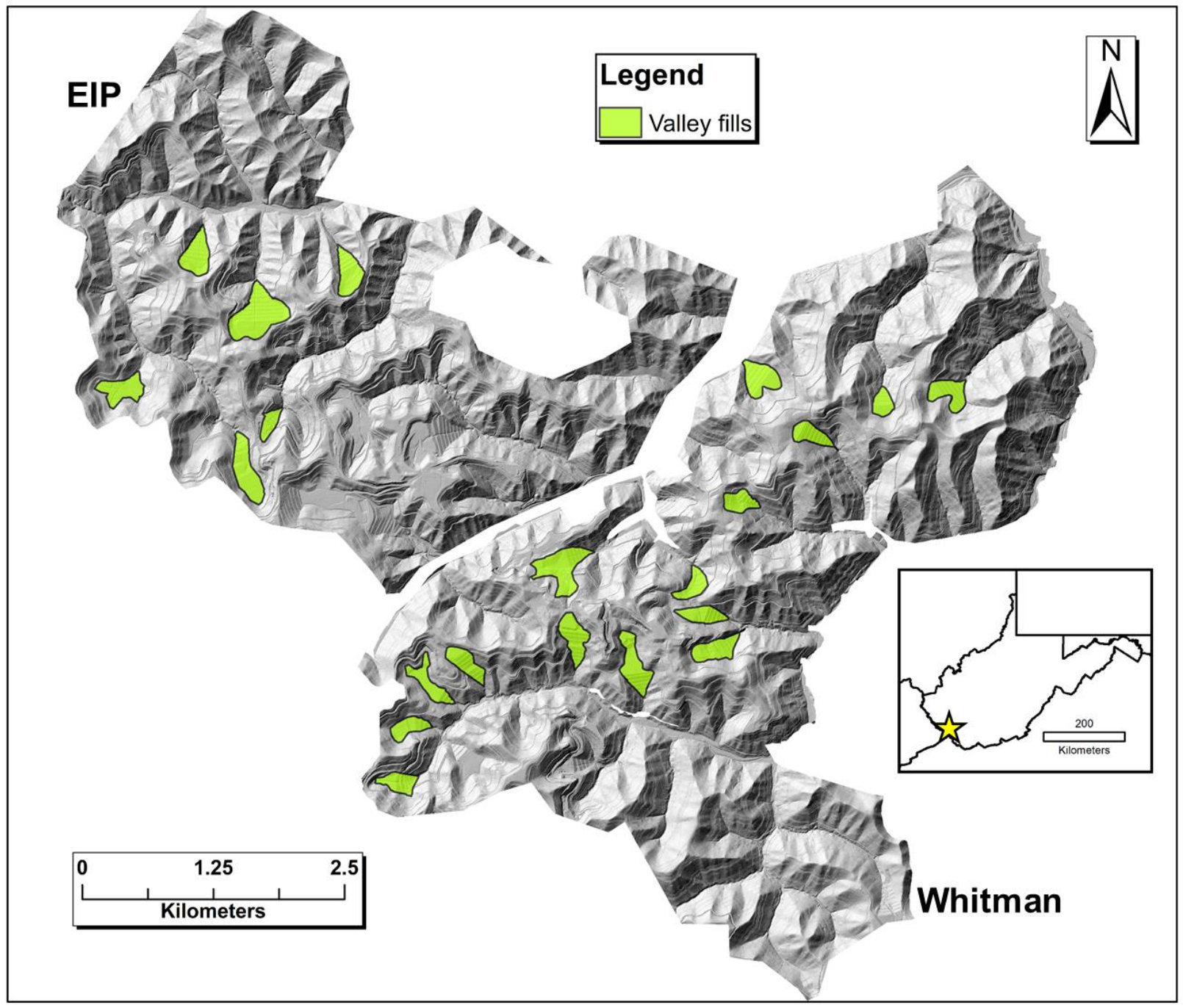

Figure 5. A $1 \mathrm{~m}$ LiDAR-derived hillshade of field study areas (EIP Copperas and Whitman West) with valley fills that were assessed for erosion in green. Inset: Location of field study areas near Logan, West Virginia. 


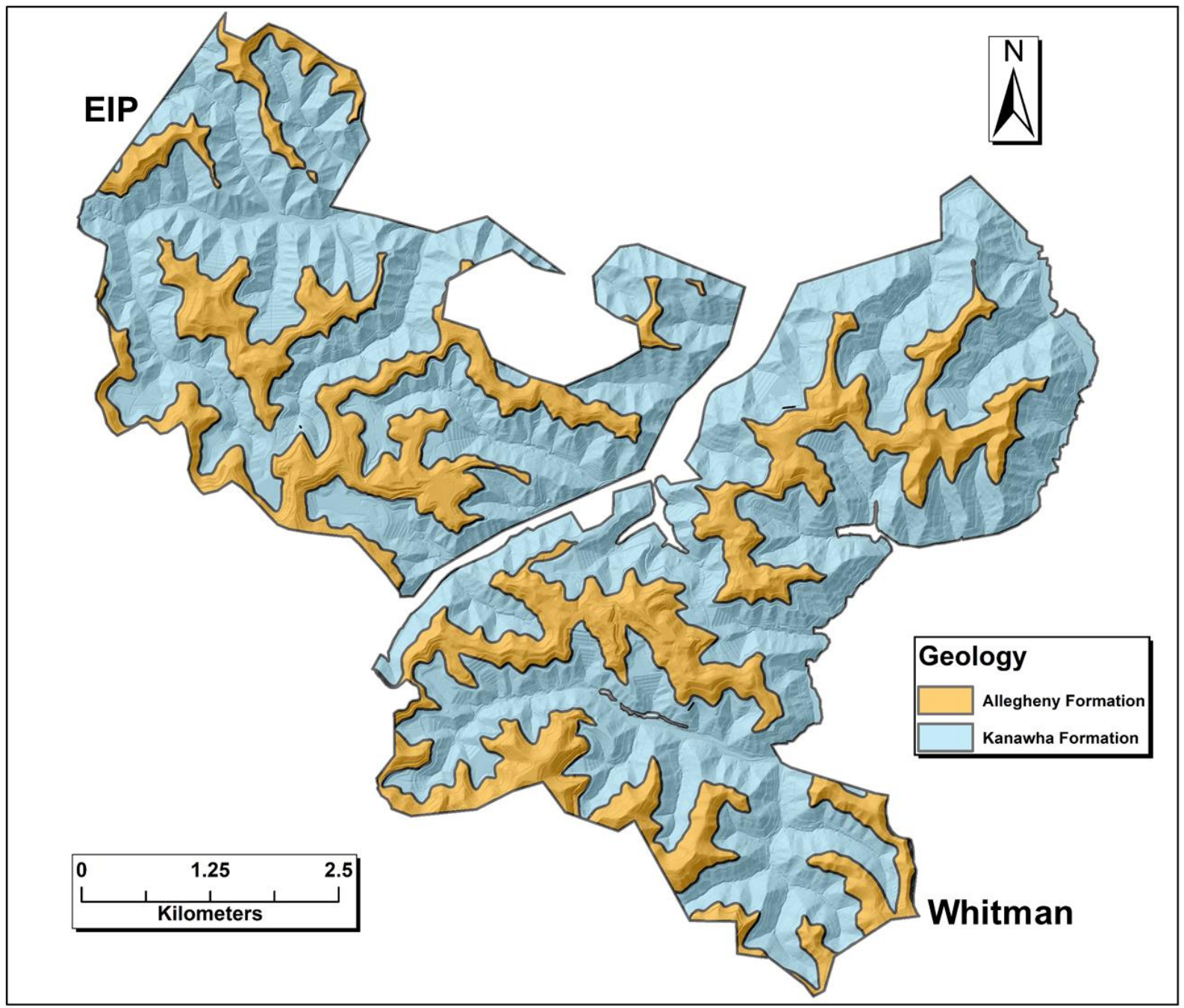

Figure 6. Geology of field study areas based on West Virginia Economic and Geologic Survey Coal Bed Mapping Layers (WVGES, 2013). The boundary used between the Kanawha Formation and Allegheny Formation is the Stockton A coal. The geology between field study areas and valley fills therein was assumed to be very similar. 


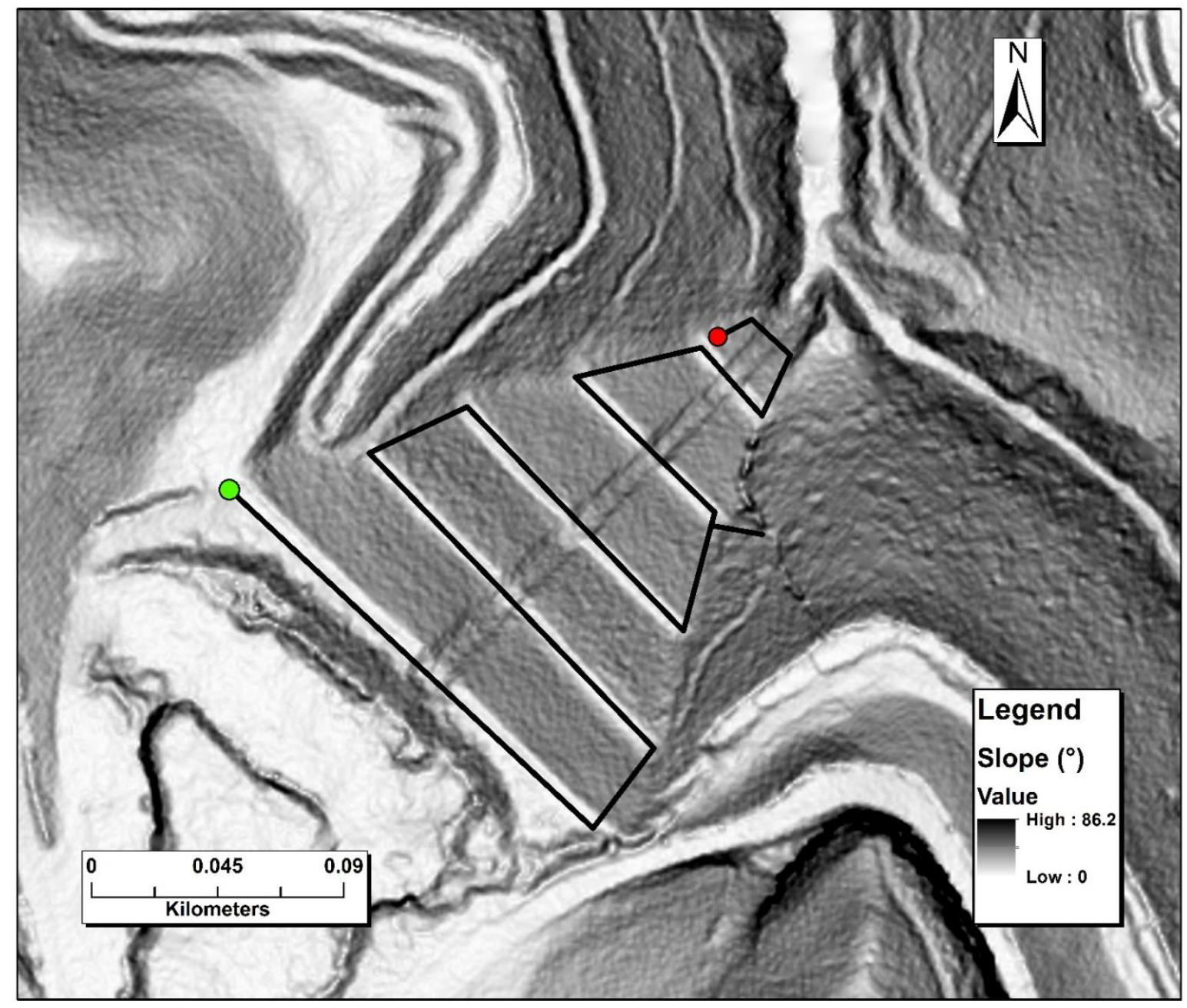

Figure 7. A $1 \mathrm{~m}$ LiDAR-derived slopeshade of EIP showing the typical route taken when assessing a valley fill for erosional features. The green dot is the starting point, and the red dot is the endpoint. The small line going eastward to the sideslope represents the observation of an erosional feature on the sideslope that is interacting with the valley fill face. 


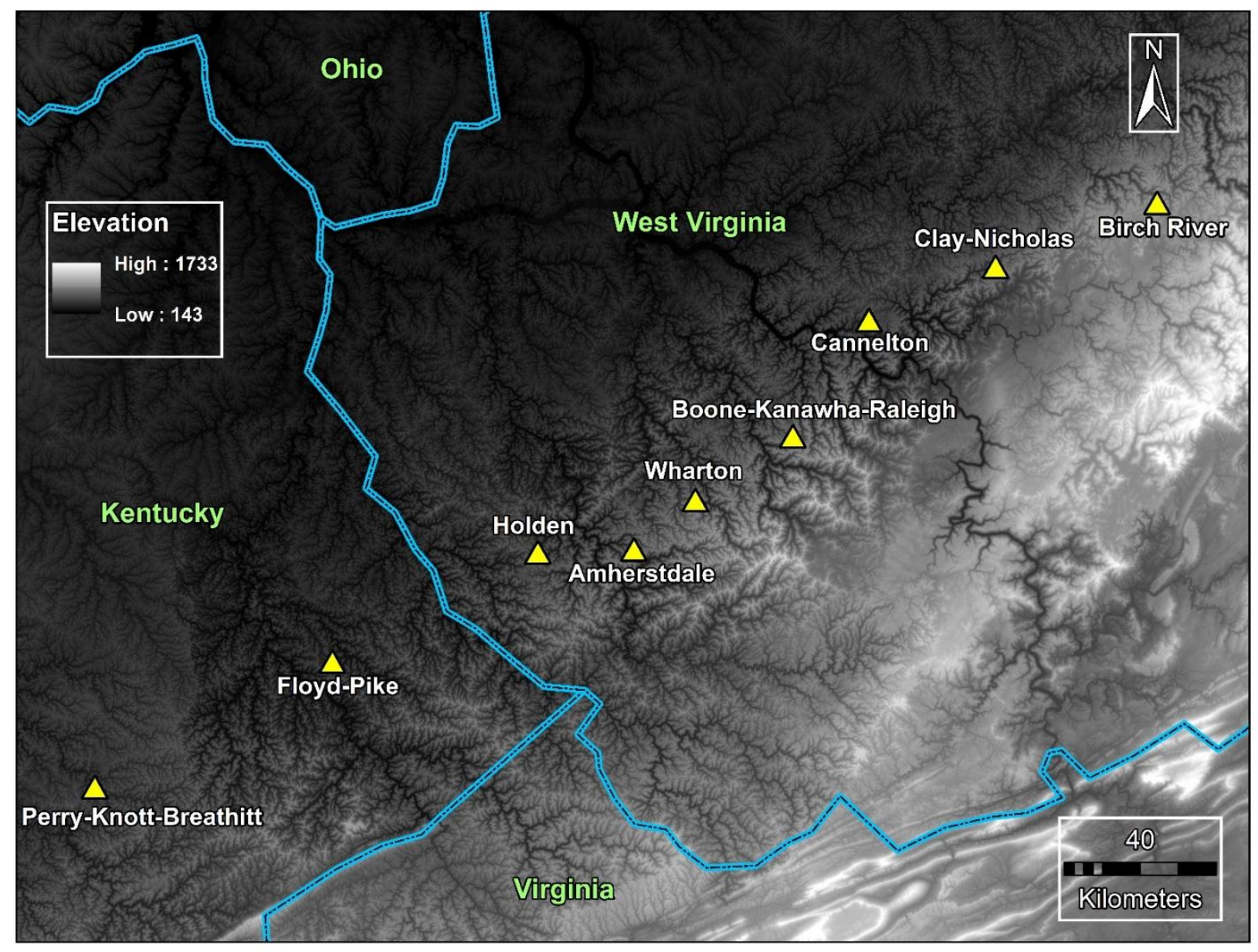

Figure 8. Locations of all LiDAR datasets (yellow triangles) used in this study overlaid onto the Shuttle Radar Topography Mission 1 arc-second DEM. The Holden dataset contains the field study areas. The datasets were used to make observations of erosional features and to measure catchment morphometrics like drainage density. 


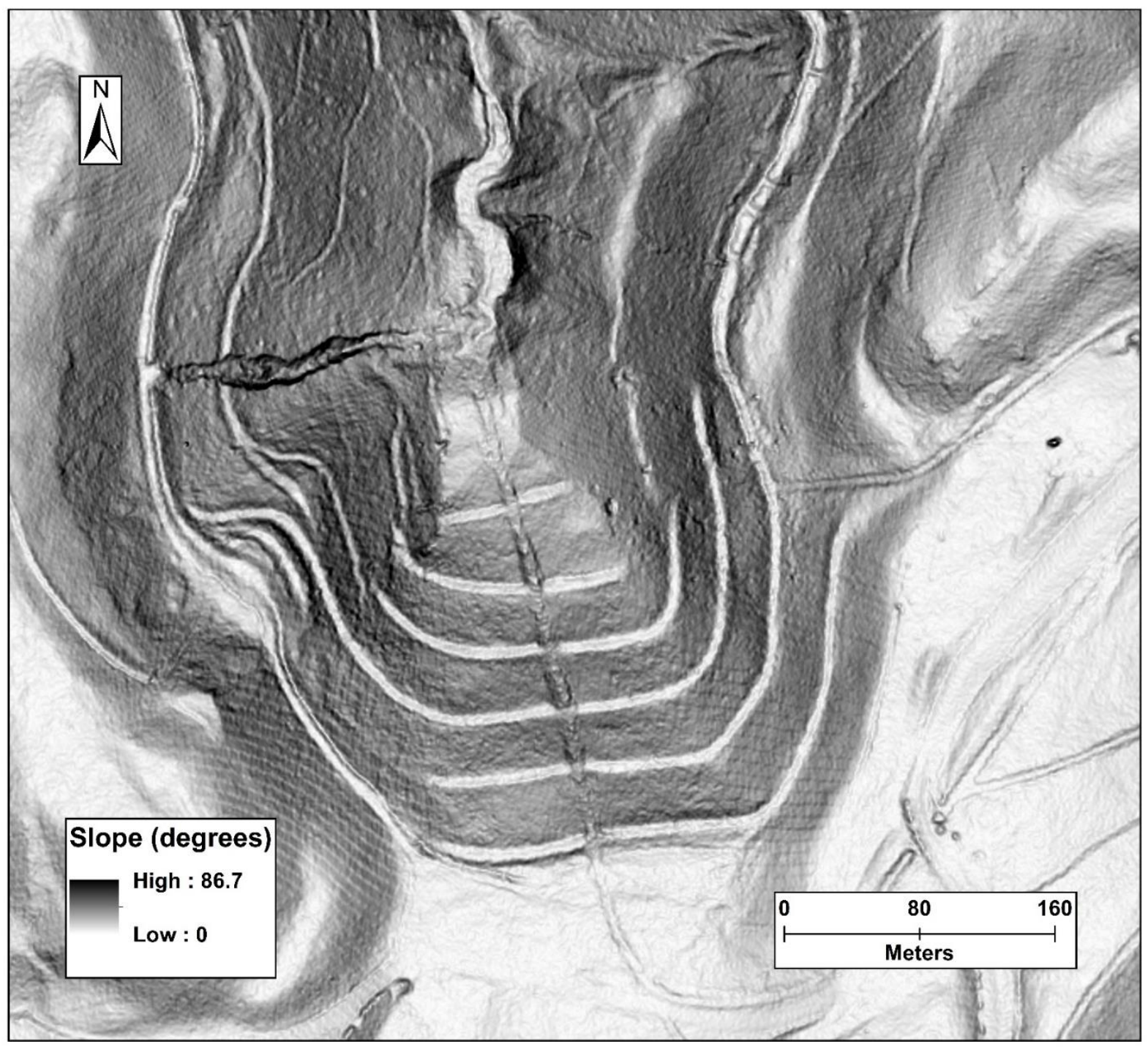

Figure 9. A $1 \mathrm{~m}$ LiDAR-derived slopeshade of a large gully emanating from sediment cell outlet located (left side of image). The image is from the Clay-Nicholas dataset. The gully is $\sim 6 \mathrm{~m}$ deep and $\sim 15 \mathrm{~m}$ wide (as measured using the LiDAR). 


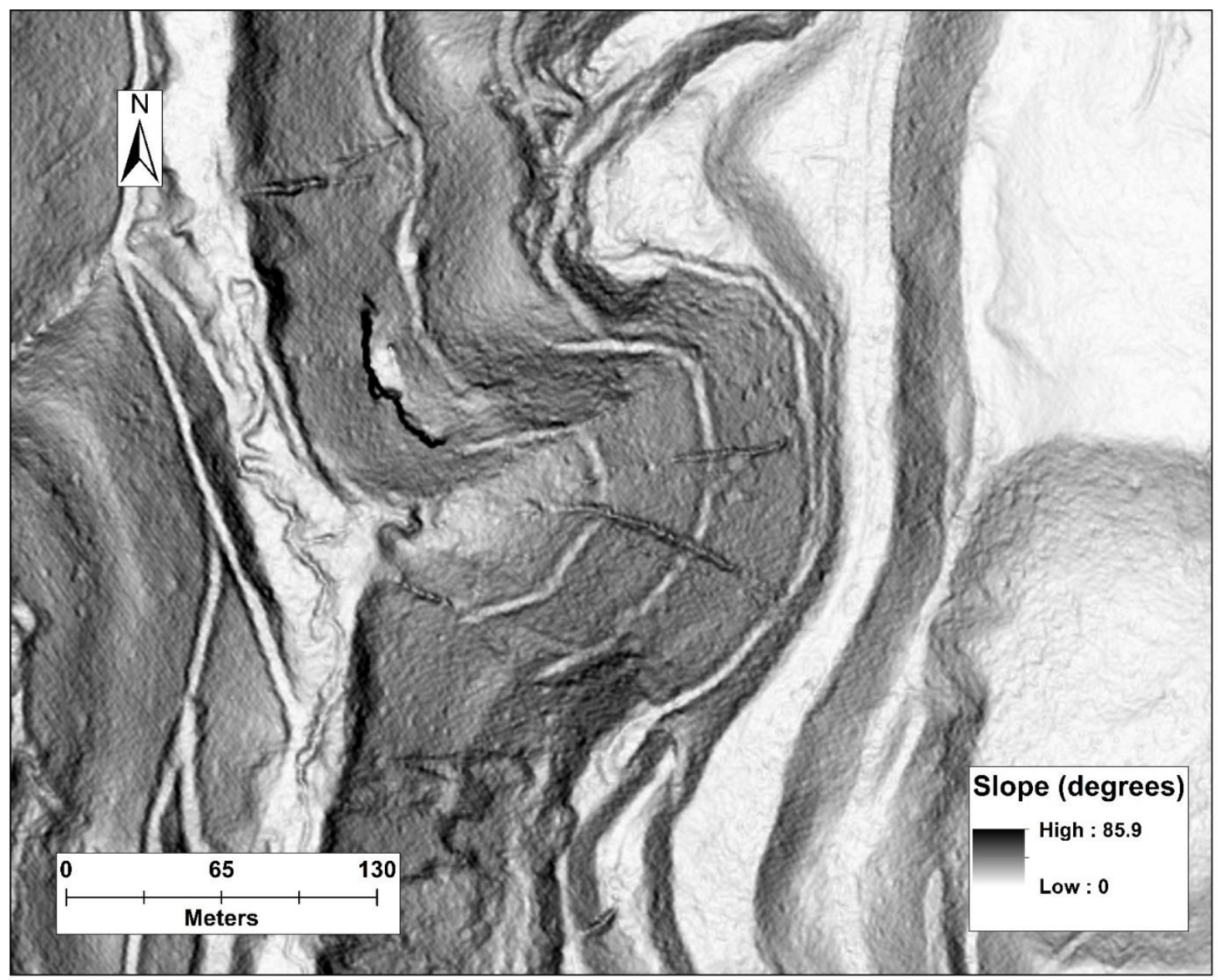

Figure 10. A $1 \mathrm{~m}$ LiDAR-derived slopeshade of several gullies occurring on the face of a valley fill. The valley fill is from the Perry-Knott-Breathitt dataset. 


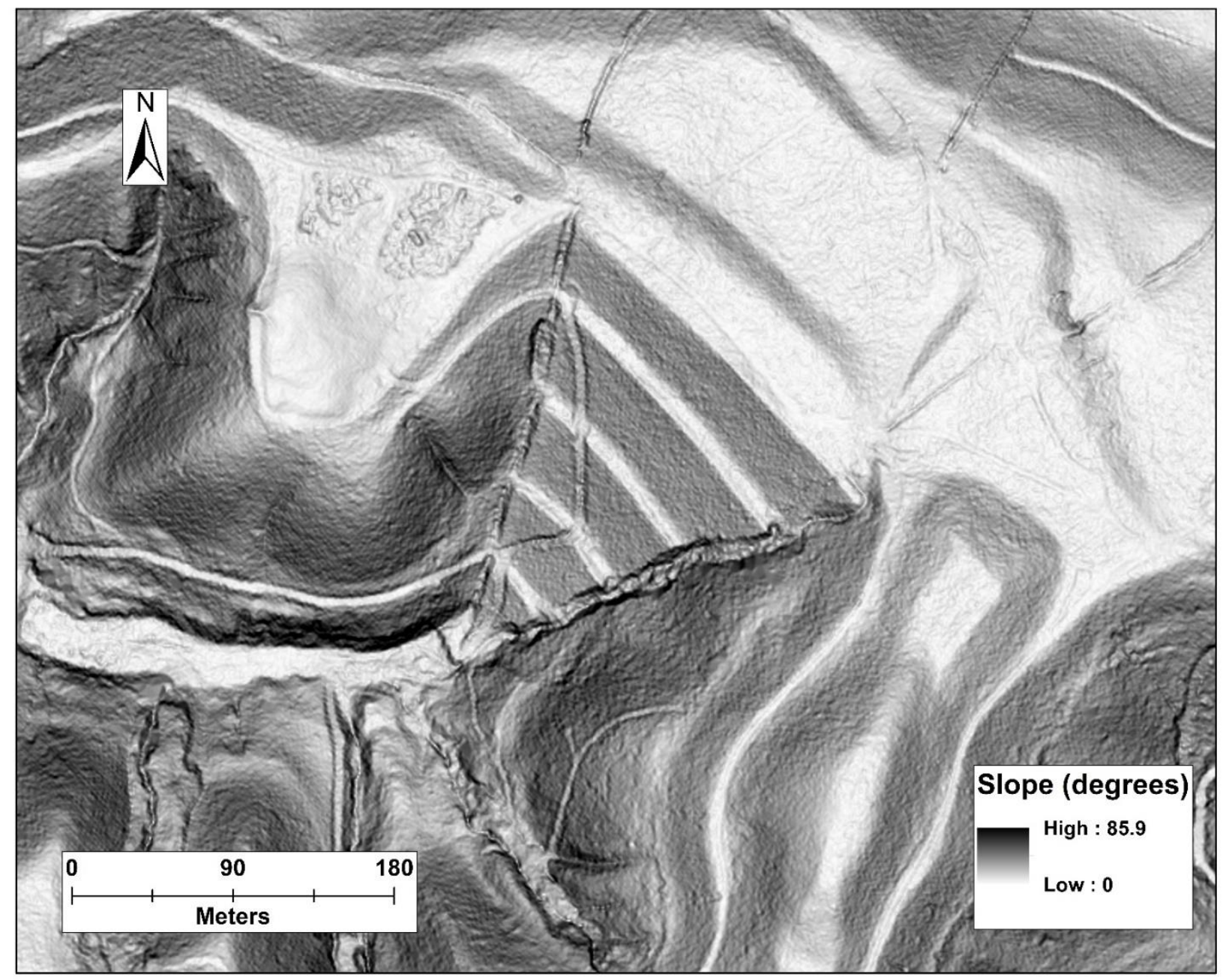

Figure 11. A $1 \mathrm{~m}$ LiDAR-derived slopeshade of an enlarged drain on a valley fill. The valley fill is located within the Perry-Knott-Breathitt dataset. 


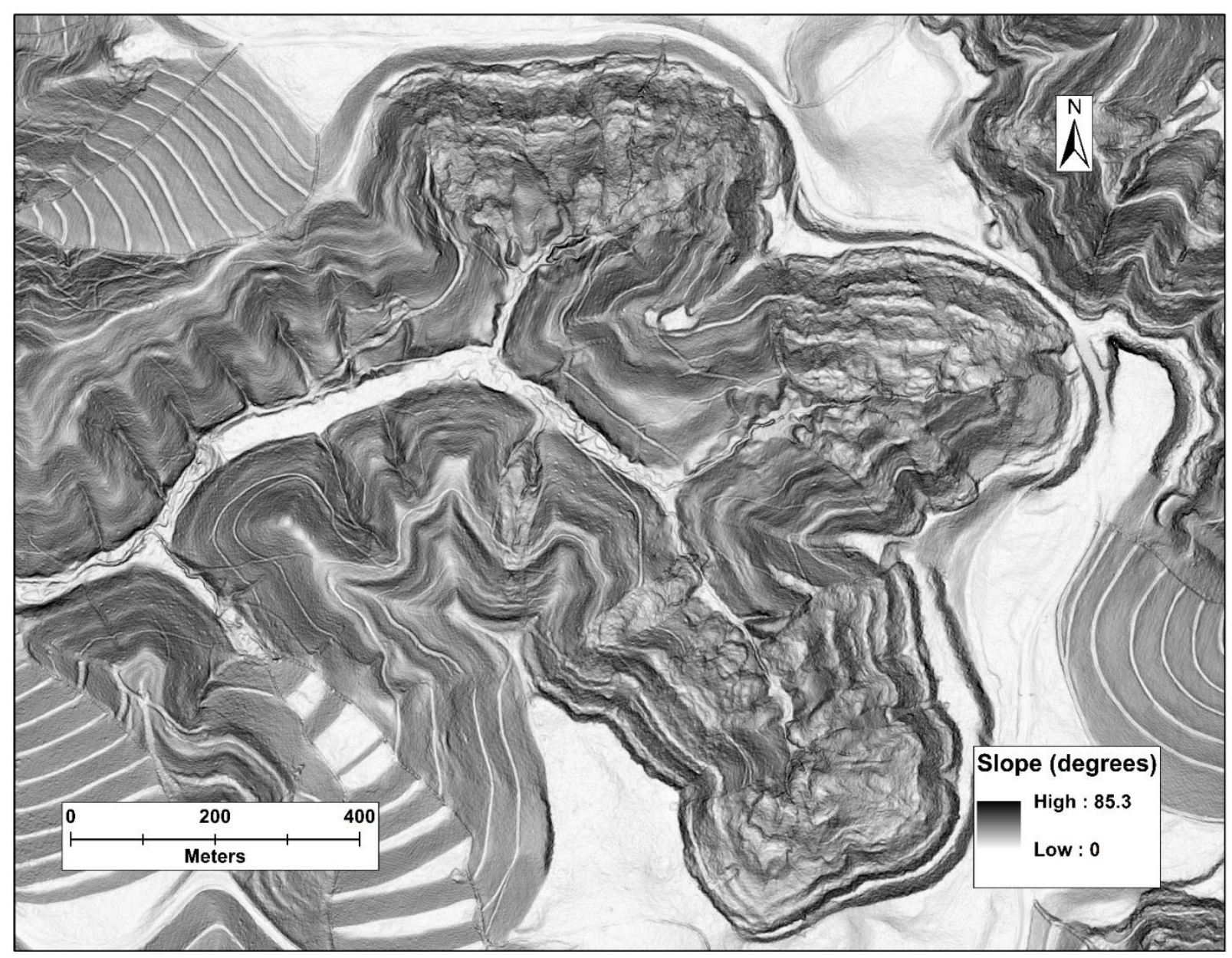

Figure 12. A $1 \mathrm{~m}$ LiDAR-derived slopeshade of pervasive landslide along the edges of a MTR/VF landscape in Kentucky. The landslides scallop the edges of backfill deposits, making them concurrent with mining. The image is from the Floyd-Pike dataset. 


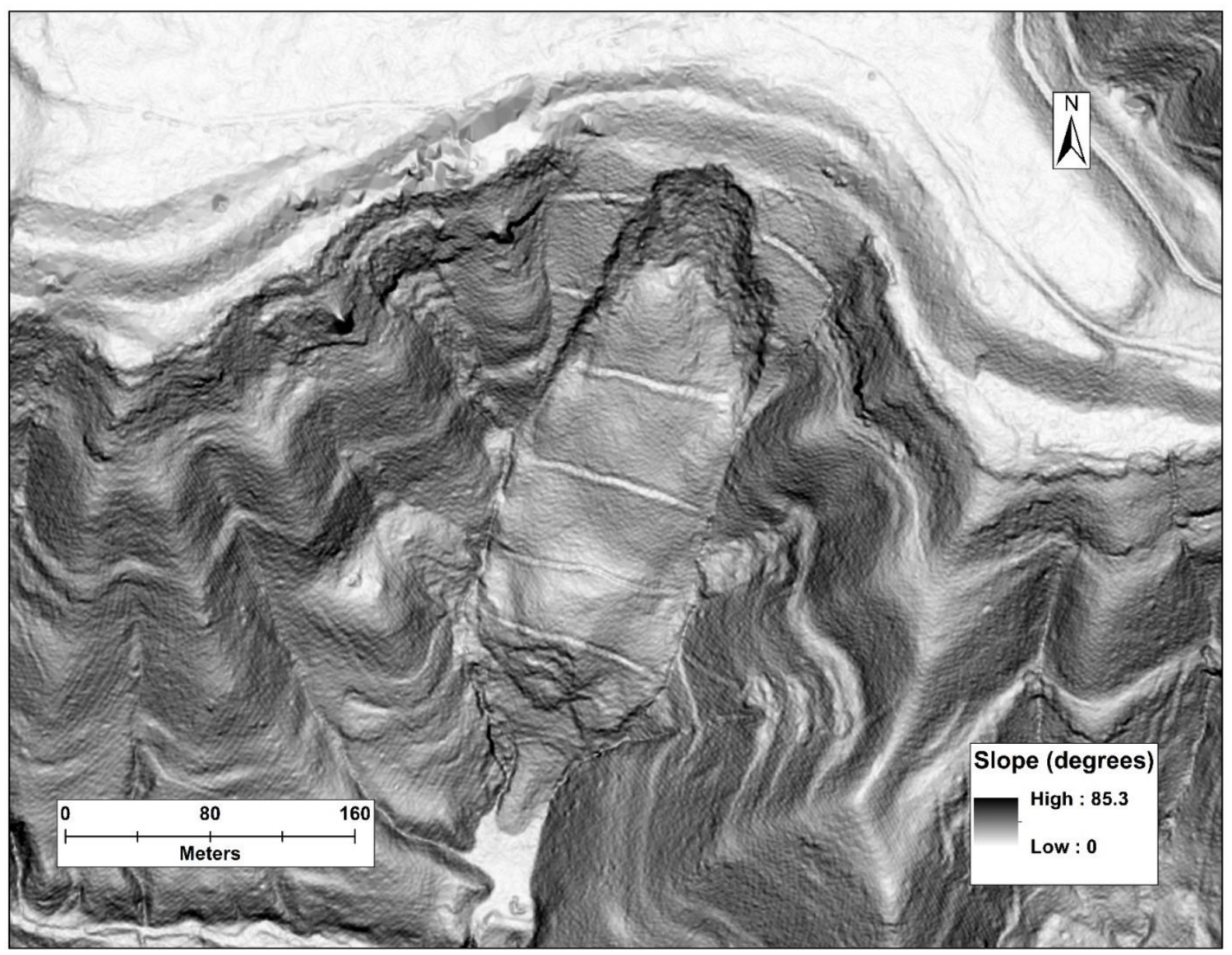

Figure 13. A $1 \mathrm{~m}$ LiDAR-derived slopeshade of landslide occurring within a valley fill in Kentucky. The maximum height of the landslide scarp is of the landslide is $\sim 44 \mathrm{~m}$. The image is from the Floyd-Pike dataset. 


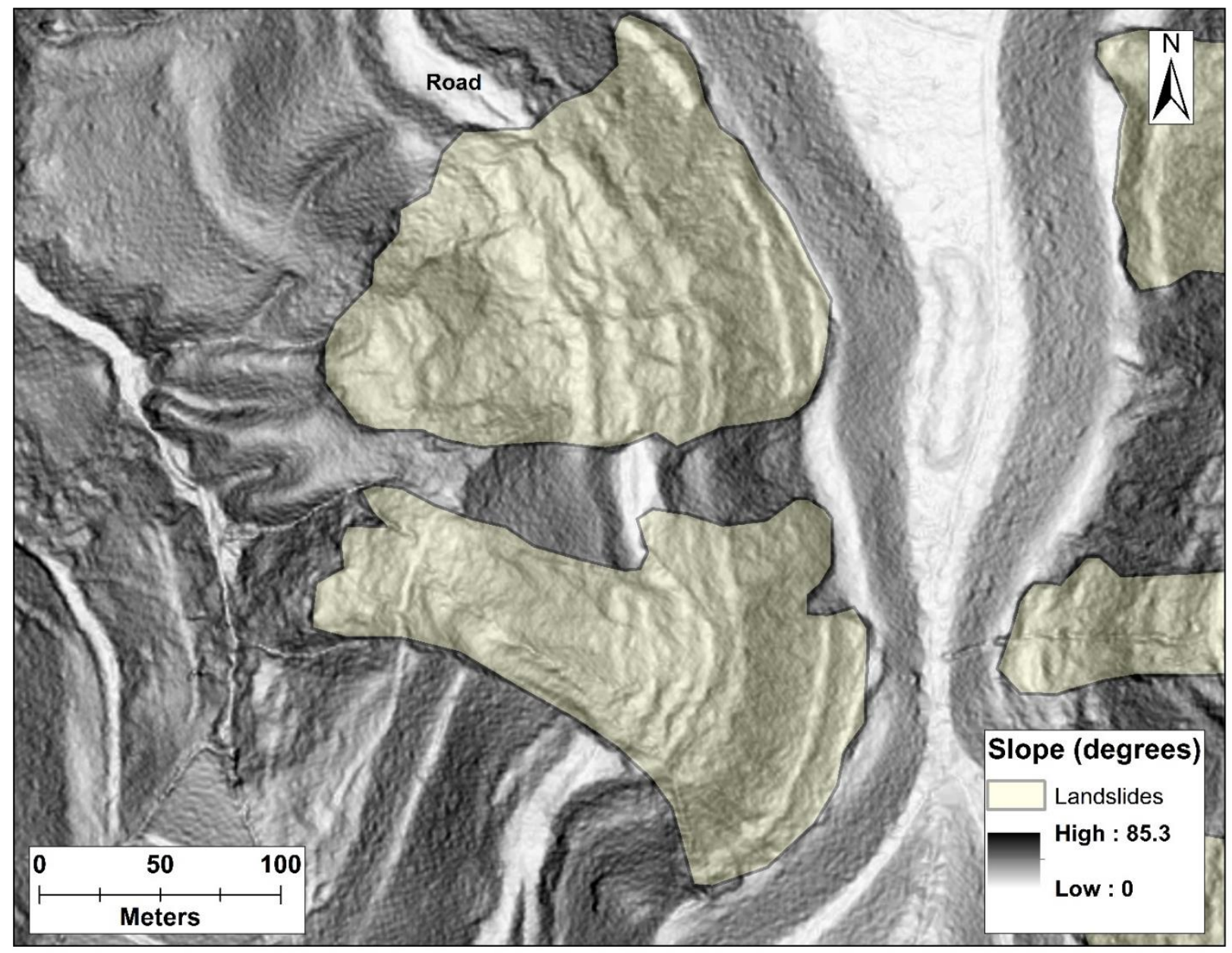

Figure 14. A $1 \mathrm{~m}$ LiDAR-derived slopeshade of several landslides covering a road on a MTR/VF landscape in Kentucky. The supposed landslide scarps and deposits are delineated in a transparent tan. The image is from the Floyd-Pike dataset. 


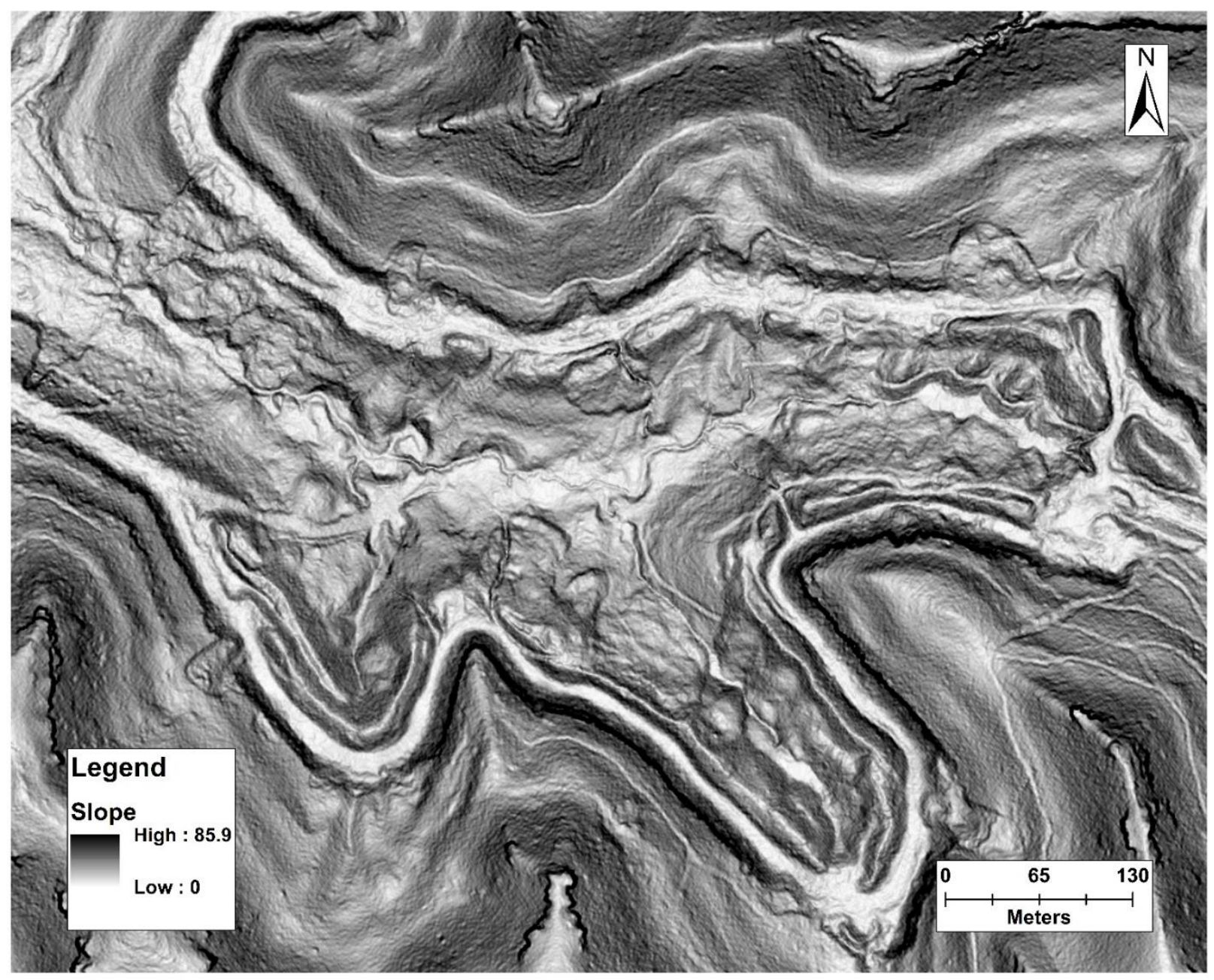

Figure 15. A 1 m LiDAR-derived slopeshade of widespread mass wasting associated with contour mining in Kentucky. Landslides in areas like this were not quantified. This image is from the PerryKnot-Breathitt dataset. 


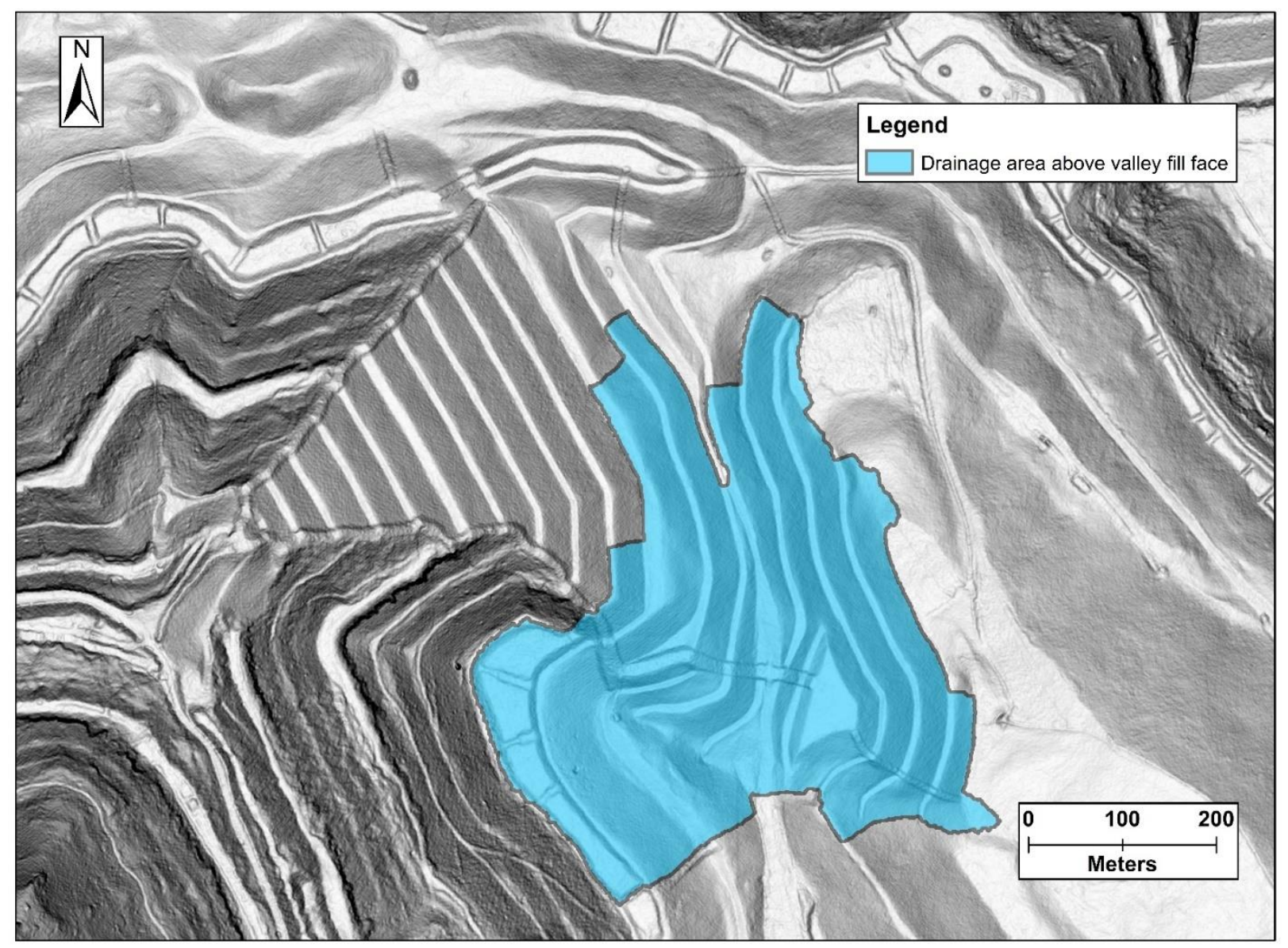

Figure 16. A $1 \mathrm{~m}$ LiDAR-derived hillshade showing the drainage area upslope (18.7 ha) of the constructed drain and most of the face on a valley fill near Amherstdale, West Virginia. This image illustrates the unusual levels of drainage area accumulation that can drain to steep slopes. The image is from the Amherstdale dataset. 


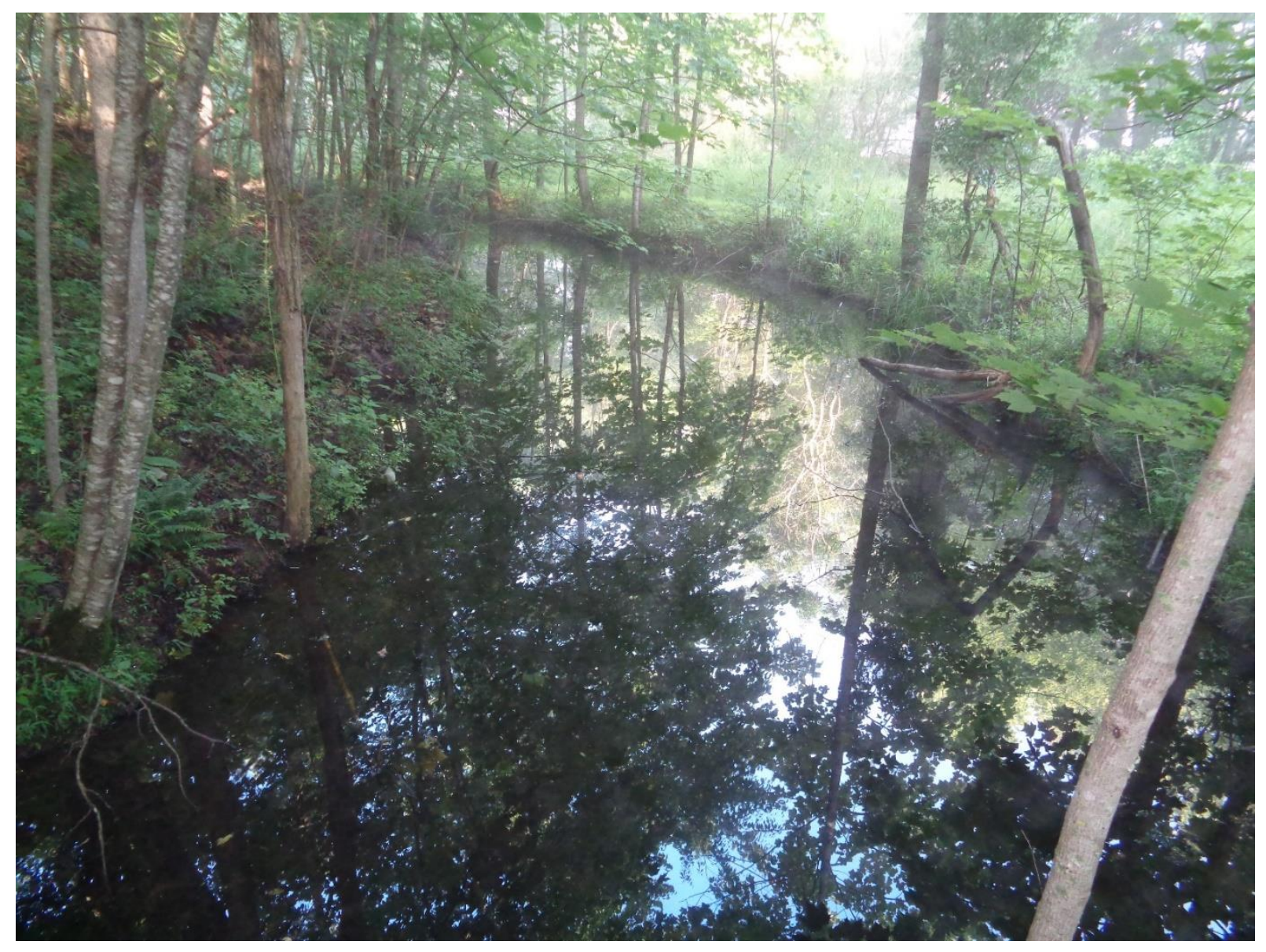

Figure 17. Water-filled retention cell located along a haul road within the Whitman West study area. The retention cell is $\sim 5 \mathrm{~m}$ wide and is located beside a slope of $\sim 30$ degrees with $130 \mathrm{~m}$ of relief. Retention cells can represent a substantial level of depression storage that is not seen in steep, natural catchments. 

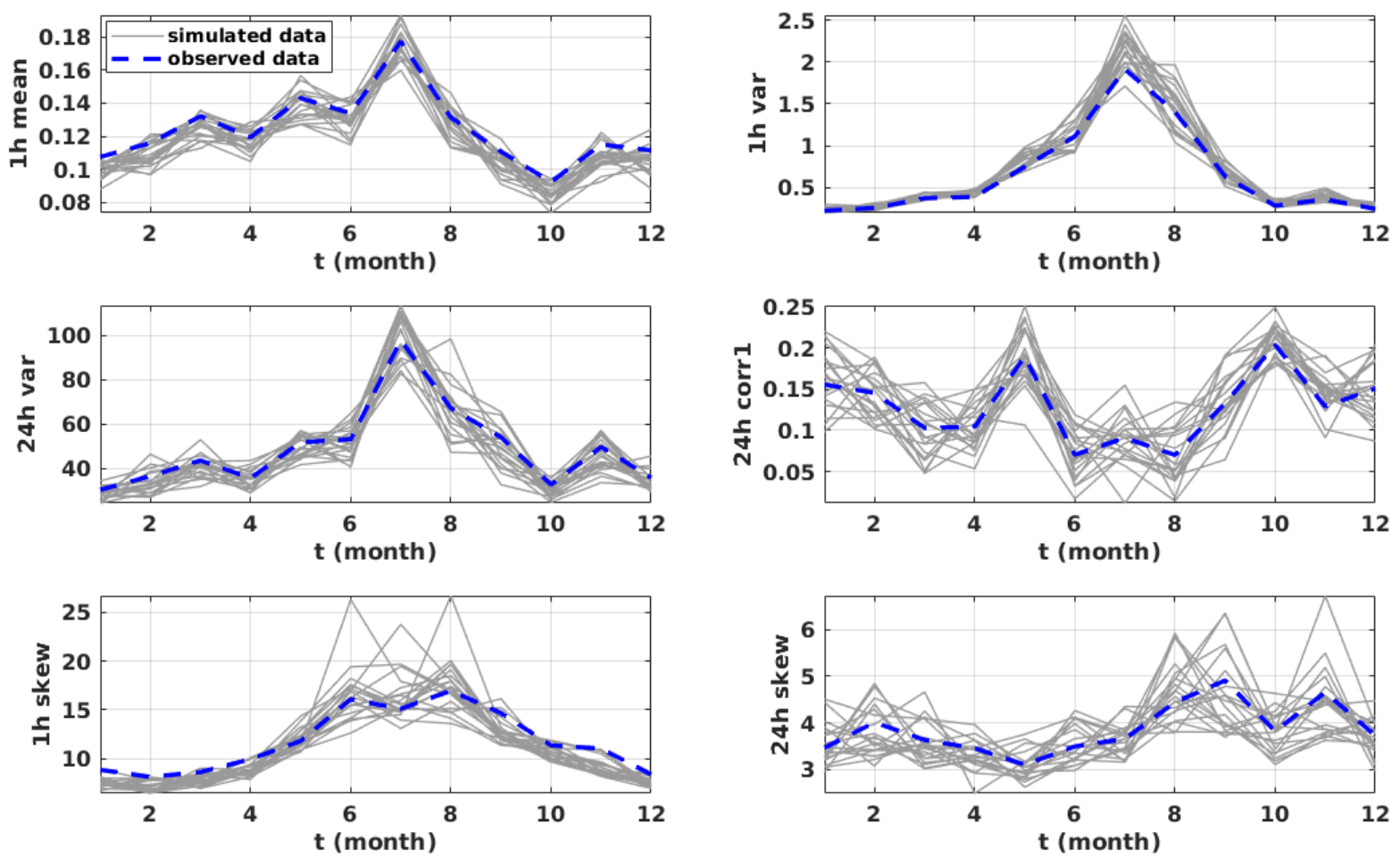

Figure 18. Statistics of hourly rainfall from a 62-year rainfall dataset from Charleston, West Virginia, and ten 100-year rainfall datasets based on the Charleston data created by the NSRP single-site rainfall generator from Brocca et al. (2013). 
1h Duration

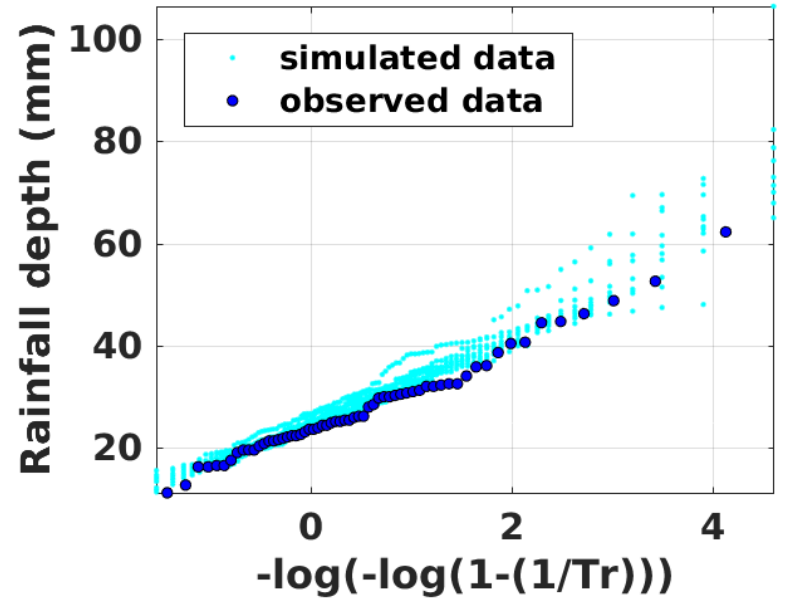

\section{2h Duration}

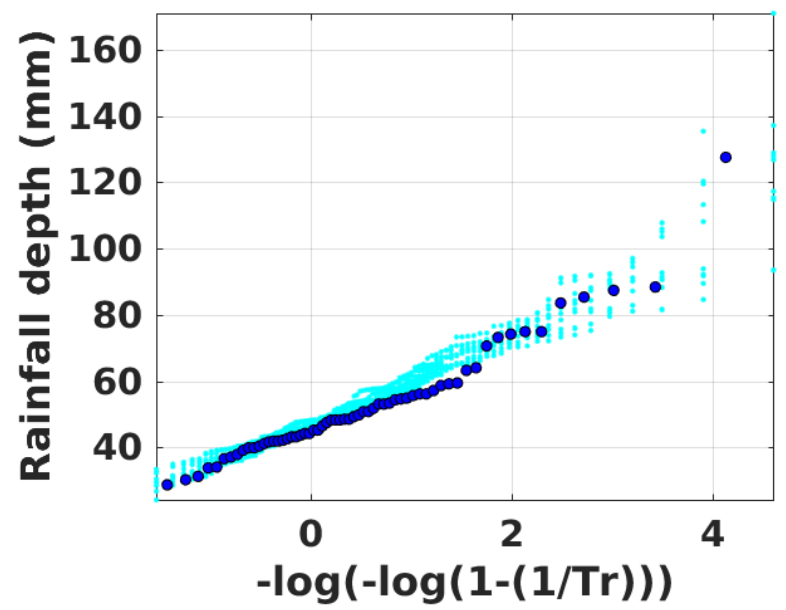

6h Duration
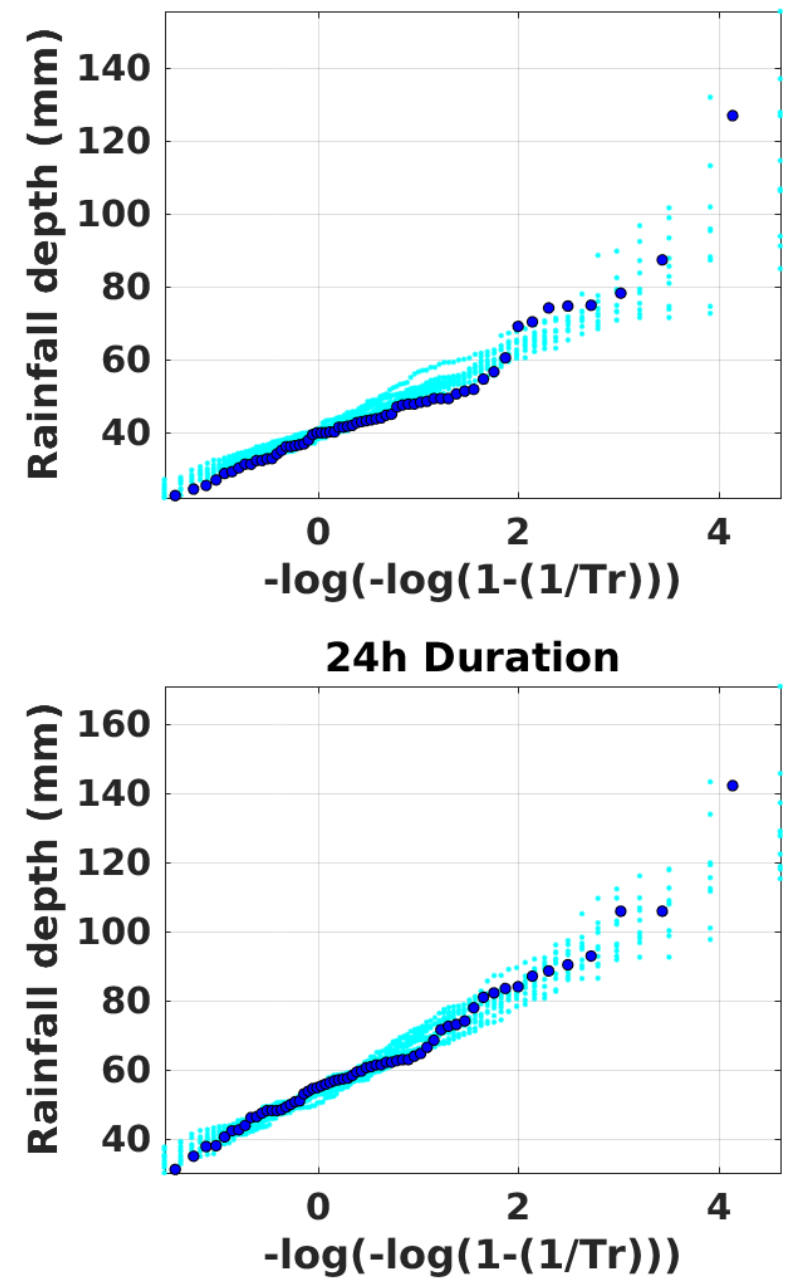

Figure 19. Magnitude-frequency comparison of hourly rainfall data from Charleston, West Virginia, and the rainfall data created by the rainfall generator of Brocca et al. (2013). A 100-year event would plot at 2.36 on the $\mathrm{x}$-axis. 


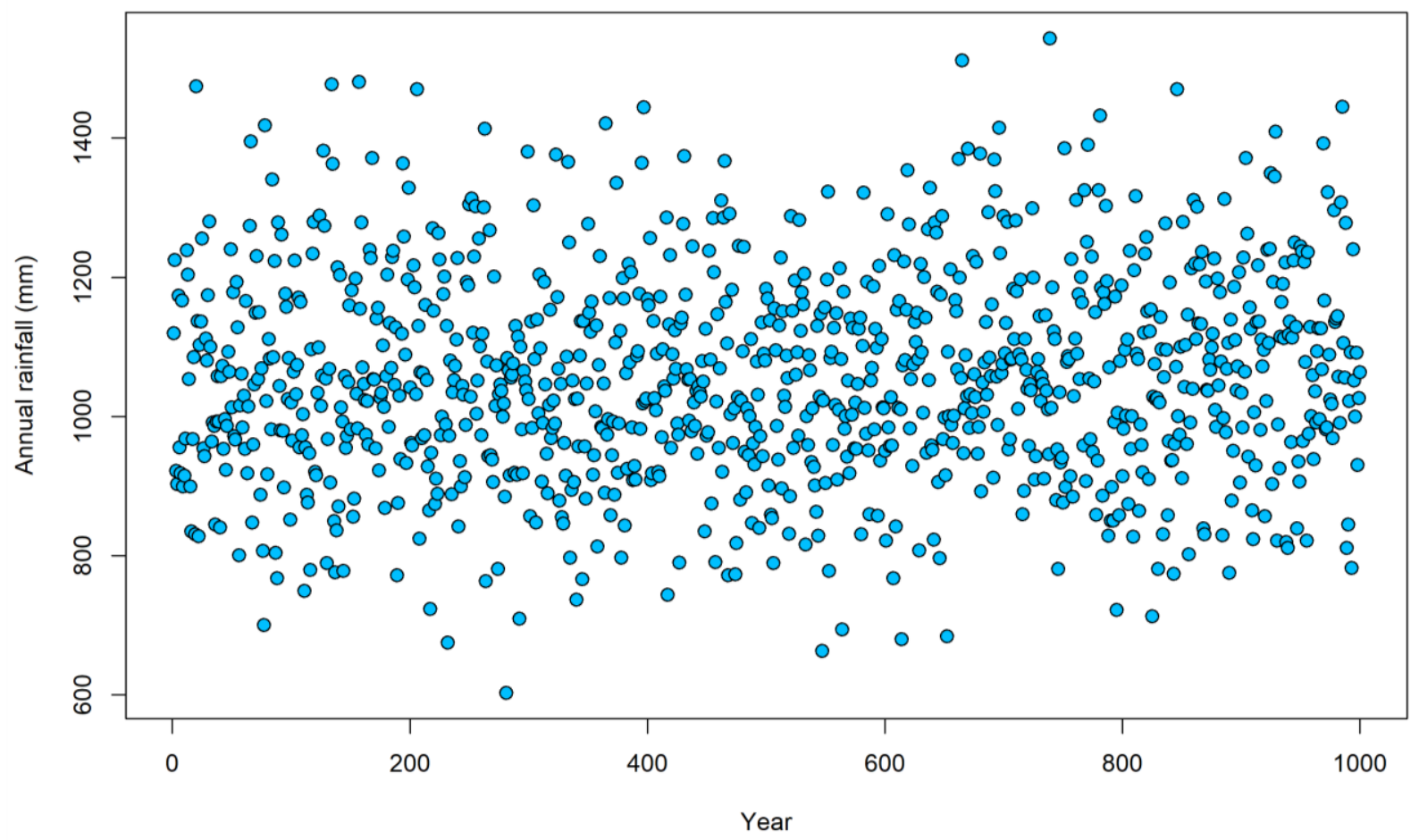

Figure 20. Annual rainfall for the generated 1000-year dataset used to drive the CAESAR-Lisflood landscape evolution model. 


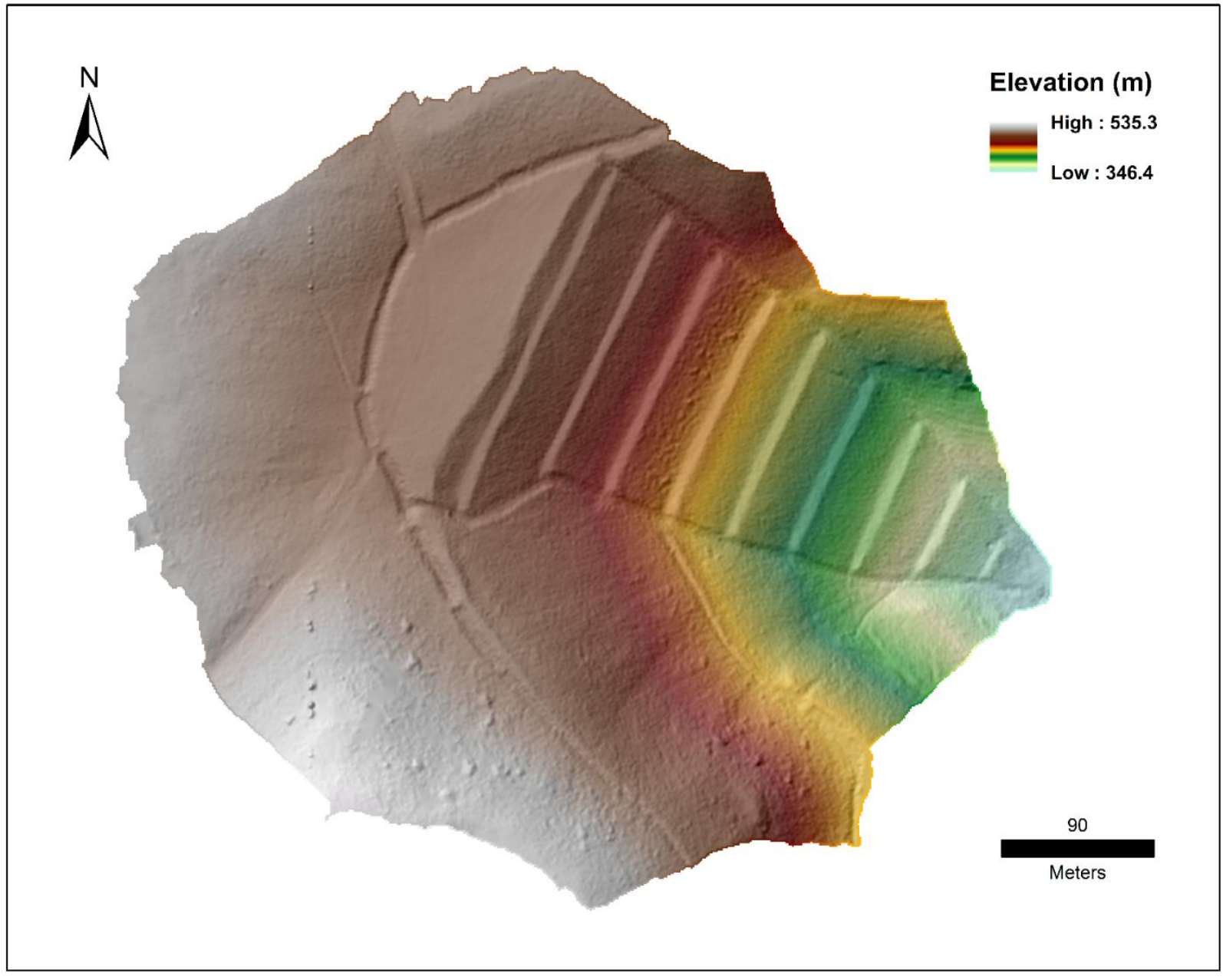

Figure 21. A 1 m LiDAR-derived transparent hillshade over DEM of Whitman \#8 catchment.

Catchment was delineated in ArcMap using the D8 algorithm. Three CAESAR-Lisflood modeling runs of 1000 years for 3 different grain size scenarios were conducted using this DEM as input topography. Six 500-yr modeling runs were performed using this DEM to test the sensitivity of CAESAR-Lisflood to Manning's $n$, vegetational shear stress (Pa), and the TOPMODEL $m$ parameter. 


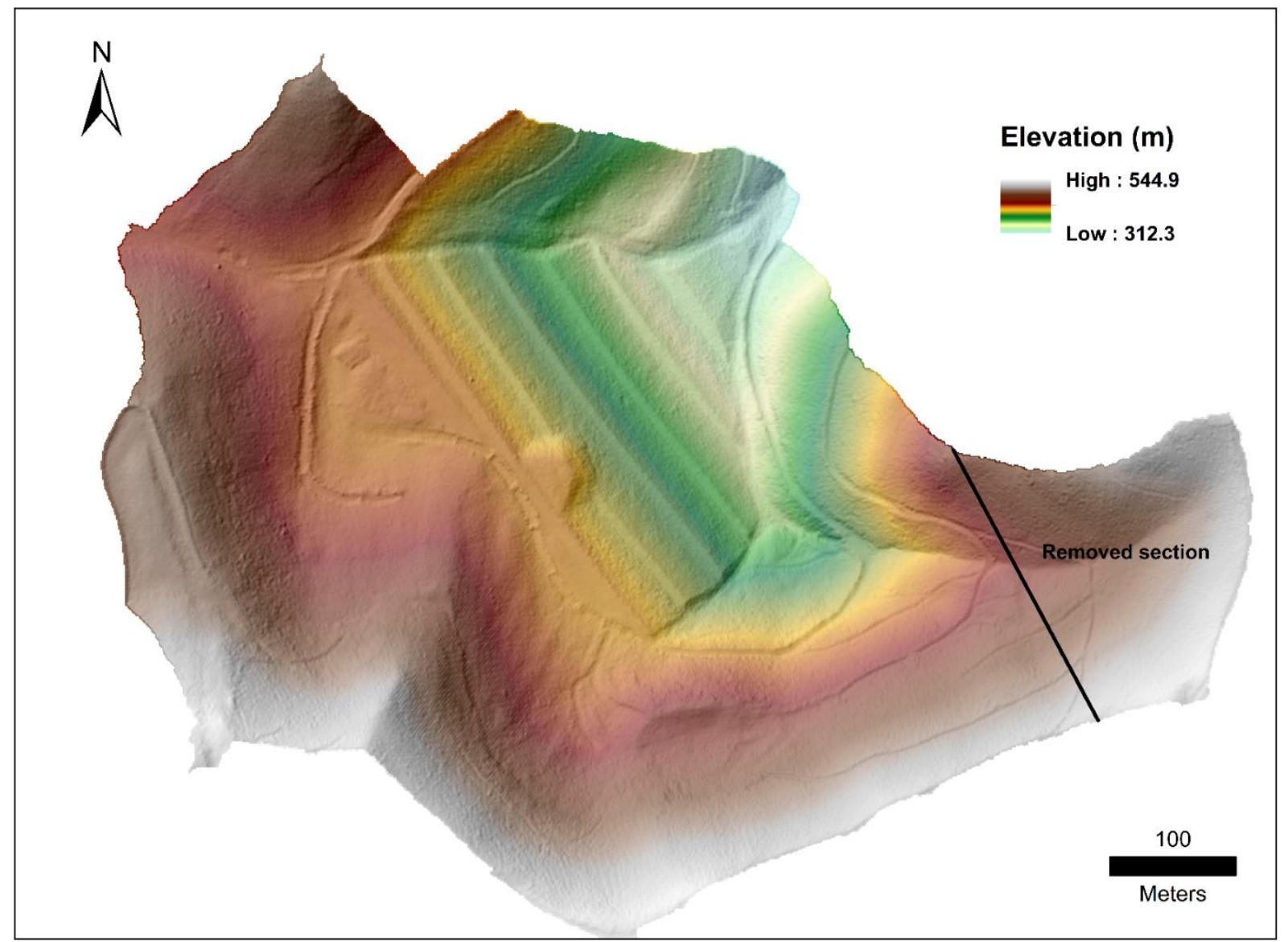

Figure 22. A $1 \mathrm{~m}$ LiDAR-derived transparent hillshade over DEM of Whitman \#18 catchment. A portion of the catchment area was removed as it extended beyond the lowest point (outlet) of the catchment, which does not allow for proper functioning of the CAESAR-Lisflood landscape evolution model. Three CAESAR-Lisflood modeling runs of 1000 years for 3 different grain size scenarios were conducted using this DEM as input topography. 


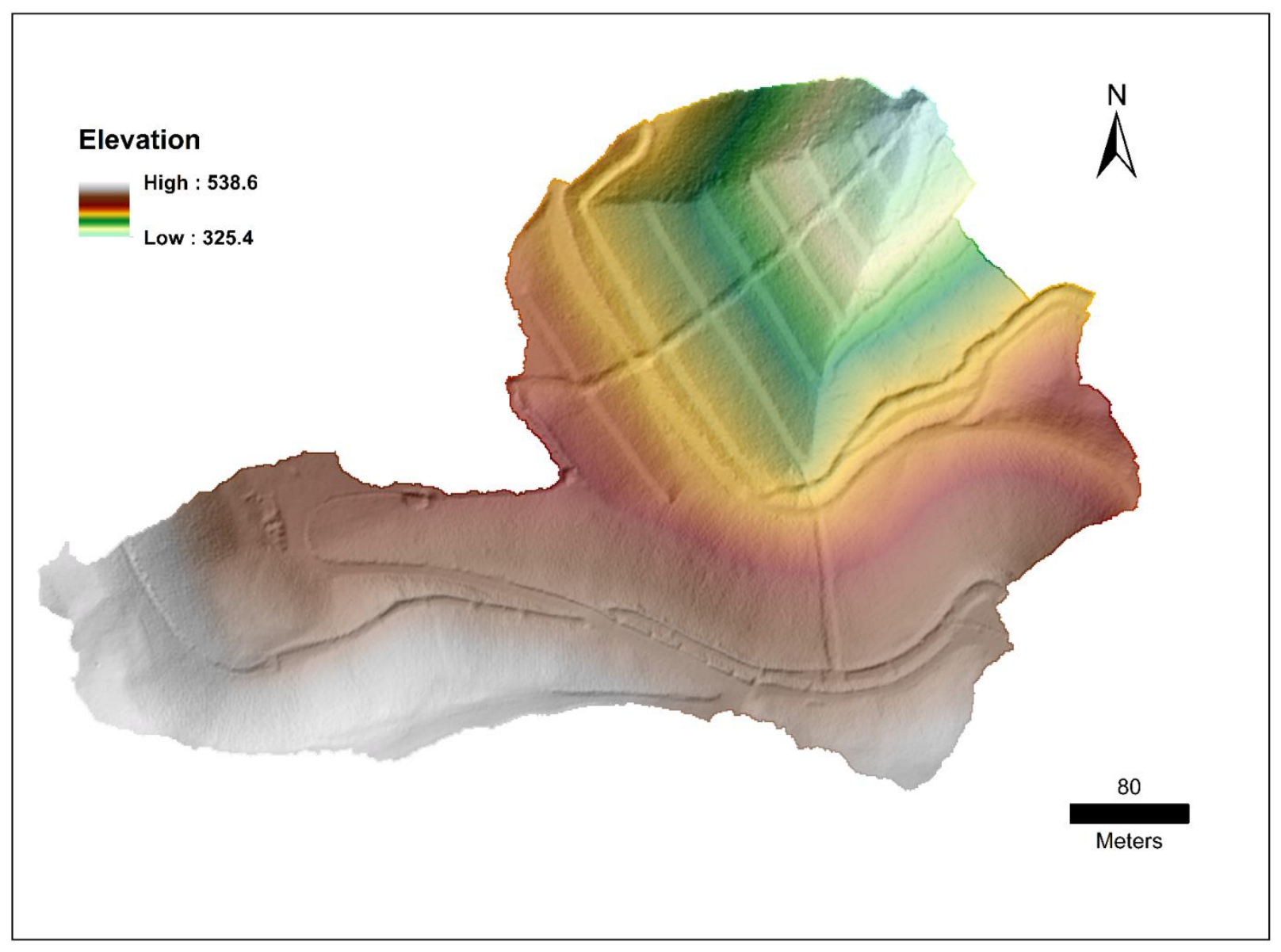

Figure 23. $1 \mathrm{~m}$ LiDAR-derived transparent hillshade over DEM of Whitman \#20 catchment. Three CAESAR-Lisflood modeling runs of 1000 years for 3 different grain size scenarios were conducted using this DEM as input topography. 


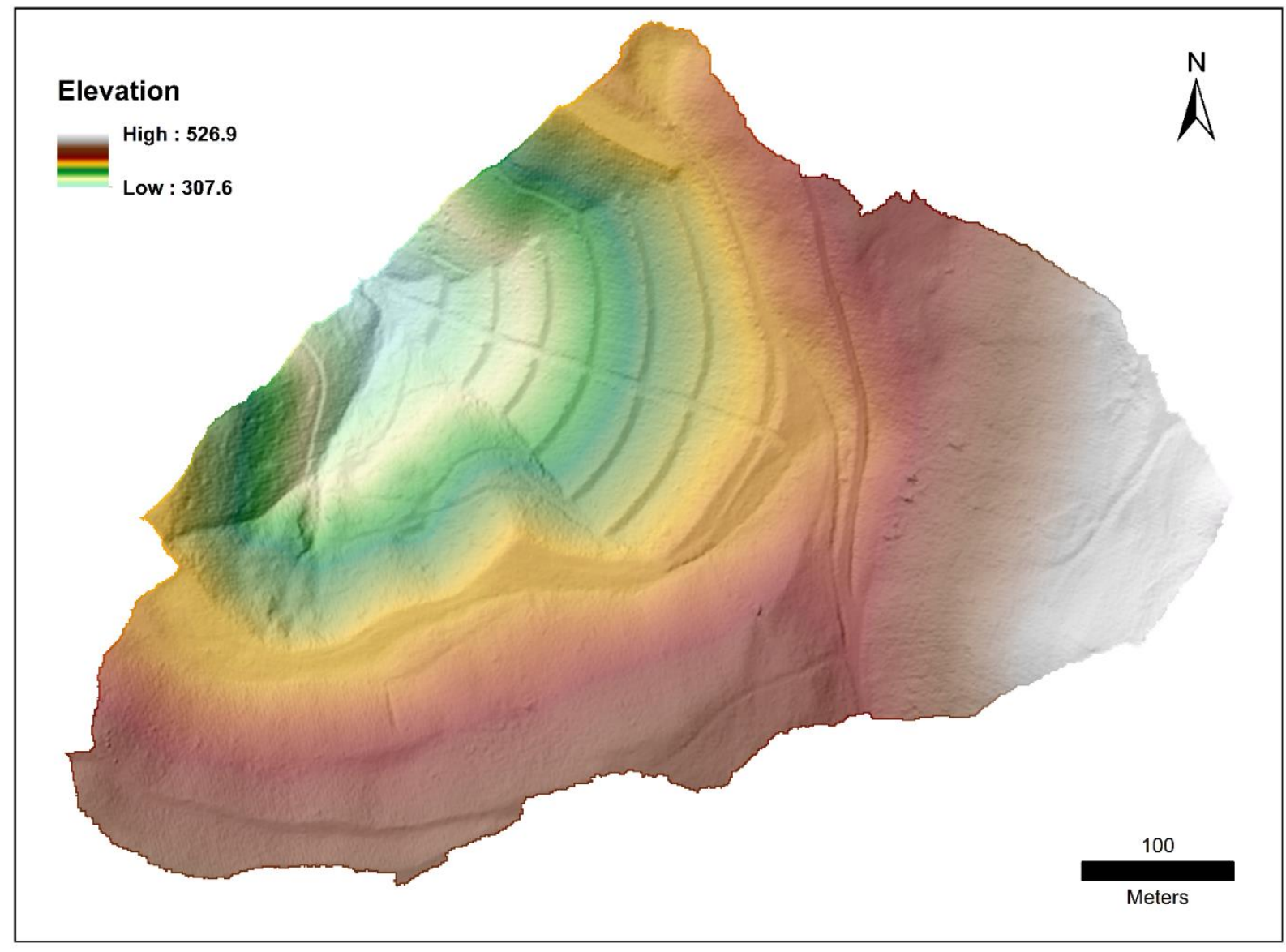

Figure 24. A 1 m LiDAR-derived transparent hillshade over DEM of the Scarlet \#1 catchment. Scarlet $\# 1$ is $2.5 \mathrm{~km}$ SE of the field study areas. Three CAESAR-Lisflood modeling runs of 1000 years for 3 different grain size scenarios were conducted using this DEM as input topography. 


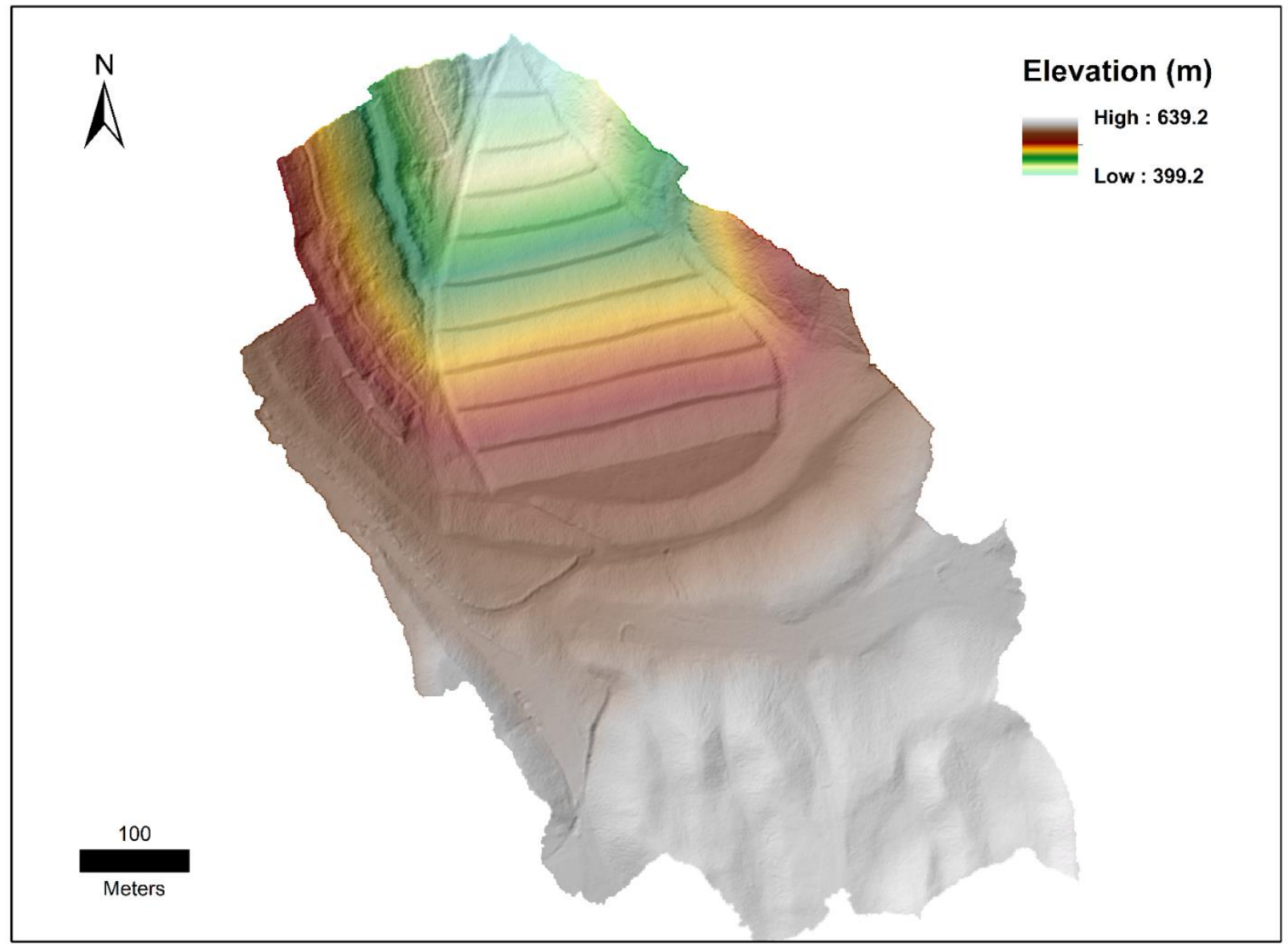

Figure 25. A 1 m LiDAR-derived transparent hillshade of Boone-Kanawha-Raleigh \#1 catchment. Three CAESAR-Lisflood modeling runs of 1000 years for 3 different grain size scenarios were conducted using this DEM as input topography. 


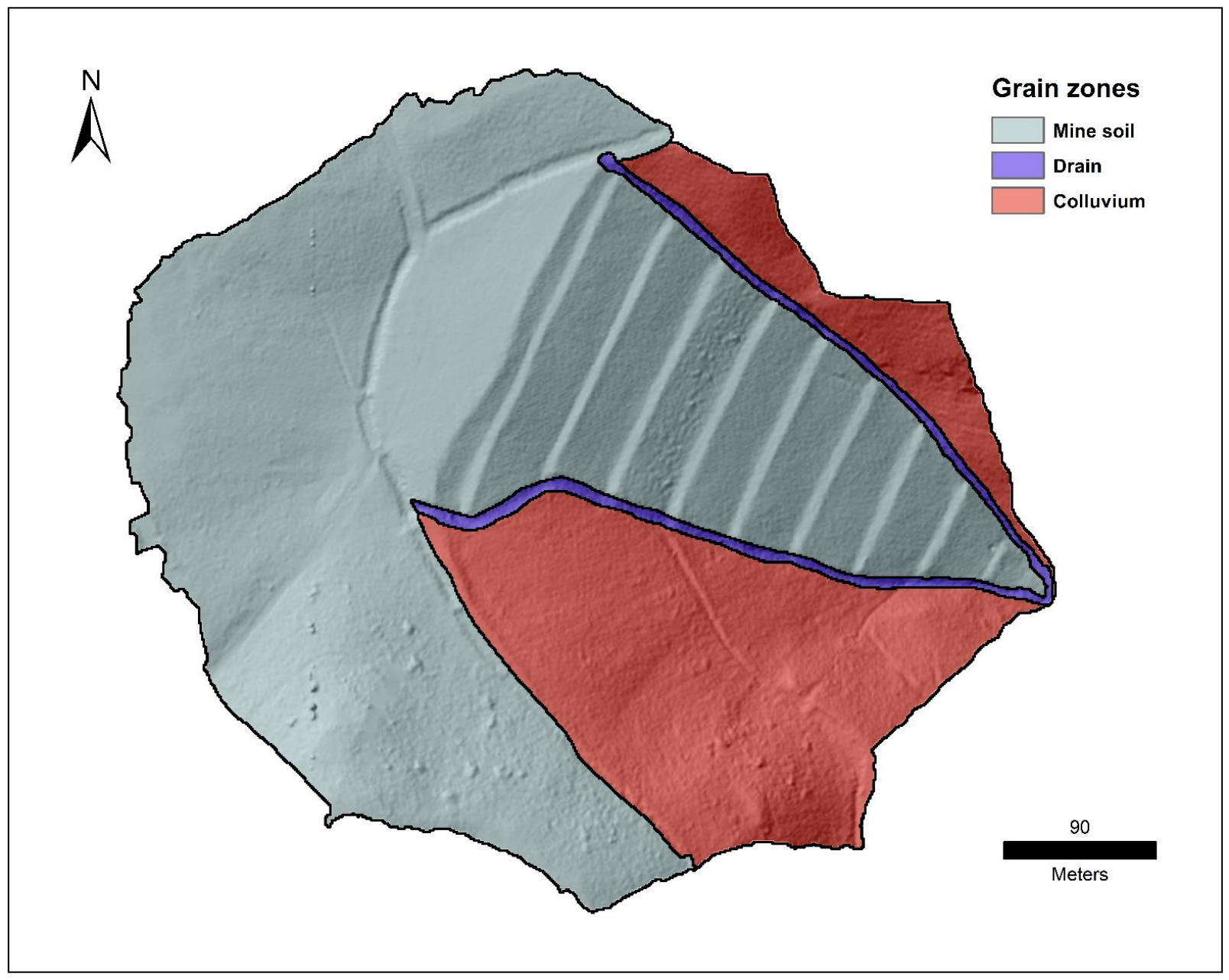

Figure 26. Transparent grain zones over a $1 \mathrm{~m}$ hillshade of Whitman \#8 catchment used in CAESARLisflood landscape evolution modeling. Each zone has a unique grain size distribution which attempts to simulate generic field conditions. Two meters below the mine soil and drain zones is another grain size zone, which represents the bulk of the valley fill. 


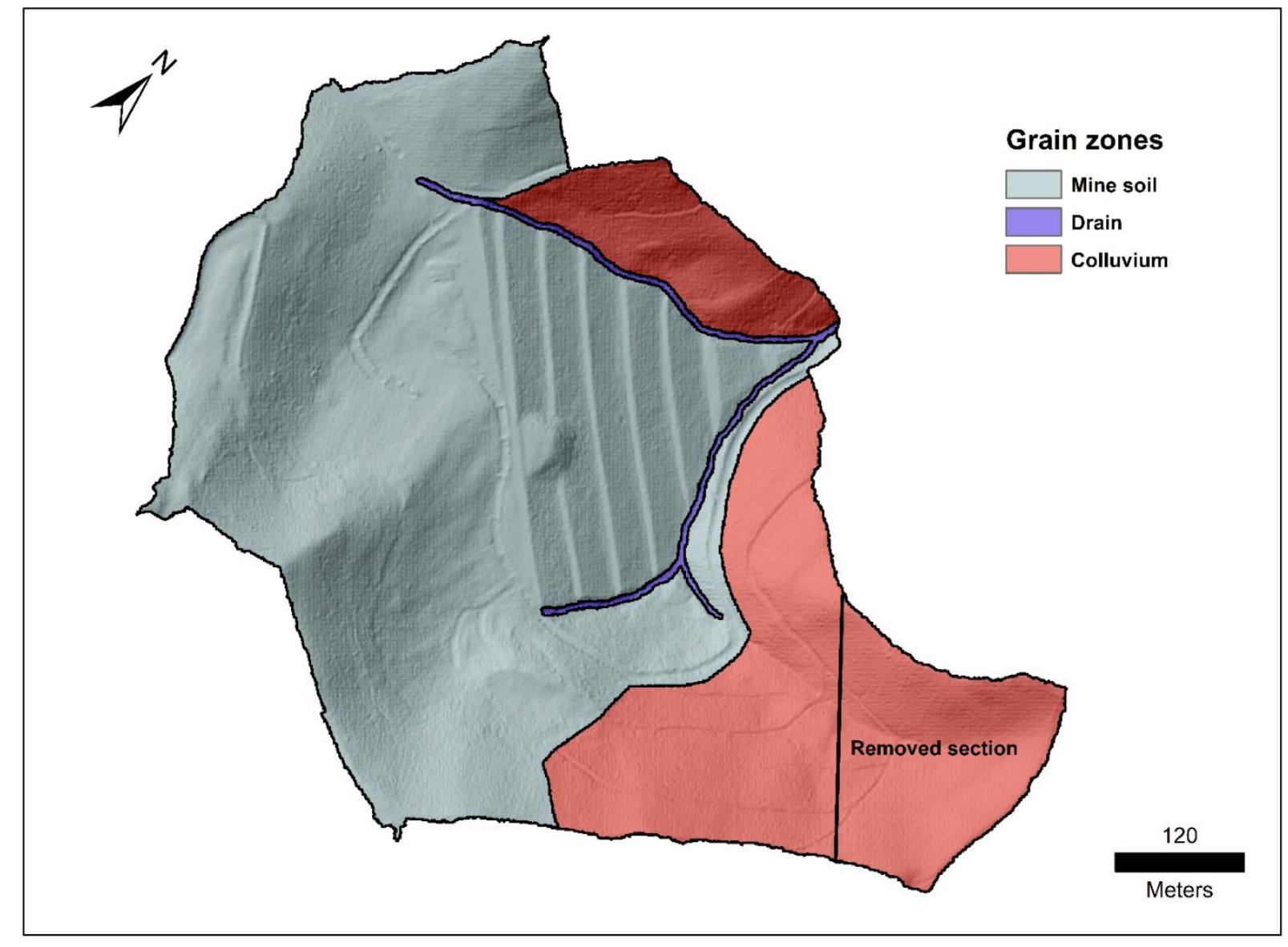

Figure 27. Transparent grain size zones over $1 \mathrm{~m}$ LiDAR-derived hillshade of the Whitman \#18 catchment used in CAESAR-Lisflood landscape evolution modeling. A section of the catchment was removed for the DEM to have zero NoData pixels beyond the outlet of the catchment. The tilted North arrow indicates that this catchment had to be rotated $45^{\circ}$ to decrease drainage area removal. 


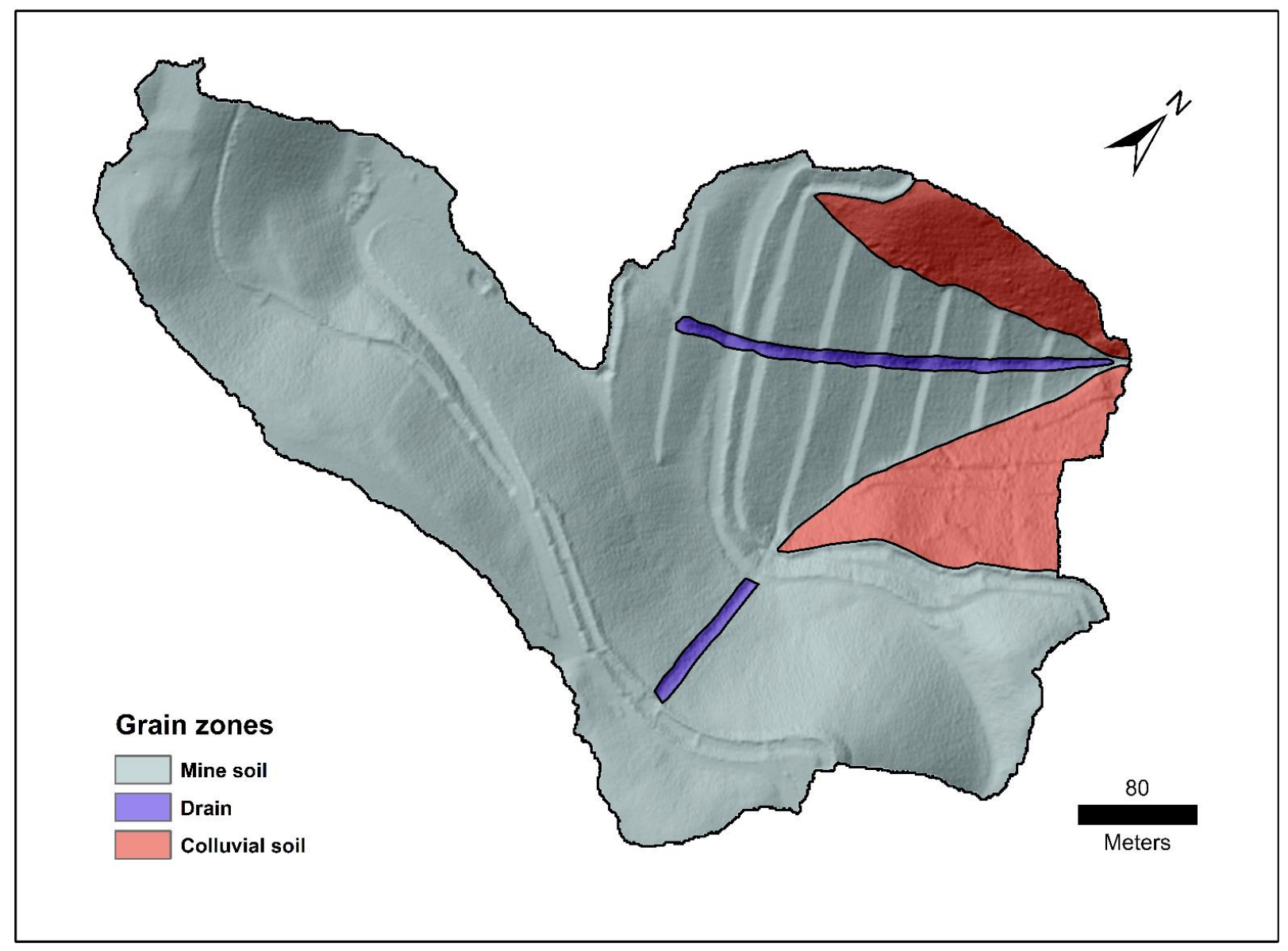

Figure 28. Transparent grain zones over $1 \mathrm{~m}$ LiDAR-derived hillshade of the Whitman \#20 catchment. This catchment was rotated $45^{\circ}$ to minimize drainage area reduction. Each grain size zone has a unique distribution of the same 9 grain sizes $(0.5,1,4,8,32,64,256,512$, and $2048 \mathrm{~mm})$. 


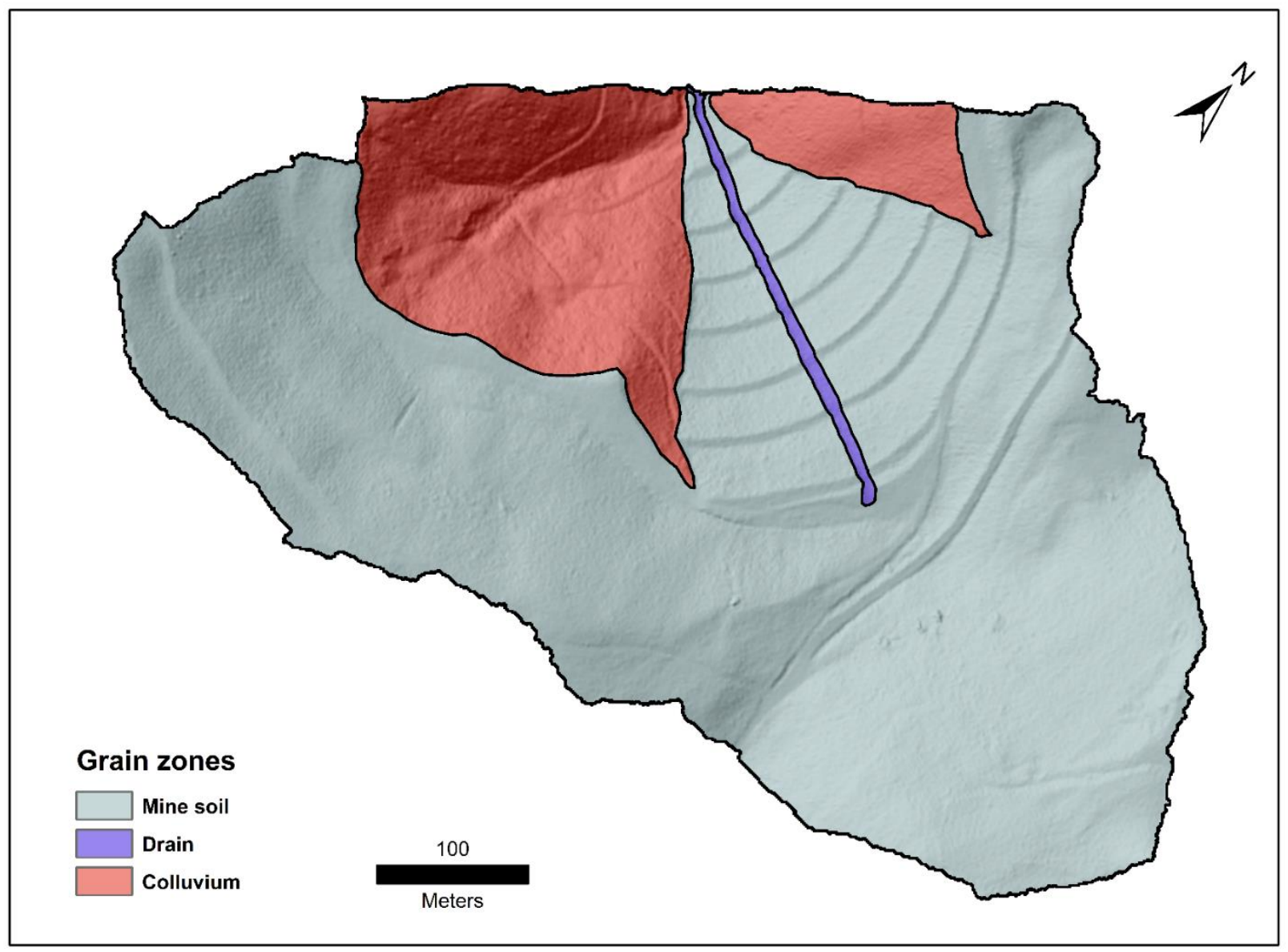

Figure 29. Transparent grain zones over $1 \mathrm{~m} \mathrm{LiDAR-derived} \mathrm{hillshade} \mathrm{of} \mathrm{the} \mathrm{Scarlet} \mathrm{\# 1} \mathrm{catchment.} \mathrm{The}$ DEM has been rotated $45^{\circ}$ to minimize drainage area. The grain size zones mimicked the expected valley-filled catchment grain size distributions to better model landscape trajectory. 


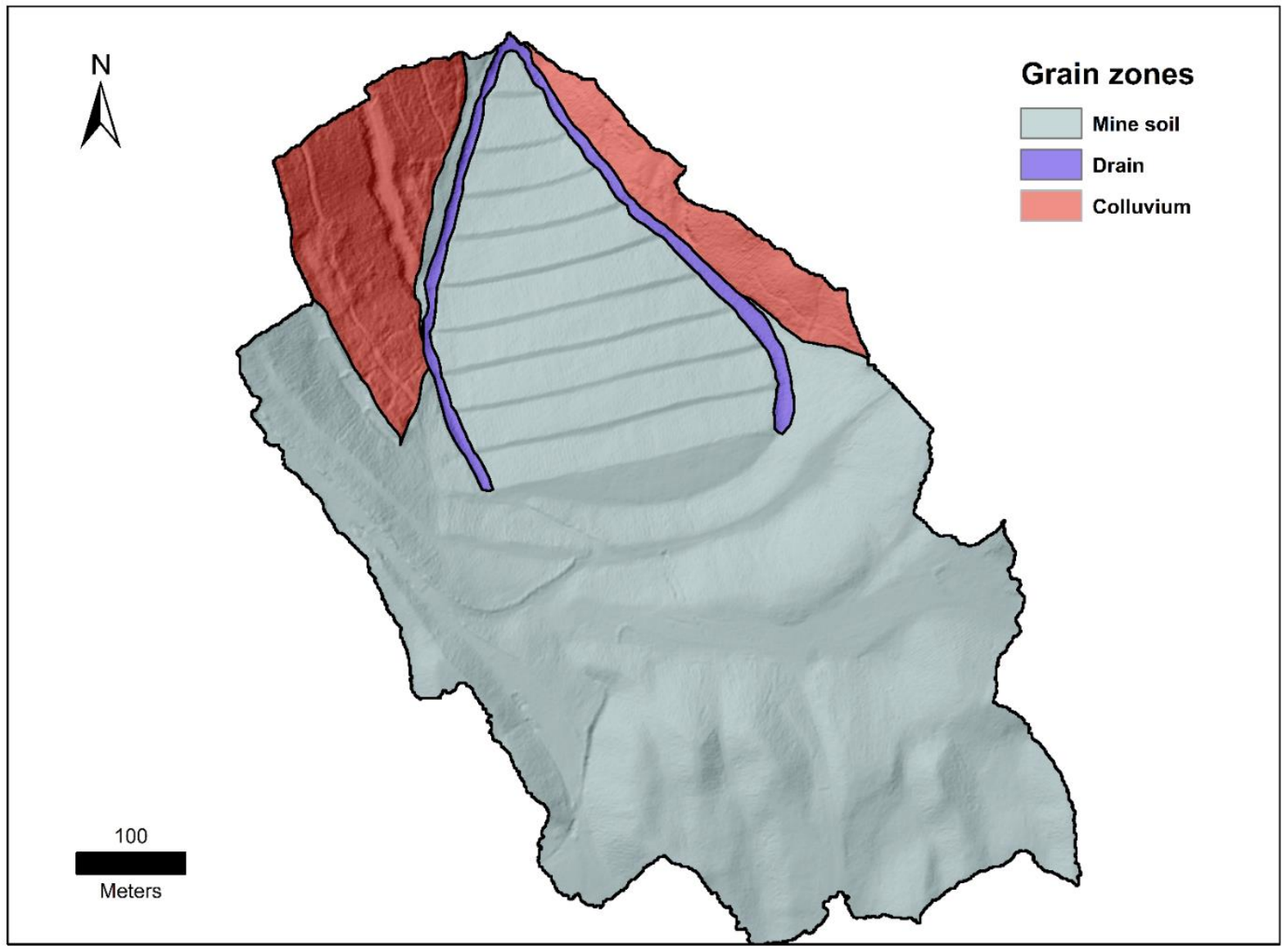

Figure 30. Transparent grain zones over $1 \mathrm{~m}$ hillshade of Boone-Kanawha Raleigh \#1 catchment. 


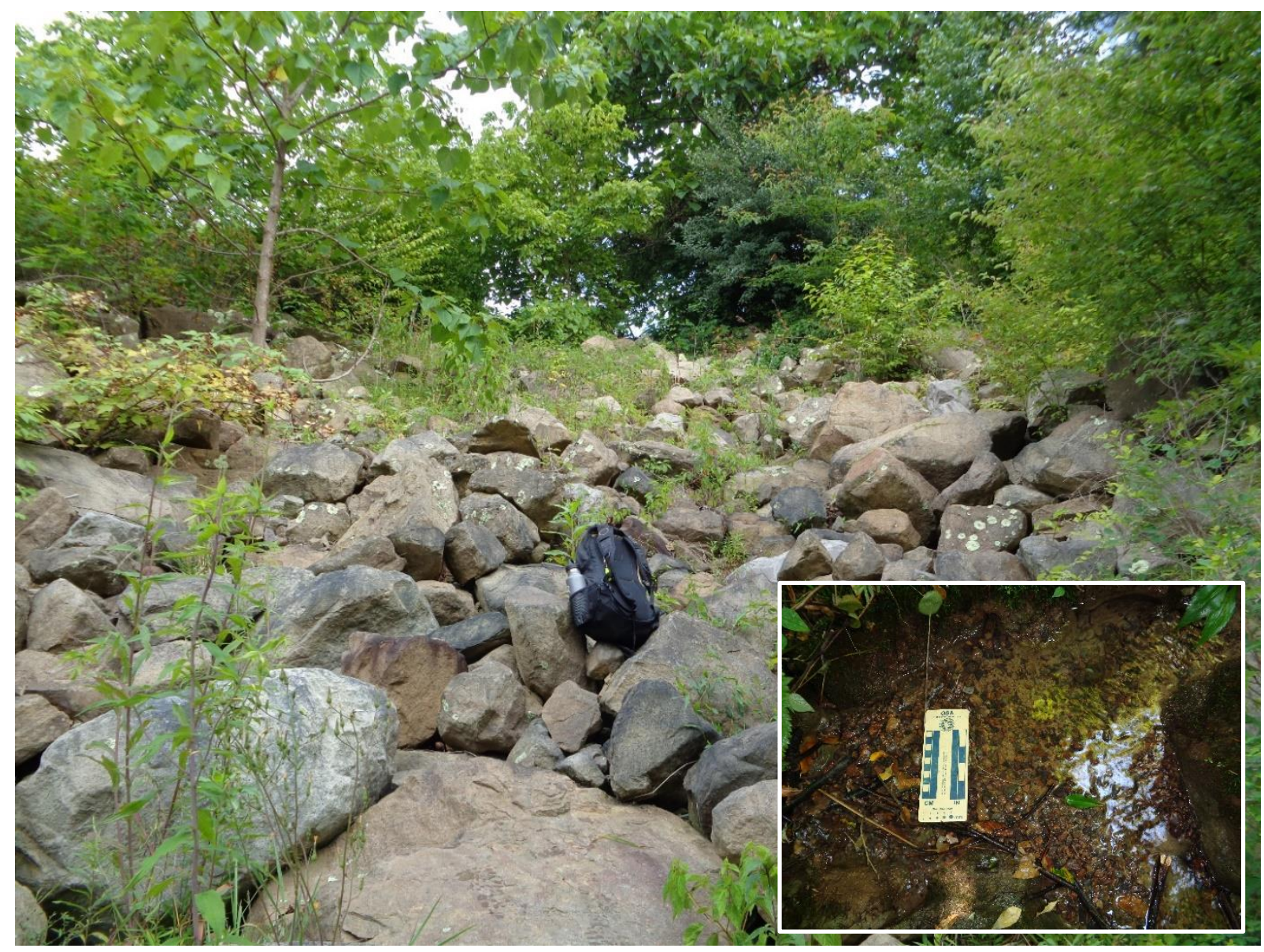

Figure 31. Constructed center drain of the Whitman \#19 valley fill is mainly composed of boulders (backpack for scale). Inset: Finer sediments present within fluvial channel within the constructed drain. Twenty percent of the constructed was estimated to be finer than boulder size $(<=256 \mathrm{~mm}$ ) based on field observations. Field photo guide is $10 \mathrm{~cm}$ in length. 

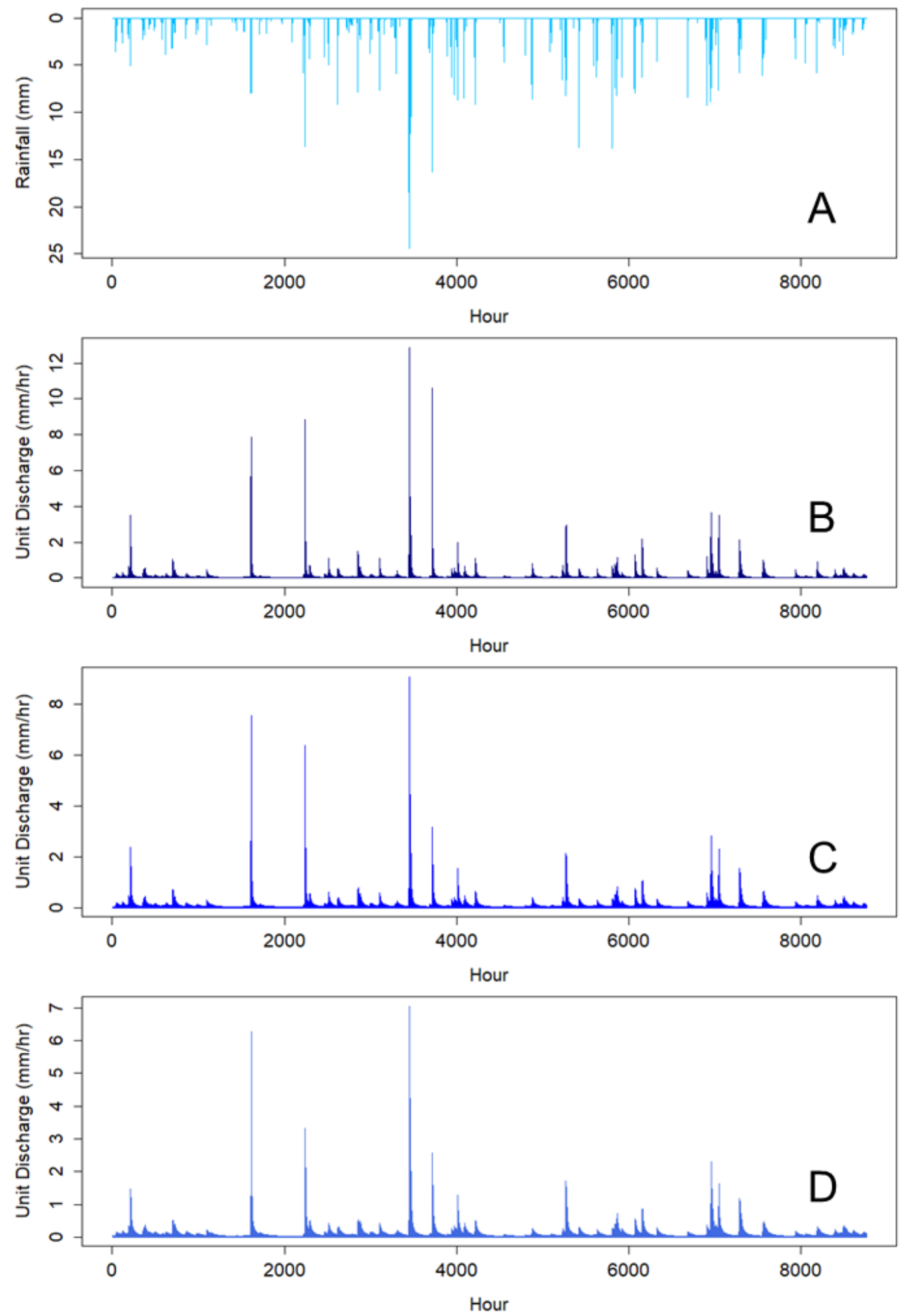

Figure 32. Comparison between generated rainfall and 3 CAESAR-Lisflood modeled discharge data for year 43 of 200-year runs. A) Year 43 of NSRP generated rainfall dataset based on Charleston, West Virginia, rainfall. B-D) Year 43 hydrograph from CAESAR-Lisflood model runs with different values of 0.005 (B), 0.007 (C), and 0.009 (D). A value of 0.007 was determined to better capture the flood peaks exhibited in Fig. 35. 


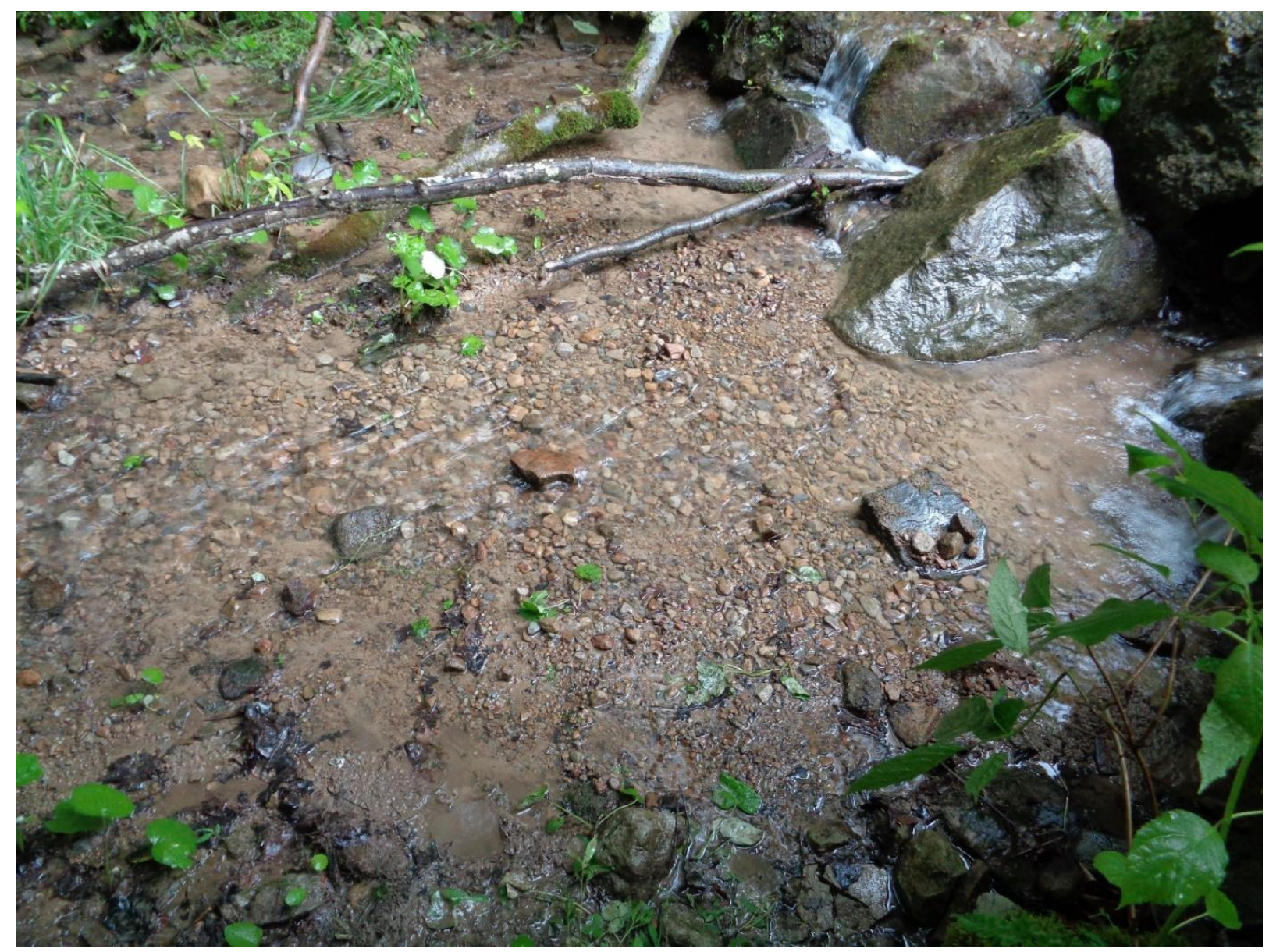

Figure 33. Outlet stream of the Whitman \#18 catchment. The fluvial channels within constructed drains near the toes of valley fills and the outlet streams were seen to be mostly clear of vegetation. CAESARLisflood can model a vegetated landscape where little erosion occurs unless a threshold shear stress is crossed (Howard, 1999). Values of vegetational critical shear stress greater than $40 \mathrm{~Pa}$ were seen to be too high, as vegetation was unrealistically modeled to completely cover the drains and the outlet. 


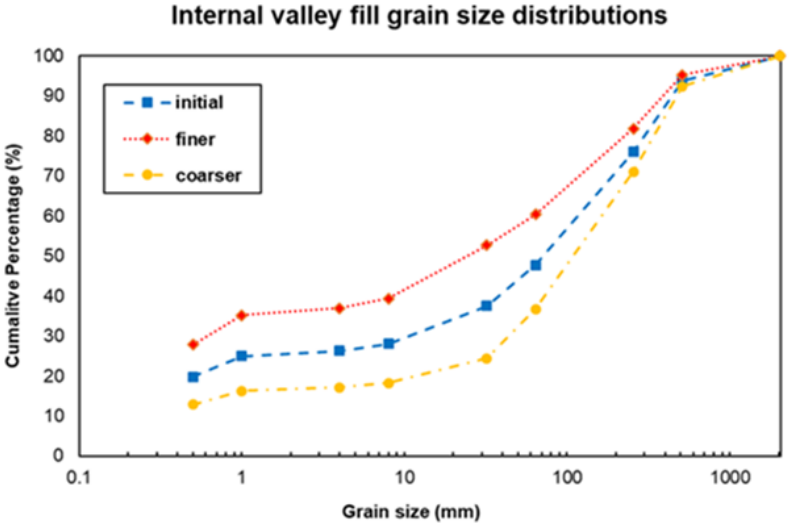

Mine soil grain size distributions

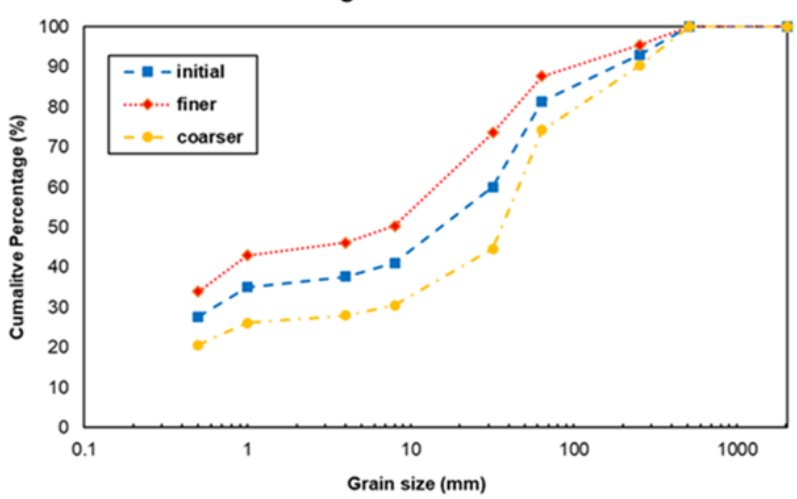

Valley fill drain grain size distributions

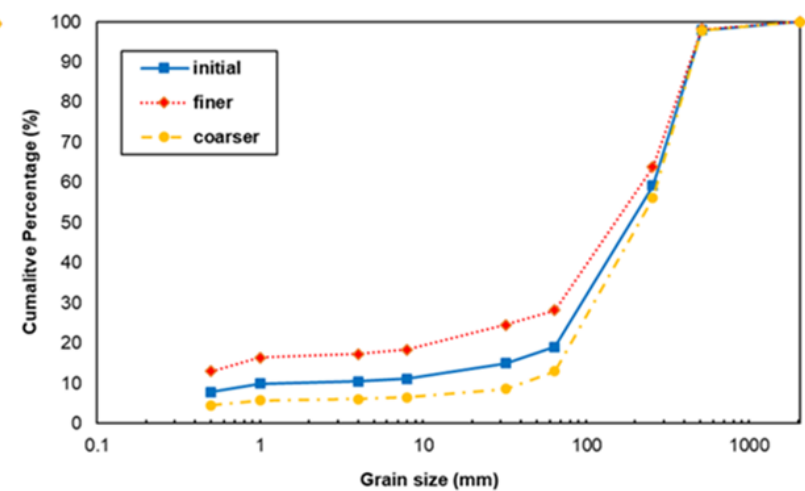

Colluvial soil grain size distributions

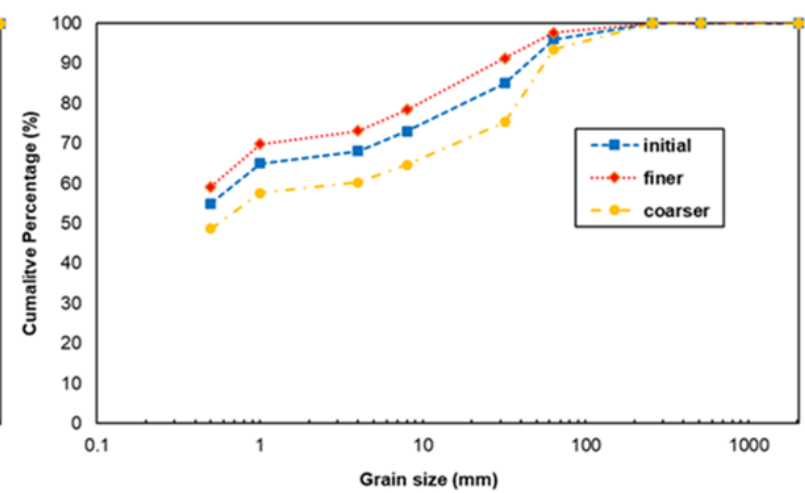

Figure 34. Grain size distributions for grain size zones for all CAESAR-Lisflood modeled grain size scenarios. Three different grain size scenarios were used in the 1000-year model runs as grain size distribution was thought to be the parameter that may vary the most. The finer and coarser grain size distributions were made from the initial distribution using a technique similar to Skinner and Coulthard (2017). 


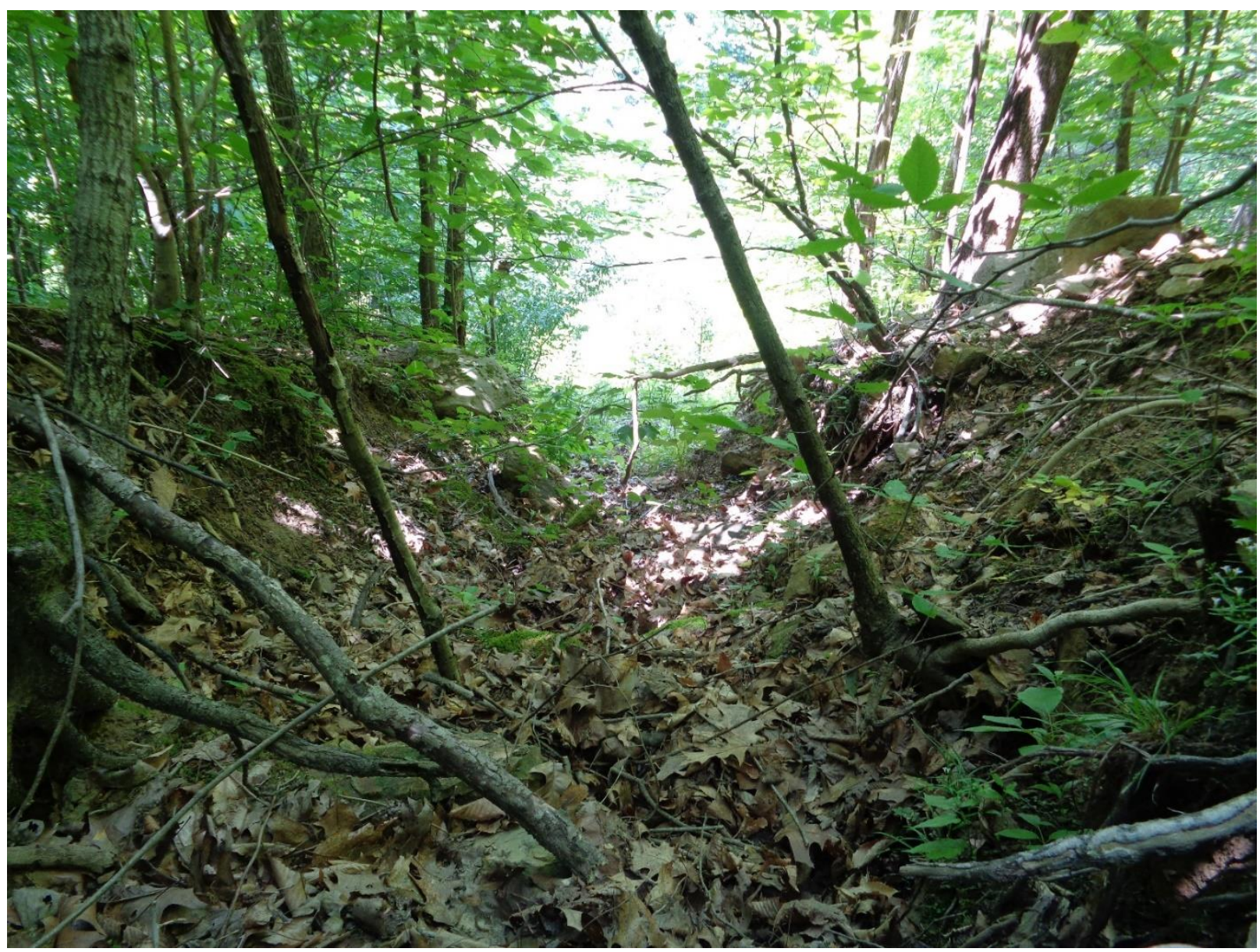

Figure 35. Downslope view of gully in the EIP \#5 catchment. The gully was created by overtopping or failure of a retention cell above the colluvial sideslope of the valley fill. The gully has a maximum width of $\sim 3.2 \mathrm{~m}$ and a maximum depth of $\sim 1.1 \mathrm{~m}$. This section of the gully extends $\sim 30 \mathrm{~m}$ from the retention cell to a section to a possible slope failure. 


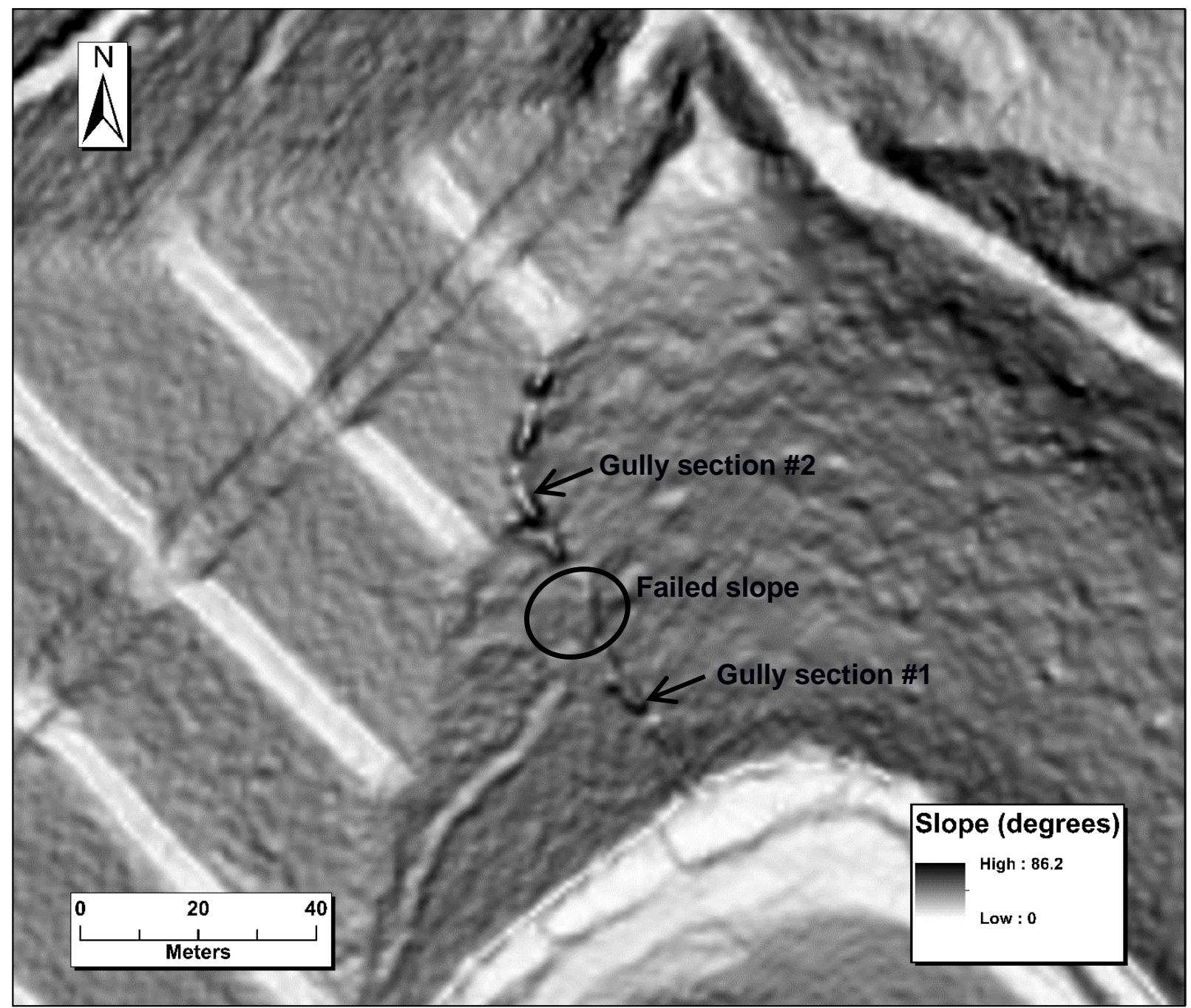

Figure 36. A $1 \mathrm{~m} \mathrm{LiDAR-derived} \mathrm{slopeshade} \mathrm{of} \mathrm{the} \mathrm{gully} \mathrm{in} \mathrm{EIP} \mathrm{\# 5} \mathrm{catchment.} \mathrm{The} 1^{\text {st }}$ section of the gully extends from the sediment cell to the suspected slope failure. The $2^{\text {nd }}$ section of the gully extends $\sim 38 \mathrm{~m}$ beyond the slope from the colluvial sideslope to the interface between the sideslope and the valley fill face. 


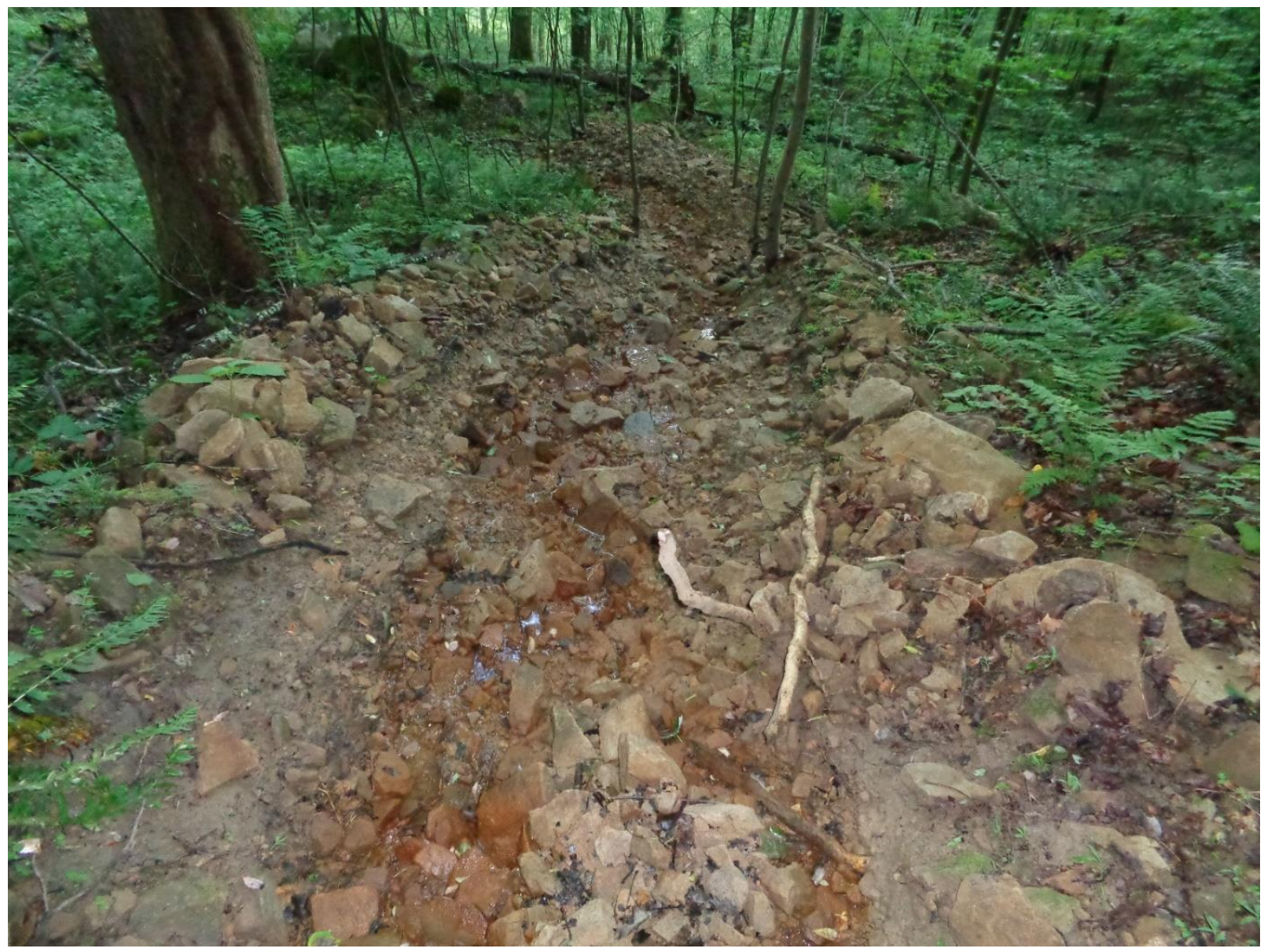

Figure 37. Small debris flow track extending from failed retention cell to a topographic bench below. The $\sim 2 \mathrm{~m}$ wide track is deeply eroded near the sediment cell. Cobble levees line both sides of the deposit, and the deposit ends in a lobate snout. These features are indicative of a debris flow deposit (Major, 1997). 


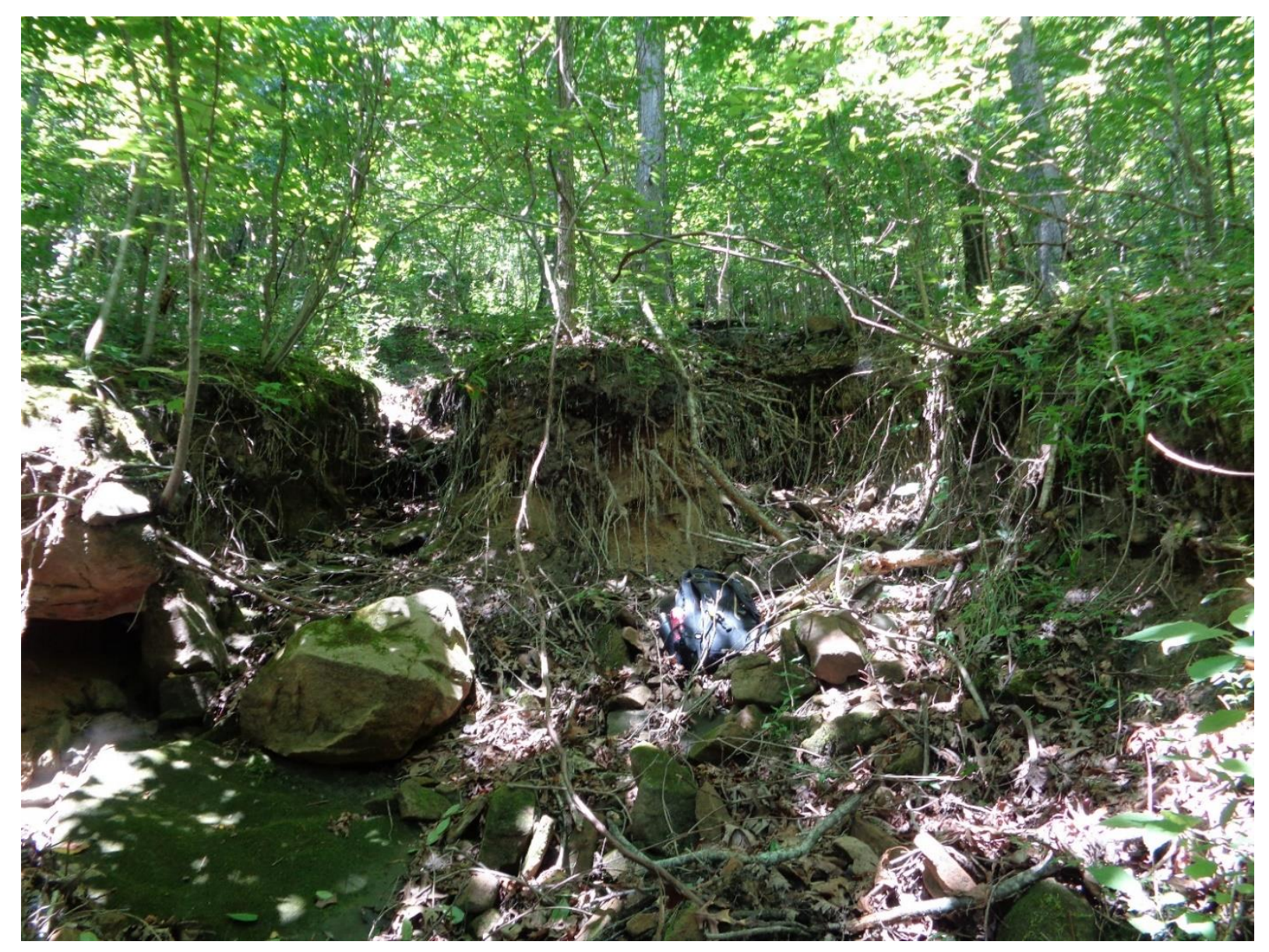

Figure 38. Looking upslope from within a gully in Whitman \#12 catchment initiated by intentional discharge from a series of connected retention cells above. The width of the pictured section is $\sim 5 \mathrm{~m}$ and the depth is $\sim 1.5 \mathrm{~m}$. The gully extends $\sim 74 \mathrm{~m}$ within the colluvial sideslope above the valley fill. 


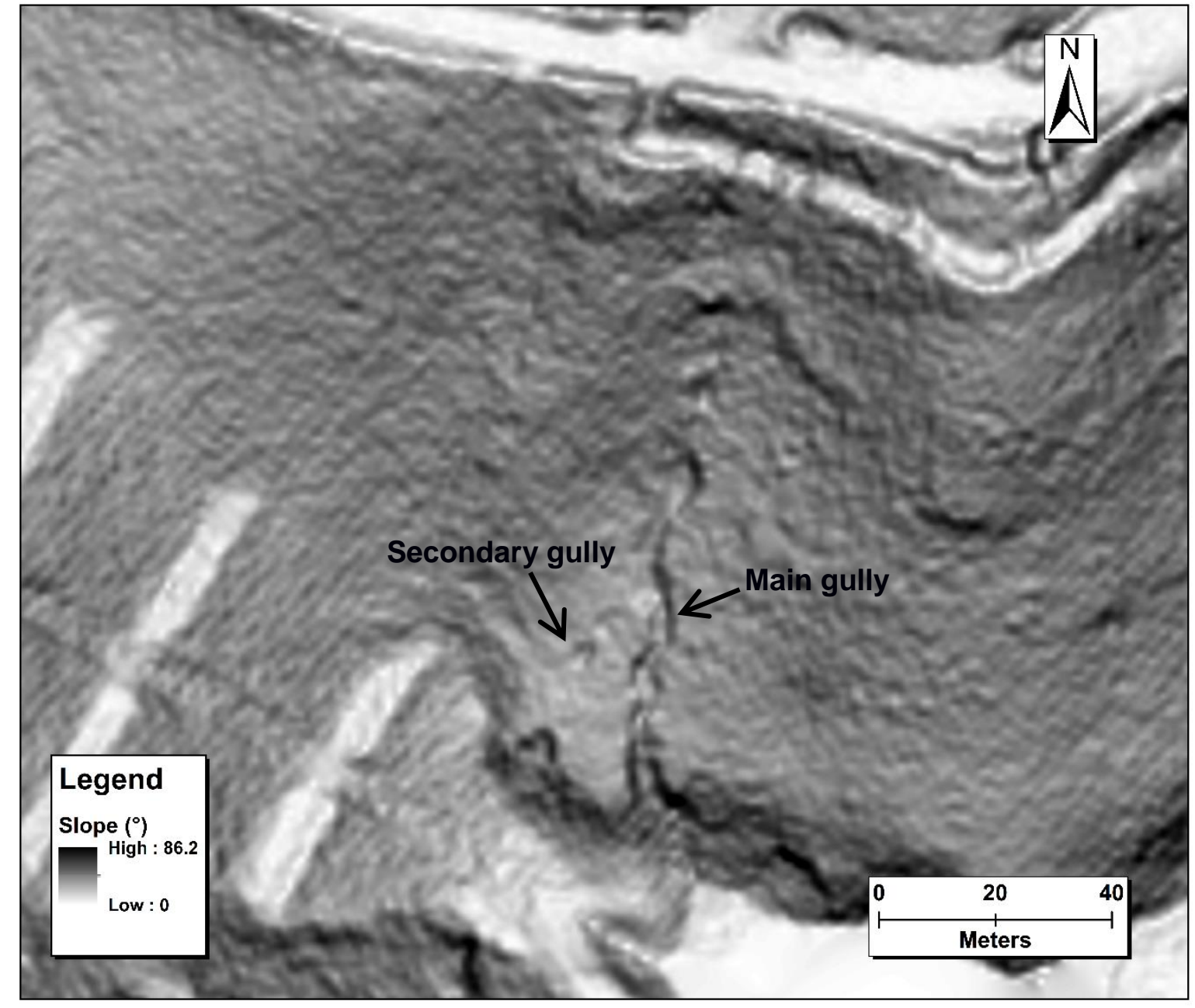

Figure 39. A $1 \mathrm{~m}$ LiDAR-derived slopeshade of a gully in the Whitman \#18 catchment induced by intentional discharge from a series of retention cells. The main gully extends $\sim 74 \mathrm{~m}$. A smaller secondary gully extends from the main gully and terminates in a landslide scar. 


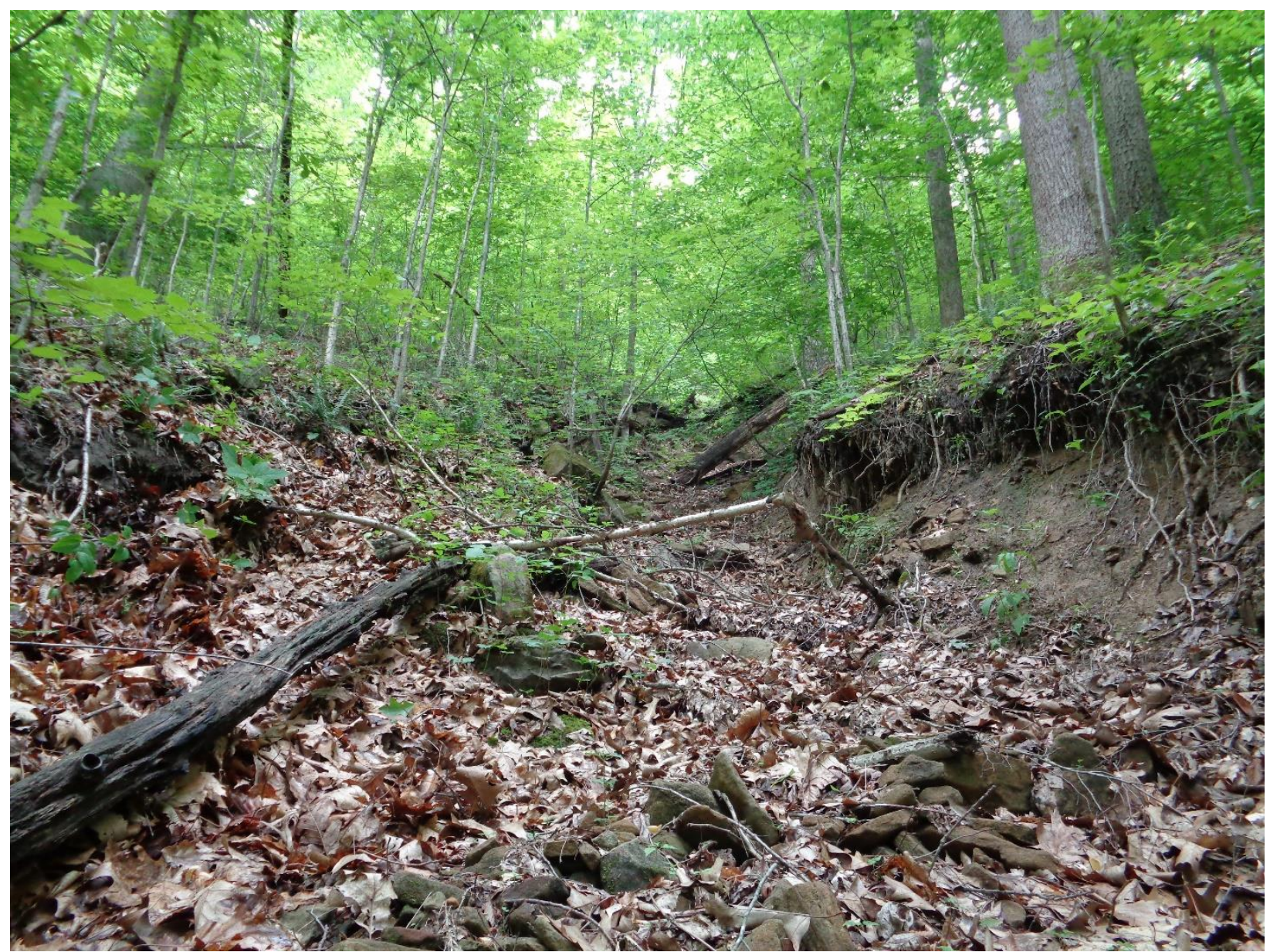

Figure 40. Upslope view from within gully initiated by a pipe discharging water from a retention cell directly onto a sideslope within the Whitman \#16 catchment. The gully is $\sim 4 \mathrm{~m}$ wide and $\sim 1.5 \mathrm{~m}$ deep at this point. The gully extends a total of $\sim 220 \mathrm{~m}$ down to the toe of the Whitman \#18 refuse fill where it erodes the interface between of sideslope and valley fill face for $\sim 115 \mathrm{~m}$. 


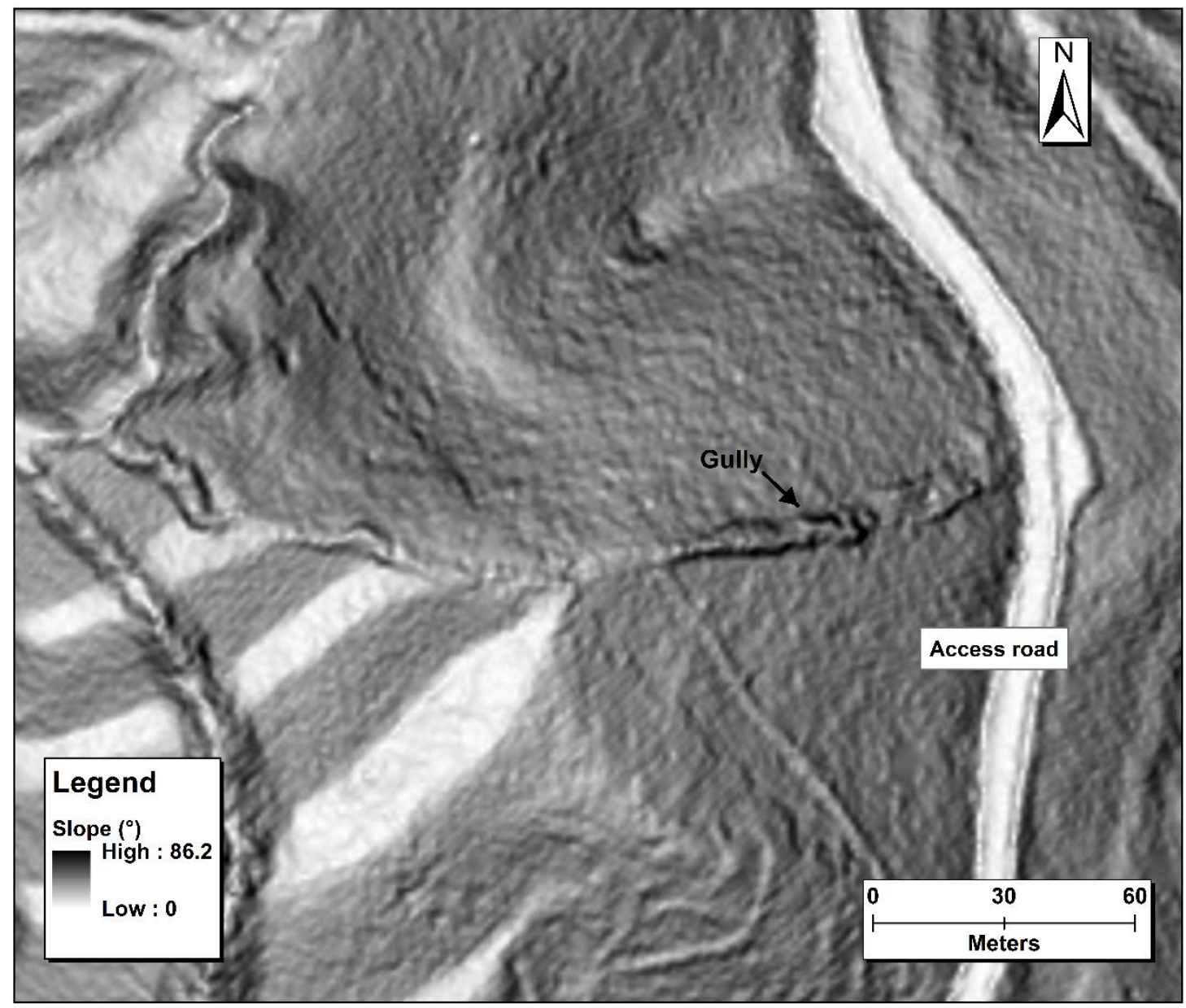

Figure 41. A $1 \mathrm{~m}$ LiDAR-derived slopeshade of a gully within the Whitman \#18 catchment. The gully was initiated by retention cell discharging directly onto a colluvial sideslope via an overflow pipe. The gully extends $\sim 220 \mathrm{~m}$ from the access road to the toe of the valley fill. 


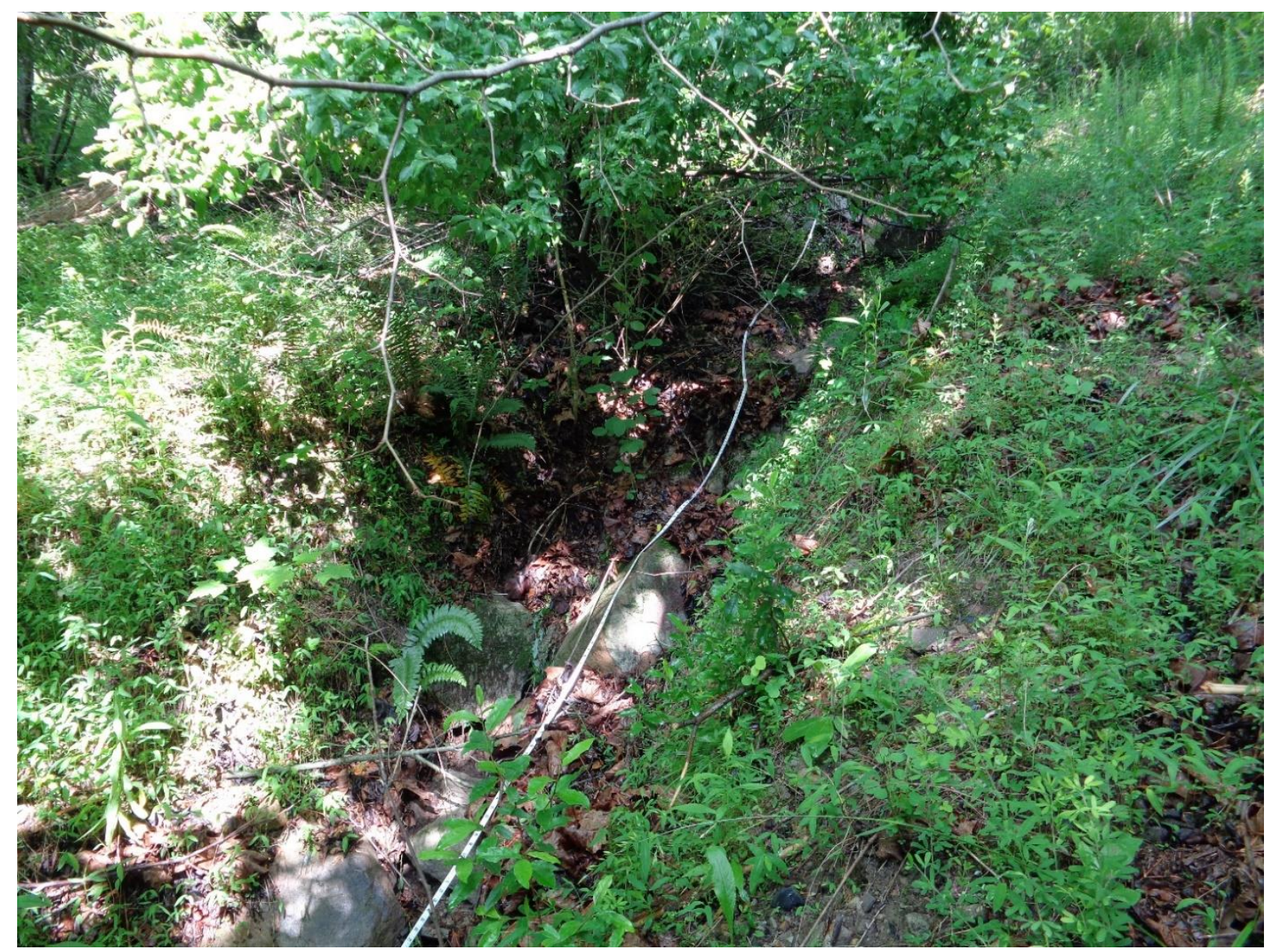

Figure 42. Looking upslope at the lower section of a $\sim 27 \mathrm{~m}$ long gully. The gully extends from terrace to terrace on the valley fill face of Whitman \#8. A small wetland area on the upper terrace provides runoff to the upper part of gully. 


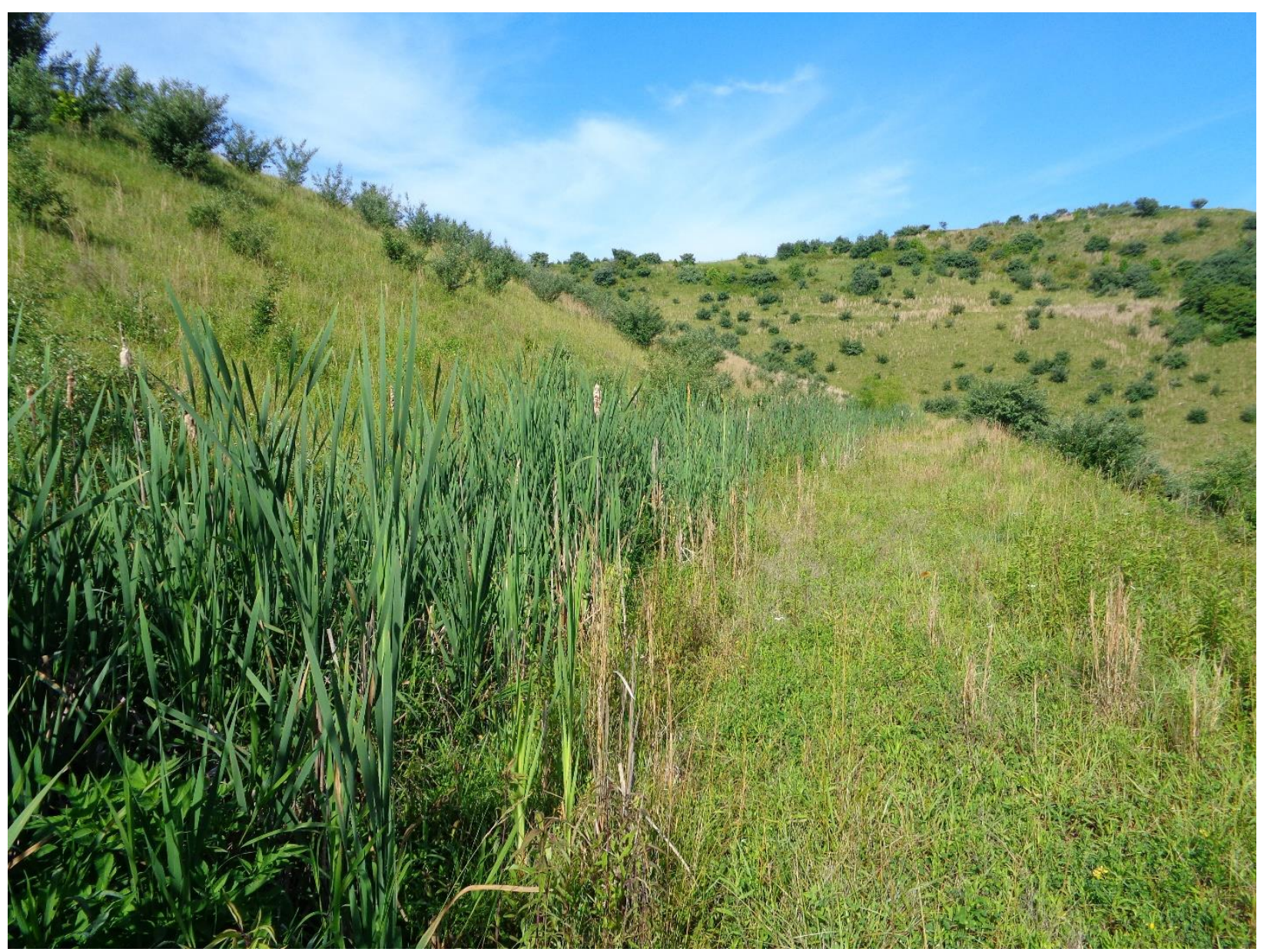

Figure 43. An example of a small wetland forming along the terraces of valley fill faces of EIP \#3. Terraces are designed to funnel any surface runoff to constructed drains. A gentle gradient in terrace flat prevents flow off the edge of terrace onto the slope below. The pictured terrace is $\sim 5 \mathrm{~m}$ wide. 


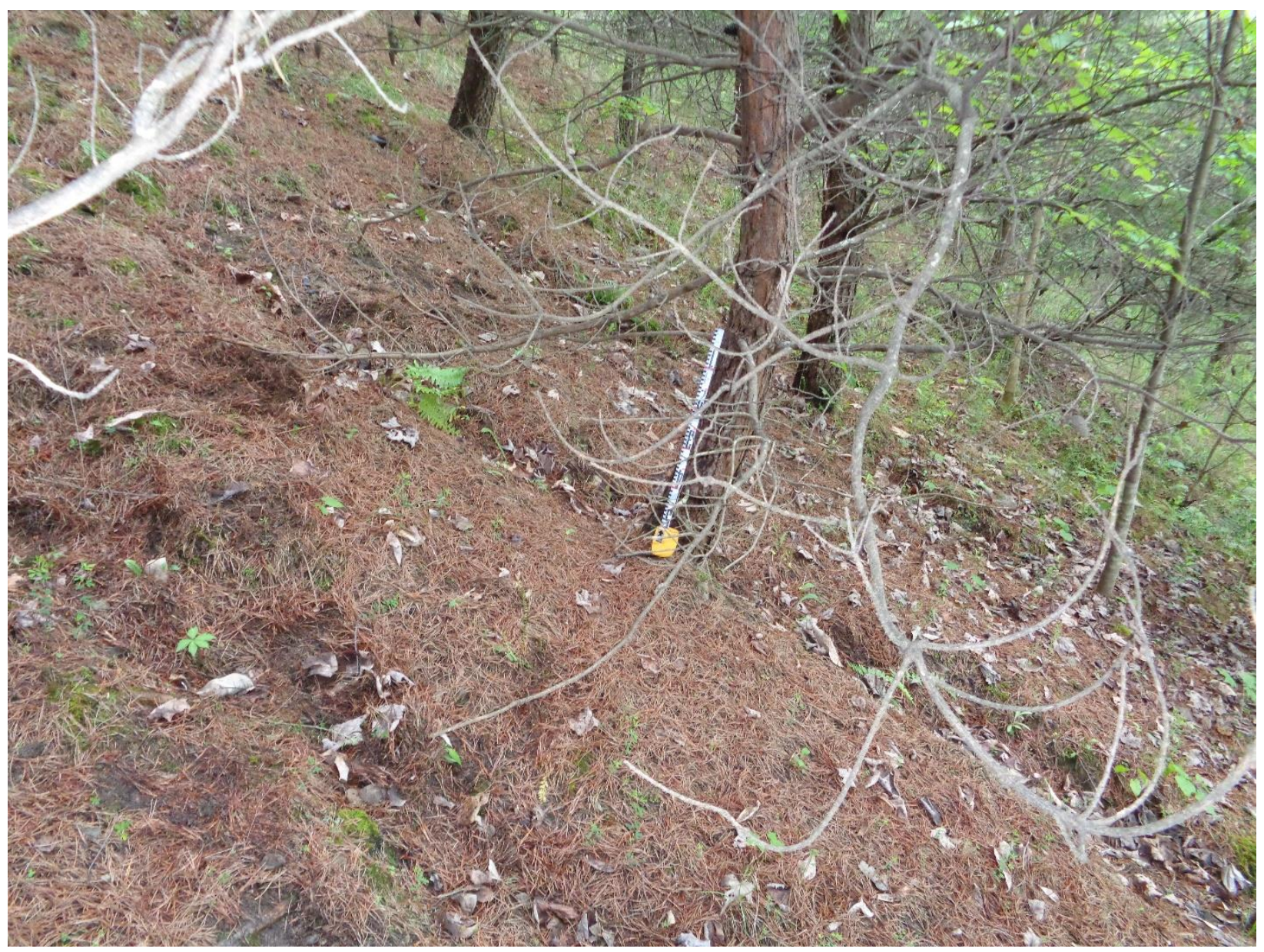

Figure 44. Three small gullies on a slope between two terraces within a planted pine grove in the Whitman \#8 catchment. The gullies are covered in duff and do not appear to be actively eroding. There were 11 closely spaced gullies in this location. The tape measure is extended to $0.5 \mathrm{~m}$. 


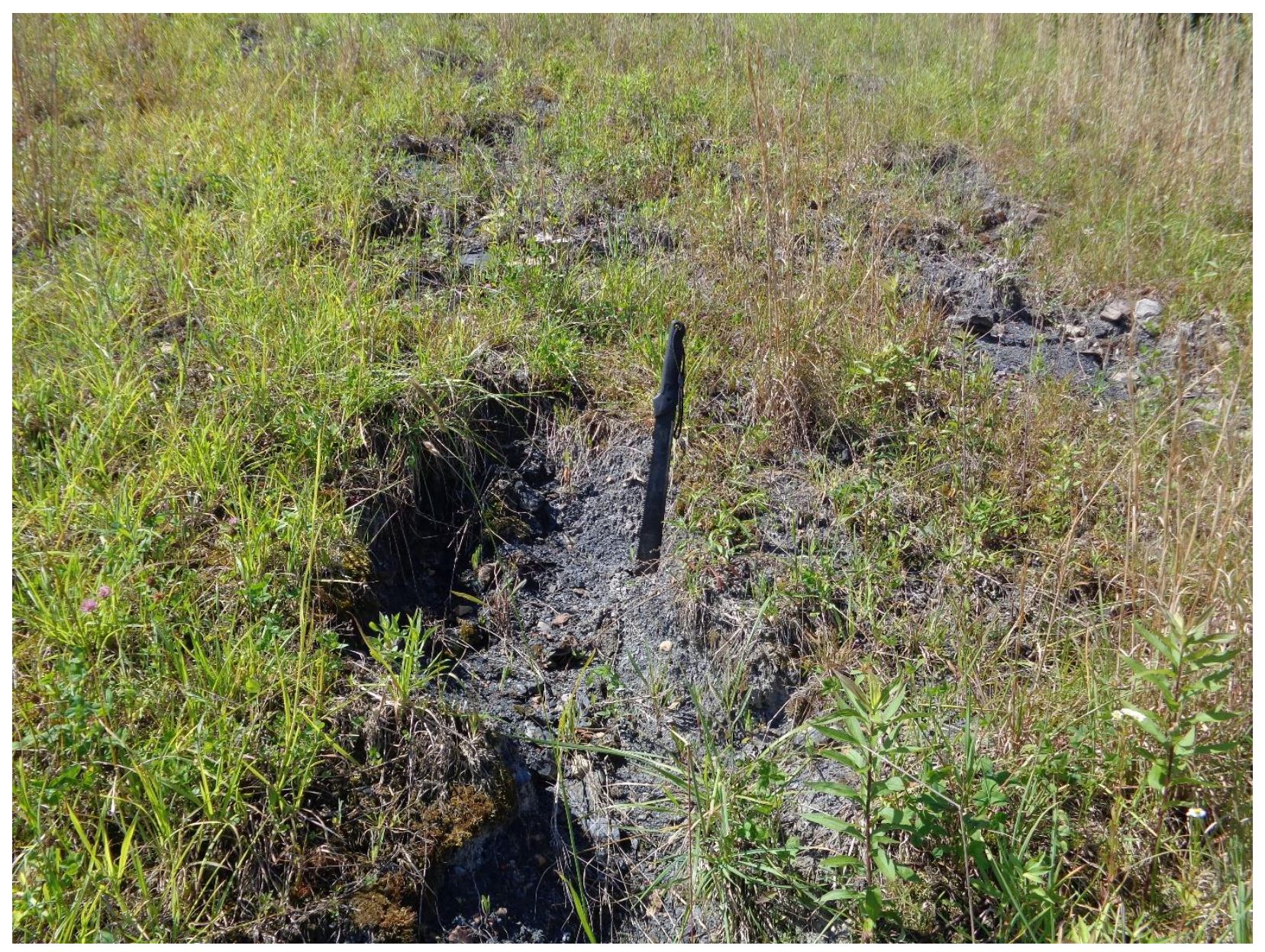

Figure 45. Gully eroded into finer, shaley sediments present on a slope between two terraces on the valley fill face of EIP \#3. The machete is $64 \mathrm{~cm}$ long. 


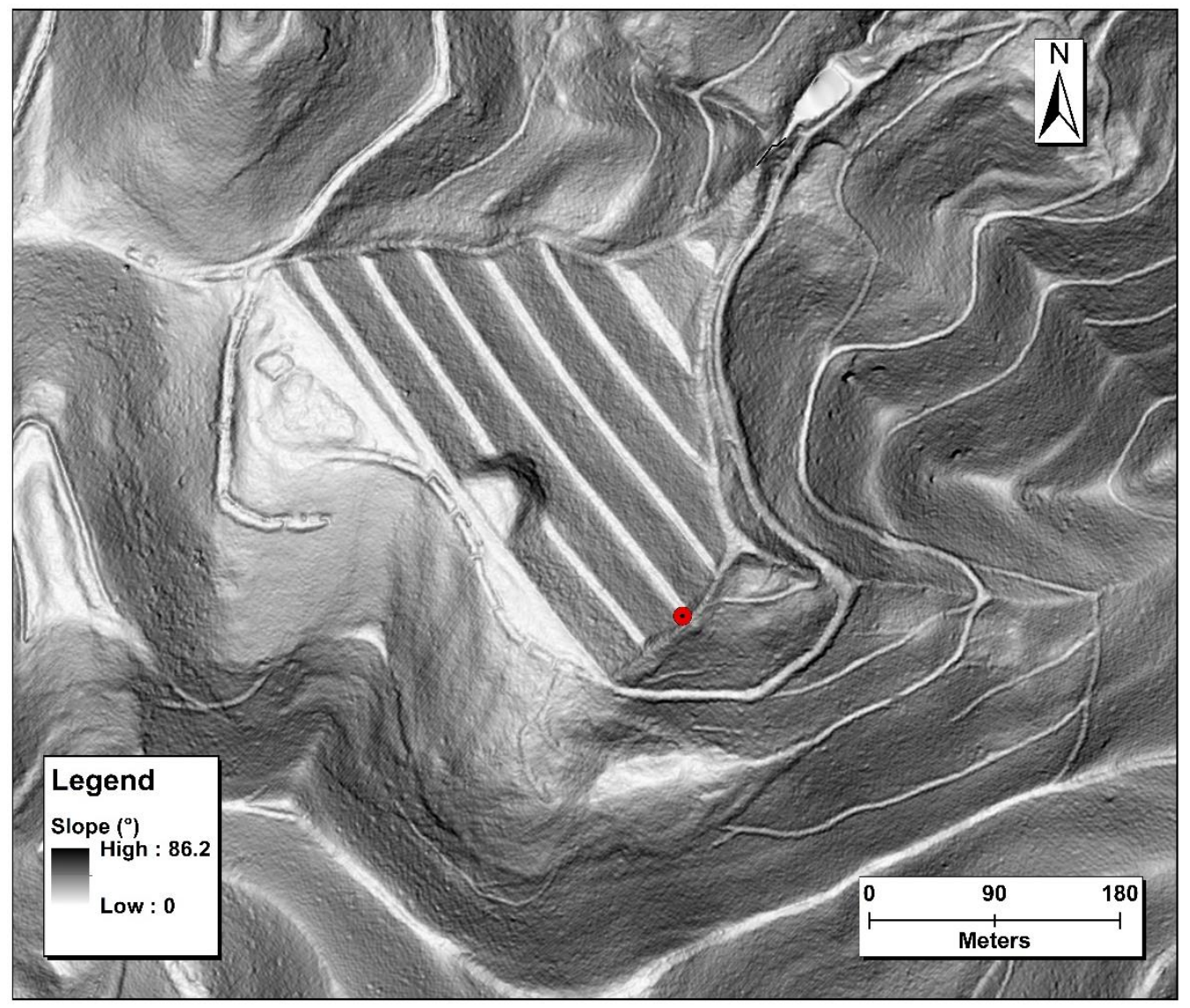

Figure 46. A $1 \mathrm{~m}$ LiDAR-derived slopeshade of the Whitman \#18 catchment with a red point indicating the location of a gully. The $4.5 \mathrm{~m}$ long gully eroded into the edge of the terrace into the constructed groin drain. This is the designed flowpath of runoff from the terrace. 


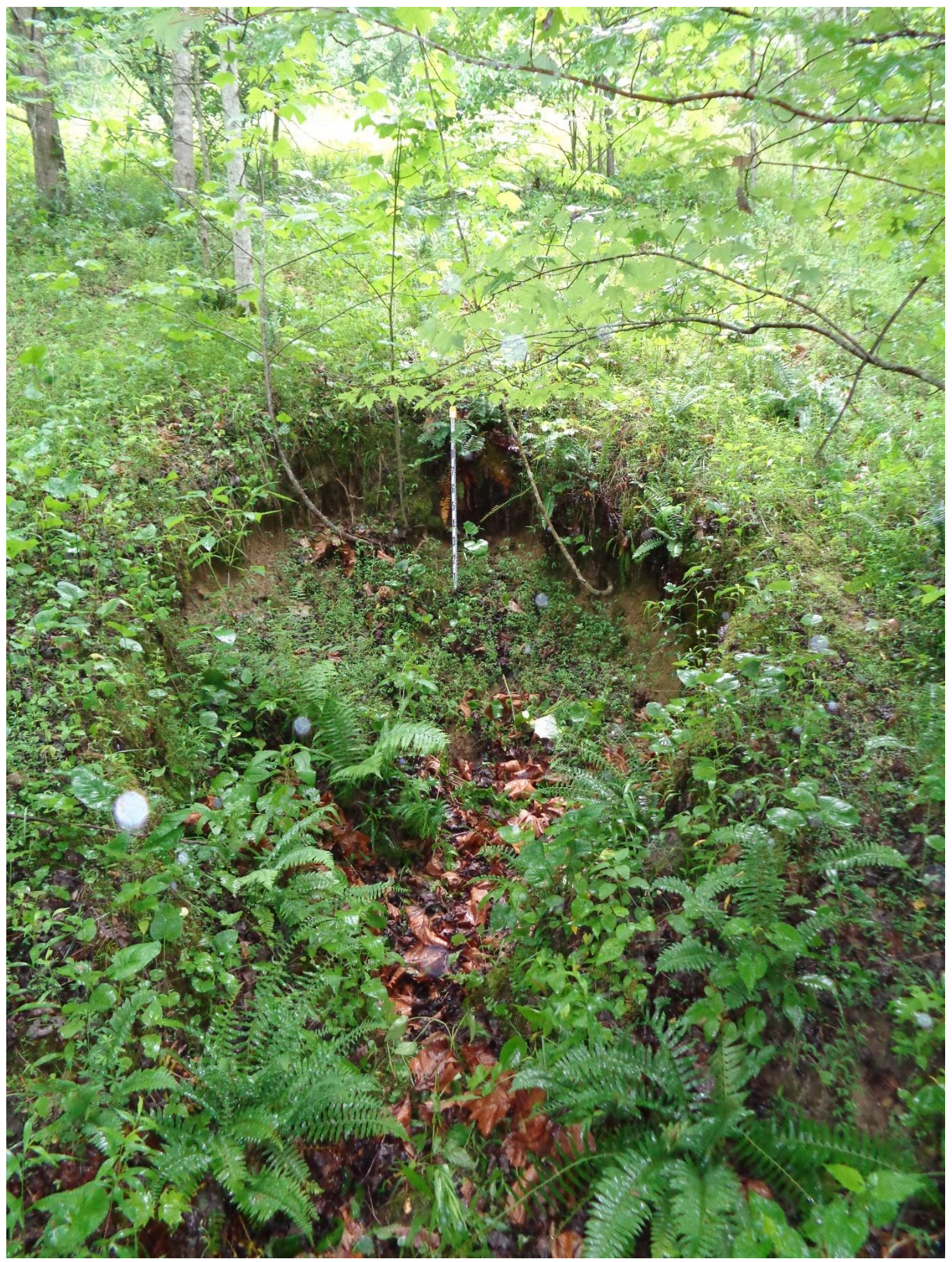

Figure 47. Looking upslope at a seepage-induced erosion feature, occurring on the face of in the Whitman \#8 valley fill. The feature has a maximum width of $2.6 \mathrm{~m}$ and a maximum depth of $1.1 \mathrm{~m}$ (measured along a central transect that mimicked the former slope). The measuring tape is extended to $1 \mathrm{~m}$. 


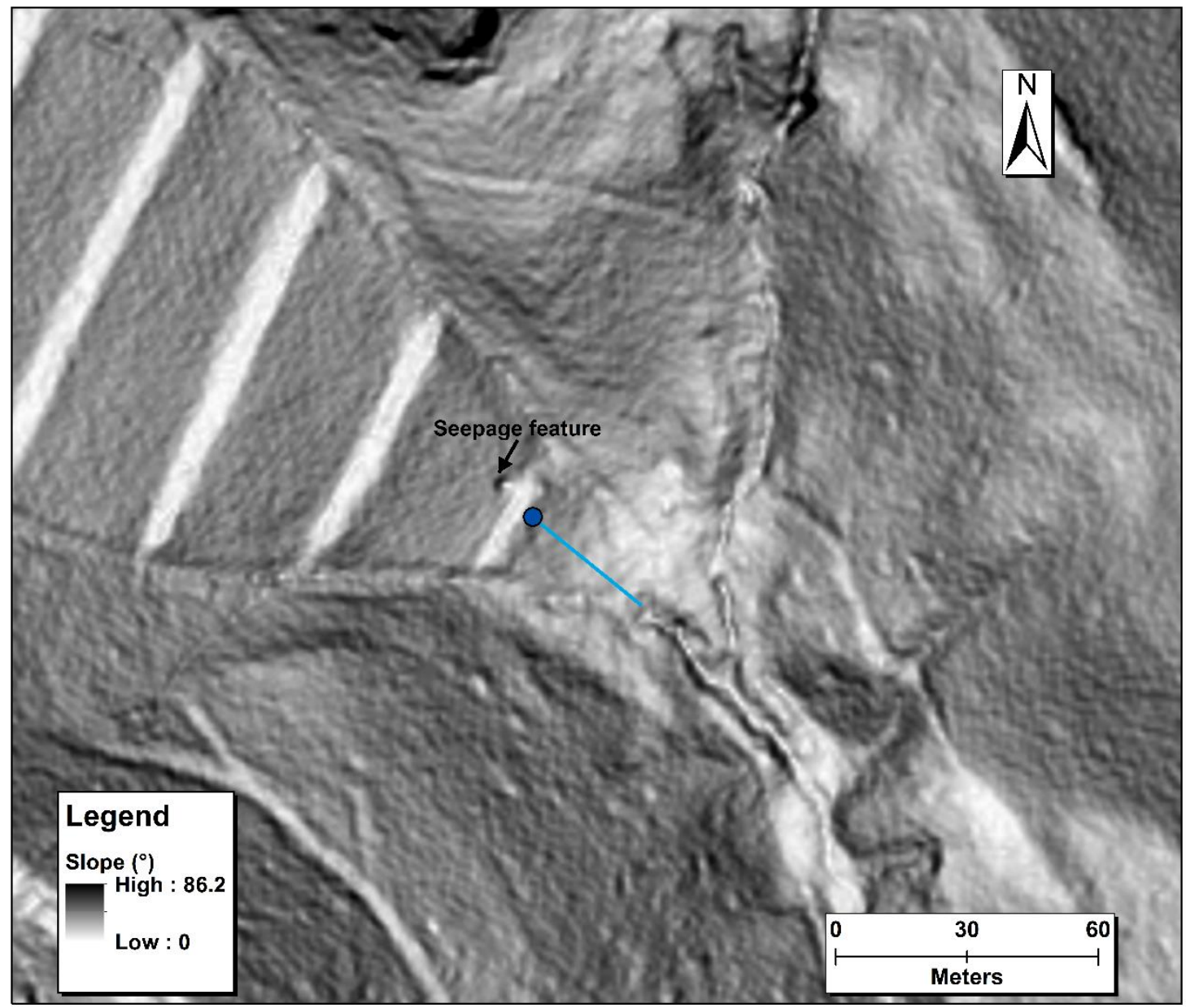

Figure 48. A $1 \mathrm{~m}$ LiDAR-derived slopeshade of the Whitman \#8 catchment showing the location of the seepage-induced erosion feature in Fig. 48. The blue dot and line are the approximate positions of the spring and channel occurring on the toe of the valley outside of the constructed groin drains. The channel extends $\sim 32 \mathrm{~m}$ along the center of the valley fill toe. 


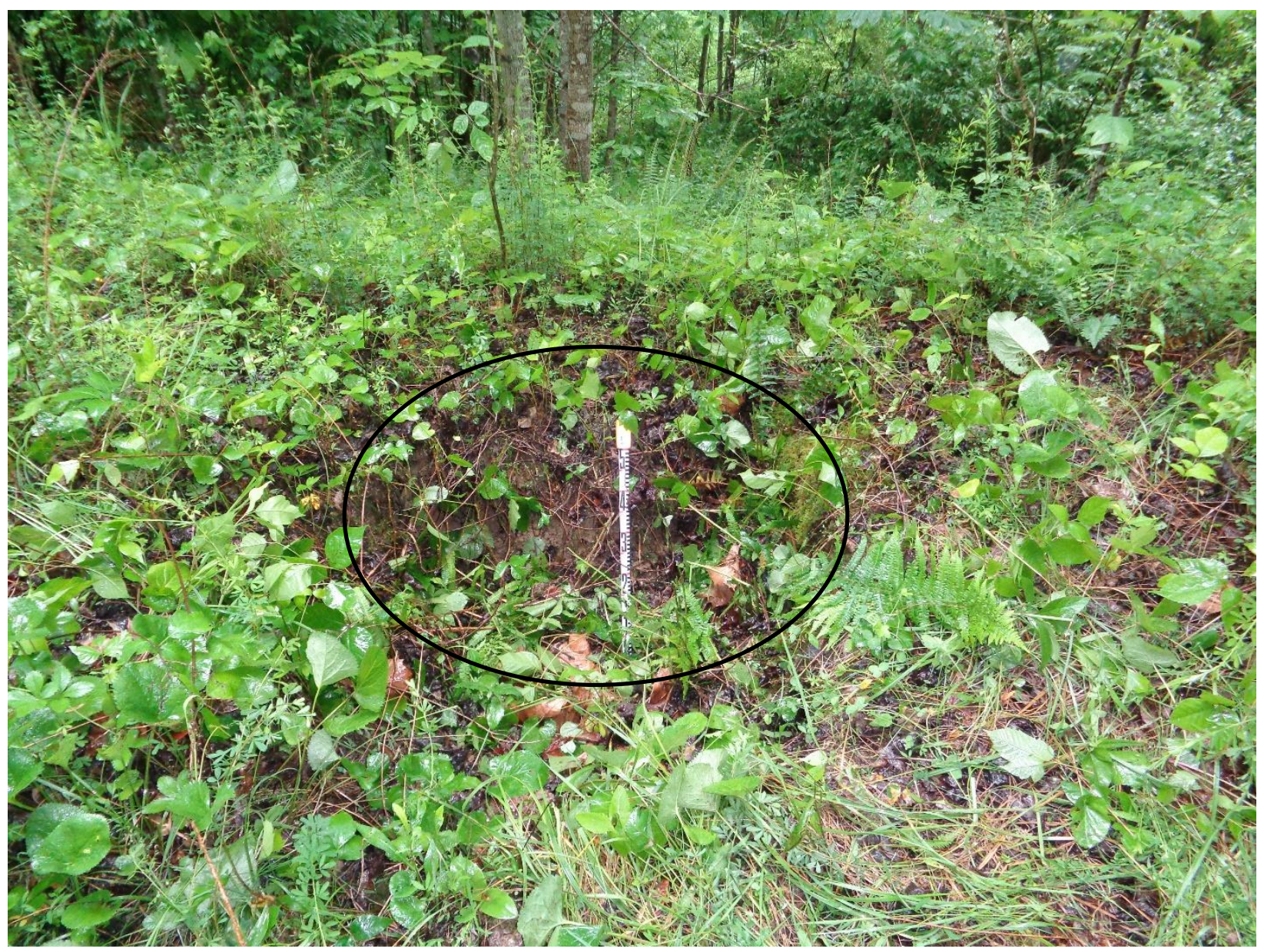

Figure 49. A 1 m diameter depression thought to be induced by subsurface erosion associated with a spring-fed stream. The depression is located on the terrace above the valley fill toe where the stream is located (the last constructed slope before the end of the valley fill). The black line shows the approximate extent of the depression. 


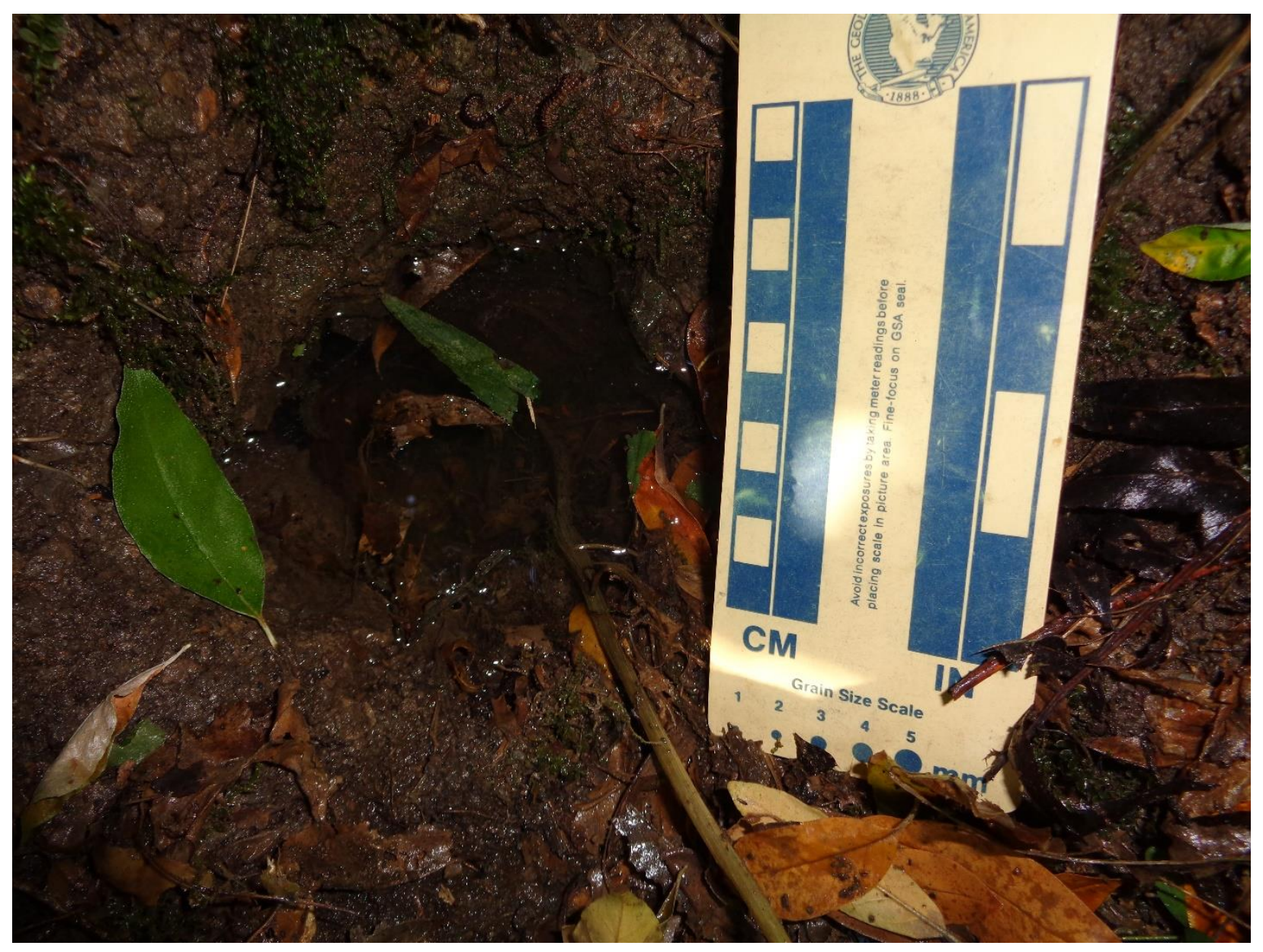

Figure 50. Seep discharging water on the face of EIP \#4 valley fill. Three seeps were spaced closely in this location. The field photo guide is $10 \mathrm{~cm}$ in height. 


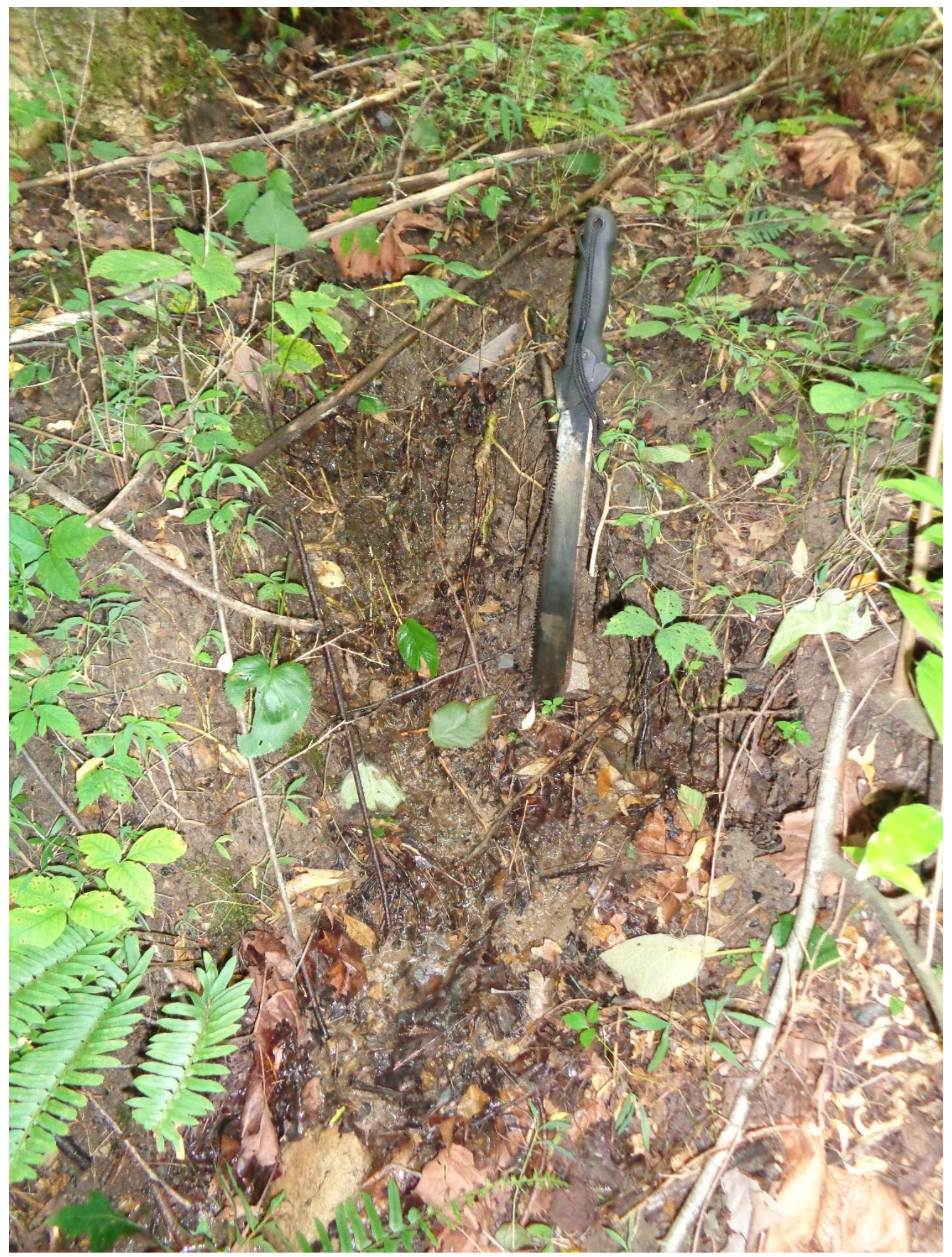

Figure 51. Small gully caused by subsurface erosion on the face of the Whitman \#15 valley fill. The gully measures $\sim 0.5 \mathrm{~m}$ wide and $\sim 0.5$ deep at the head scarp. Notice the water flowing at the bottom of the gully. No overland flowpath was observed above the head scarp. The machete is $64 \mathrm{~cm}$ long. 


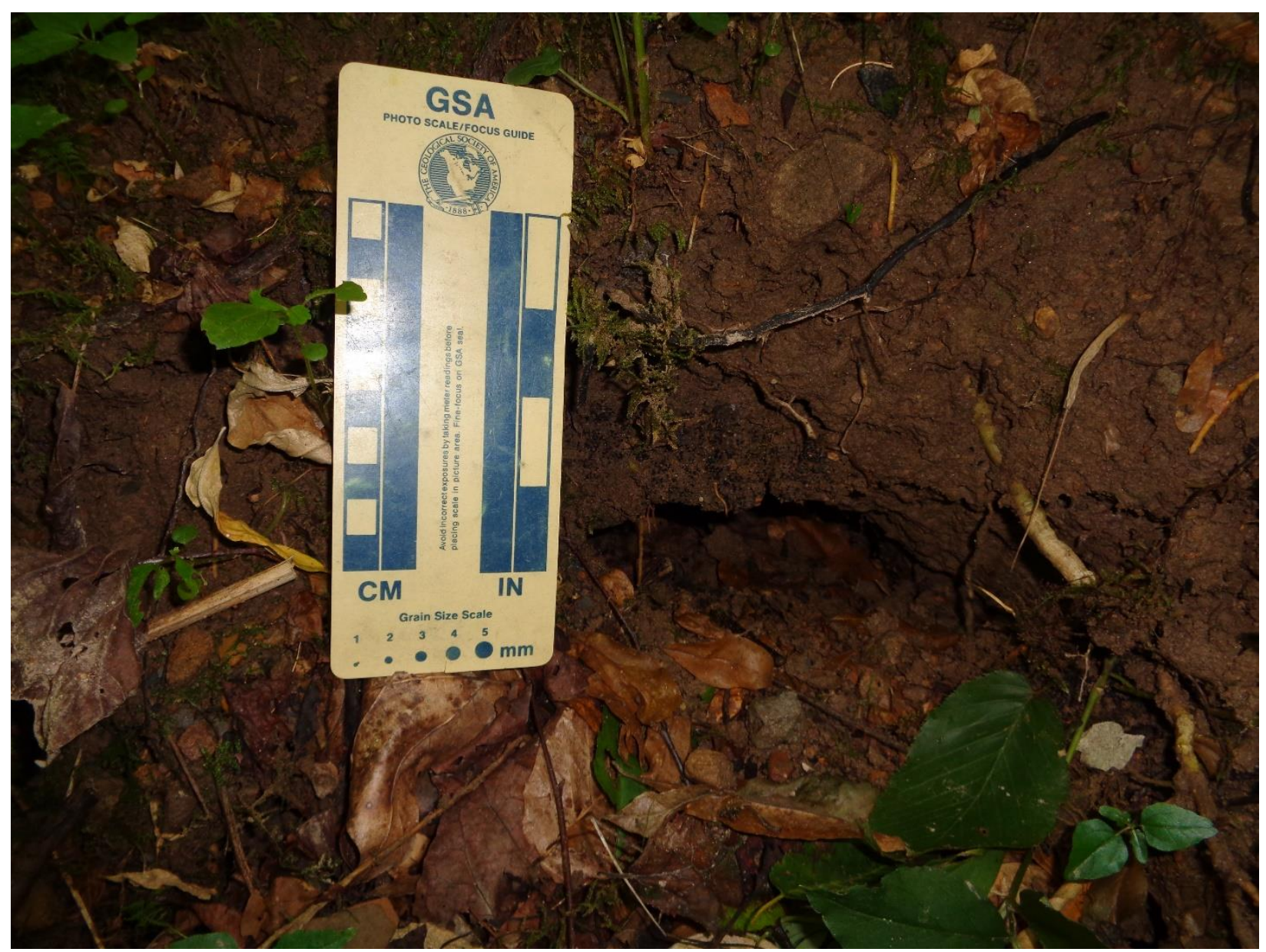

Figure 52. Macropore in mine soil on the face of the Whitman \#15 catchment. The field photo guide is 10 $\mathrm{cm}$. 


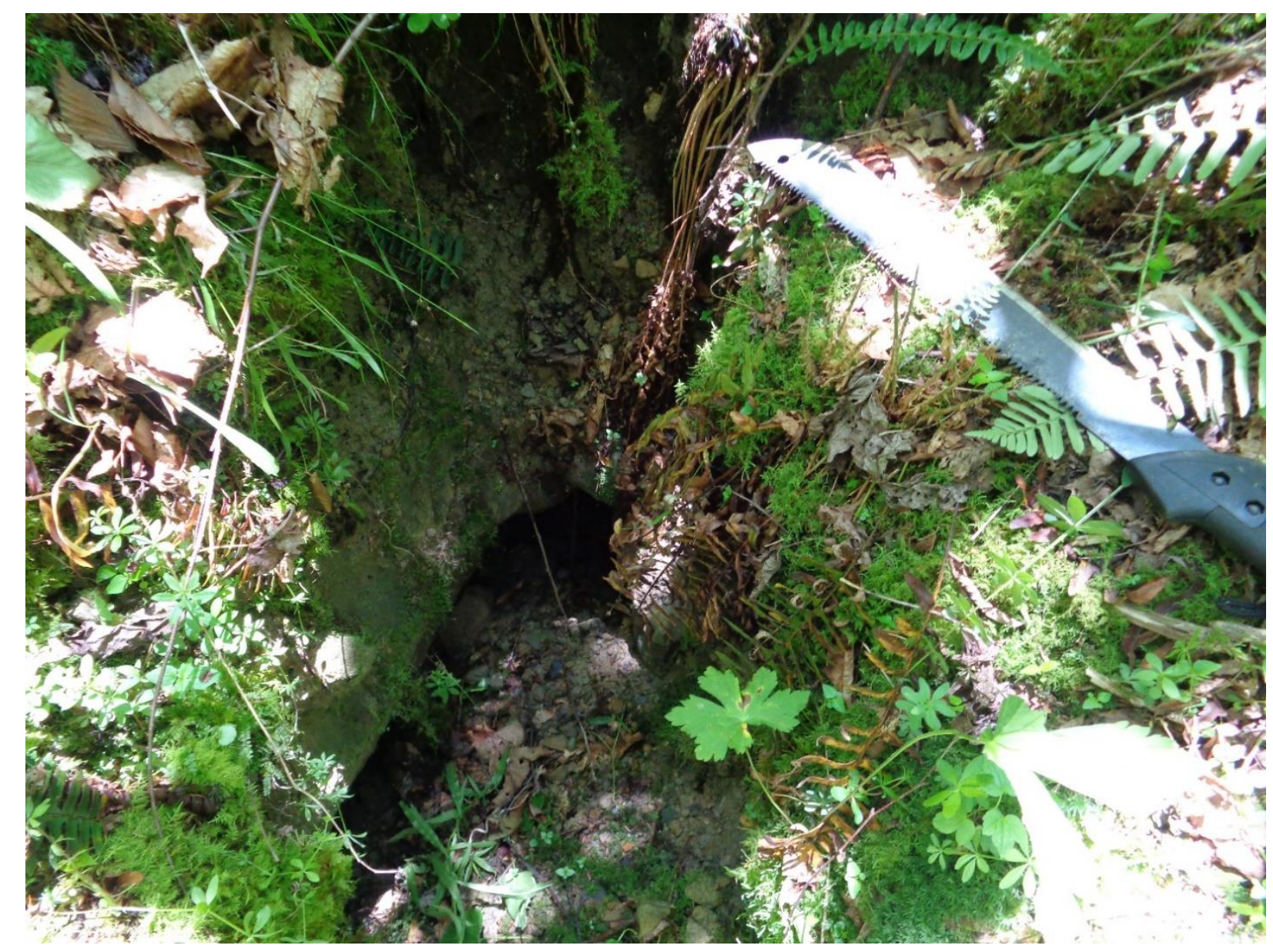

Figure 53. Hole in soil-mantled toe of the Whitman \#7 valley fill. The toe is composed of both soil and boulders. The hole is close to the point where the outlet stream was located and is interpreted to be caused by subsurface winnowing of finer sediments, inducing subsidence. The machete is $64 \mathrm{~cm}$ long. 


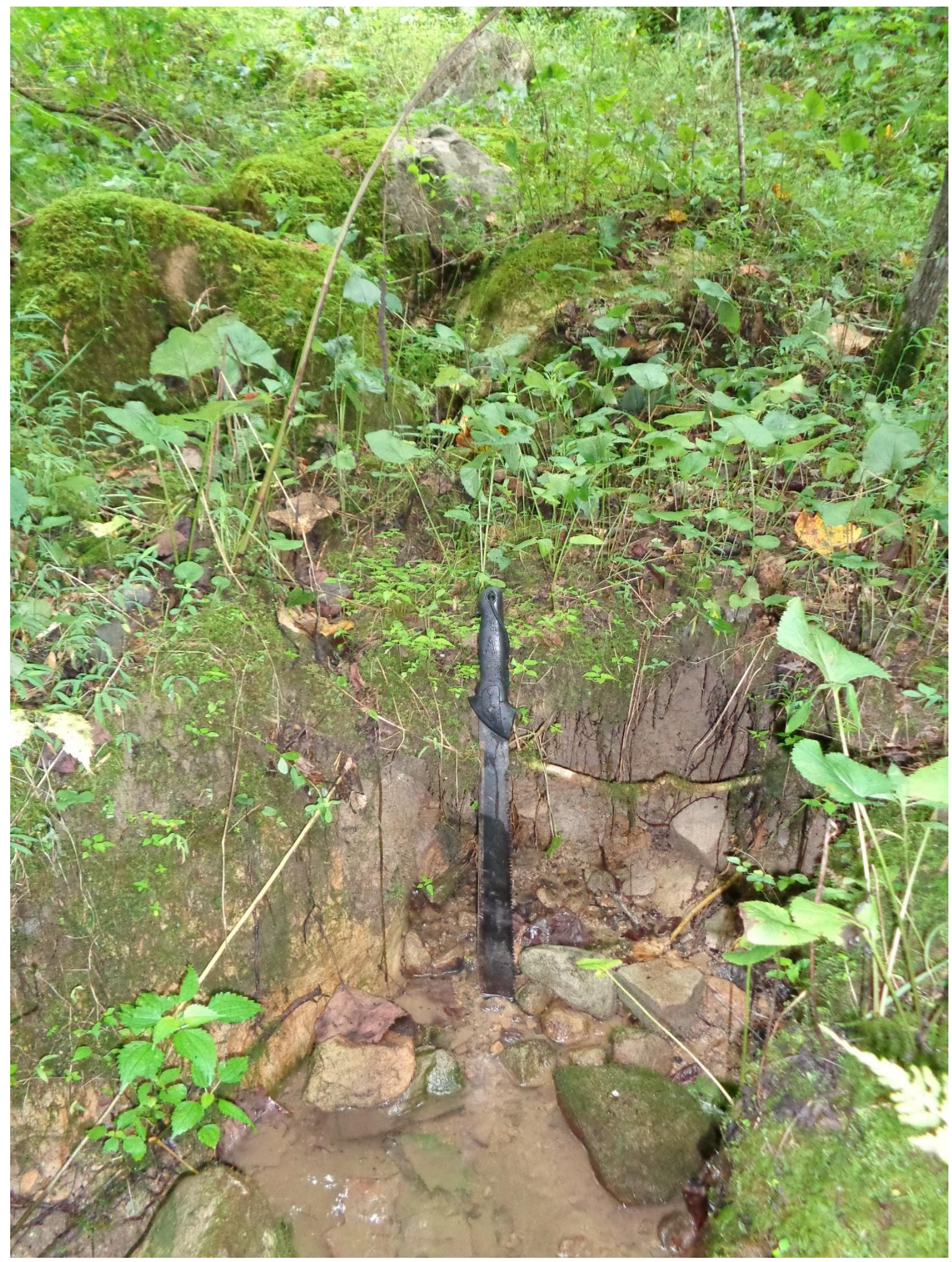

Figure 54. Erosion of finer sediments along the banks of fluvial channel on the toe of the Whitman \#11 valley fill. The machete is $64 \mathrm{~cm}$ long. 


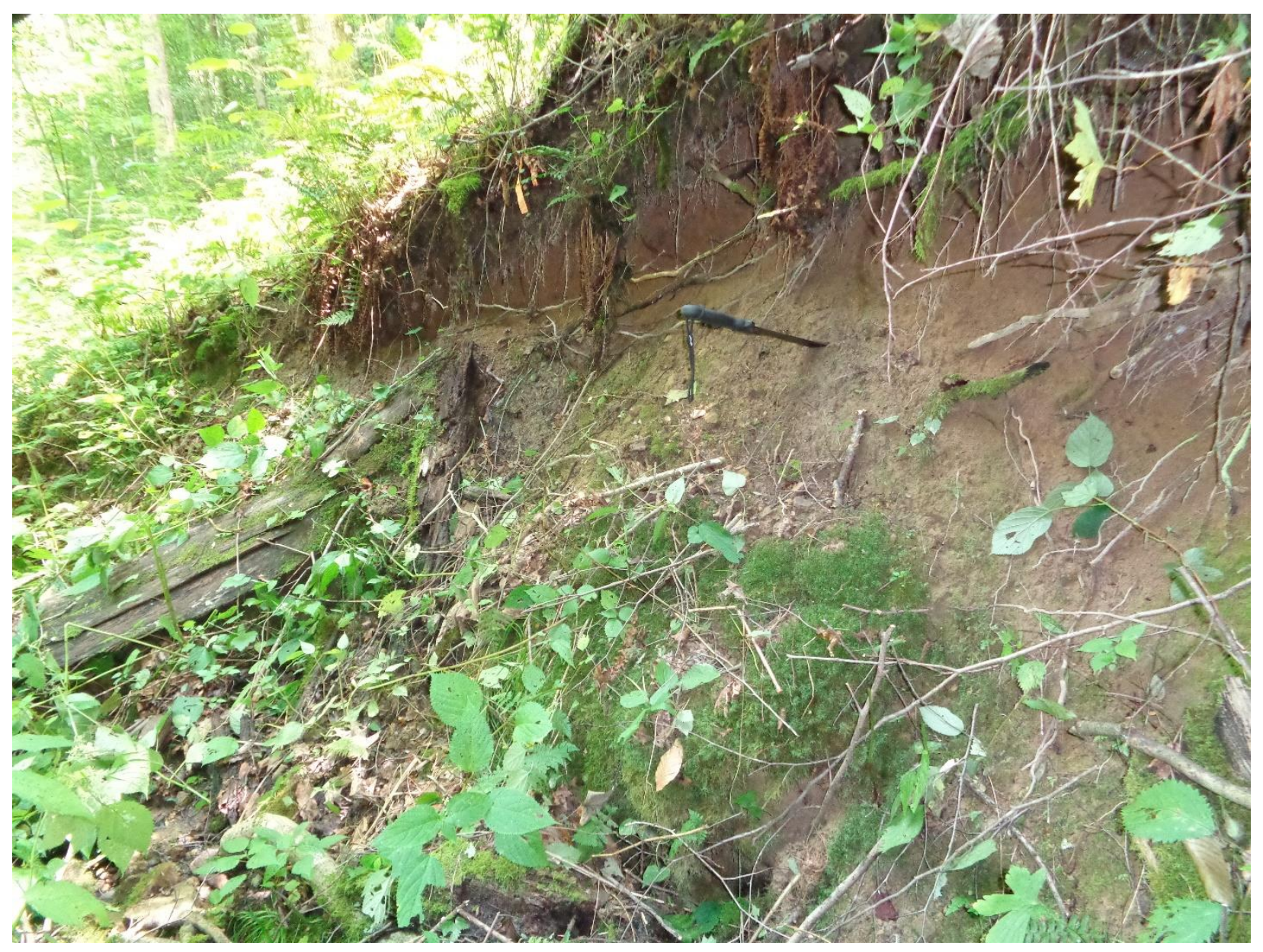

Figure 55. Erosion of colluvial slope near toe of Whitman \#14 valley fill by the outlet stream. The picture is looking downstream. The machete is $64 \mathrm{~cm}$ long. 


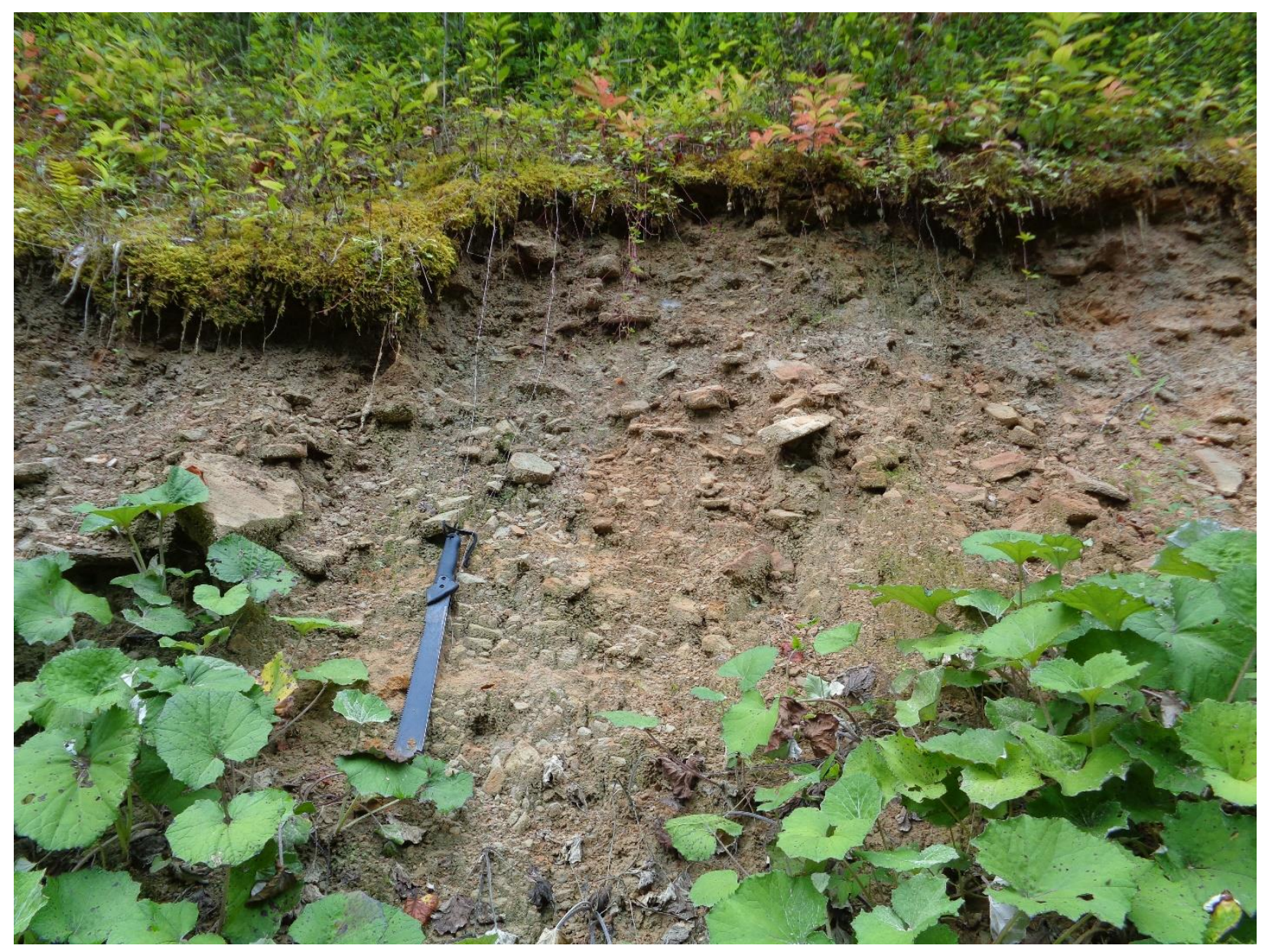

Figure 56. Scarp of landslide located in the former sediment pond area beyond the valley fill toe of Whitman \#13. The scarp was $\sim 12 \mathrm{~m}$ across and occurred $\sim 4 \mathrm{~m}$ up from the base of the slope. The machete is $64 \mathrm{~cm}$ long. 


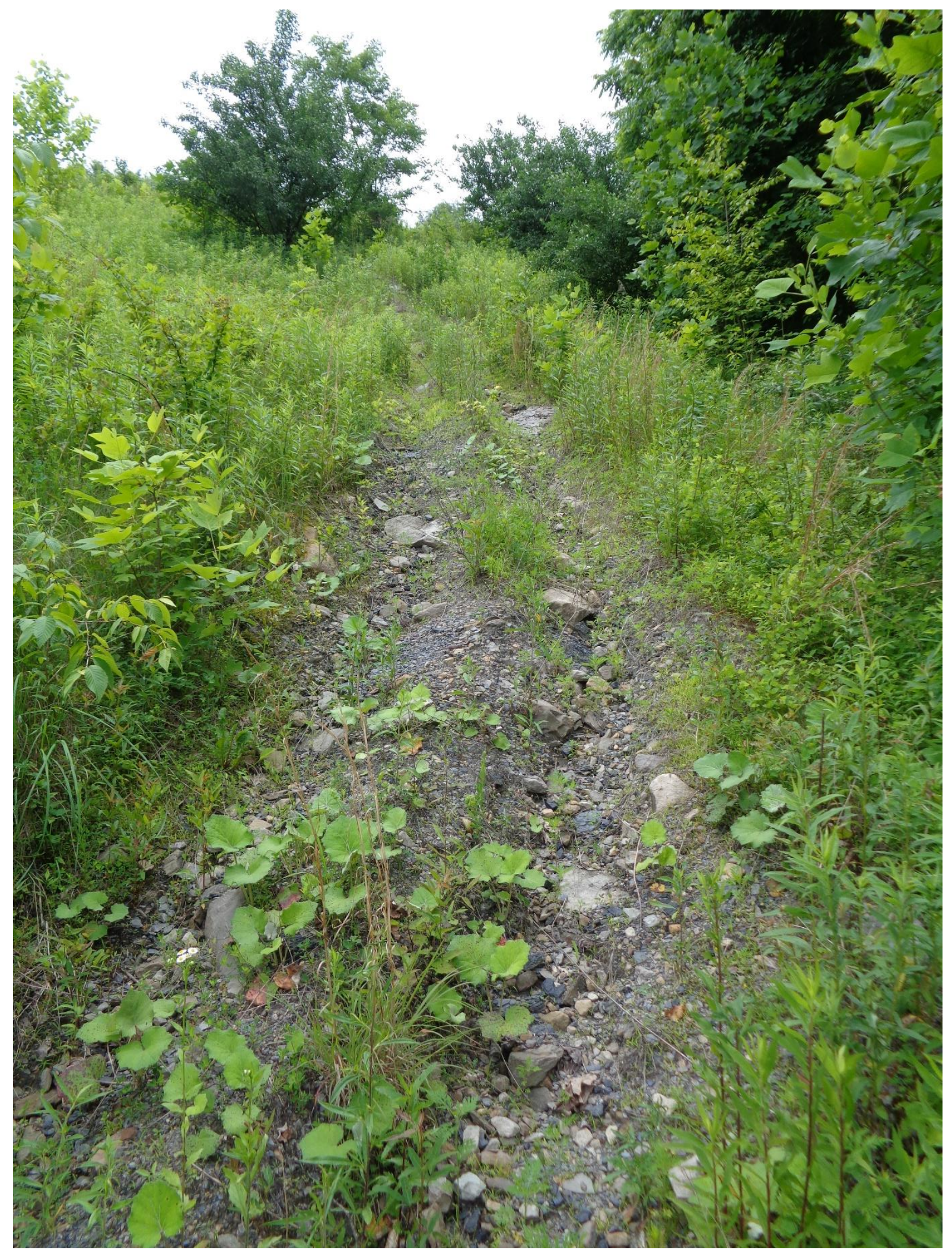

Figure 57. Looking upslope at erosion on the face of EIP \#1 valley fill caused by all-terrain vehicles. The track is $\sim 1.5 \mathrm{~m}$ in width. 


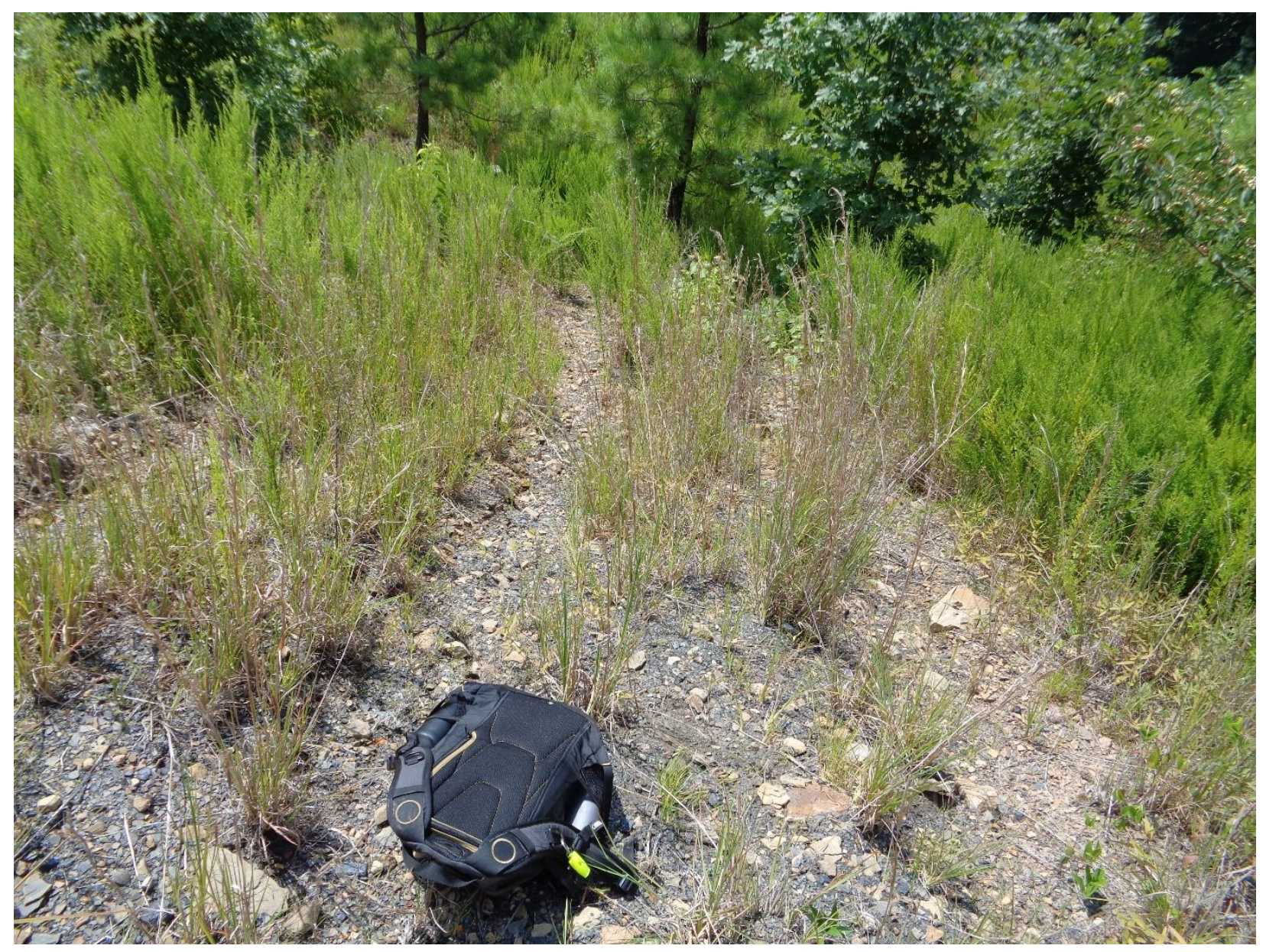

Figure 58. Looking downslope at a patch of bare ground on the face of the Whitman \#21 valley fill. The bare ground is associated with rapidly weathering shale at the surface. The backpack is $\sim 50 \mathrm{~cm}$ wide. 


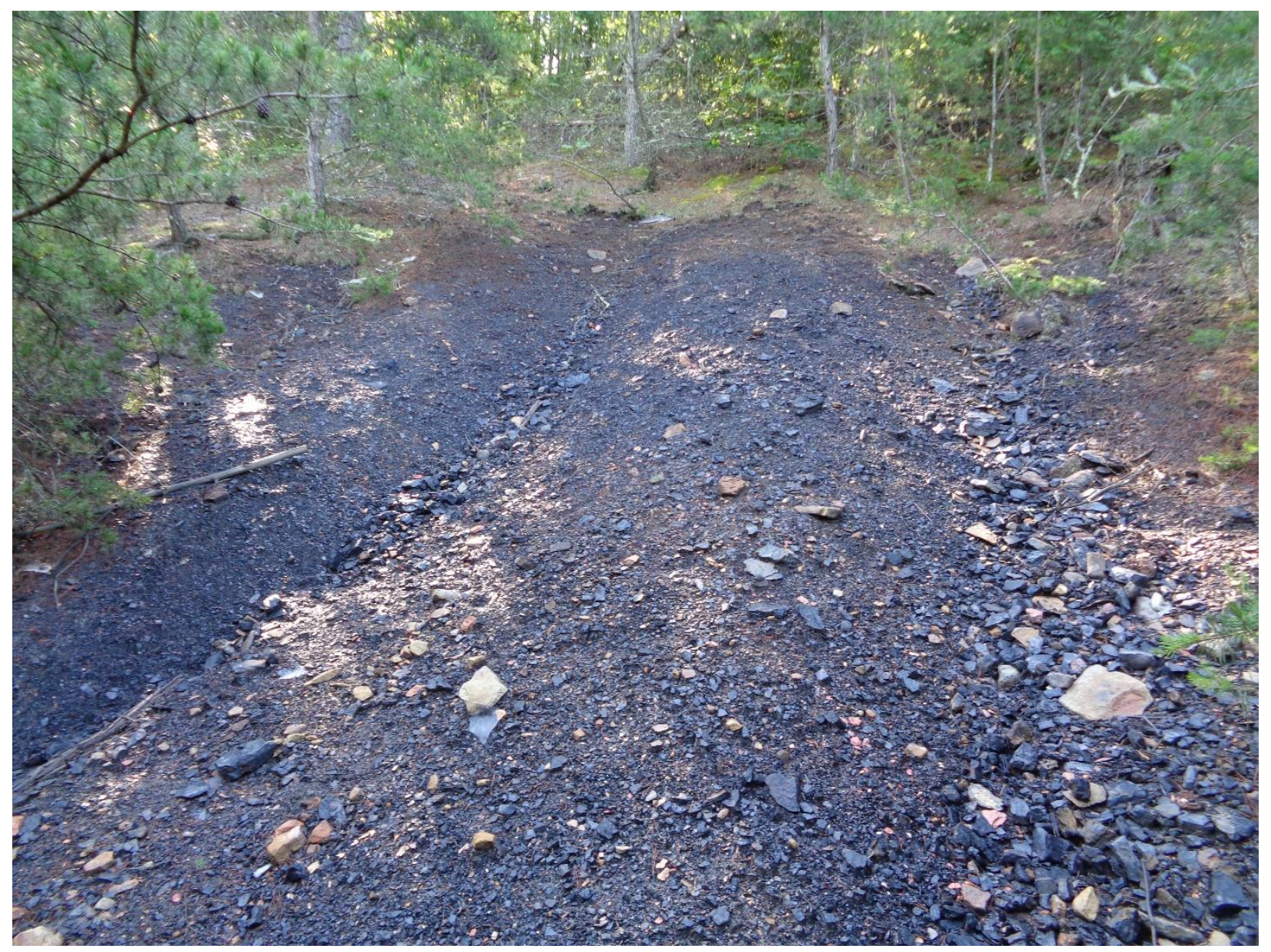

Figure 59. Valley fill face of Whitman \#9, a refuse fill, looking upslope at the finer sediments at the surface. The sediments appear black due to the presence of coal. The bare land surface also shows signs of rill erosion. 


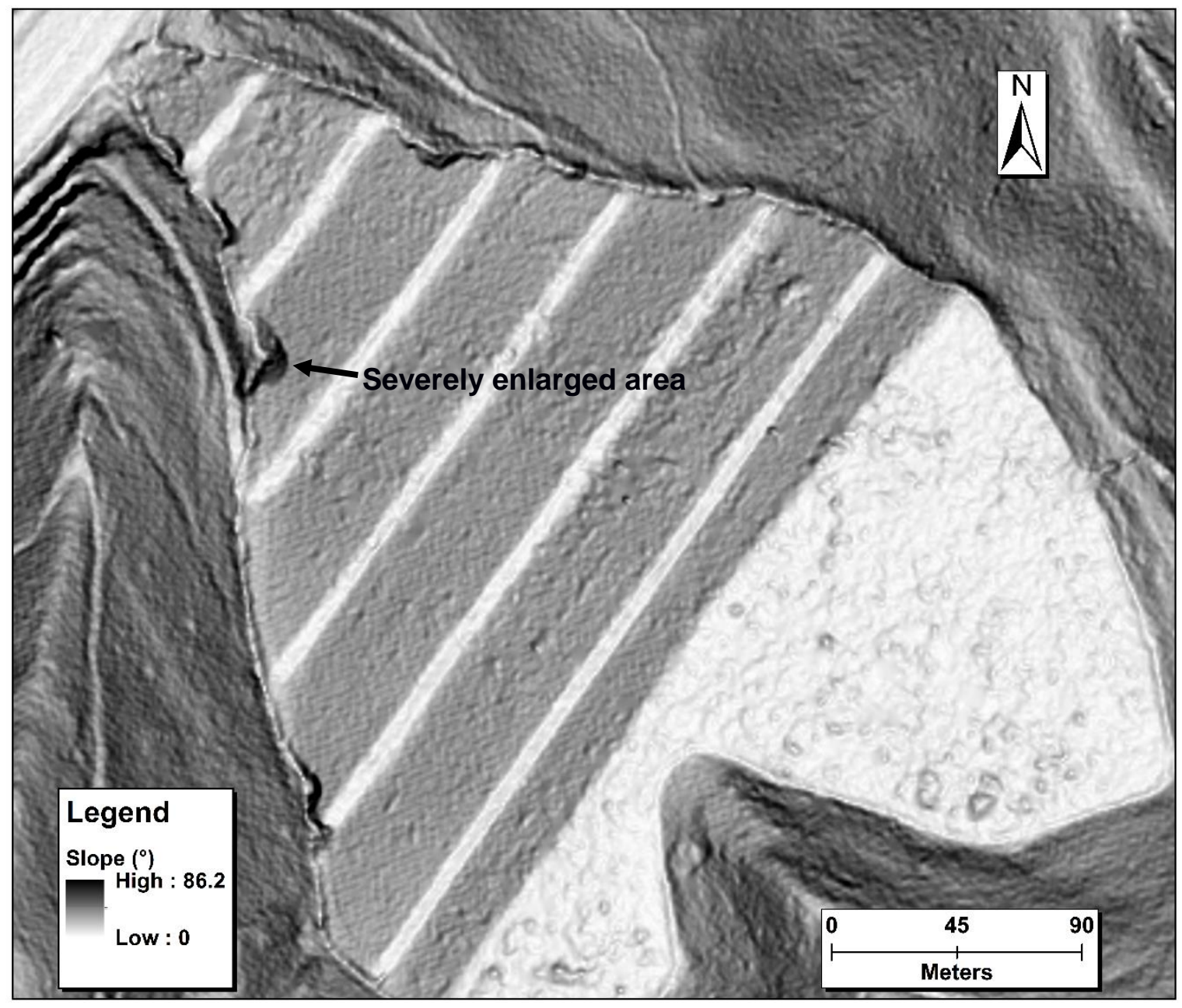

Figure 60. A $1 \mathrm{~m}$ LiDAR-derived slopeshade of the Whitman \#9 refuse fill. The refuse fill is composed of coal processing waste. Both constructed drains show signs of enlargement. The severely enlarged area is up to $\sim 20 \mathrm{~m}$ wide. 


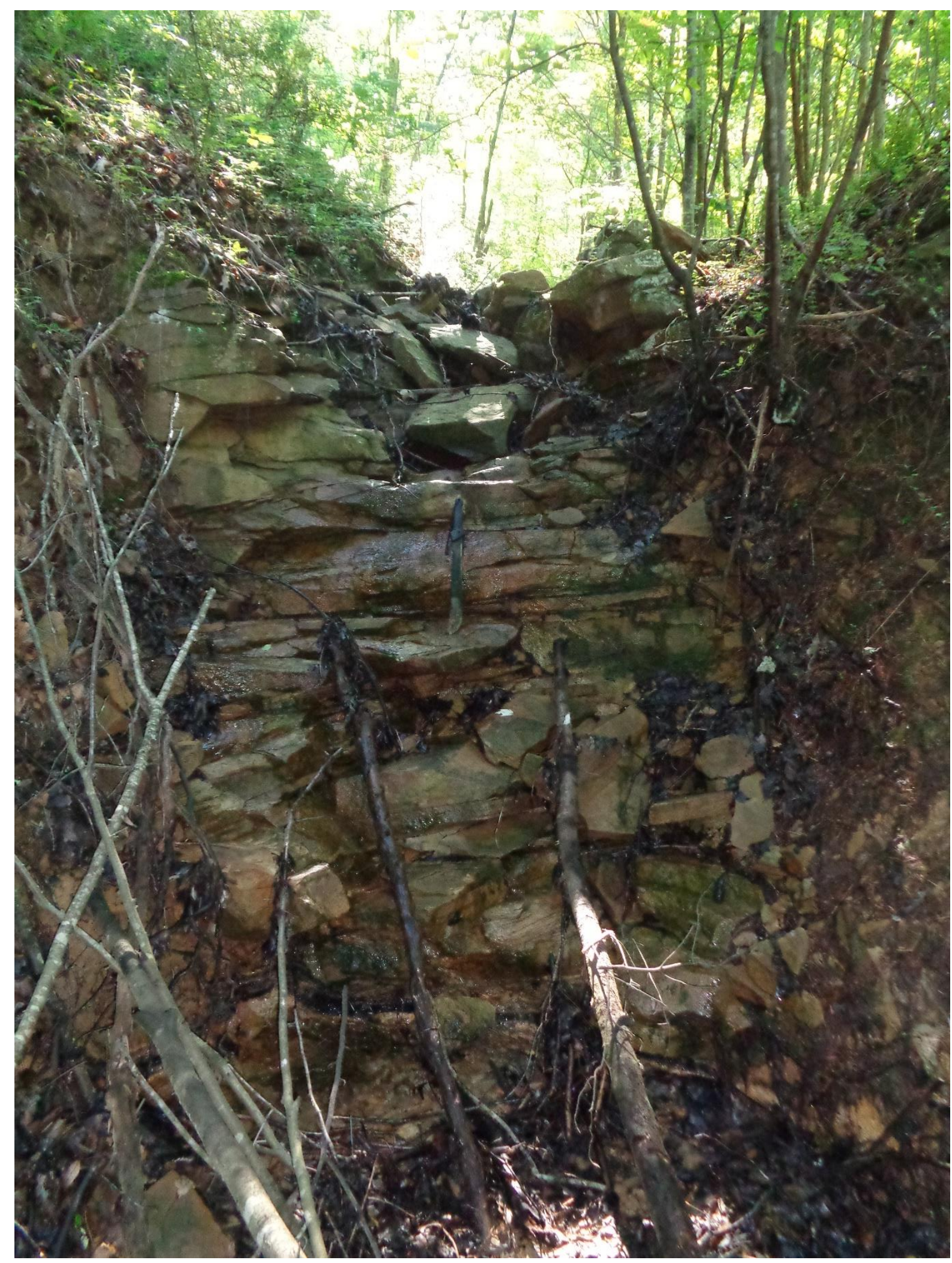

Figure 61 . Bedrock knickpoint within the north groin drain of Whitman \#9 refuse fill. The knickpoint is $\sim 3 \mathrm{~m}$ tall. The machete is $64 \mathrm{~cm}$ long. 


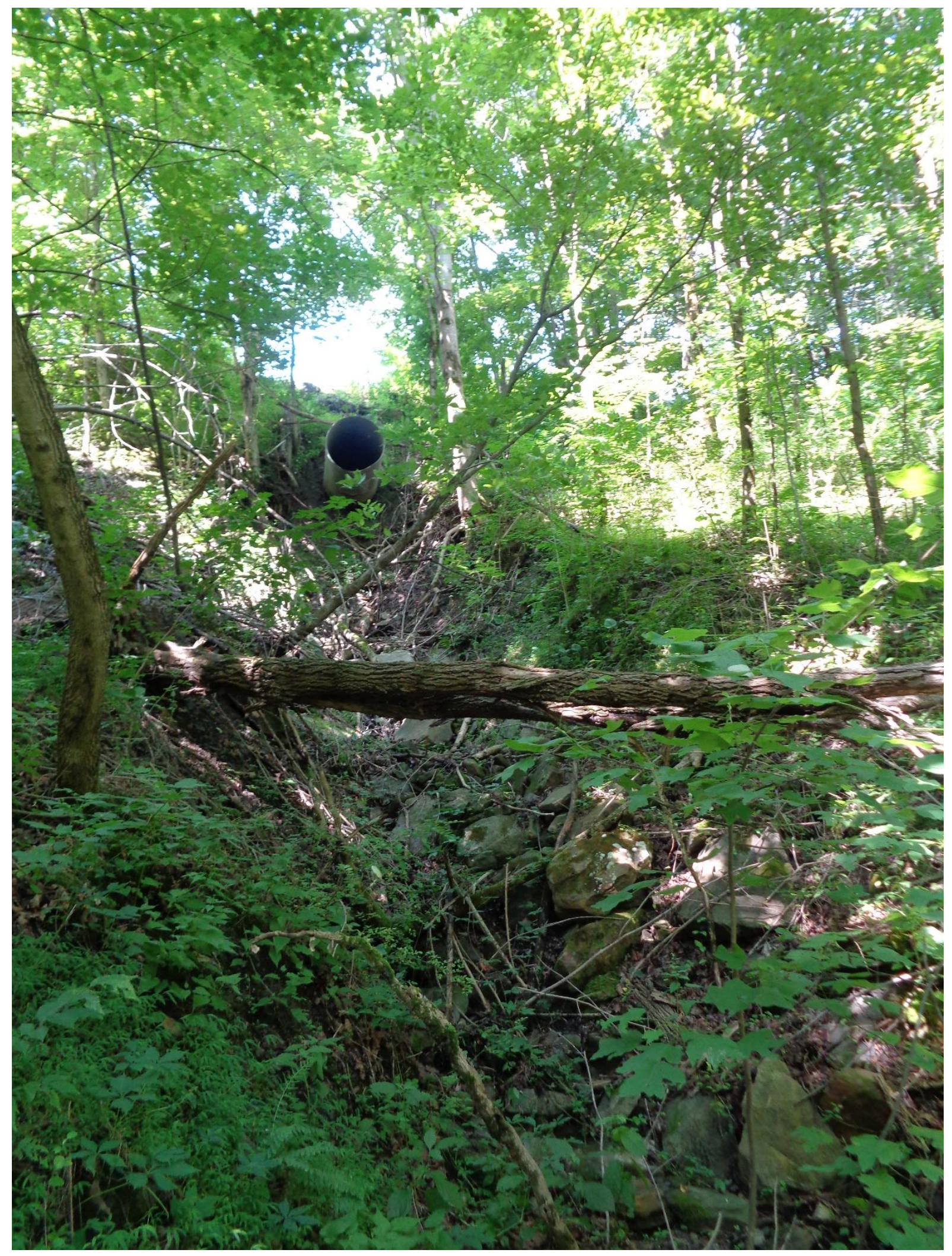

Figure 62. Looking upslope at a pipe from sediment cell along a haul road that discharges into the center drain of Whitman \#16, a refuse fill. The drain is abnormally wide and deep downslope. 


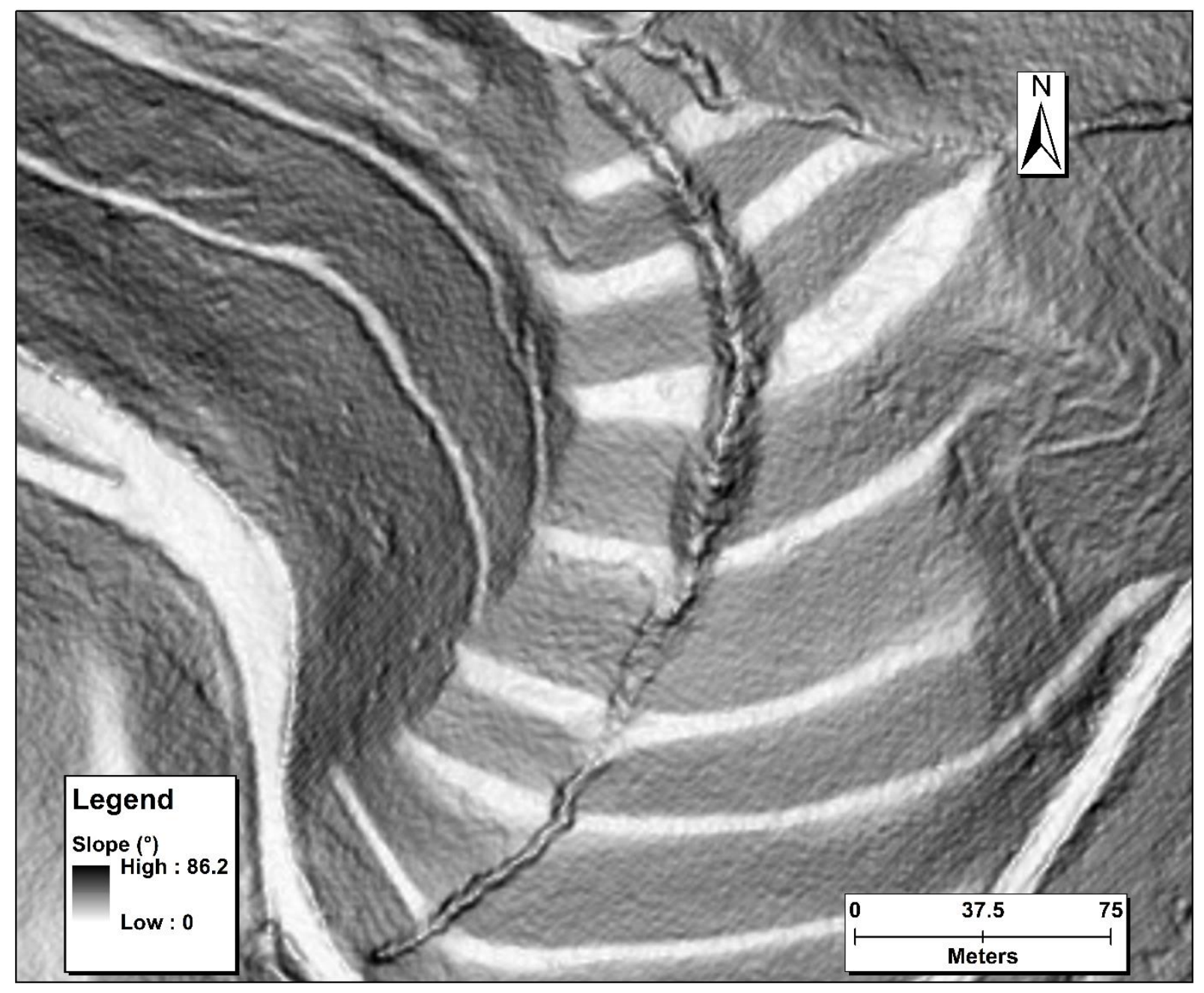

Figure 63. A $1 \mathrm{~m}$ LiDAR-derived slopeshade of the Whitman \#16 valley fill showing the enlarged center drain. The center drain is up to $\sim 8 \mathrm{~m}$ deep and $\sim 20 \mathrm{~m}$ deep but retains emplaced boulders. 


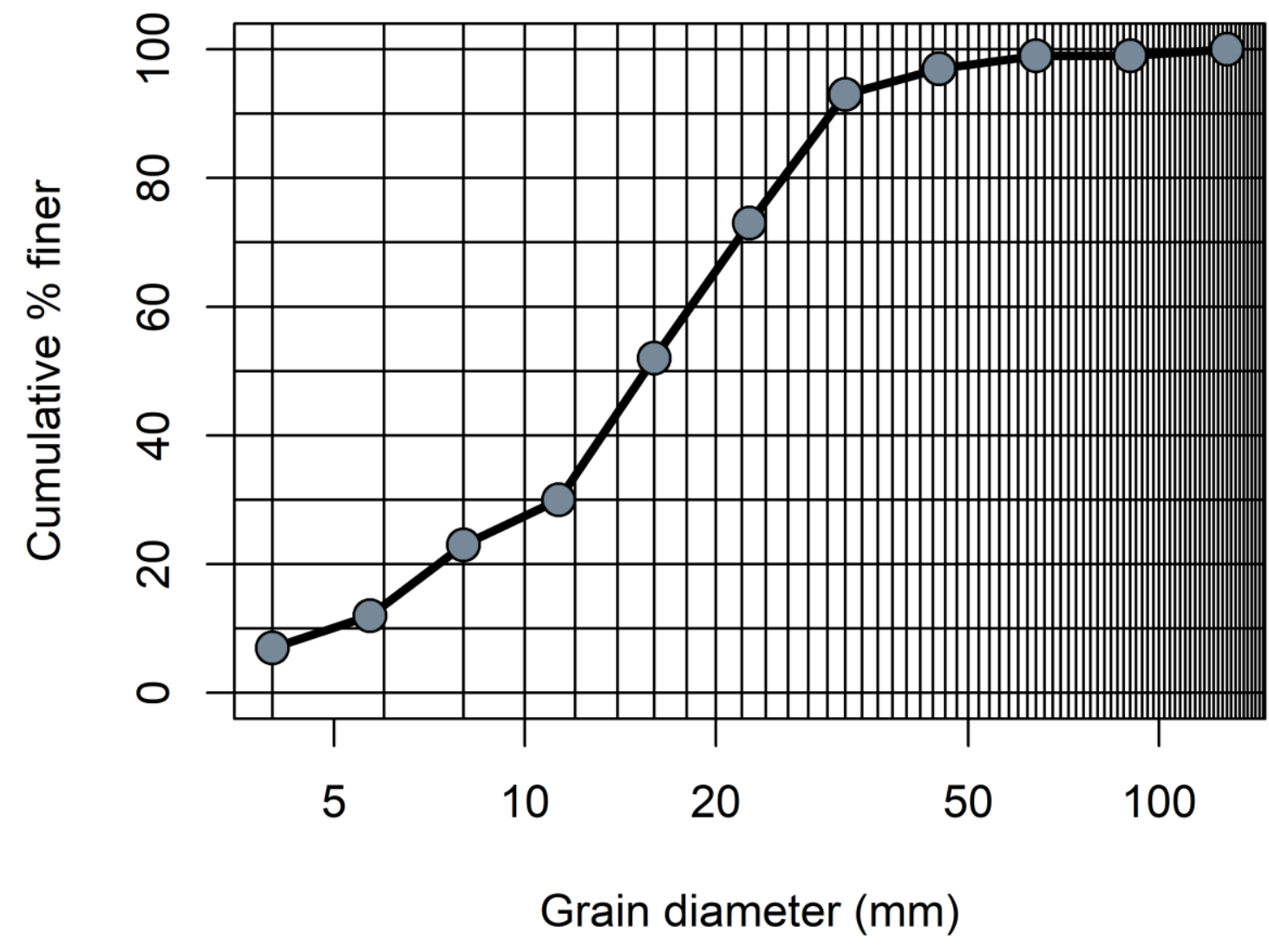

Figure 64. Cumulative grain size distribution plot for the pebble count conducted in the inset fluvial channel of the Whitman \#18 center drain. This pebble count has a median grain size $\left(D_{50}\right)$ of 16 $\mathrm{mm}$, which was the average among the 13 pebble counts. The vertical lines occur every $2 \mathrm{~mm}$. 


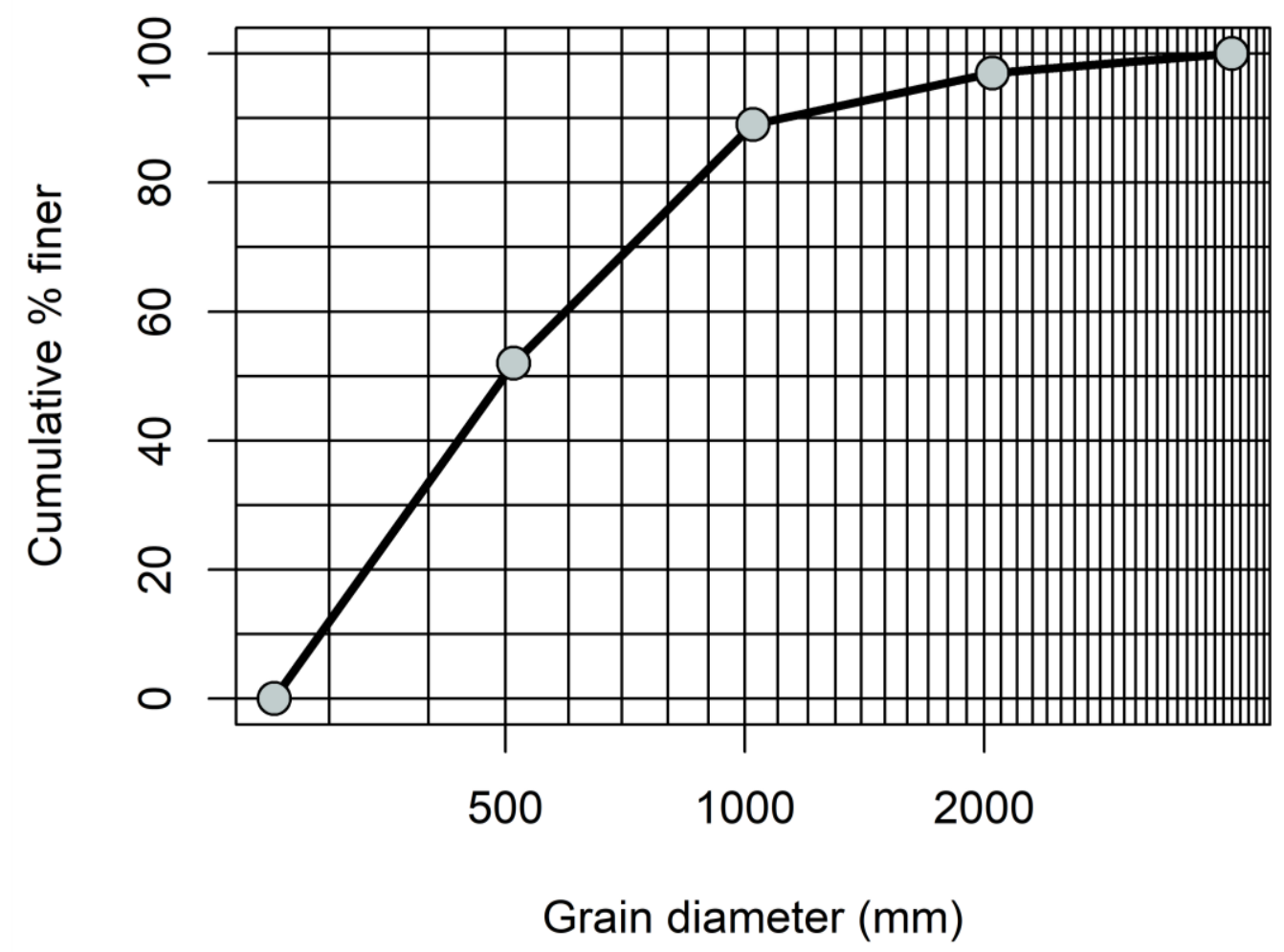

Figure 65. Cumulative grain size distribution of boulder count conducted in the north groin drain of the Whitman \#8 valley fill. The boulder count data was used in the parameterization of the CAESAR-Lisflood landscape evolution model. 


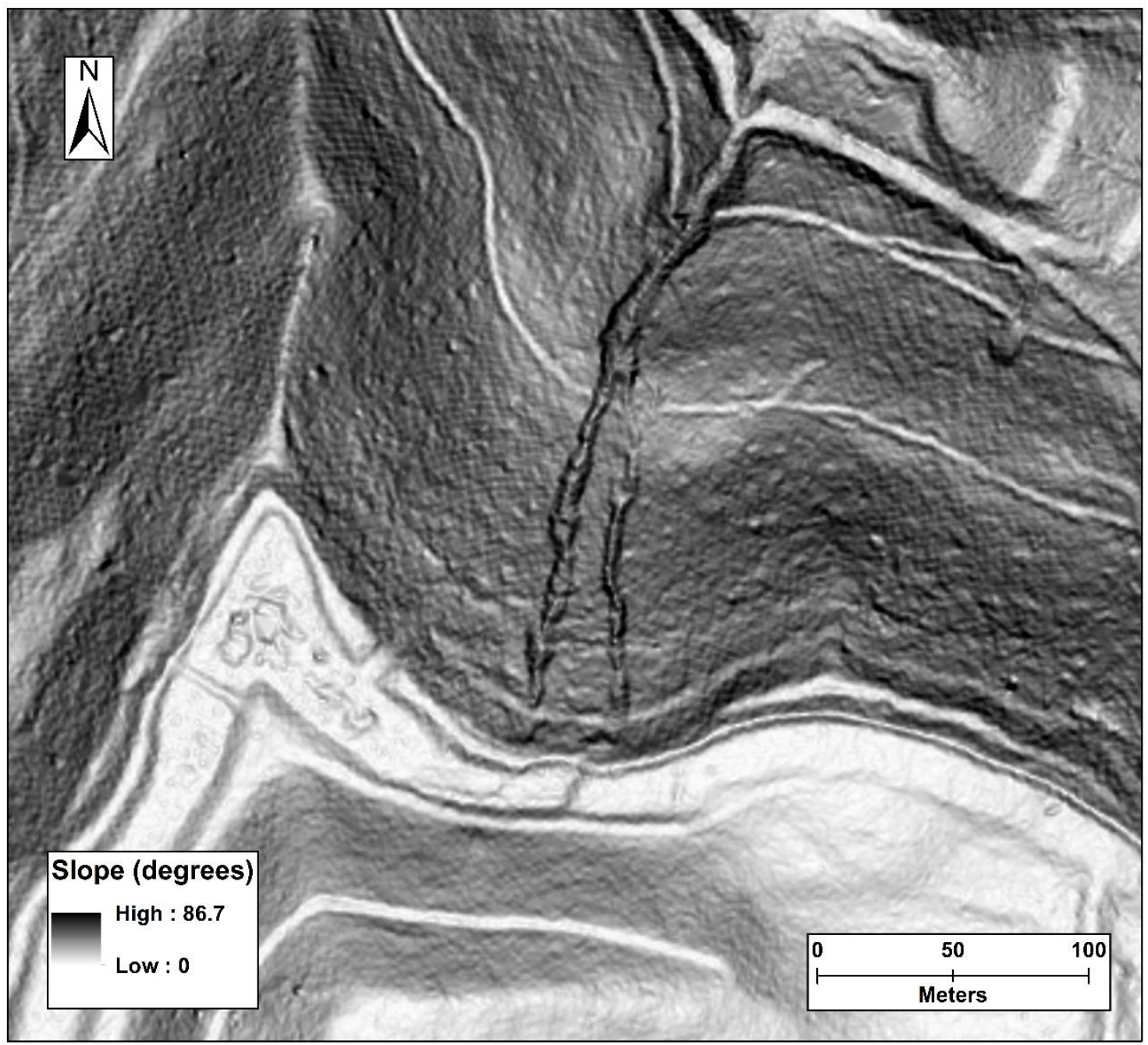

Figure 66. Gullies eroded into a colluvial sideslope in the Clay-Nicholas dataset. The gullies are most likely associated with the retention cells in the lower half of the image. Gully formation due to MTR/VF drainage systems was the most common, causing $53 \%$ of total gully formation. 


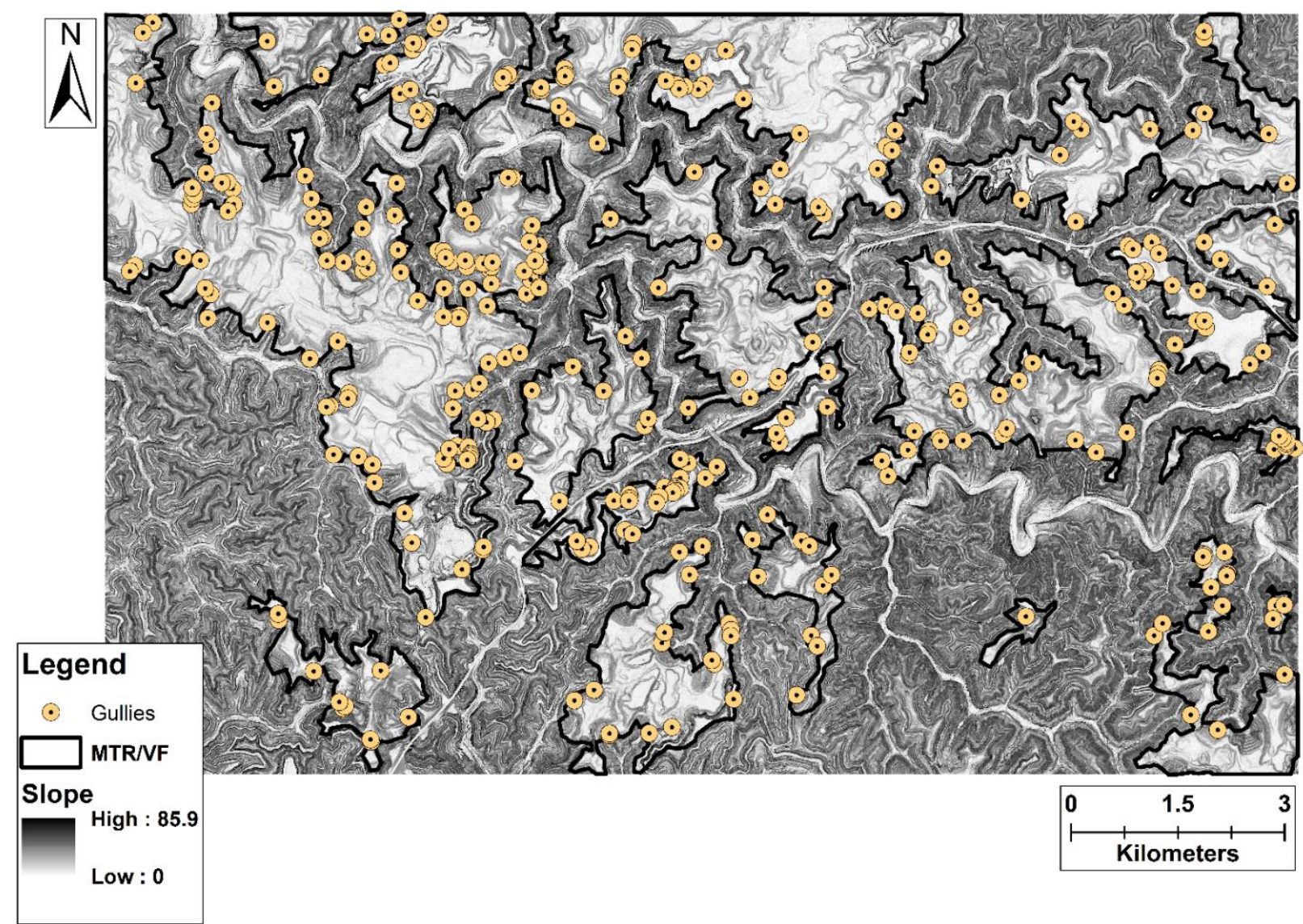

Figure 67. A $1 \mathrm{~m}$ slopeshade of the Perry-Knot-Breathitt, Kentucky, dataset showing the location of gully heads. The Perry-Knott-Breathitt dataset had 349 manually identified gullies on MTR/VF land and had the highest measure of gullies per $\mathrm{km}^{2}$ with 5.0. 


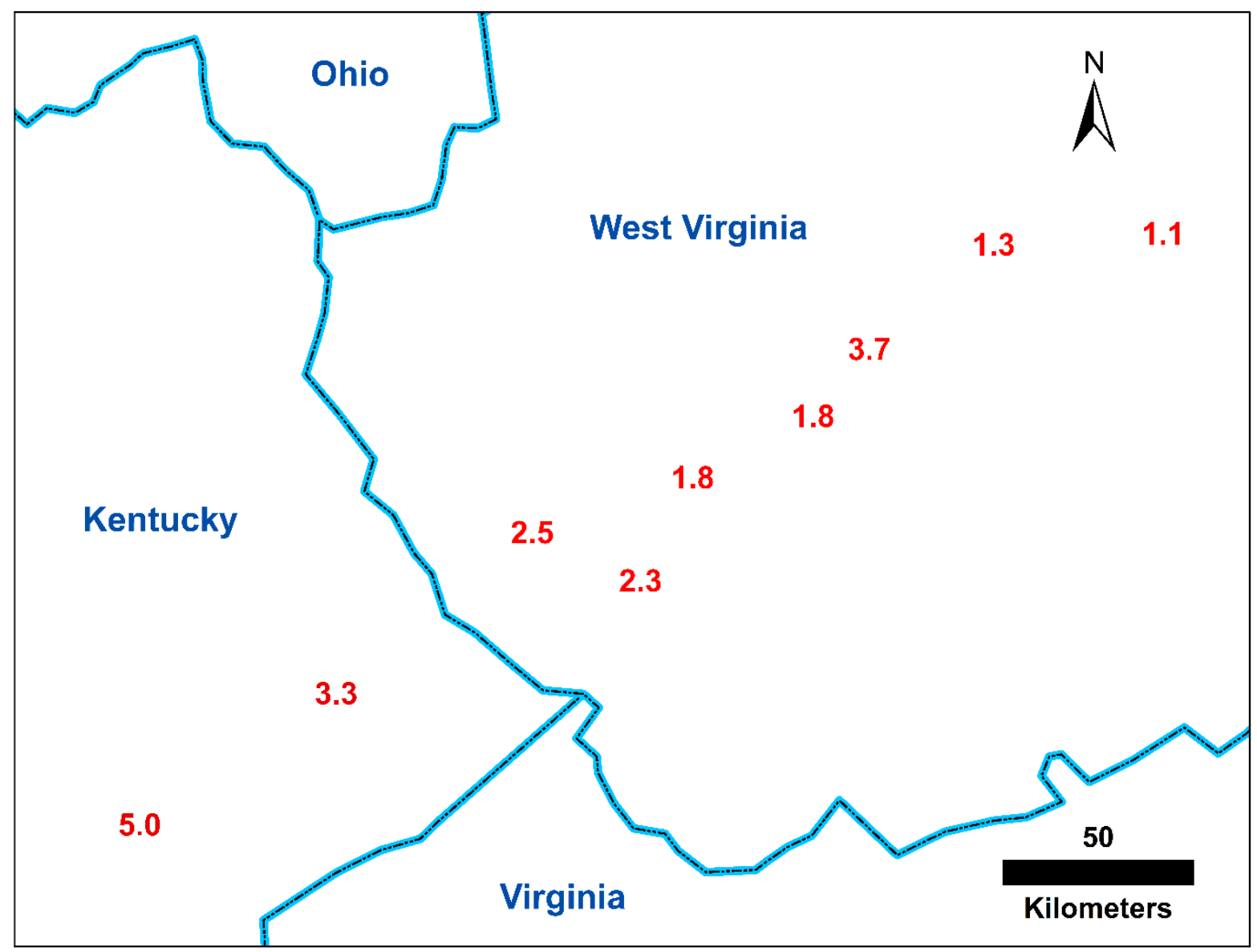

Figure 68. An increasing trend in gullies per $\mathrm{km}^{2}$ in the LiDAR datasets was observed from the Birch River dataset in central West Virginia to the Perry-Knott-Breathitt dataset in eastern Kentucky. The value of 3.7 gullies per $\mathrm{km}^{2}$ is from the Cannelton dataset, which has a high concentration of older valley fills. 


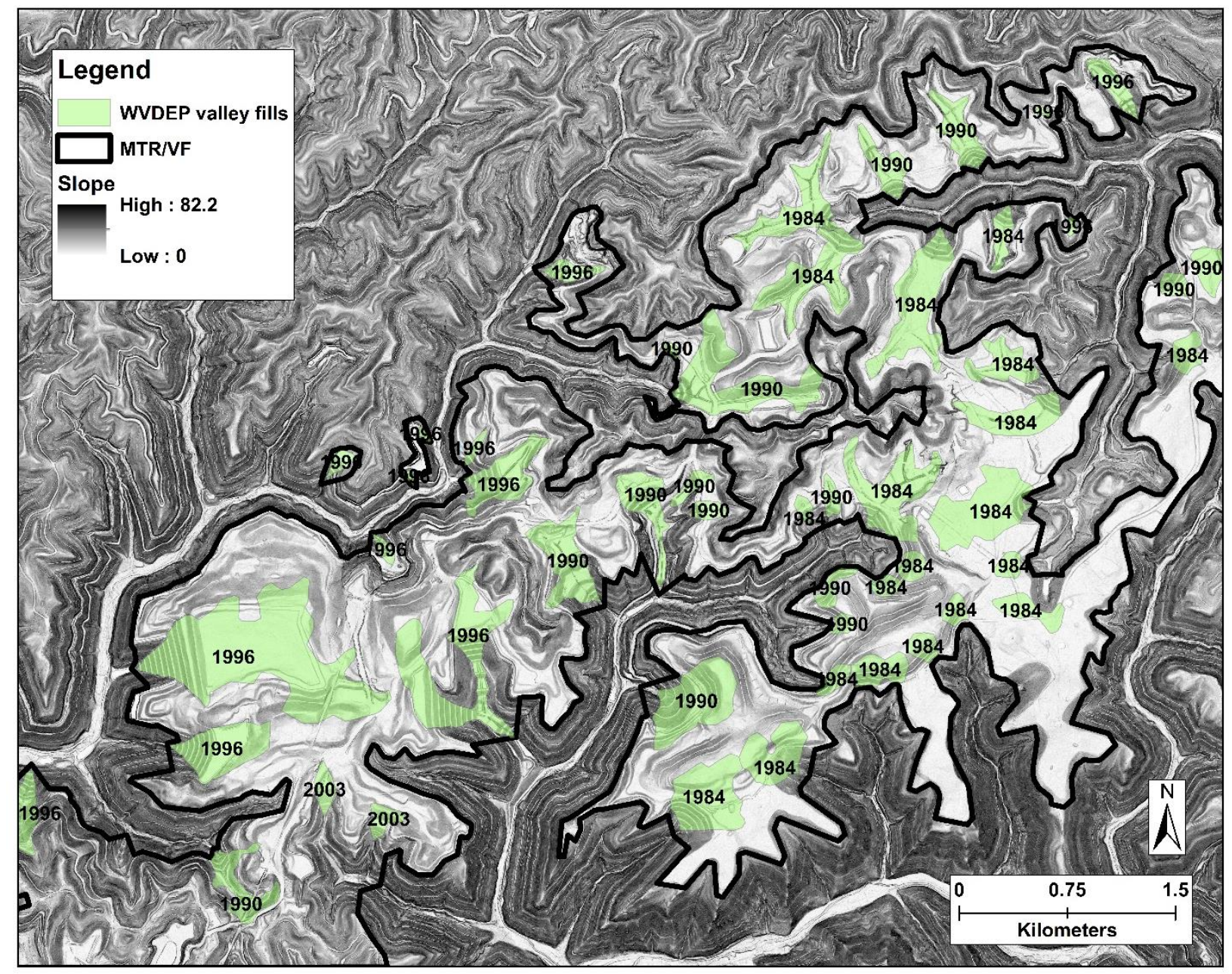

Figure 69. A 1 m LiDAR-derived slopeshade of the Cannelton, West Virginia, dataset showing the remotely sensed valley fills and their ages as determined by the West Virginia Department of Environmental Protection. The Cannelton dataset showed an anomalously elevated level of gullies per $\mathrm{km}^{2}$ with 3.7, which did not conform to the trend shown in Figure 71. Cannelton has a high density of older valley fills (1984 and 1990), which may explain the elevated level of gully erosion. 


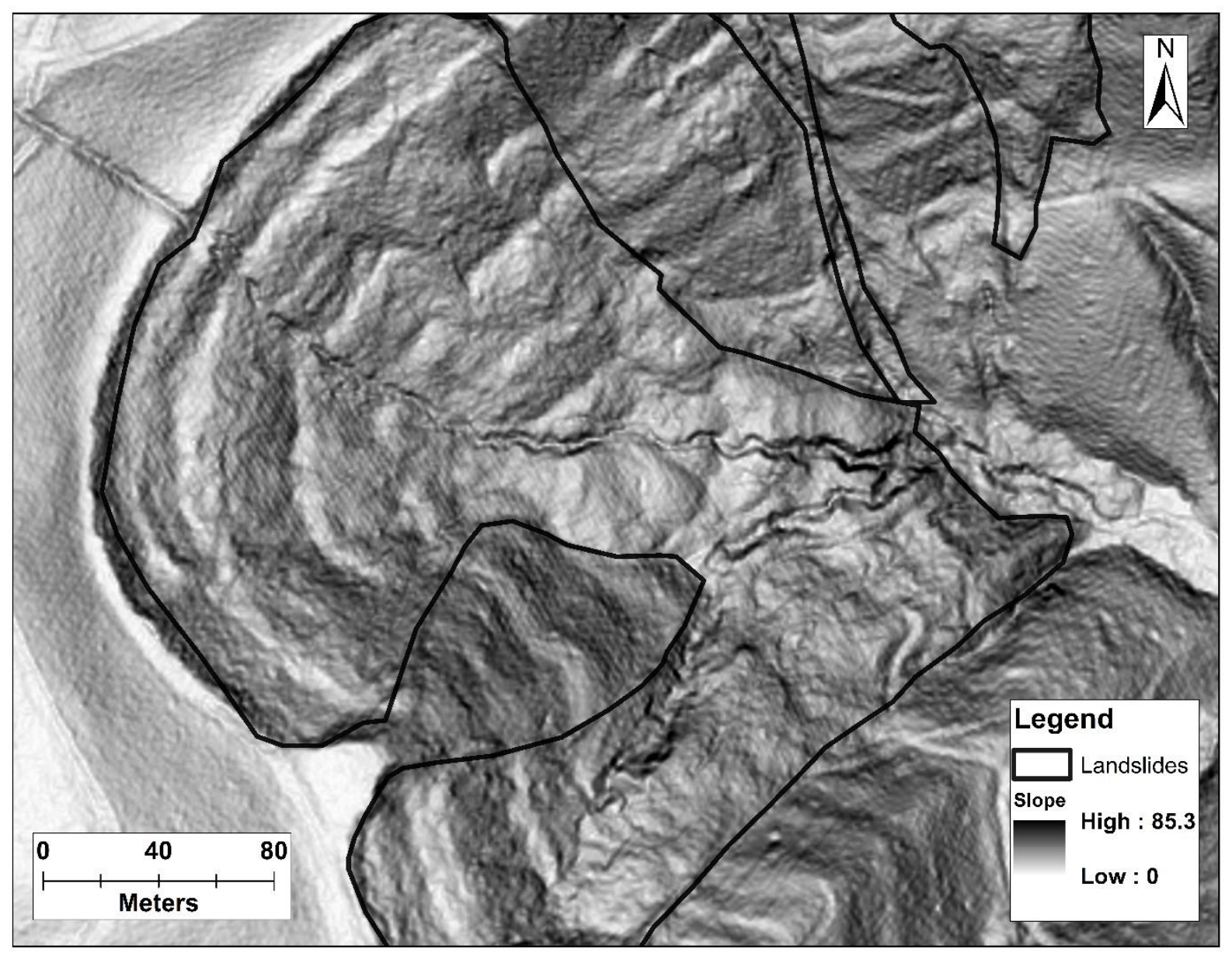

Figure 70. Gullies occurring in landslides were not quantified in the gully classification described previously. LiDAR slopeshade from the Floyd-Pike, Kentucky, dataset. 


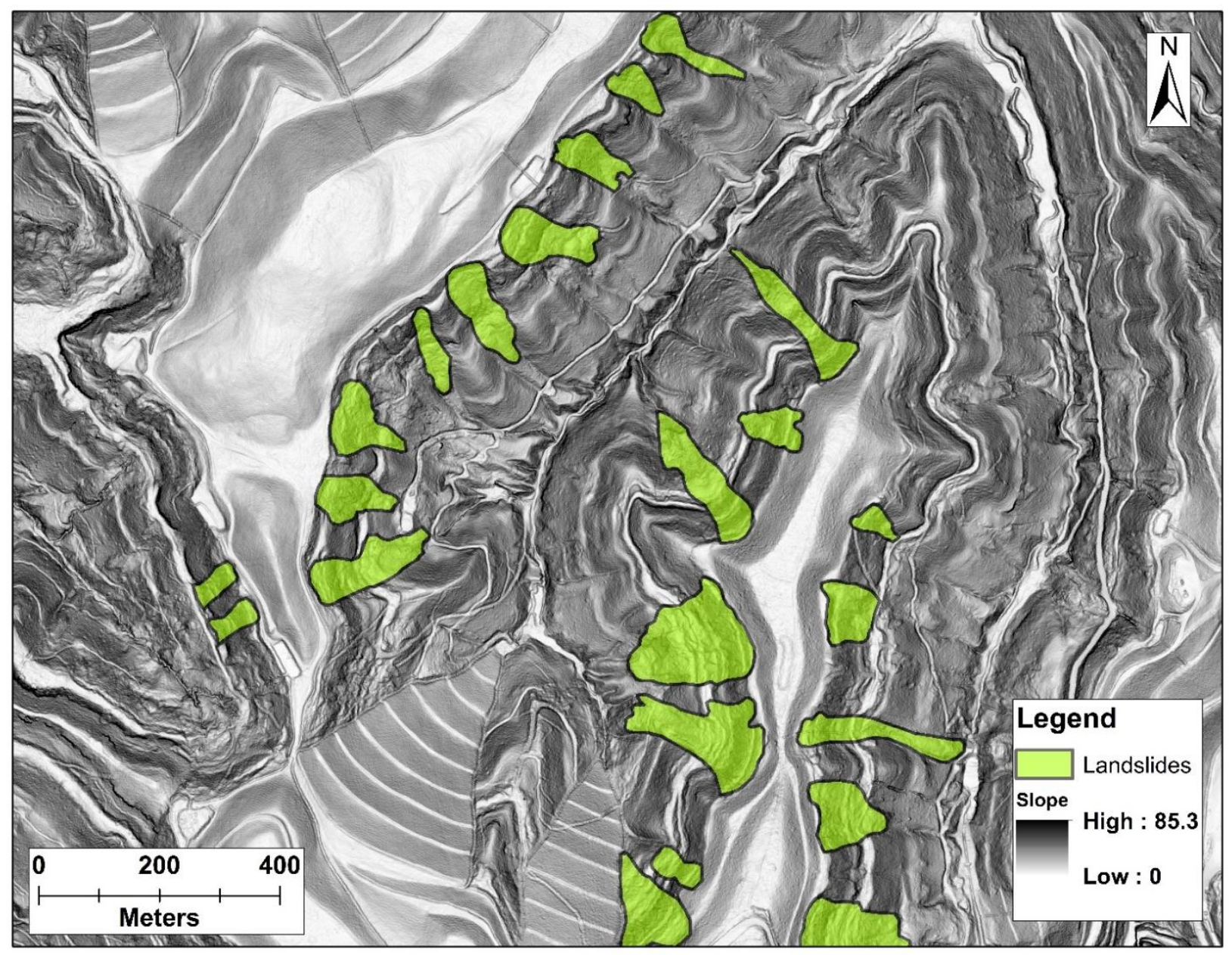

Figure 71. LiDAR-derived slopeshade displaying the extensive mass wasting observed in the Floyd-Pike, Kentucky, dataset. The Floyd-Pike dataset had 125 identified landslides in $\sim 32 \mathrm{~km}^{2}$ of MTR/VF affected land. 


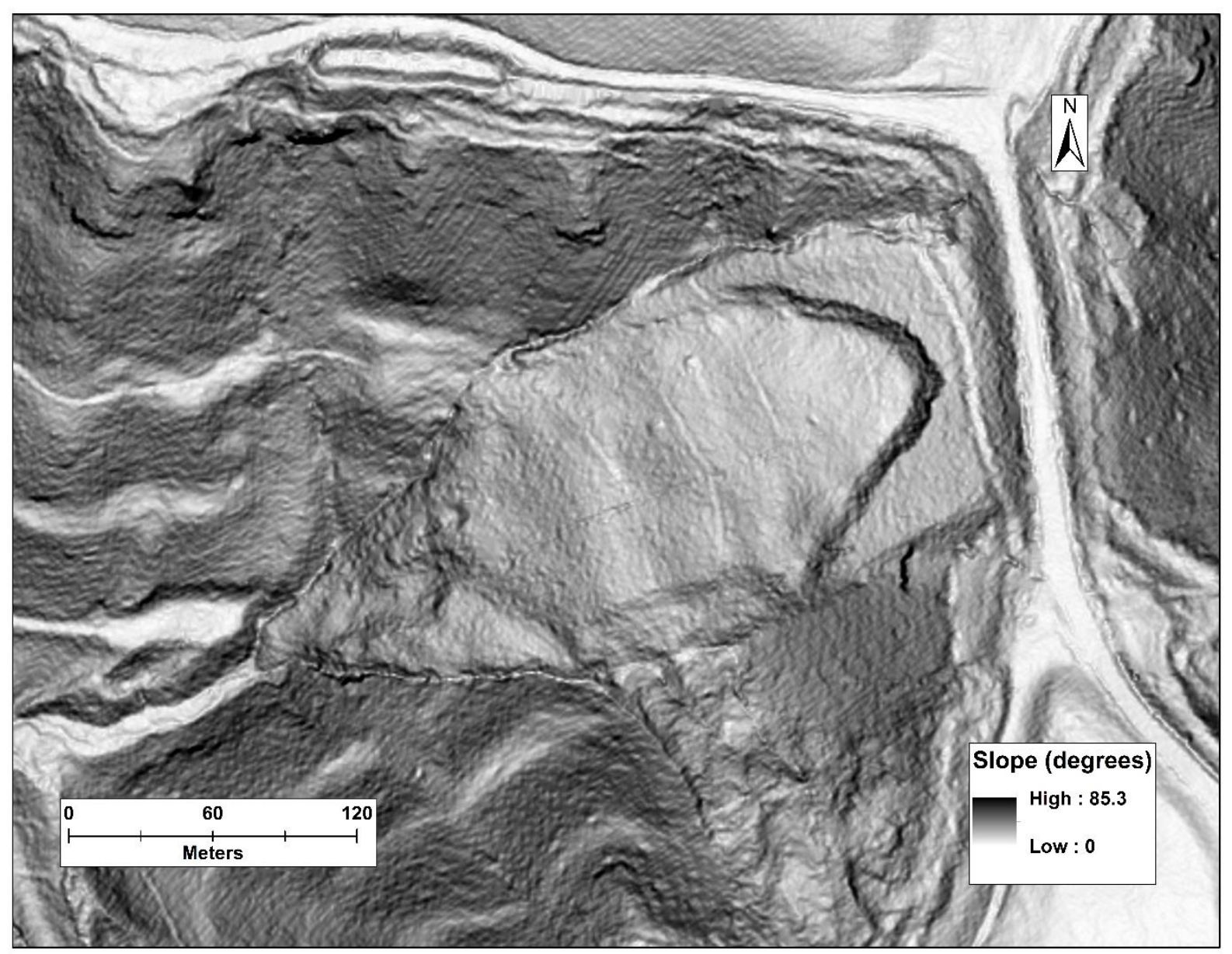

Figure 72. LiDAR-derived slopeshade of a landslide within a valley fill in the Floyd-Pike, Kentucky, dataset. The main scarp of the landslide has a maximum height of $\sim 9.5 \mathrm{~m}$. 


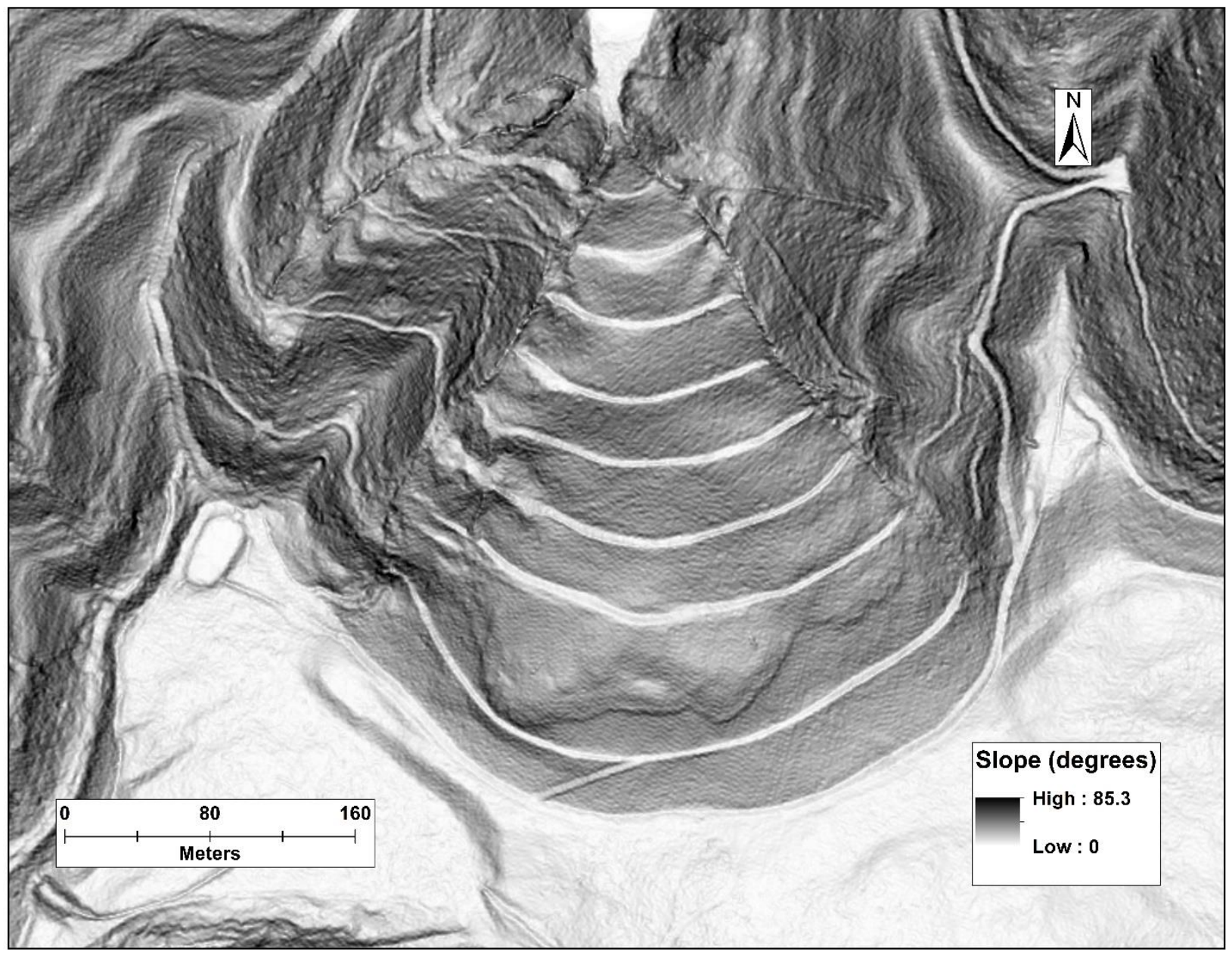

Figure 73. LiDAR-derived slopeshade of deformation within a valley fill face from the Floyd-Pike dataset. A possible tension crack or small main scarp runs along most of the width of the valley fill. Tension cracks are evidence of incipient mass wasting and were included among the landslides identified from LiDAR. 


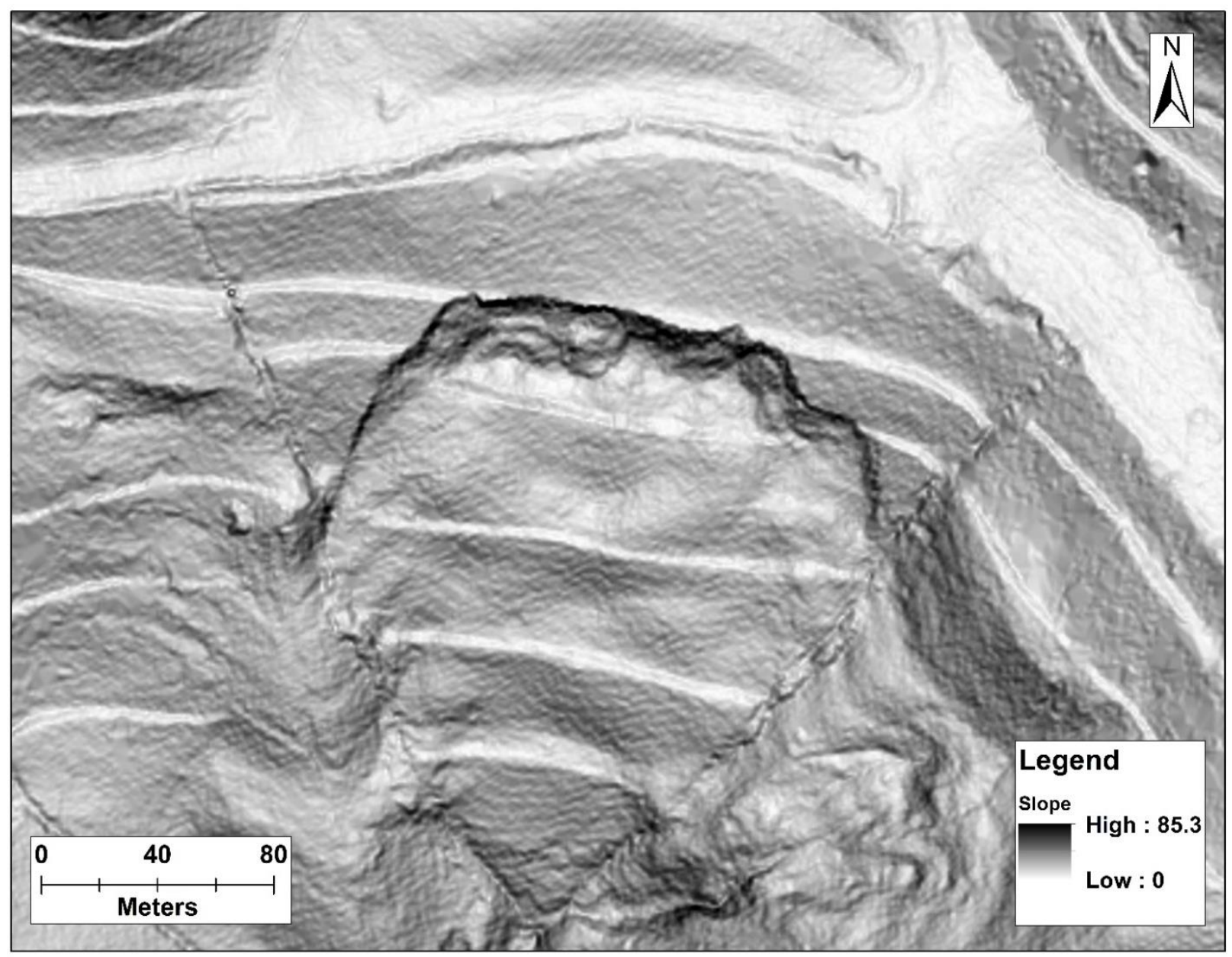

Figure 74. LiDAR-derived slopeshade of large main scarp within a valley fill from the Floyd-Pike, Kentucky, dataset. The main scarp is $\sim 13 \mathrm{~m}$ in height and $\sim 126 \mathrm{~m}$ from flank to flank. 


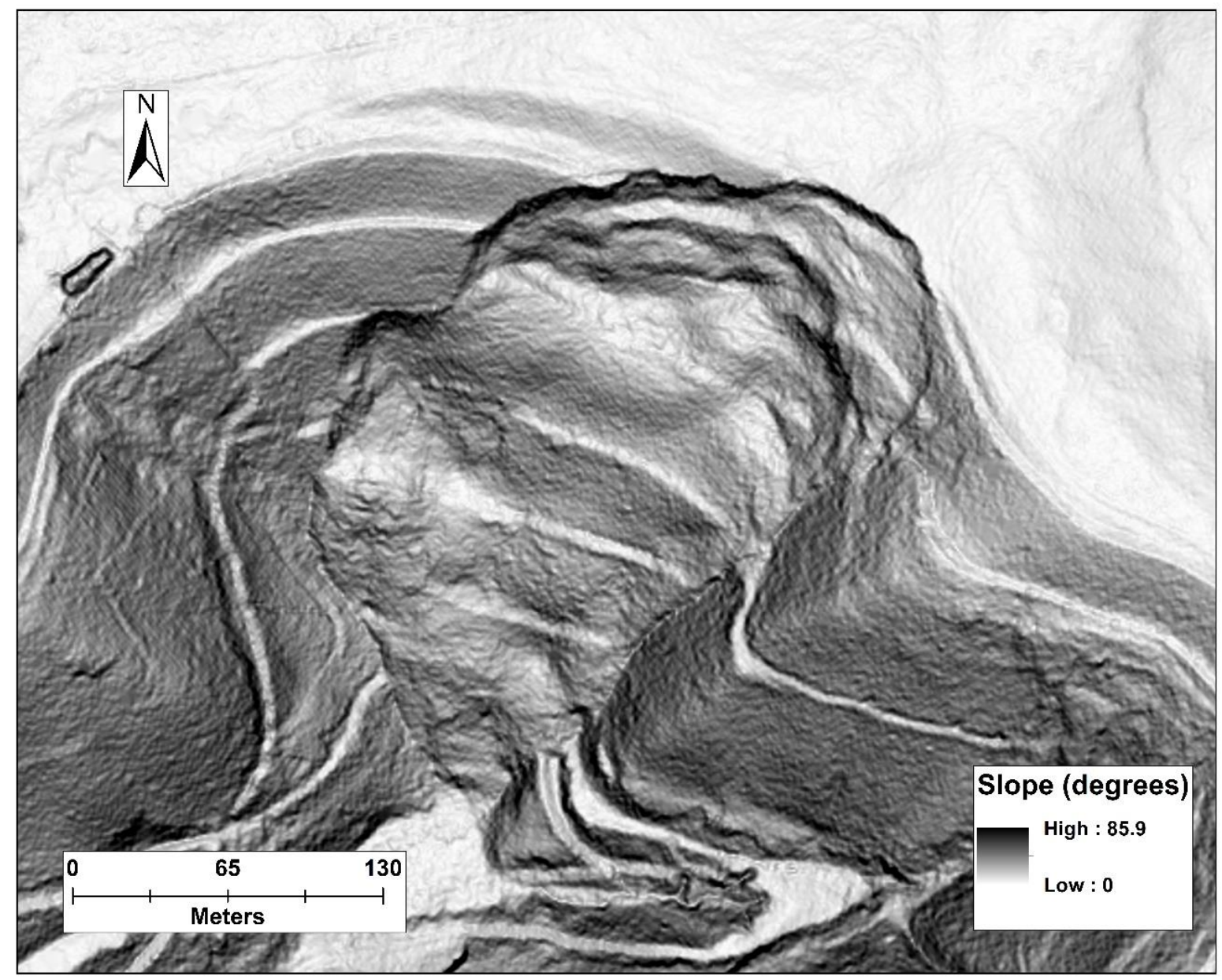

Figure 75. LiDAR-derived slopeshade of a large landslide within a valley fill face from the PerryKnott-Breathitt, Kentucky, dataset. The landslide induced a near complete loss of the constructed topography of the valley fill, including covering of the constructed drains. 


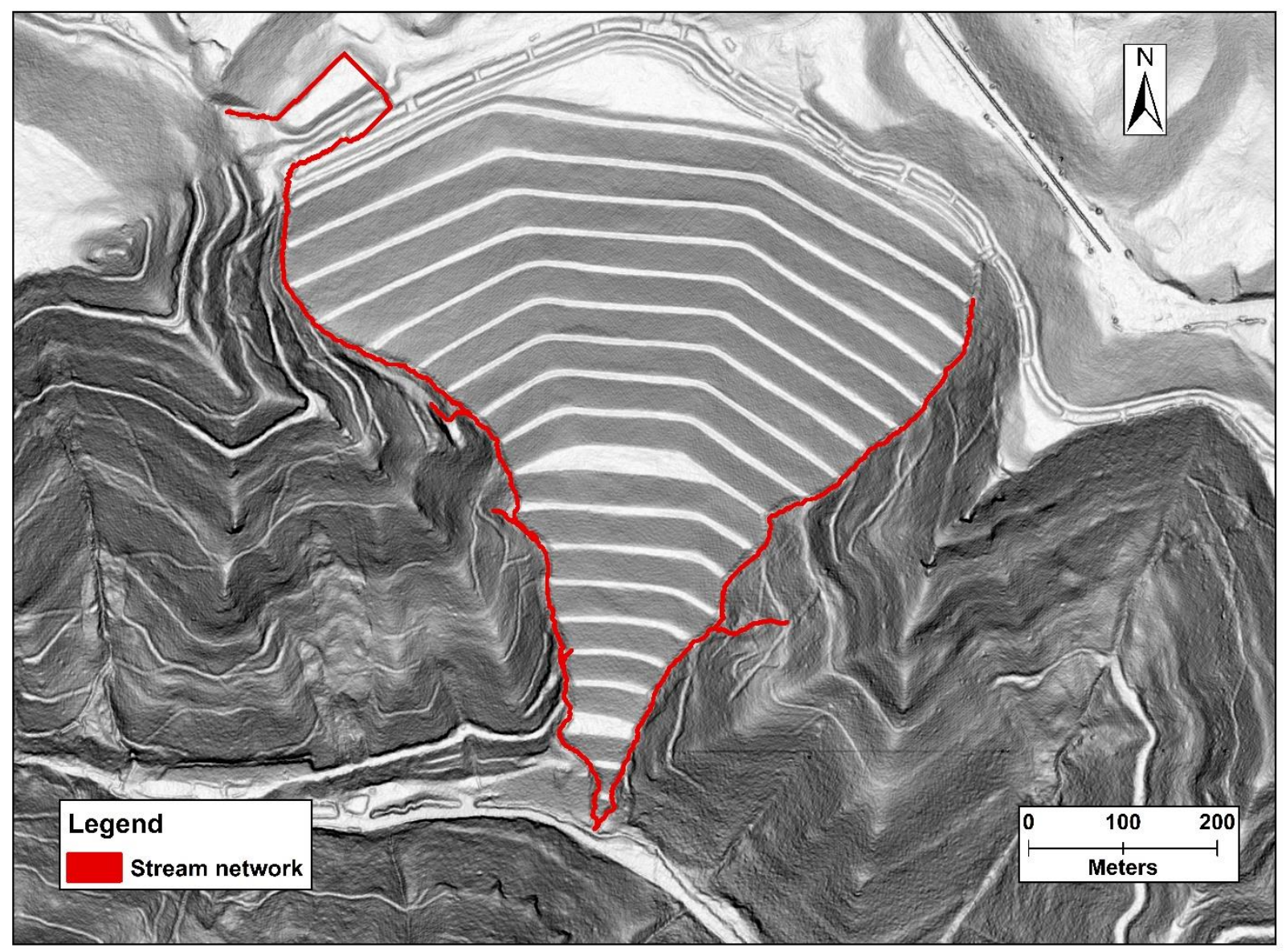

Figure 76. LIDAR-derived slopeshade of an Amherstdale dataset valley-filled catchment showing an example of an extracted stream channel network using the geometric algorithm of Grieve et al. (2016a). 


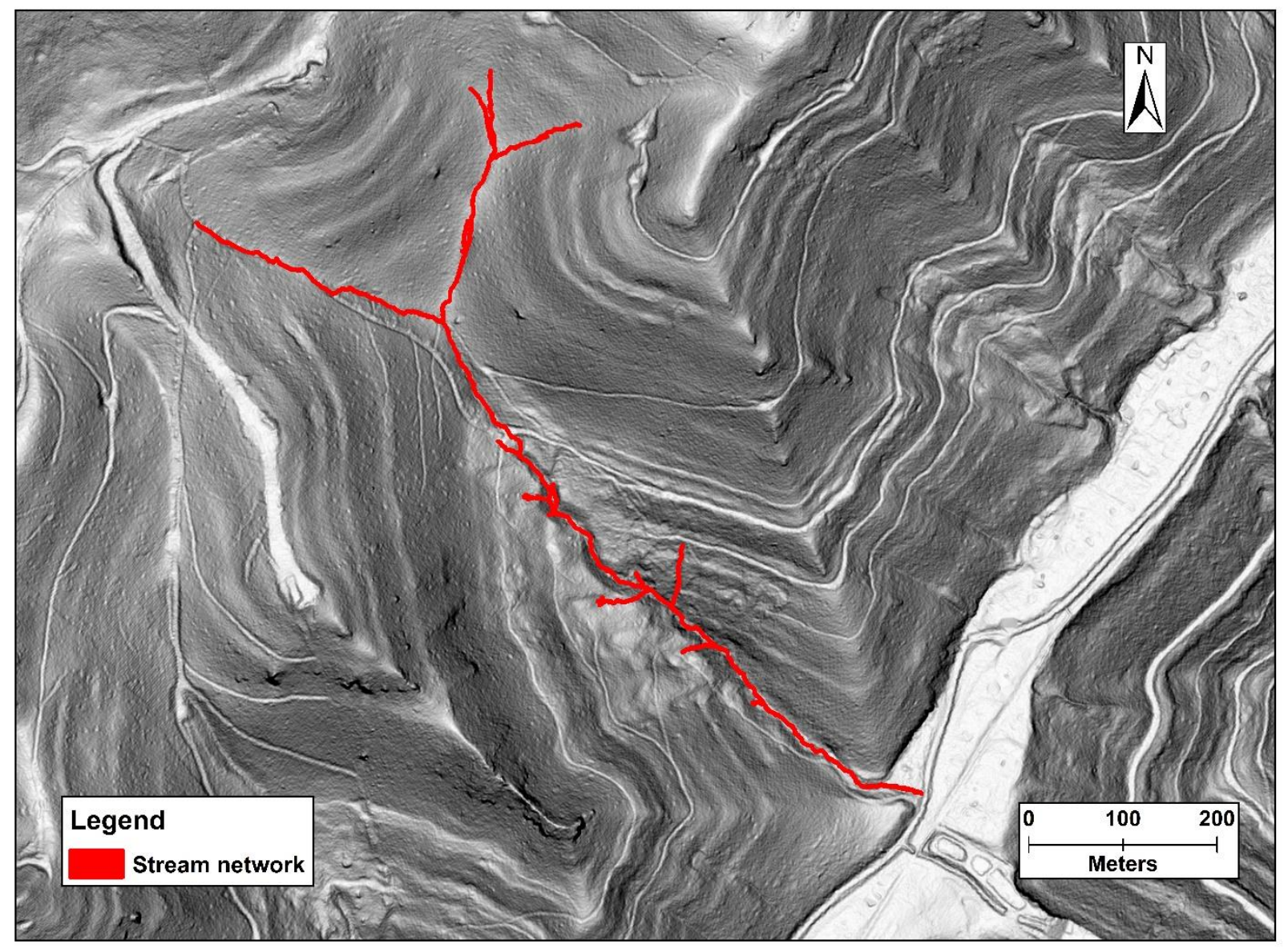

Figure 77. LiDAR-derived slopeshade of a "less disturbed" catchment in the Amherstdale dataset showing an extracted stream channel network. No catchments in either the Holden or Amherstdale were truly pristine as evidence for legacy mining and timbering was ubiquitous. Less disturbed in this case means that there is no valley fill within the catchment. 


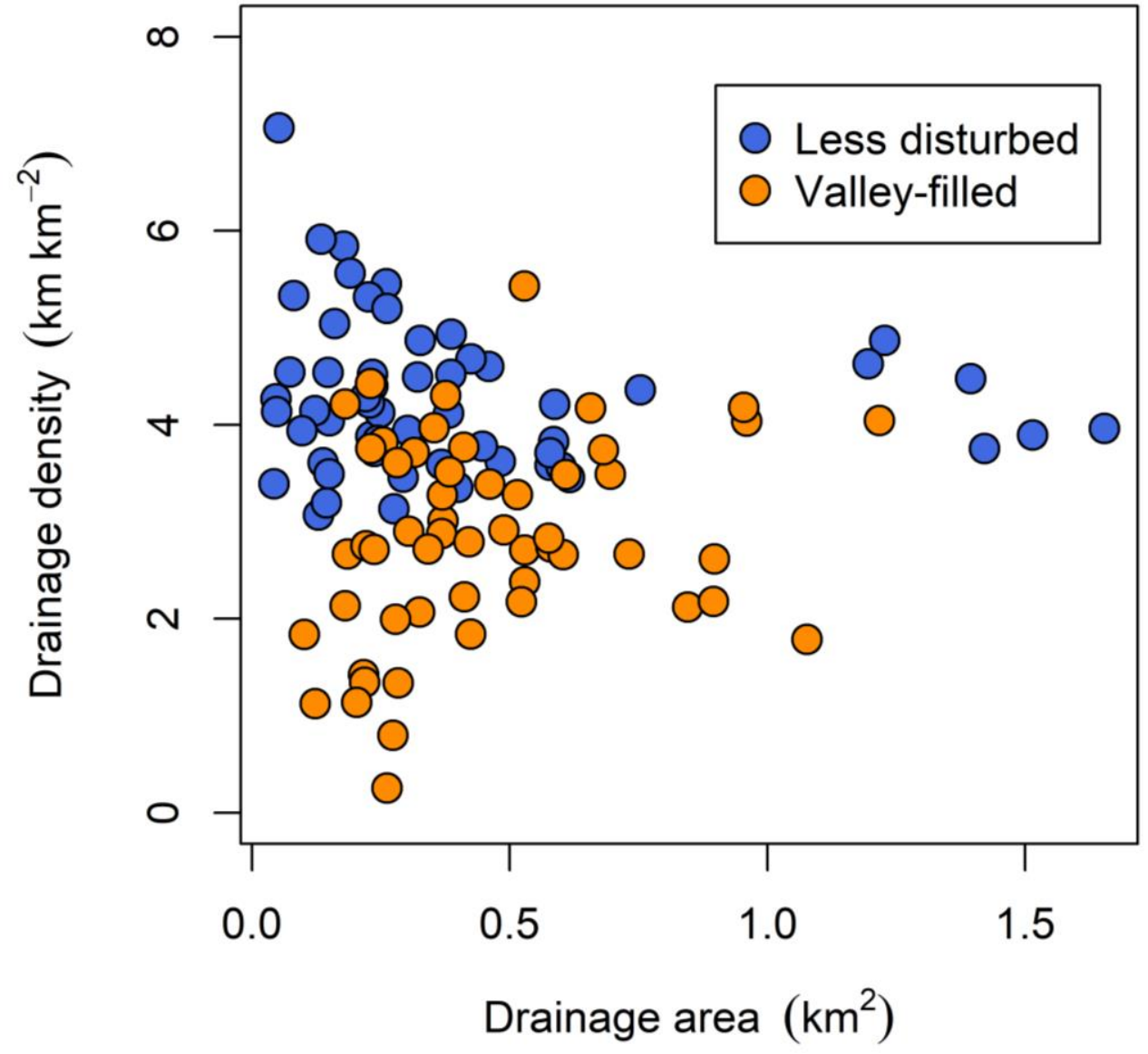

Figure 78. Plot of drainage density and drainage area of less disturbed and valley-filled catchments from both the Holden and Amherstdale datasets. Valley-filled catchments show lower drainage density relative to less disturbed catchments, especially at lower drainage areas. 


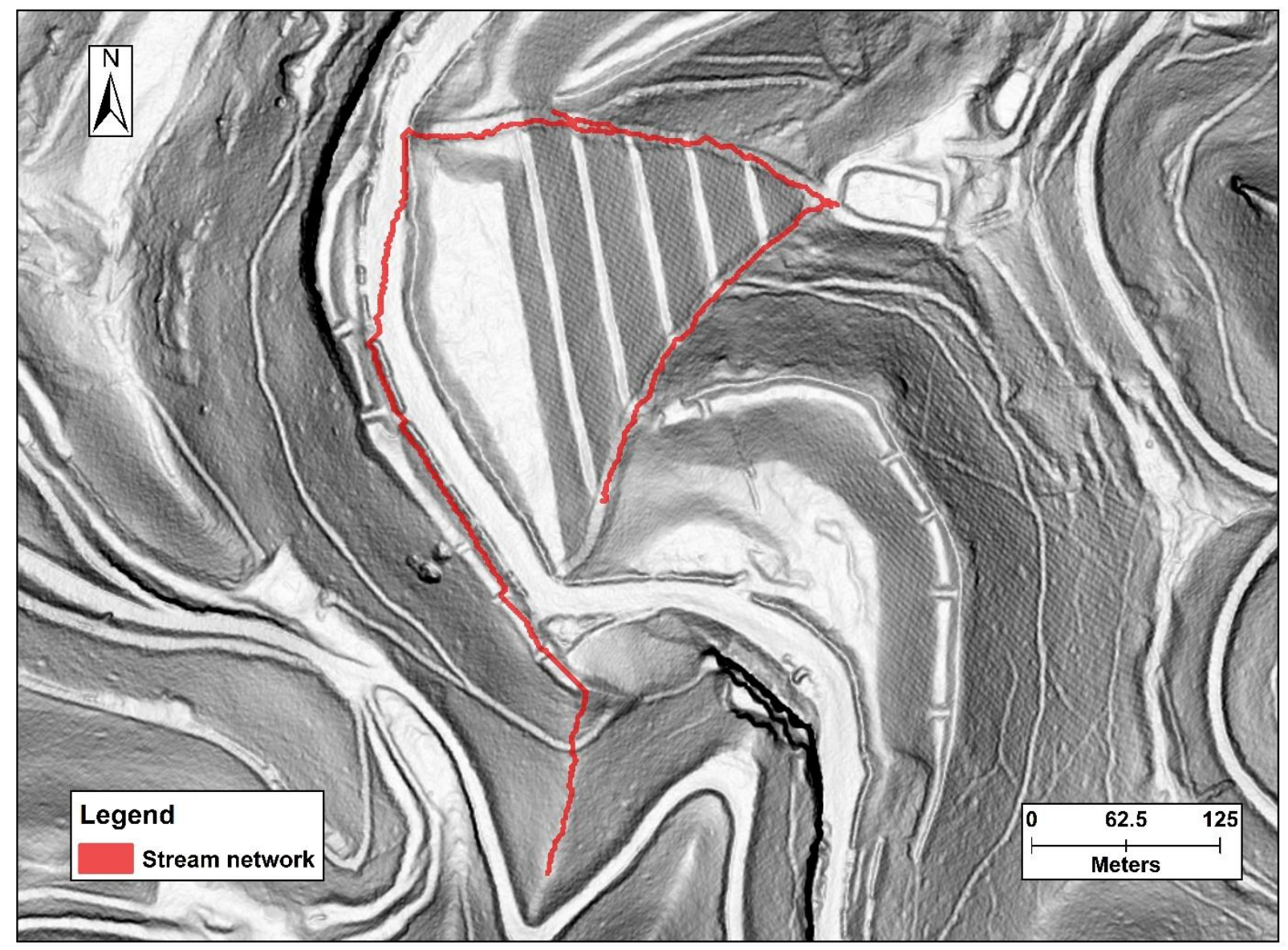

Figure 79. LiDAR-derived slopeshade of an Amherstdale valley-filled catchment showing the overestimation of stream length using the algorithm of Grieve et al. (2016a). The stream channel starting close to bottom of the image goes through several retention cells to the right of the haul road above the valley fill because the DEM is filled before the channel extraction algorithm is performed. 


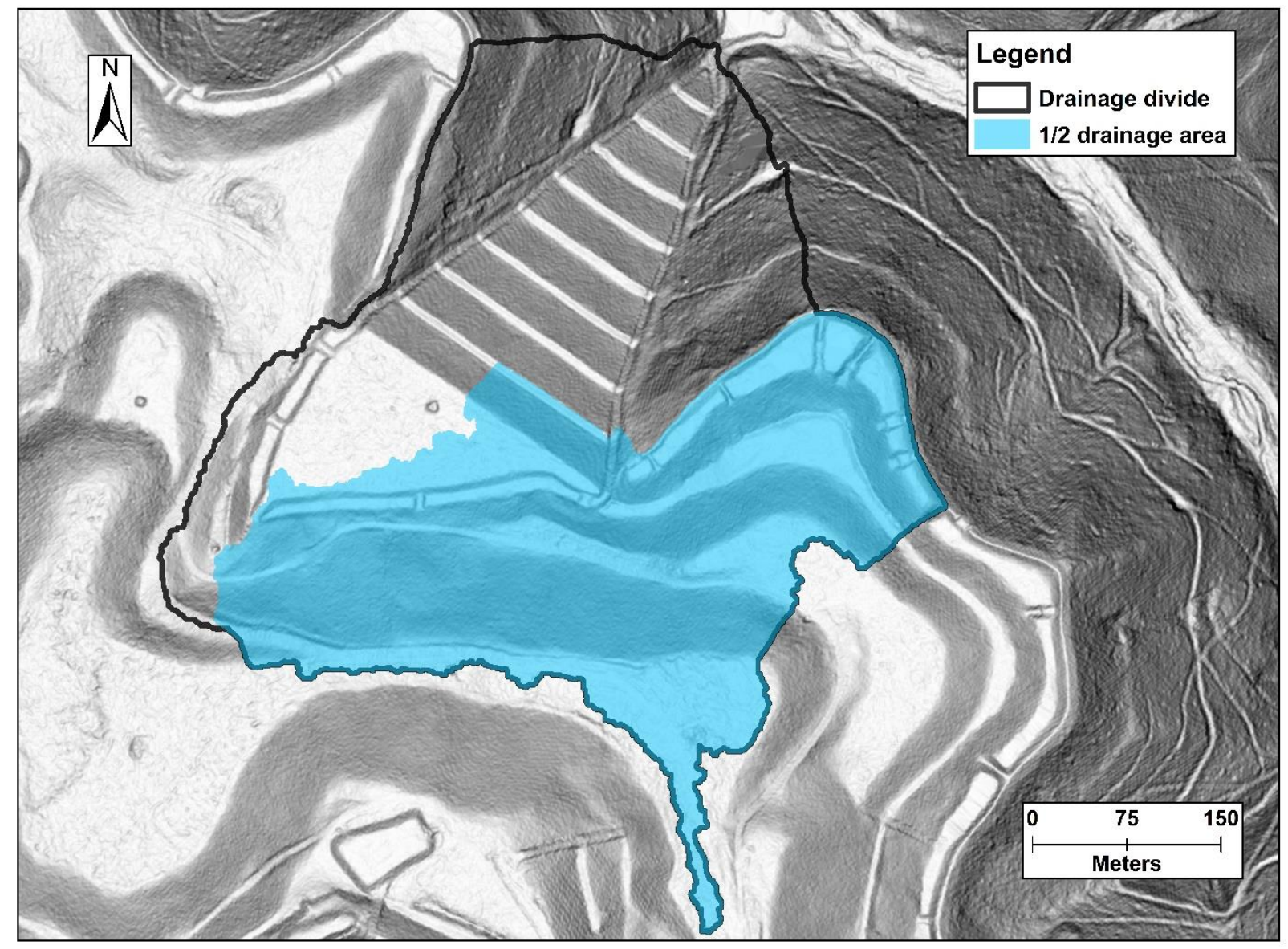

Figure 80. LiDAR-derived slopeshade of a valley-filled catchment from the Amherstdale dataset showing the catchment midpoint occurring high within the catchment. Valley-filled catchments showed higher relief between the catchment midpoint and the outlet when compared to less disturbed catchments. 


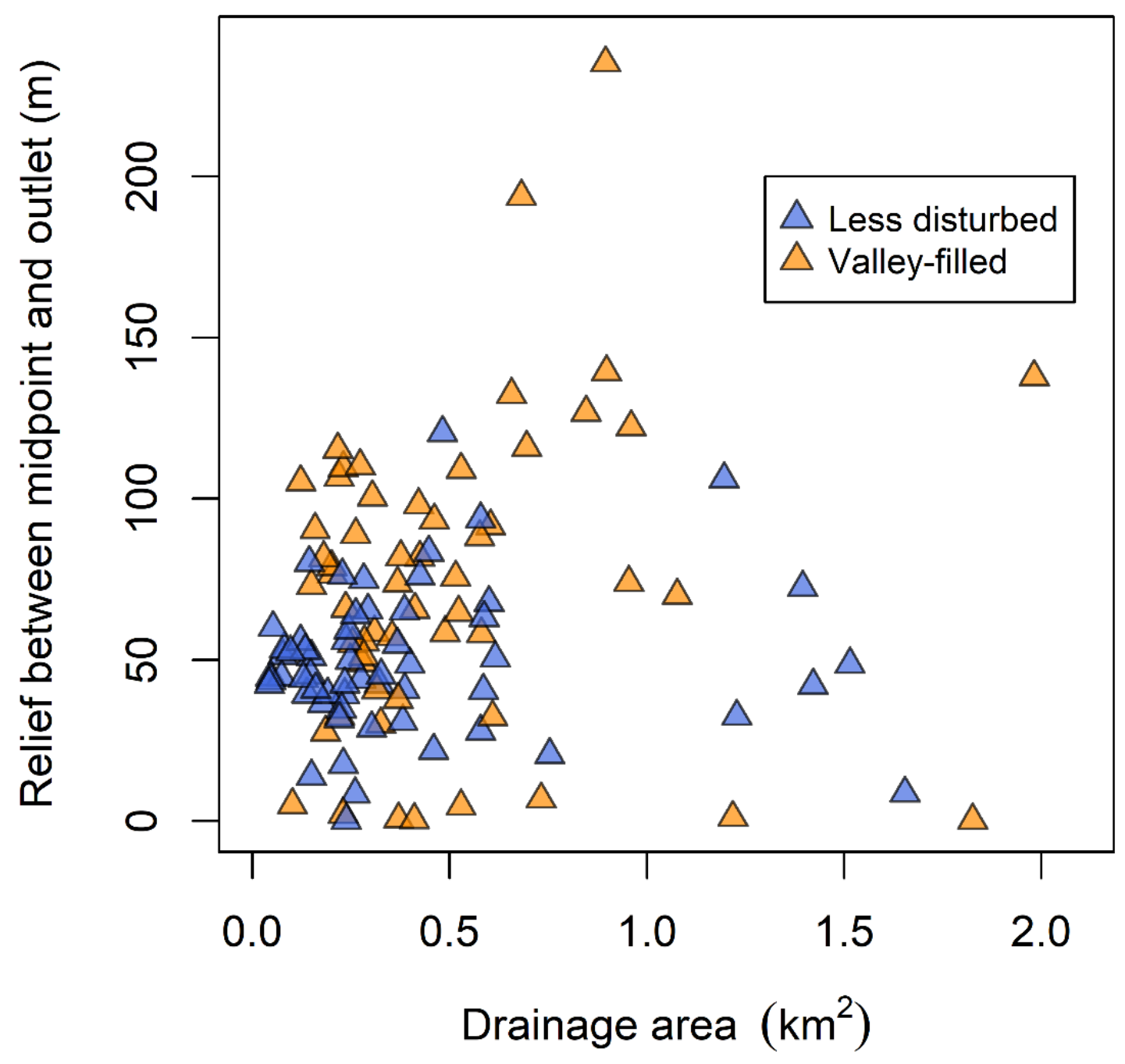

Figure 81. Plot of drainage area and catchment midpoint-outlet relief for less disturbed and valleyfilled catchments in both the Holden and Amherstdale datasets. The valley-filled catchments averaged higher relief. 


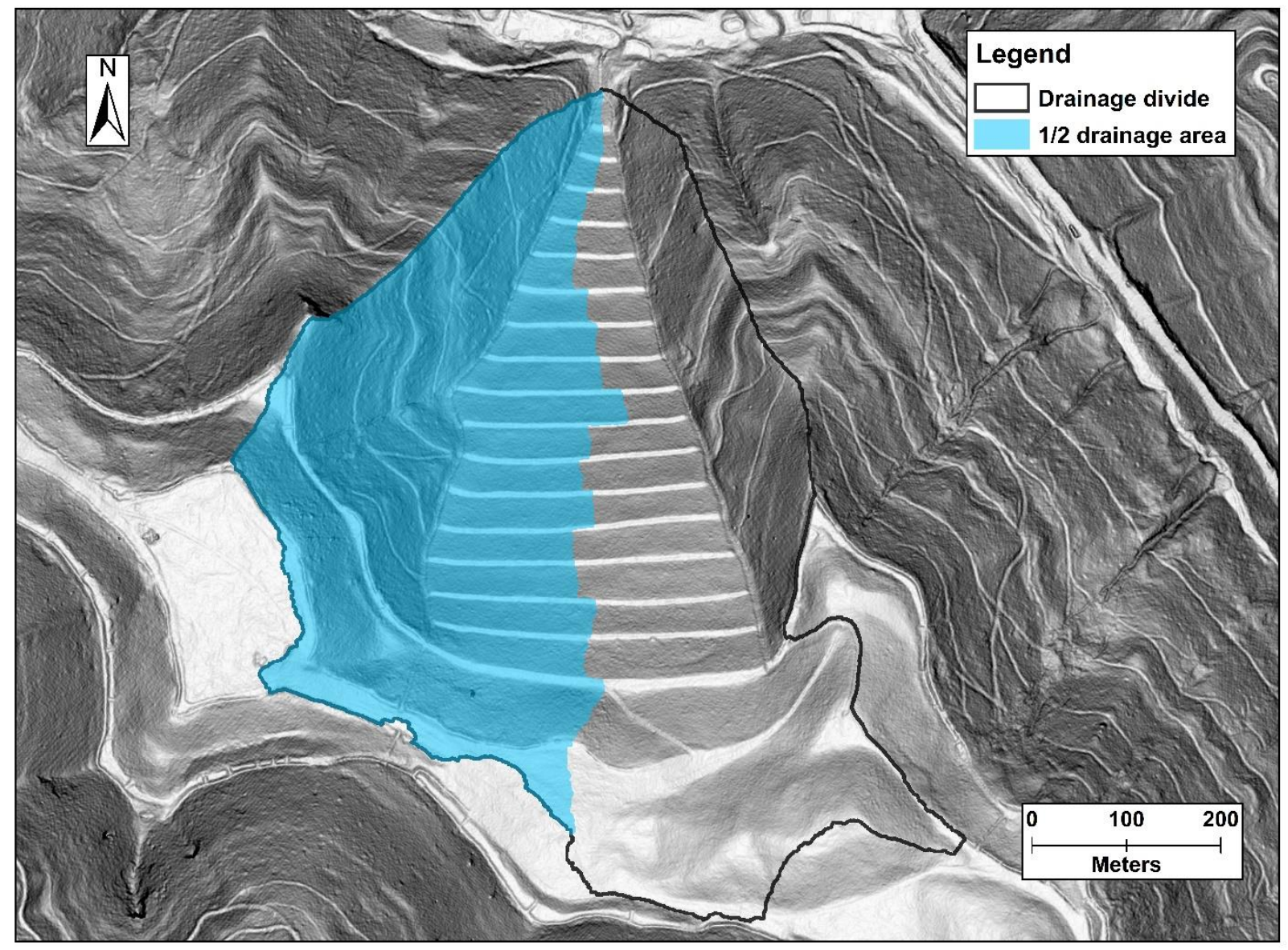

Figure 82. LiDAR-derived slopeshade of valley-filled catchment from the Amherstdale dataset exhibiting a catchment midpoint at the coming together of the two groin drains at the end of the valley fill toe. This condition means that the groin drains should convey the same amount of water. 


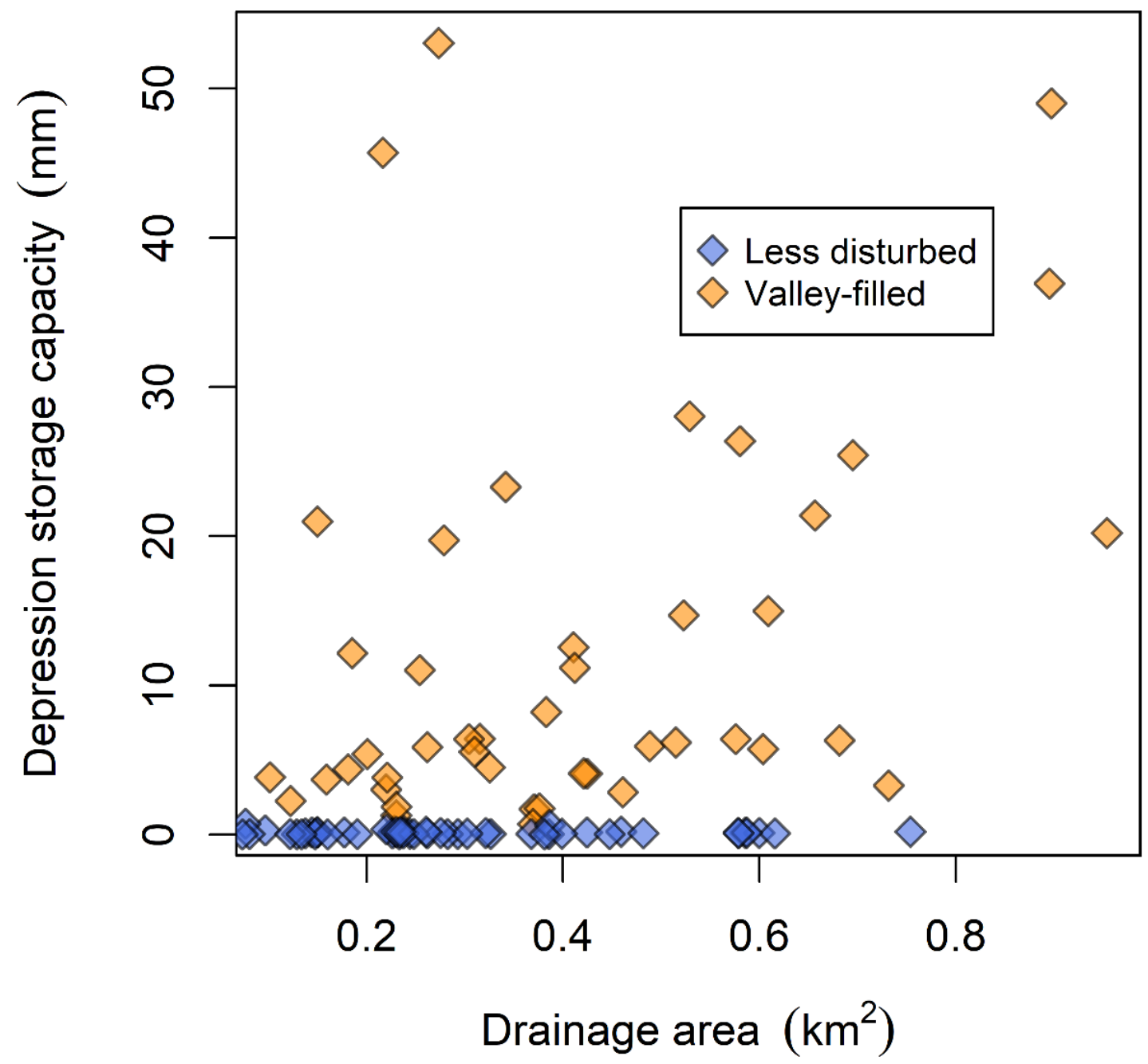

Figure 83. Plot of drainage area and depression storage capacity for valley-filled and less disturbed catchments in the Holden and Amherstdale datasets. Valley-filled catchments averaged much higher due to the presence of retention cells and other depressions. 


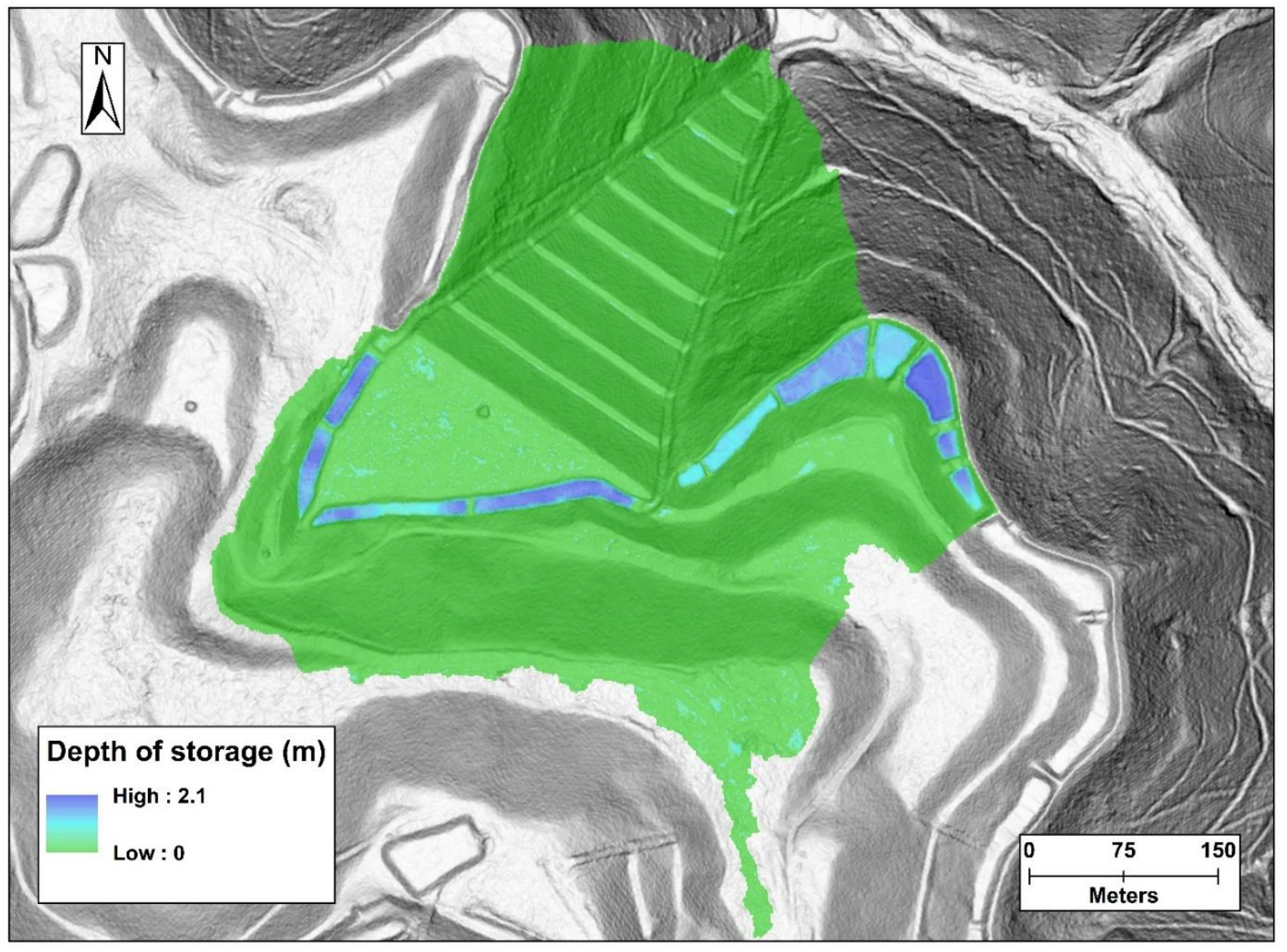

Figure 84. LiDAR-derived depression storage raster draped over slopeshade of a valley-filled catchment from the Amherstdale dataset. Depression storage capacity is accumulated in the retention cells of this catchment with minor contributions from the crown and terraces of the valley fill. 


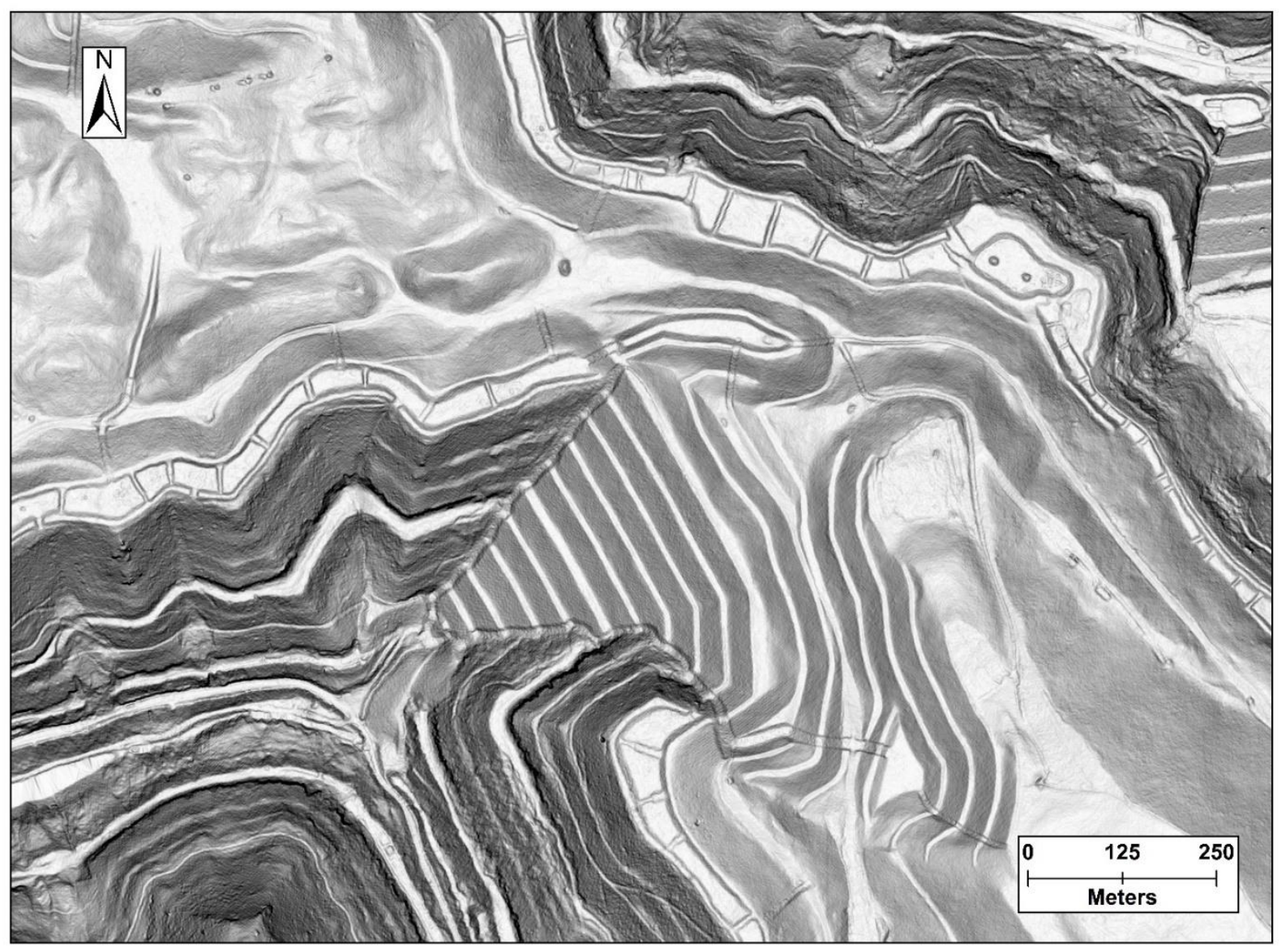

Figure 85. LiDAR-derived slopeshade of the large and abundant retention cell structures present upon the MTR/VF landscape of the Amherstdale dataset. Construction methods seemingly caused the depression storage capacity of these valley-filled catchments to average higher than those of the Holden dataset. 


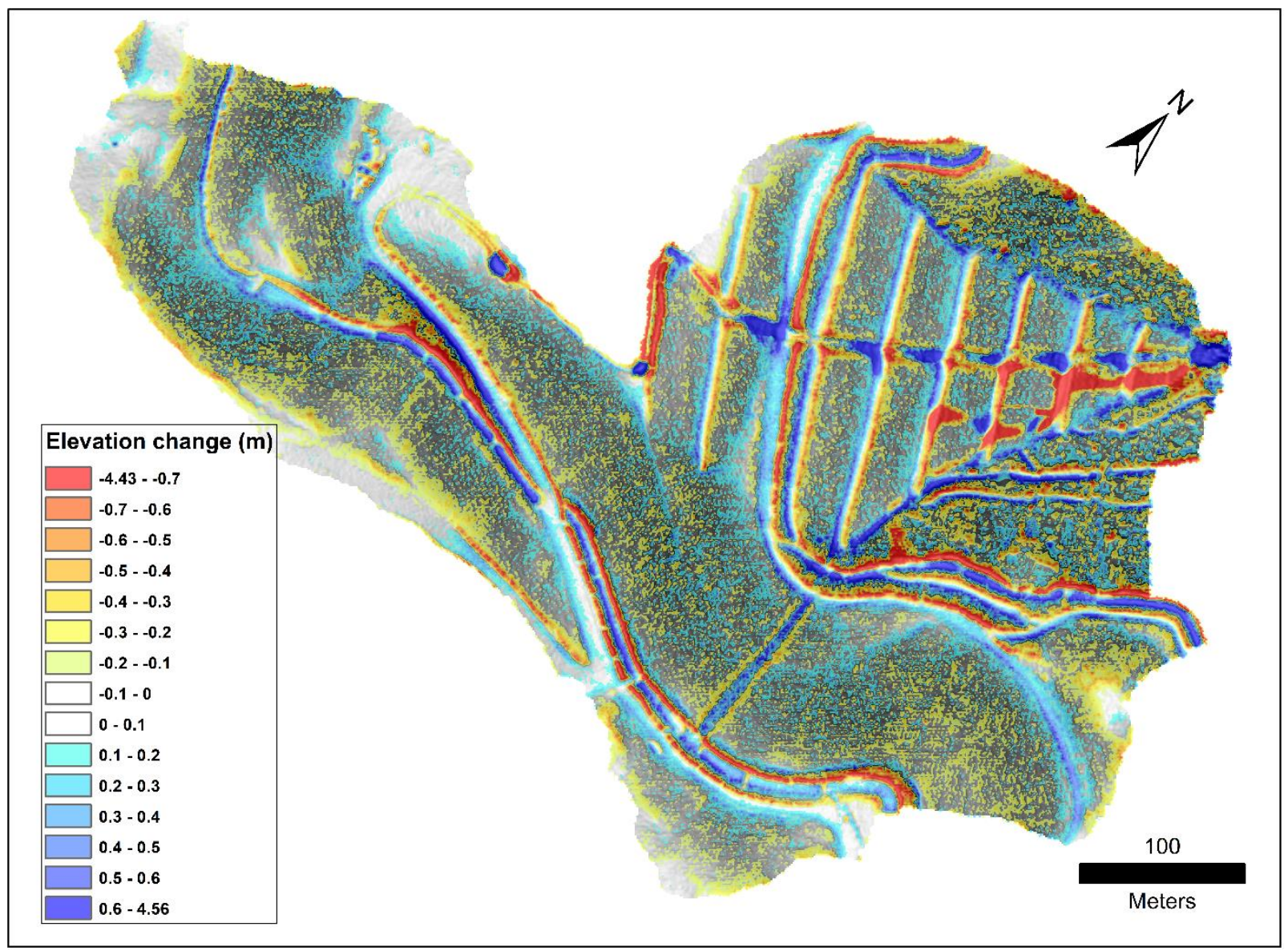

Figure 86. DEM of difference (DoD) for the Whitman \#20 reference run showing elevation change between the initial topography and a 1000-year modeling run using the CAESAR-Lisflood landscape evolution model. A large gully incised the toe of the valley fill and extended up to the $4^{\text {th }}$ terrace up from the outlet. The gully was induced by the overtopping of a retention cell above the southeast colluvial sideslope, which caused erosion on both the sideslope and the valley fill face. The DoD also shows that small alluvial fans developed in the constructed drain where the drain flattened along terrace flats. Retention cells were filled up to $1.5 \mathrm{~m}$. 


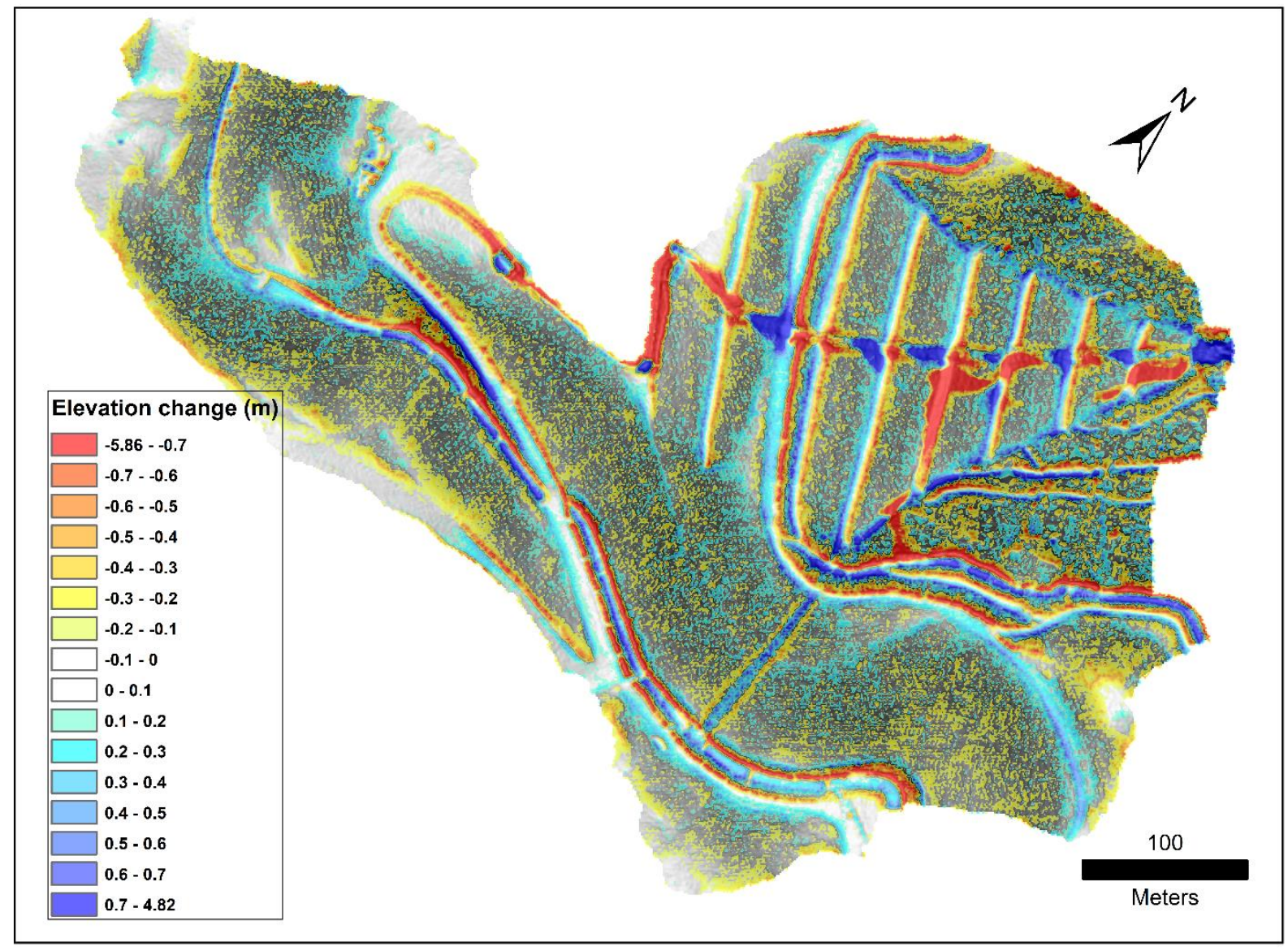

Figure 87. DoD of finer grain size distribution run for Whitman \#20 catchment. Gully erosion was more intense (higher max depth of $5.86 \mathrm{~m}$ ) and occurred closer to constructed drain relative to the reference model run. 


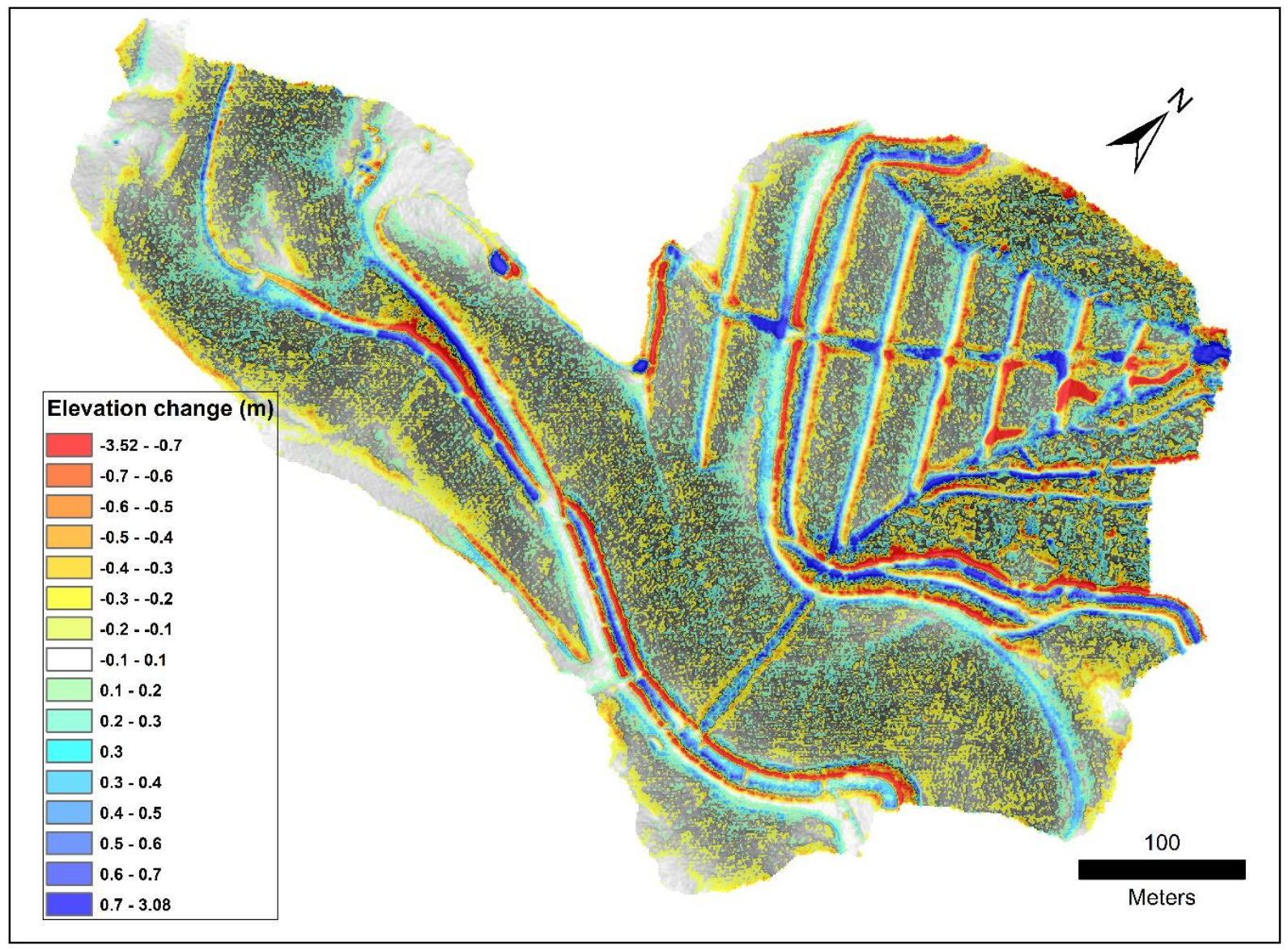

Figure 88. DoD of the coarser grain size distribution run for Whitman \#20 catchment. Gully erosion was less intense and occurred closer to the southeast colluvial sideslope relative to the reference model run. The alluvial fans that developed within the constructed drain were small compared to the reference run. 


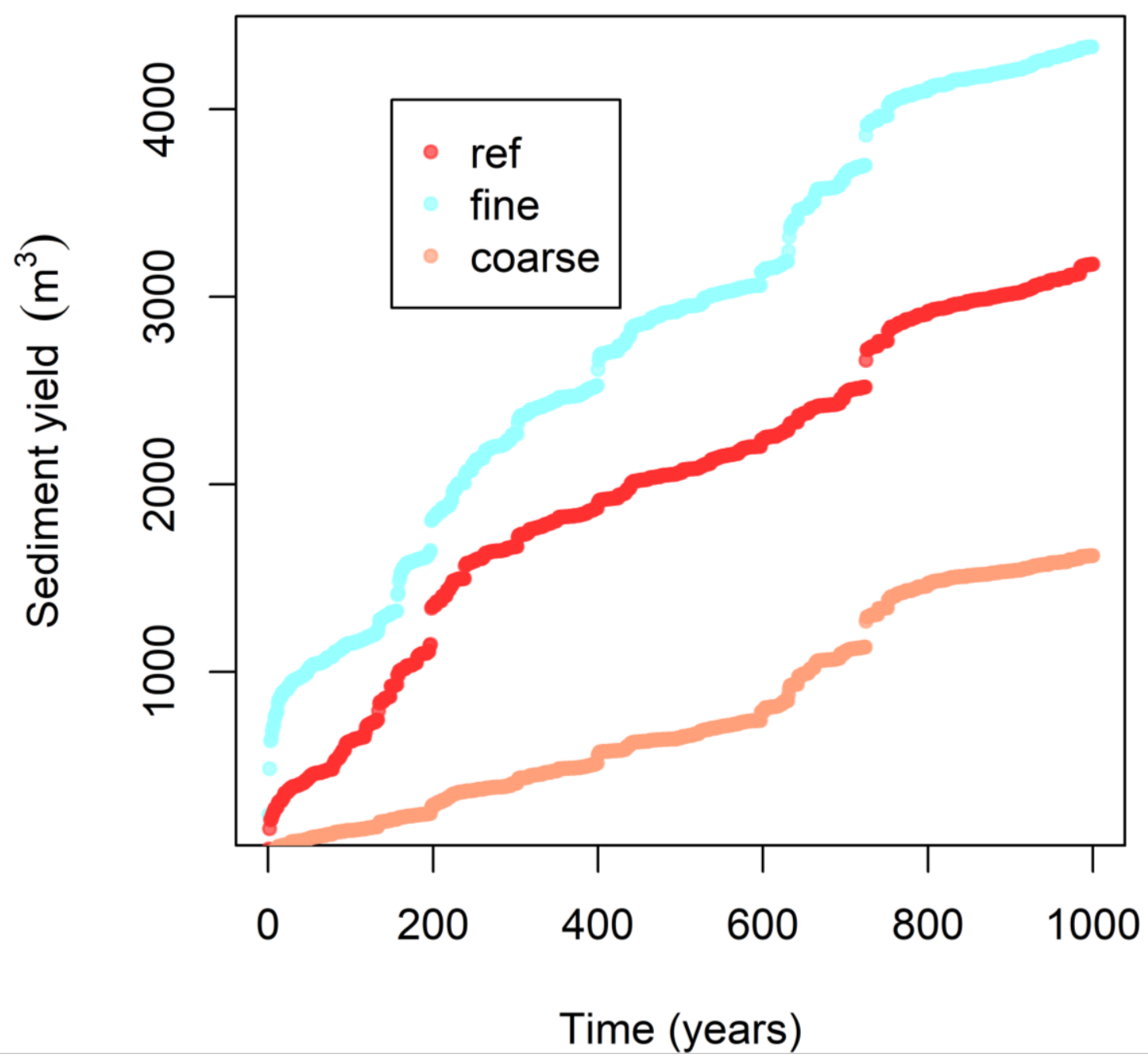

Figure 89. Cumulative yearly sediment yield for all model runs for the Whitman \#20 catchment. The gaps are indicative of years with large sediment yield. 


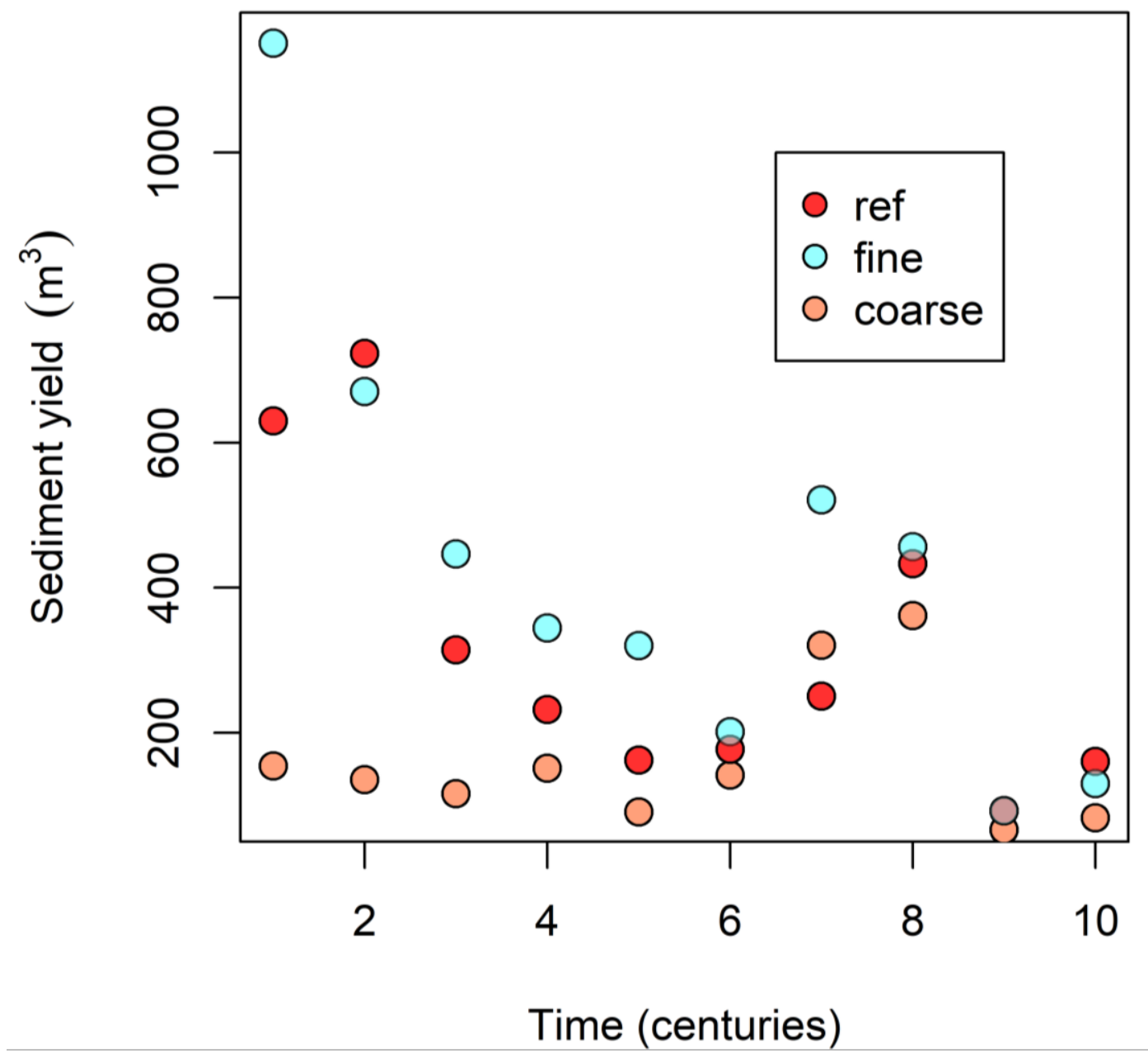

Figure 90. Centennial sediment yield (sediment exported from the catchment every 100 years) from all three model runs for Whitman \#20. The brown point at the 900-year mark is the ref and fine points at very similar values on the $y$-axis. It is difficult to determine if centennial sediment yield will continue to trend lower. 


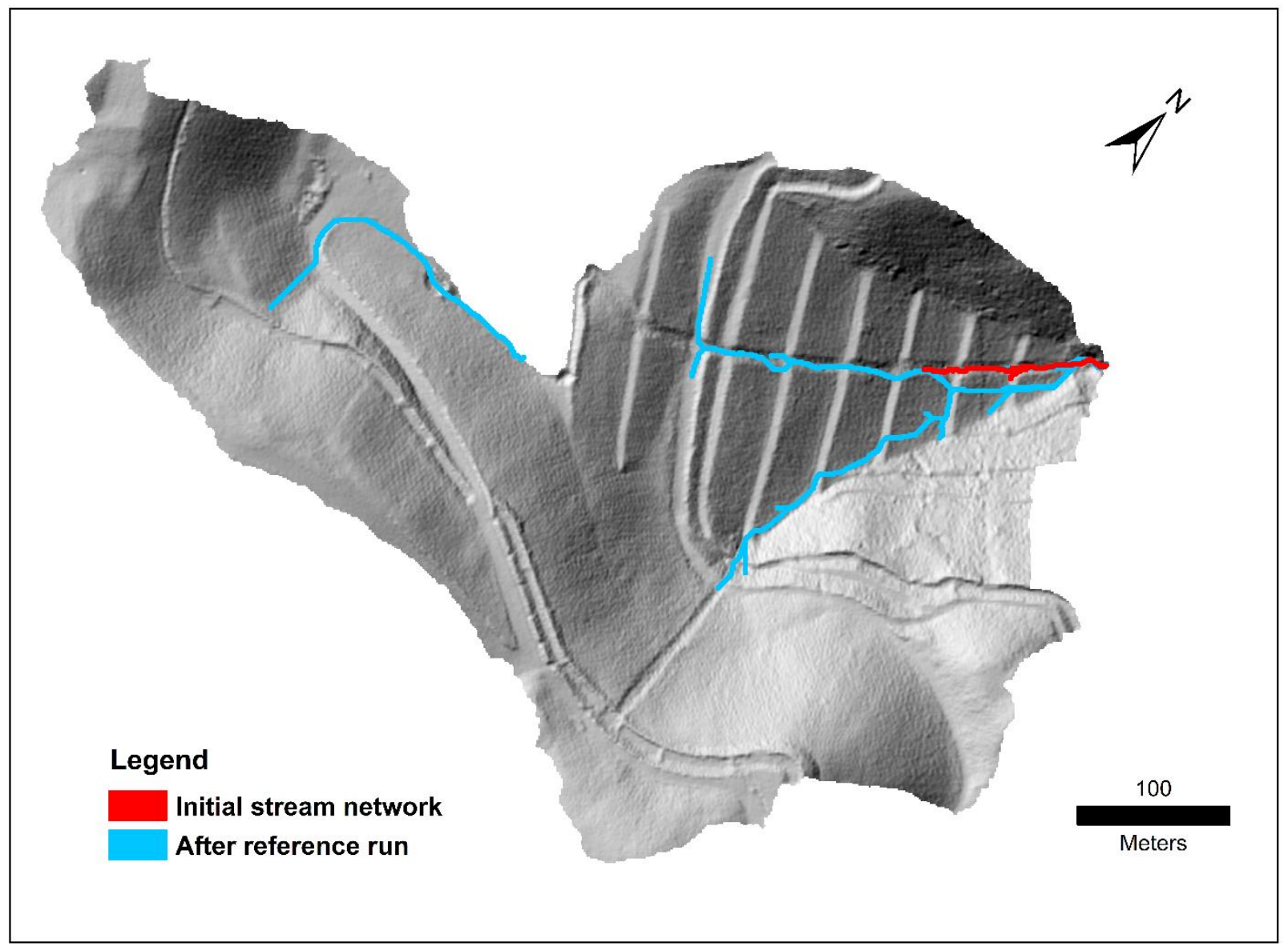

Figure 91. Extracted stream networks before and after 1000 years of landscape evolution modeling overlaid on a hillshade of the initial topography of Whitman \#20. The reference run on Whitman \#20 increased drainage density from $0.67 \mathrm{~km}^{-1}$ to $4.42 \mathrm{~km}^{-1}$. The upper discontinuous channel may be due to the different flow routing codes within CAESAR-Lisflood and the stream channel extraction algorithm. 


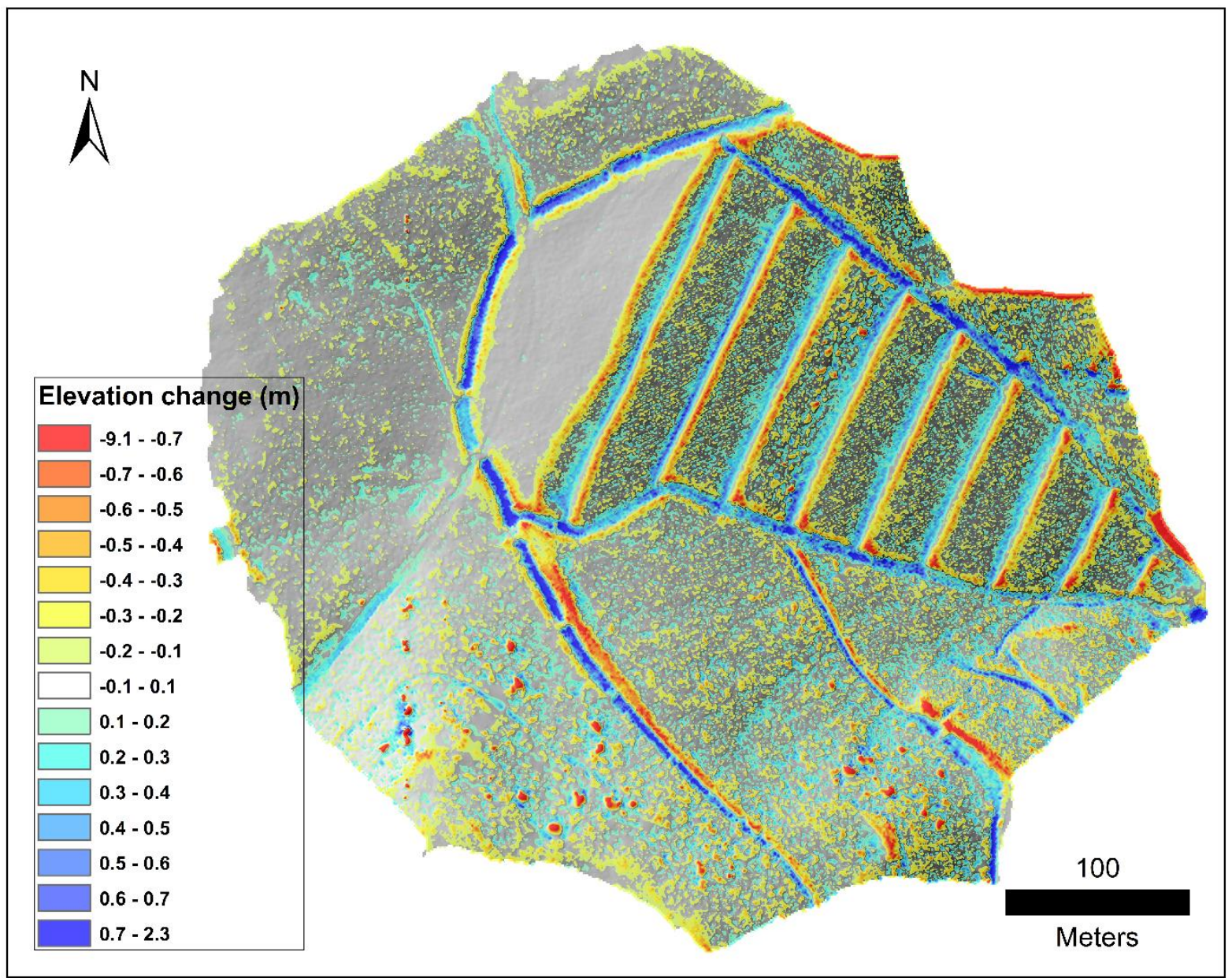

Figure 92. DoD from reference run for the Whitman \#8 catchment. The upper reaches of the groin drains and retention cells were zones of deposition. The north colluvial sideslope near the toe was undermined by a stream channel that was diverted from the groin drain due to aggradation within it. 

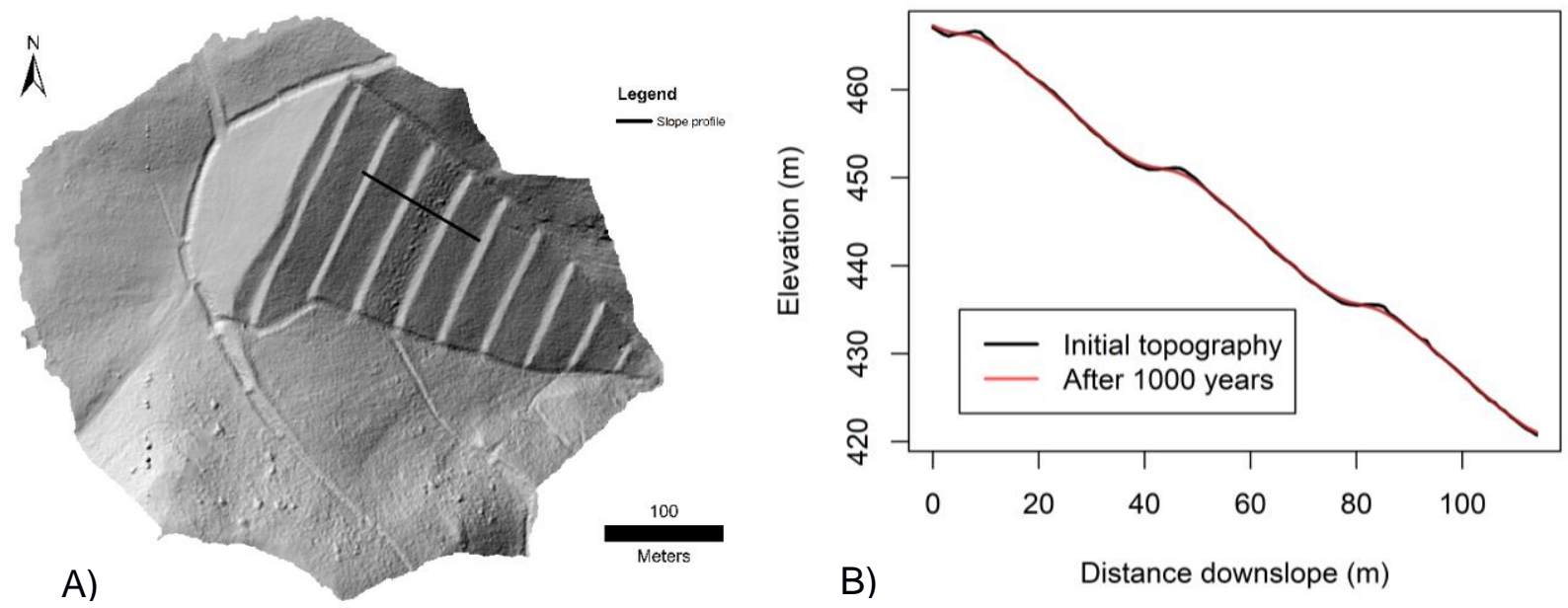

Figure 93. A) LiDAR-derived hillshade of Whitman \#8 showing of slope profile plotted in B. B) Plot of slope profile showing the rounding of sharp terrace edges by soil creep. 


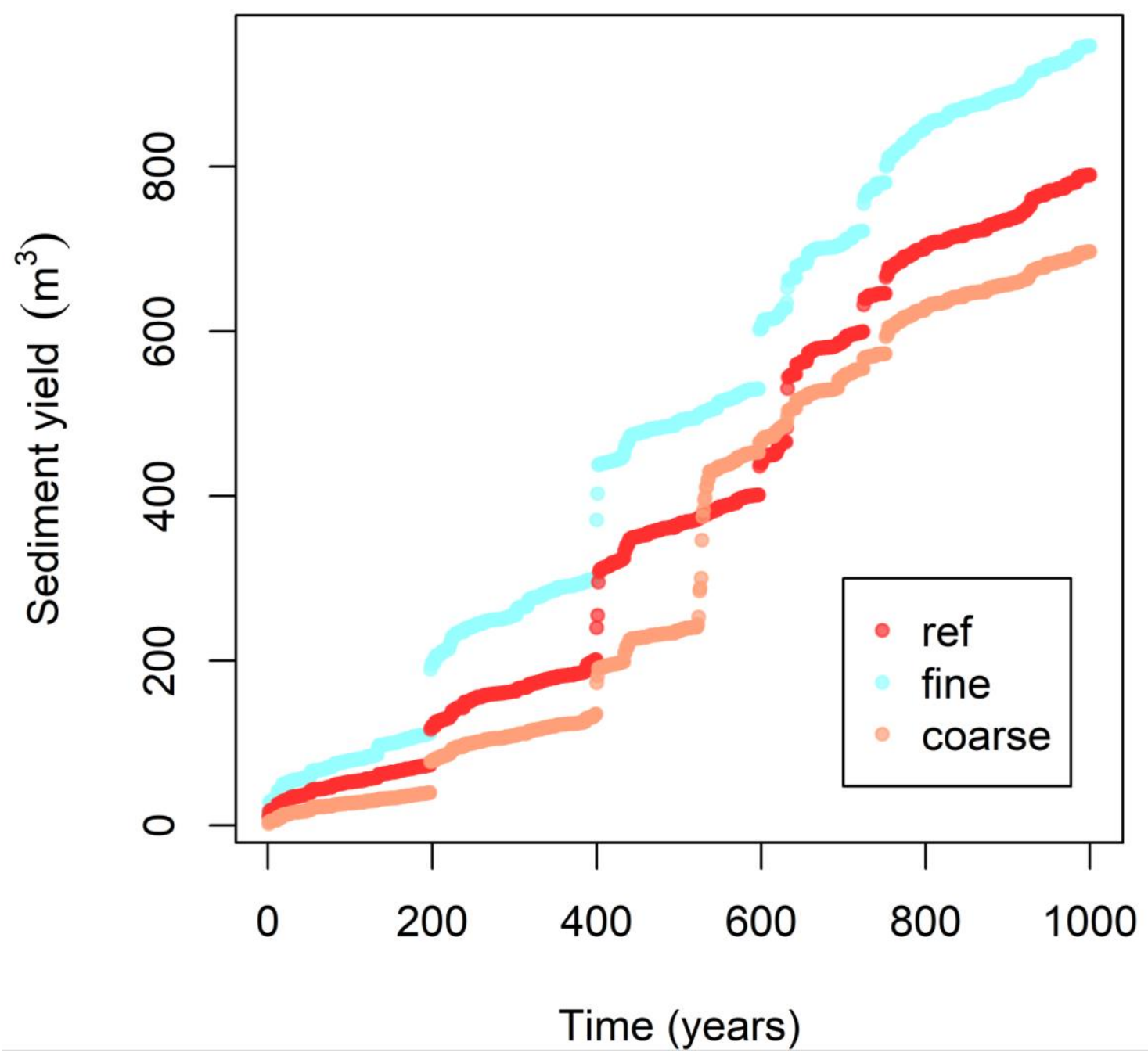

Figure 94. Cumulative yearly sediment yield from Whitman \#8 for all three model runs. Yields were more similar among the model runs compared to those of Whitman \#20. 


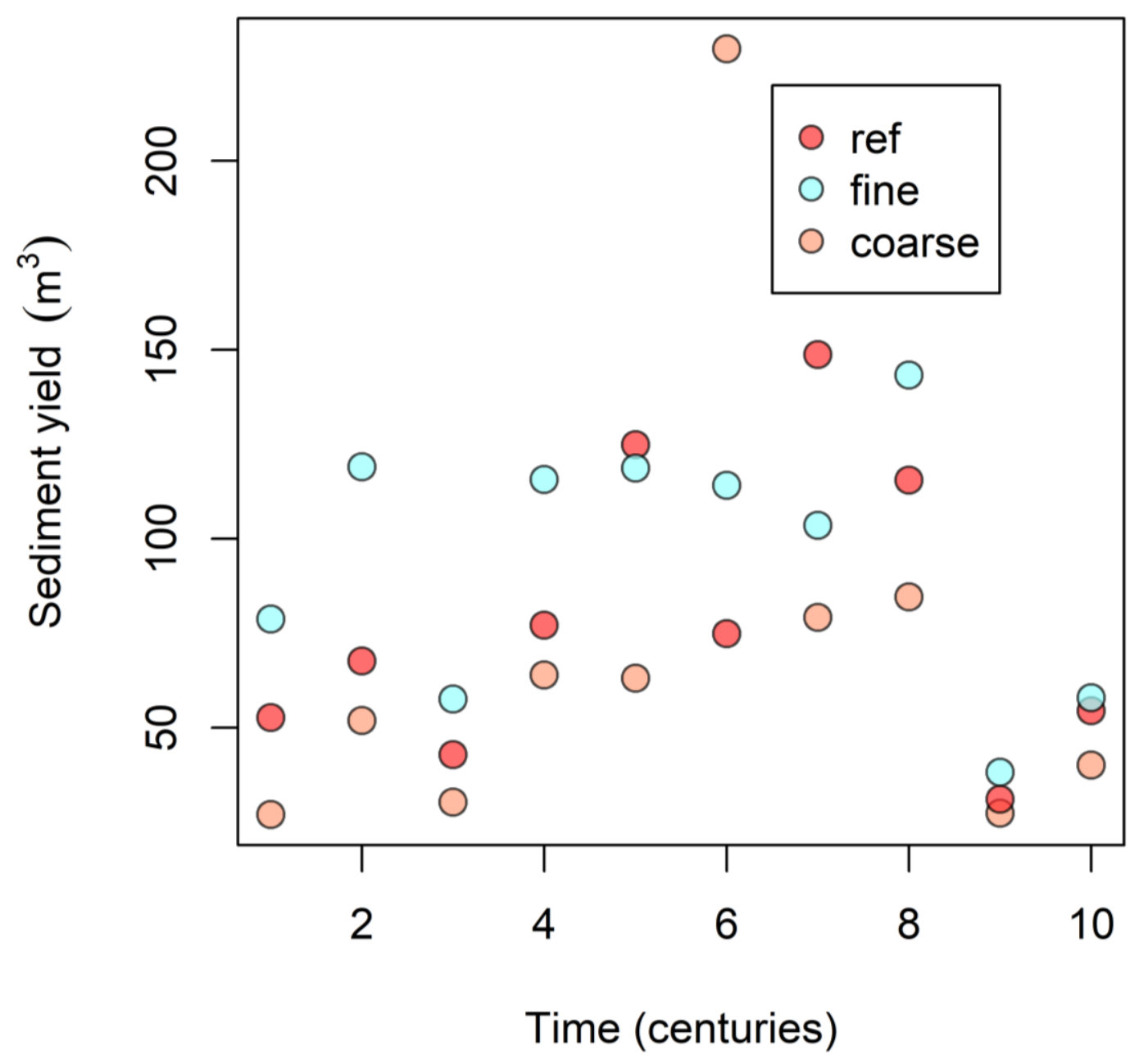

Figure 95. Centennial sediment yield from Whitman \#8 for all model runs. The largest centennial yield was observed in the coarser run from 500-600 years due to the undermining of the a colluvial sideslope in the $528^{\text {th }}$ year. This same process occurred just before the $400^{\text {th }}$ year in the other model runs, which split the resulting sediment export between two centuries. 


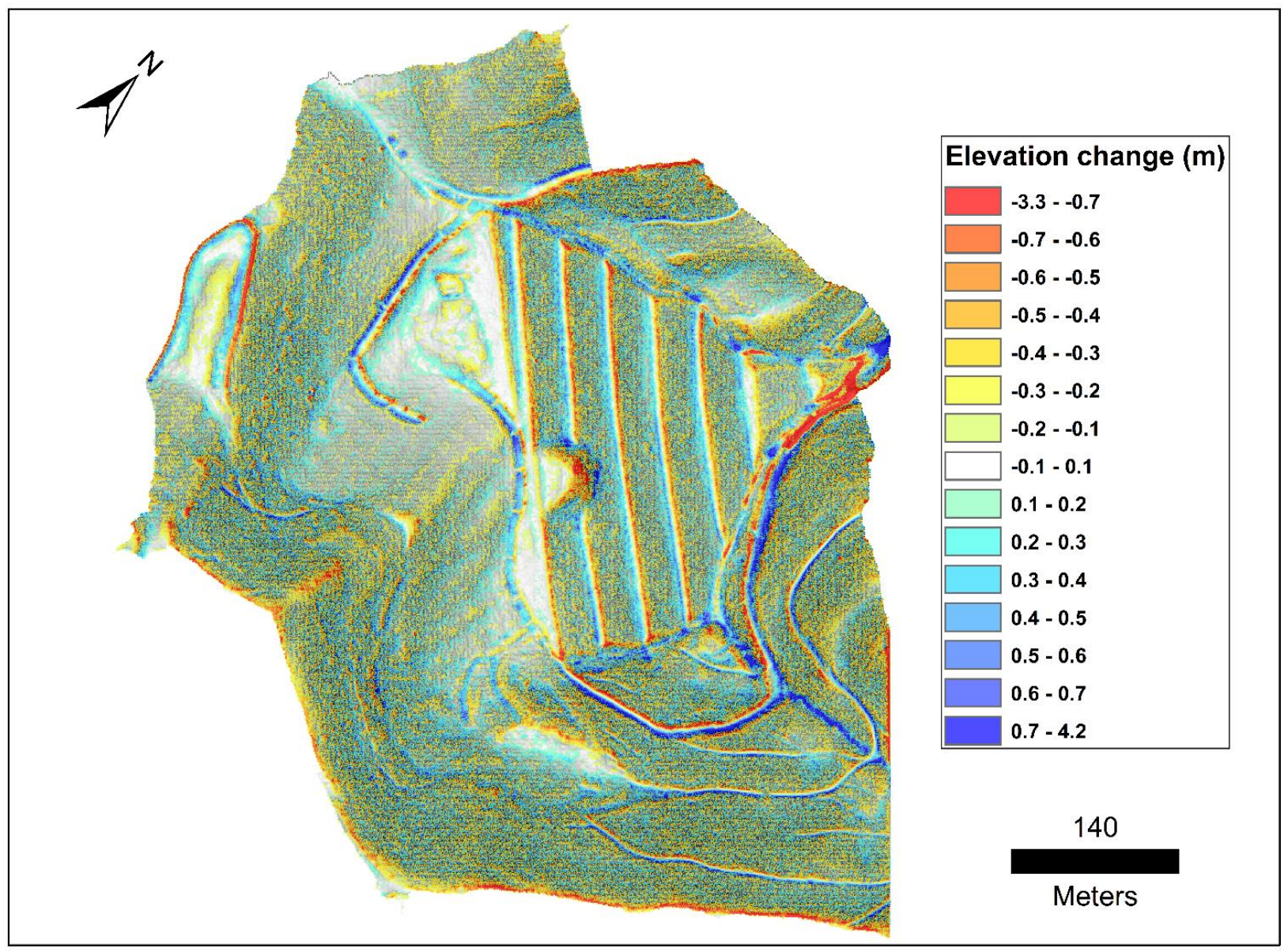

Figure 96. DoD between initial topography and after 1000 years of the reference grain size distribution run upon the Whitman \#18 catchment. The toe of the valley fill experienced the most erosion. The groin drain was overtopped, which caused erosion into a nearby road. Flow from the road came back upon the toe of the valley fill and eroded a $\sim 3$ m deep gully. 


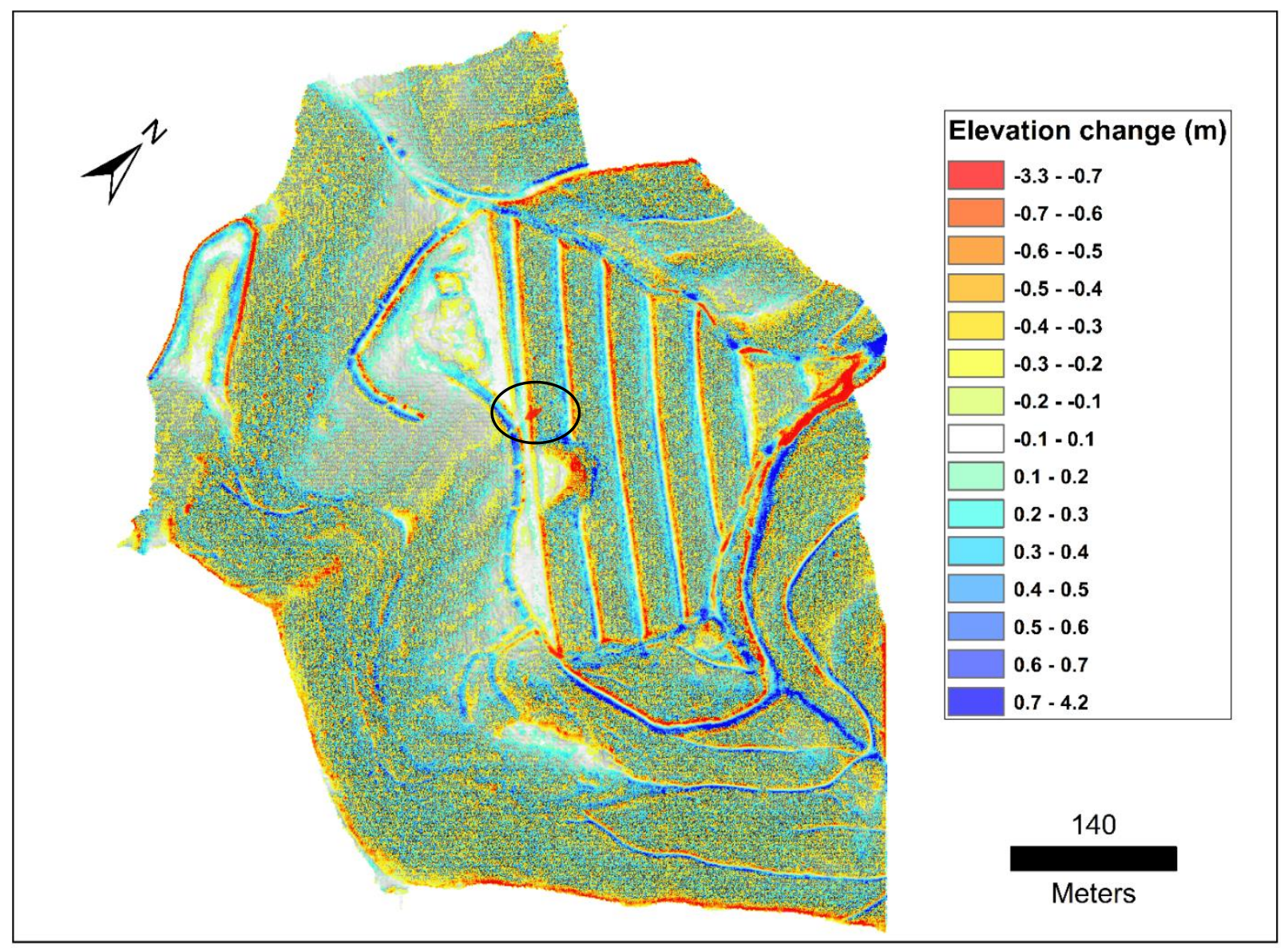

Figure 97. DoD between initial topography and after 1000 years of the fine grain size distribution run upon the Whitman \#18 catchment. The encircled area shows the gully that formed on the first terraceslope pair by overtopping of the adjacent retention cells. Gullies formed from flow over the edges terraces were observed in the field. 


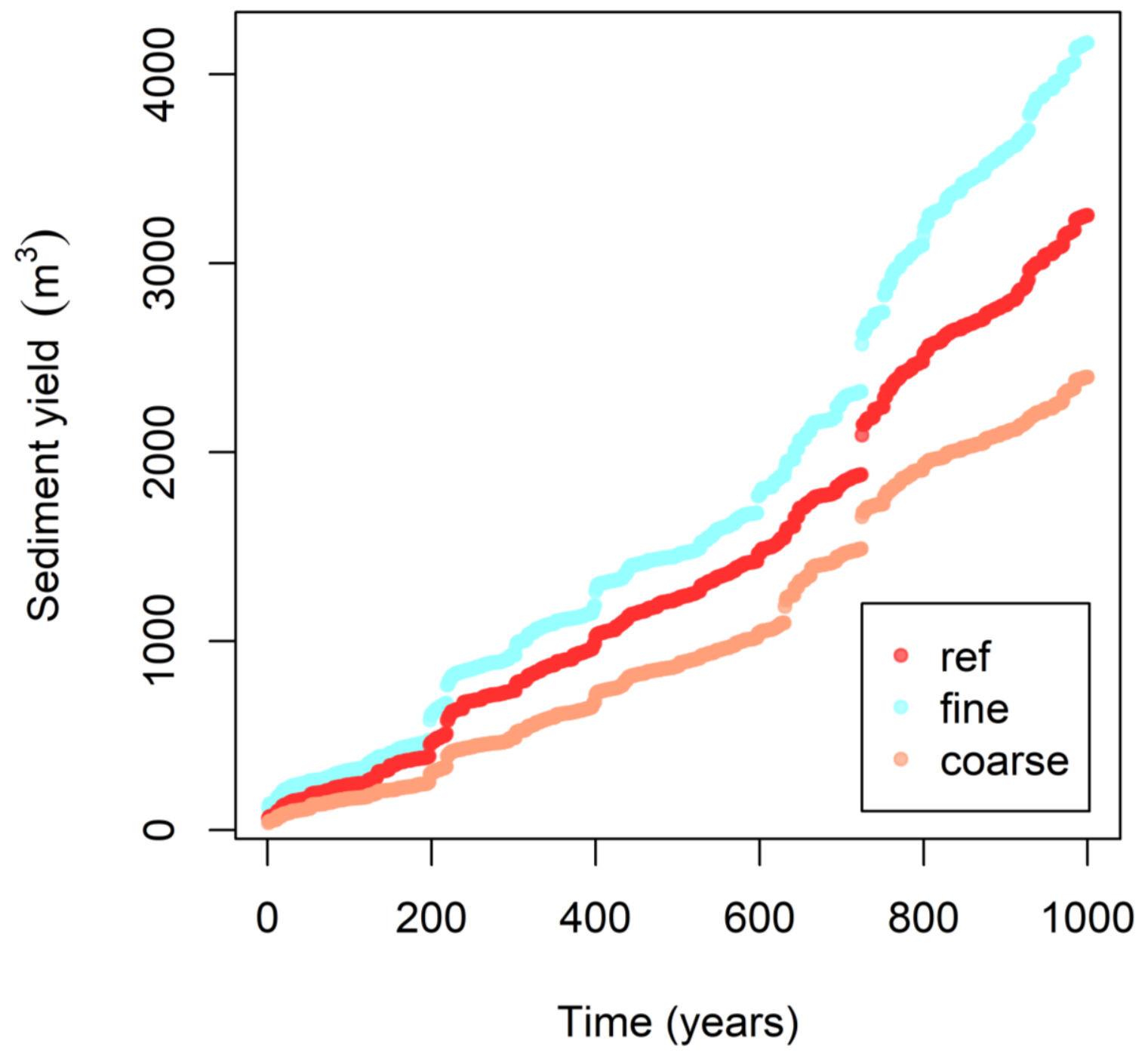

Figure 98. Cumulative yearly sediment yield from the Whitman \#18 catchment for all model runs. All model runs show very similar trends unlike the Whitman \#8 catchment. 


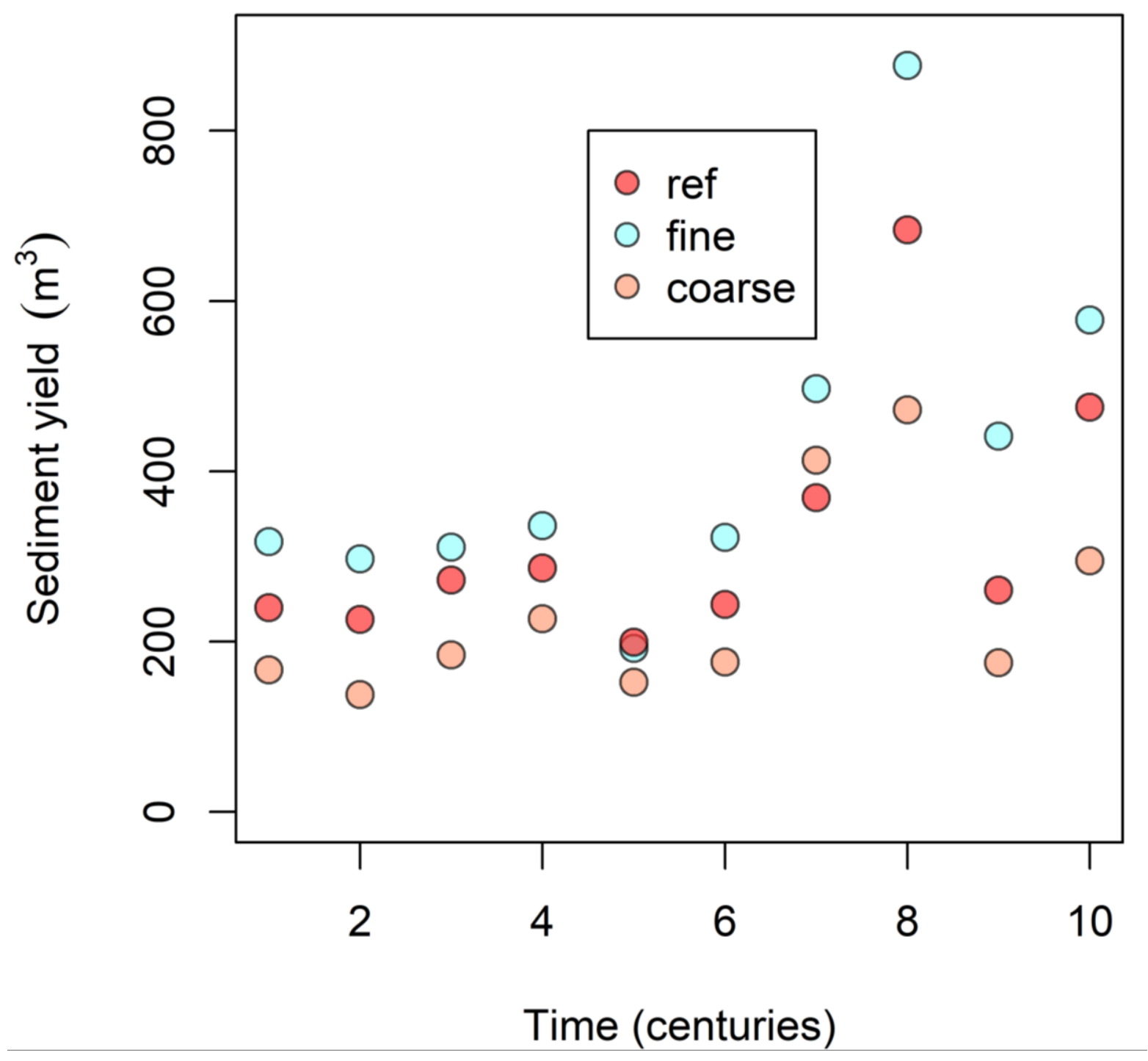

Figure 99. Centennial sediment yield from Whitman \#18 for all model runs. These modeling runs showed that yields can achieve maximum values deep into the 1000-year modeling period. 


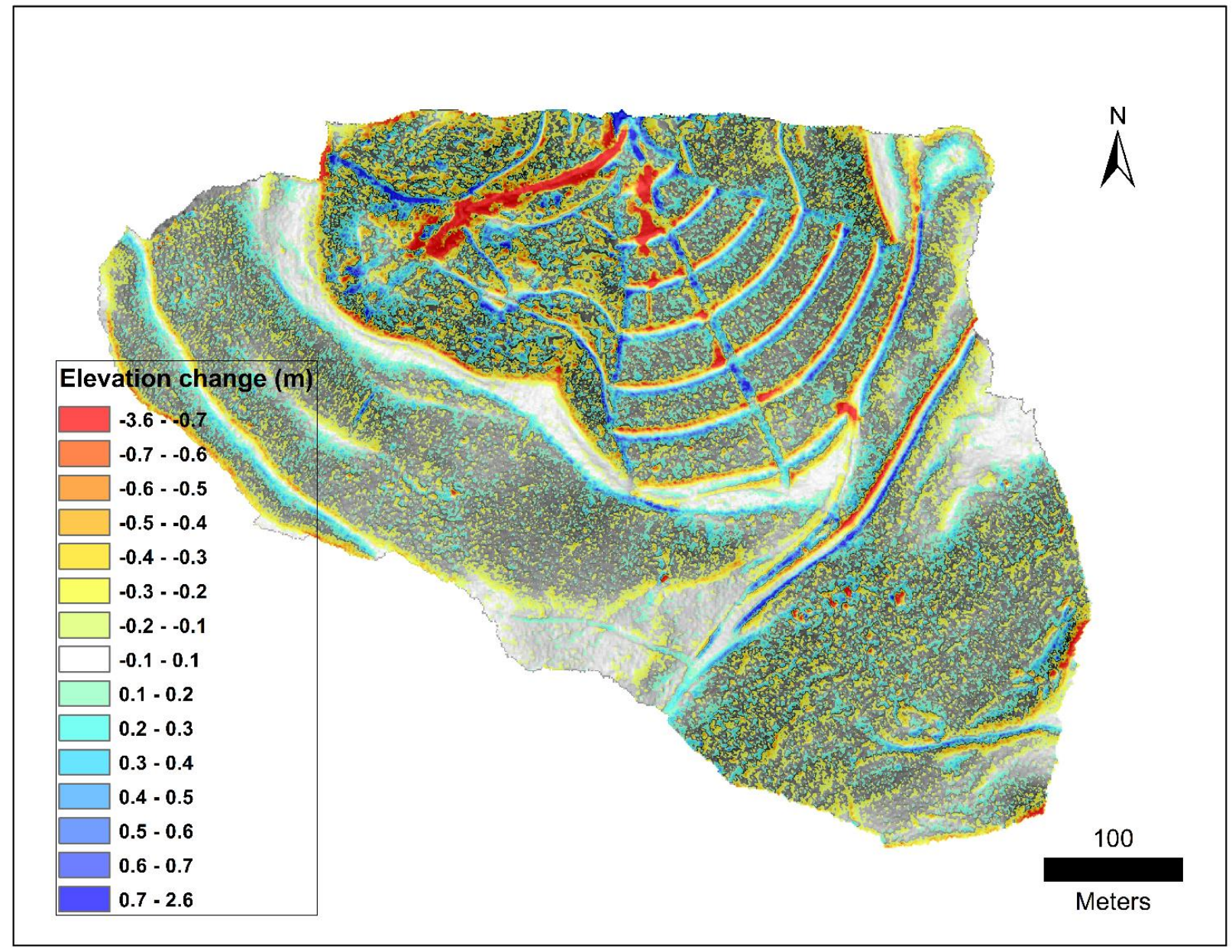

Figure 100. DoD from reference run for Scarlet \#1. The large red area to the left is the incision (to bedrock) of a pre-existing gully on the colluvial sideslope. Gullies formed in near the toe of the valley fill and on the $1^{\text {st }}$ terrace-slope pair. 


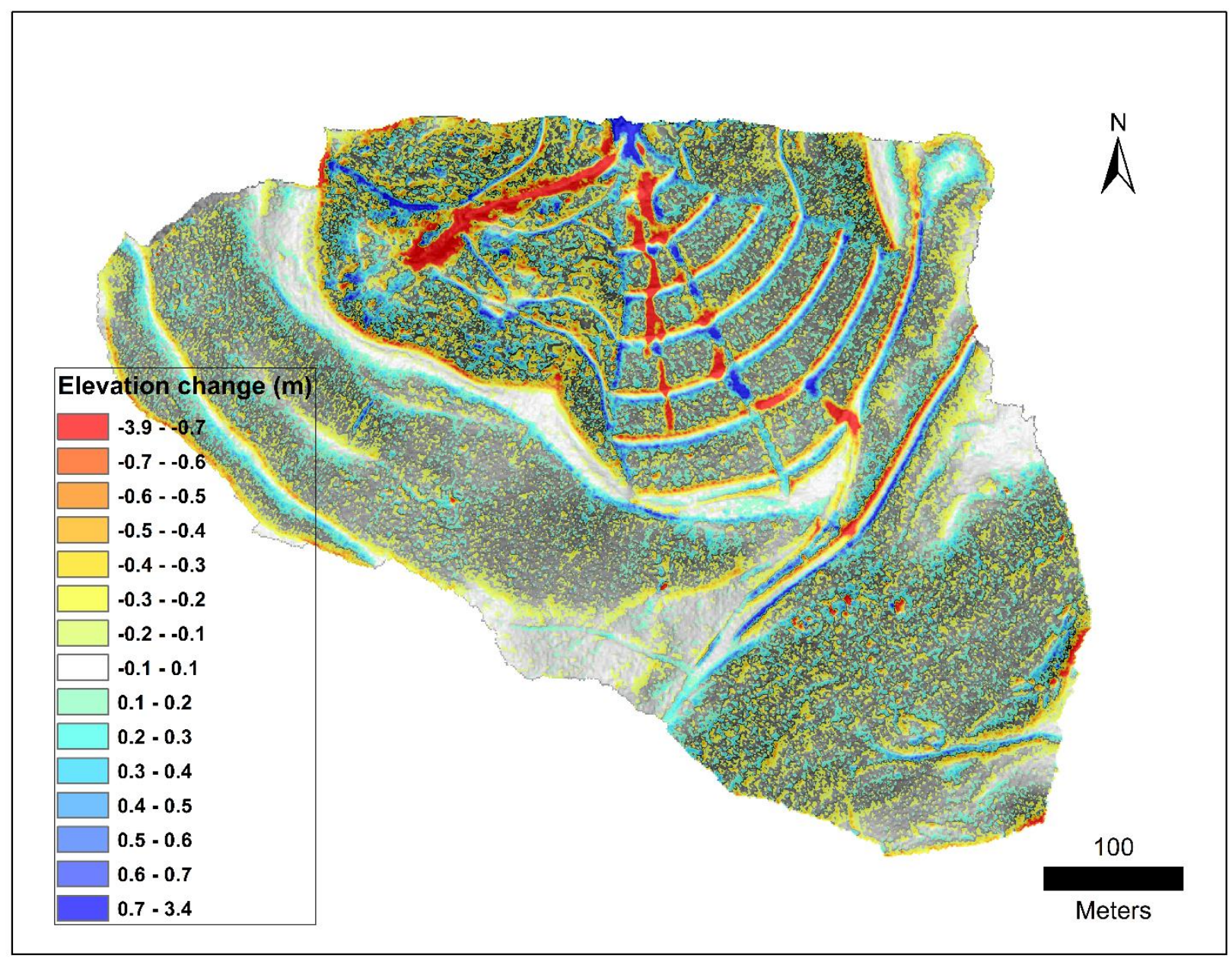

Figure 101. DoD from the finer run for Scarlet \#1. Gully erosion occurred on all terrace-slope pairs of the valley fill face. 


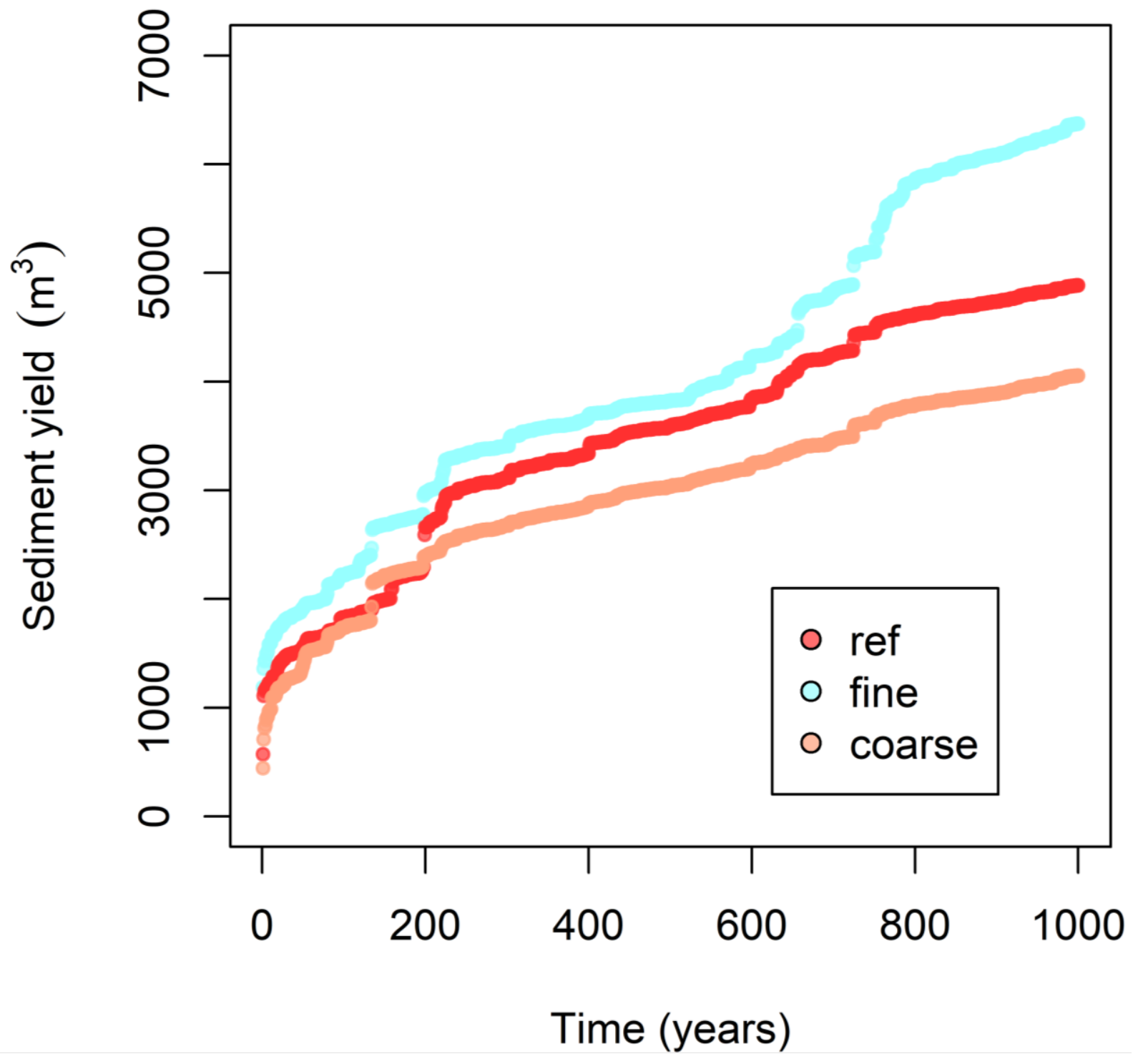

Figure 102. Cumulative yearly sediment yield from Scarlet \#1 for all model runs. The very large sediment yields early were due to gully erosion of a colluvial sideslope. After $\sim 700$ years, the fine run diverges from the other runs due to the more intense erosion of the valley face. 


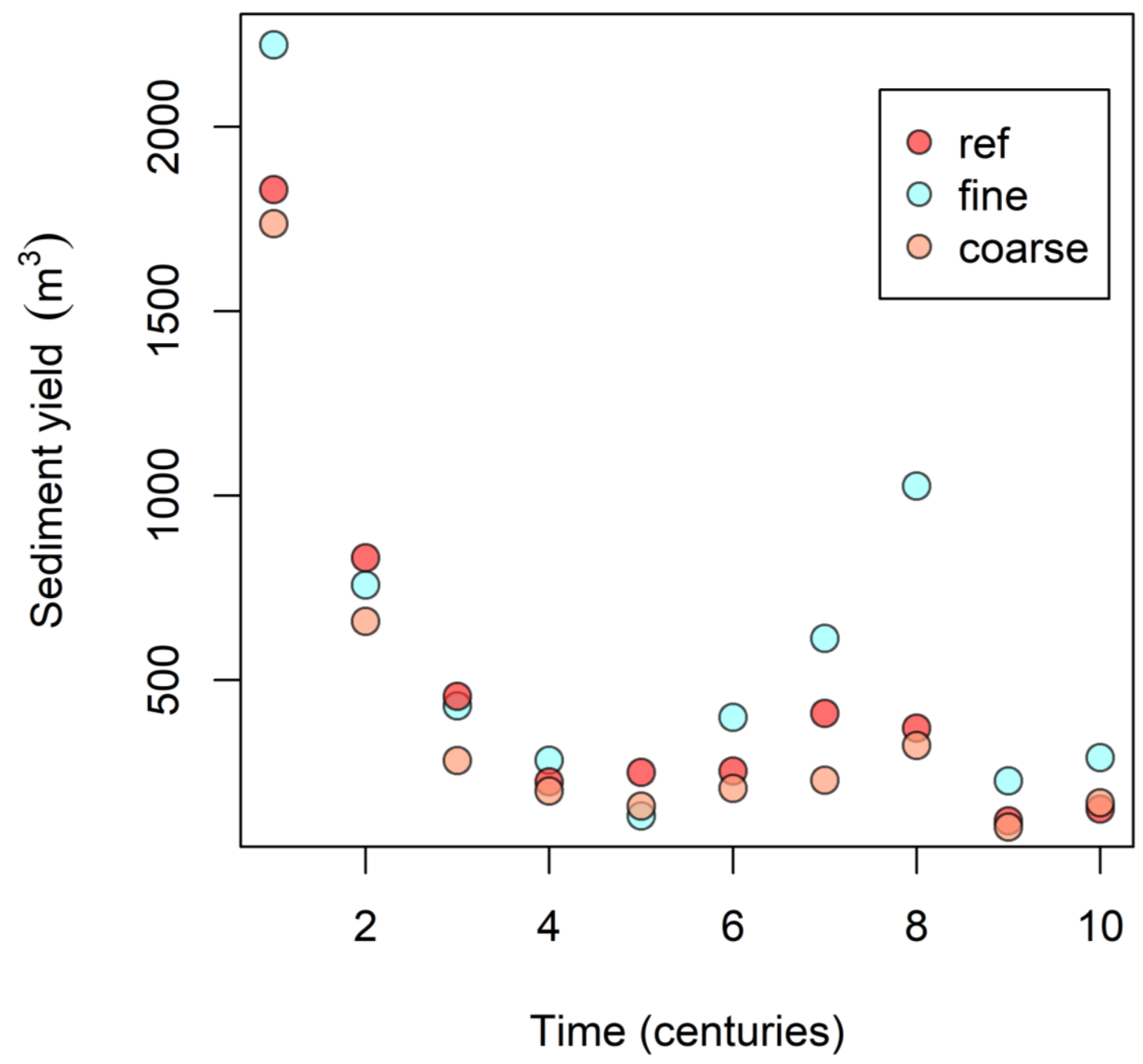

Figure 103. Centennial sediment yields from Scarlet \#1 for all model runs. The finer run shows again that high yields can occur deep into the 1000-year modeling period. 


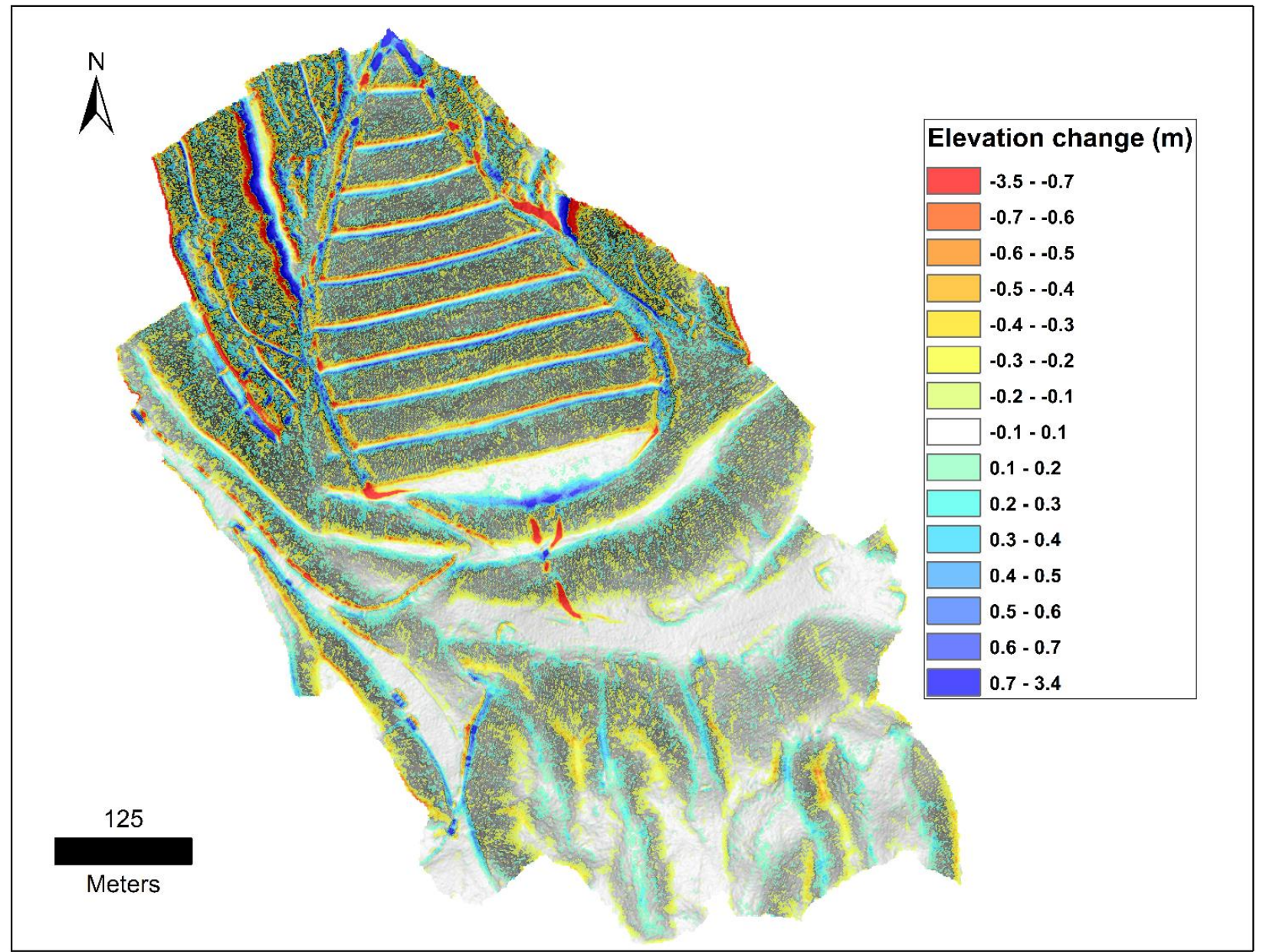

Figure 104. DoD from reference run of the Boone-Kanawha-Raleigh \#1 catchment. The model runs on this catchment uniquely developed gullies in the upper backfill area and above the groin drains. The rightside colluvial sideslope was undermined by flow diverted from an aggraded groin drain. Mass wasting occurred on the steep outcrops on both contour mine roads, which intersect the valley fill face from the side, but the deposits were not remobilized. 


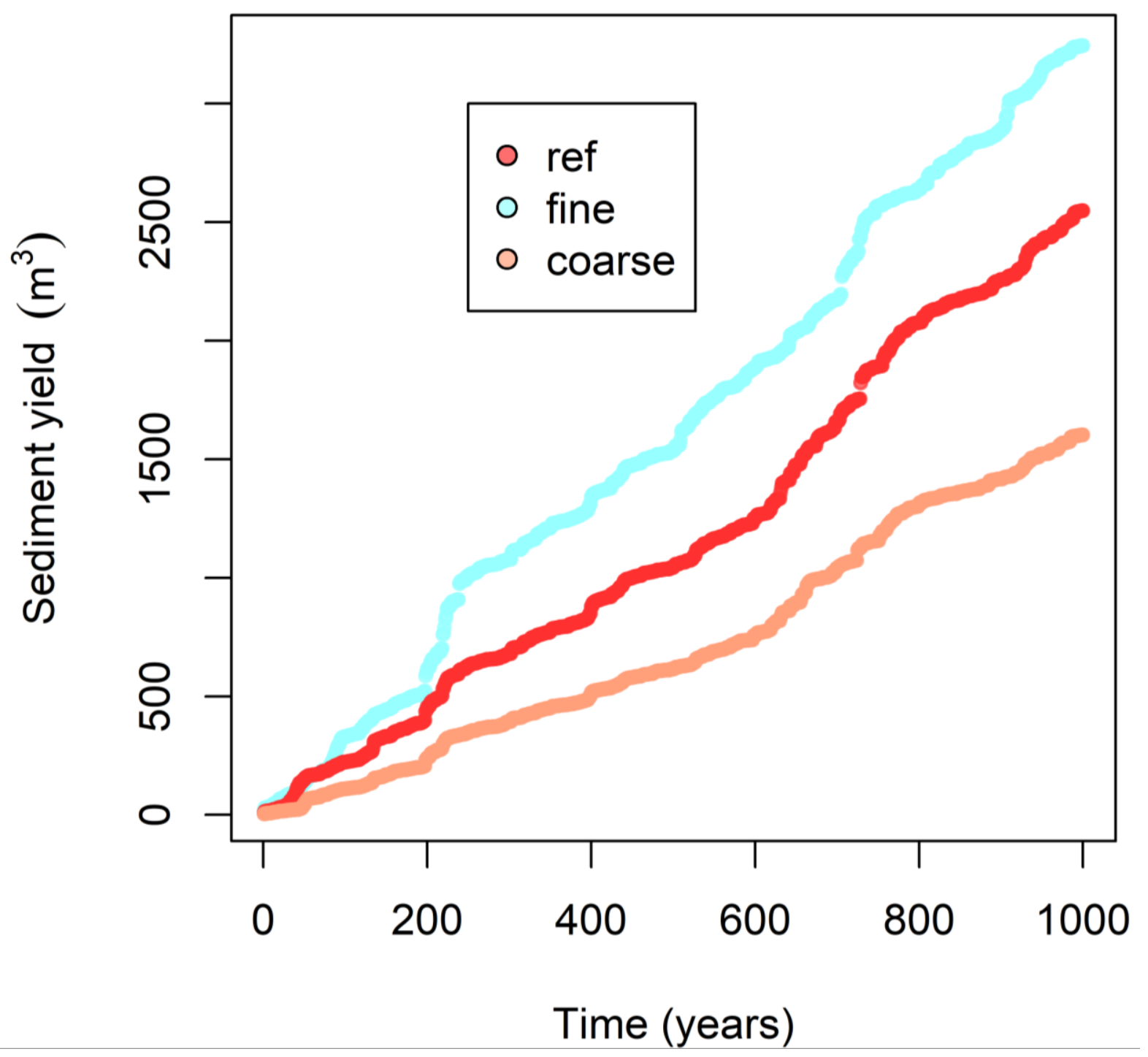

Figure 105. Cumulative yearly sediment yield from Boone-Kanawha-Raleigh \#1 for all model runs. The trends in yield are similar while being different in magnitude. 


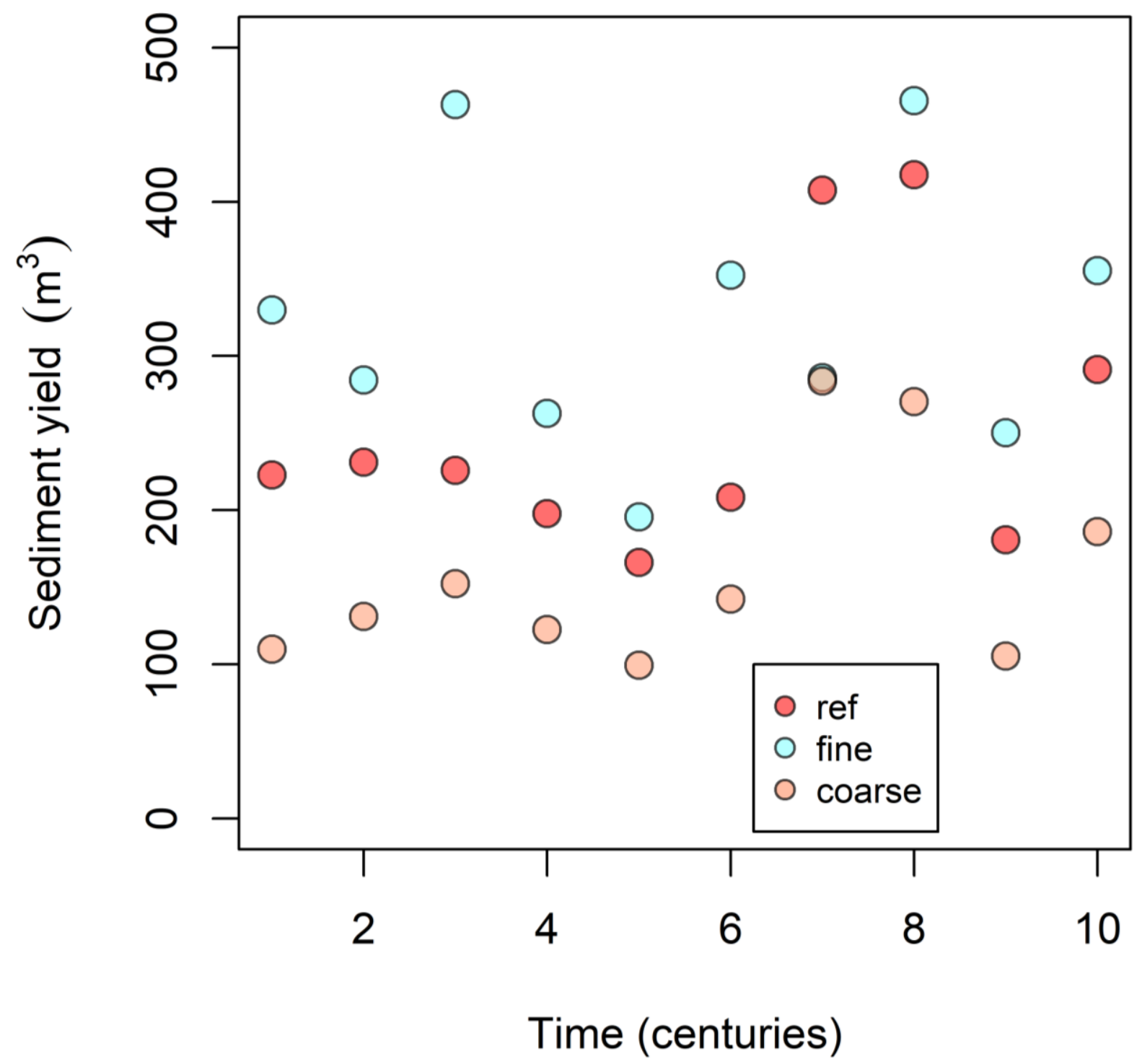

Figure 106. Centennial sediment yields from Boone-Kanawha-Raleigh \#1. This catchment shows that centennial yields can reach maximum values far beyond the initial 100 years of model run time. 


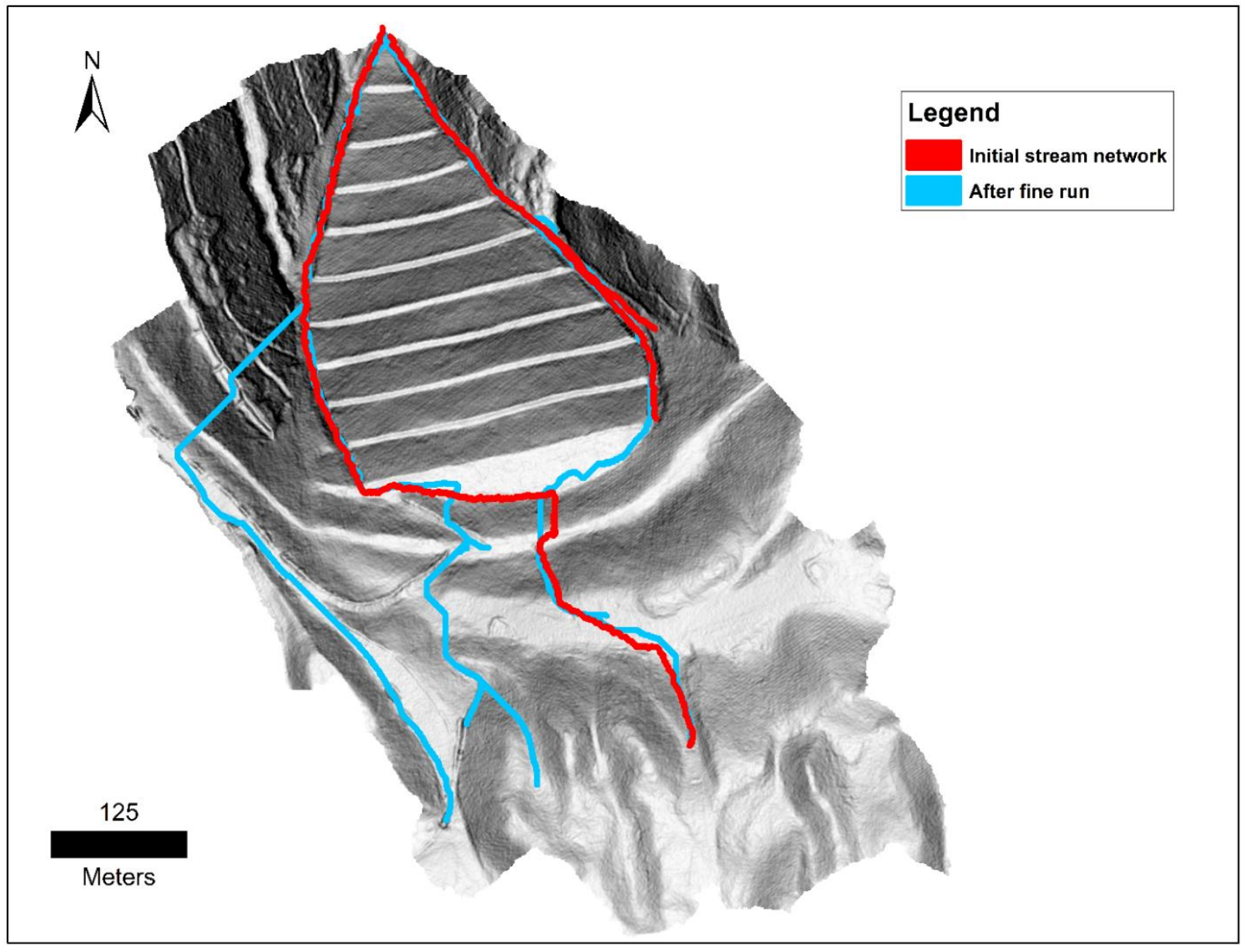

Figure 107. LiDAR-derived slopeshade with stream networks extracted from Boone-Kanawha-Raleigh \#1 before and after the finer grain size distribution model run. Drainage density increased from $4.24 \mathrm{~km}^{-1}$ to $6.10 \mathrm{~km}^{-1}$ in the finer run. 


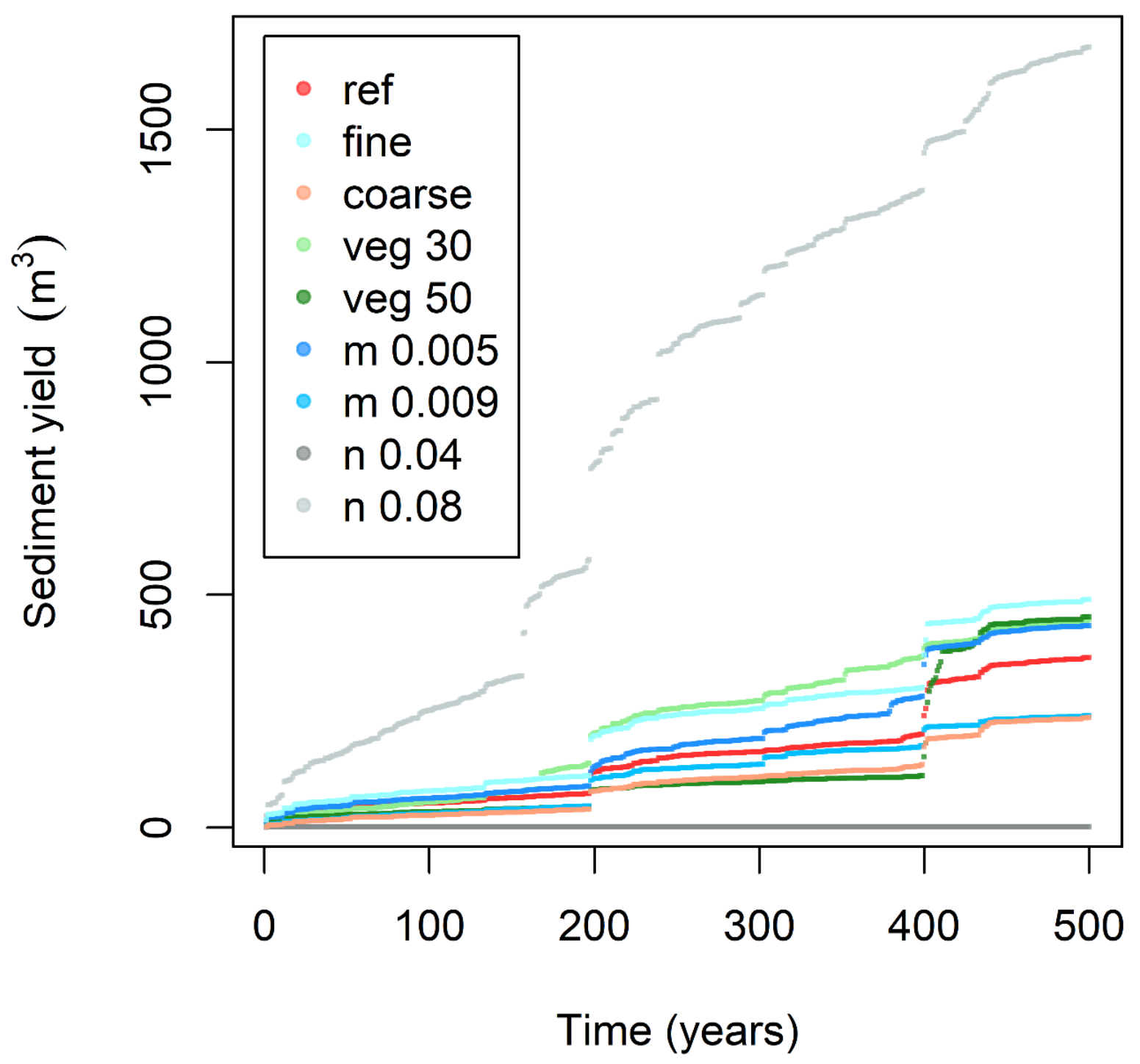

Figure 108. Cumulative yearly sediment yields from Whitman \#8 for all model runs used in the sensitivity analysis. Manning's $n$ had the most important affect with a change from 0.6 to 0.8 leading to $1314 \mathrm{~m}^{3}(\sim 360 \%)$ more sediment than the reference run. The model run with Manning's $n=0.04$ yielded almost zero sediment. This thought to be due to the calculation of bed shear stress (Pa) which uses Manning's $n$. 


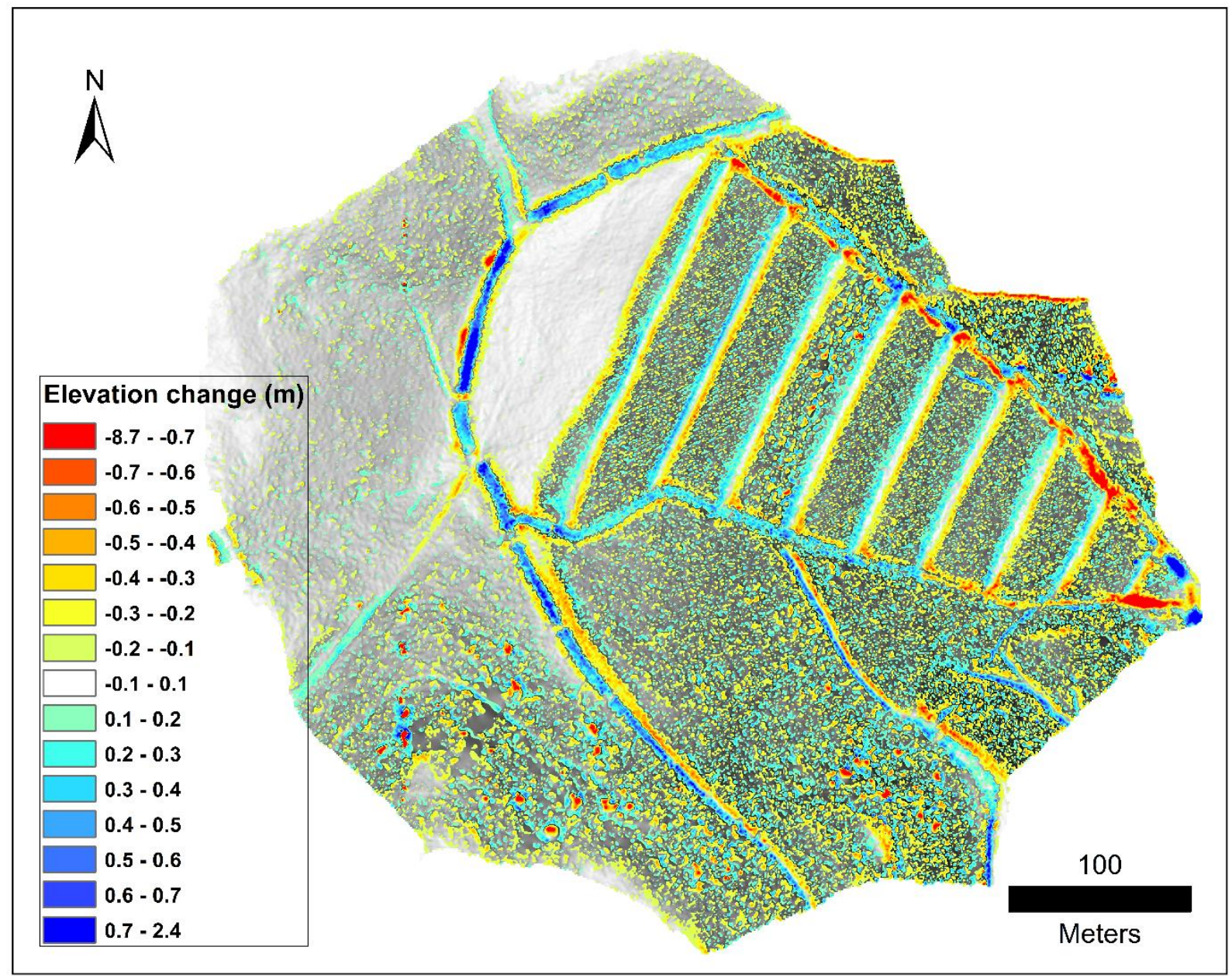

Figure 109. 500-year DoD from Whitman \#8 for the Manning's n of 0.8 run. This run yielded $1314 \mathrm{~m}^{3}$ more sediment than the 500-year reference run of Whitman \#8. This run also exhibited the most erosion within the groin drains with flows cutting into valley fill face sediments. 


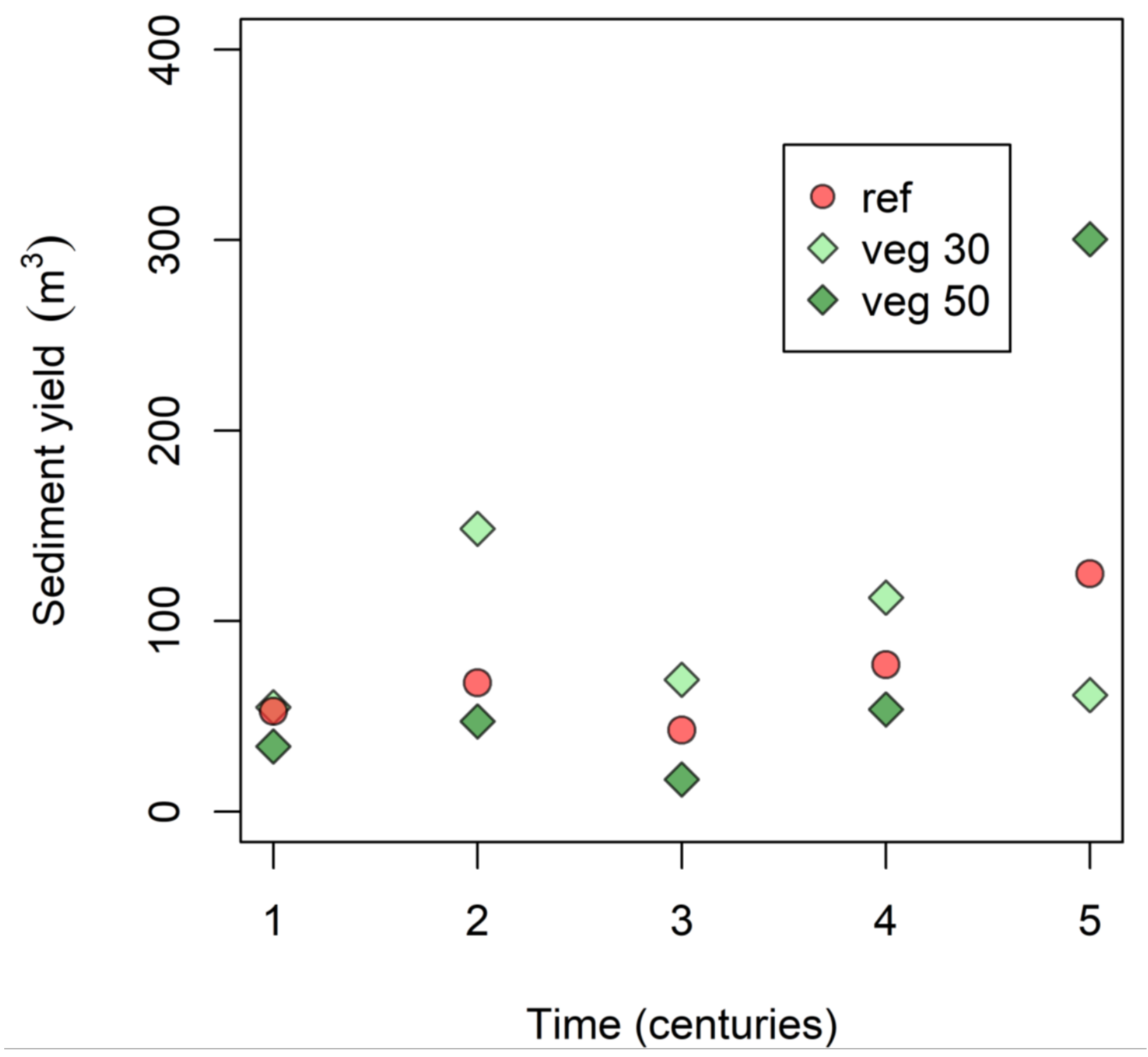

Figure 110. Centennial sediment yields from Whitman \#8 for the reference run and two runs with different values of vegetational critical shear stress $(\mathrm{Pa})$, the shear stress which denudes vegetation. The higher vegetational shear stress run, "veg 50", produced the largest centennial sediment yield (years 401-500). 


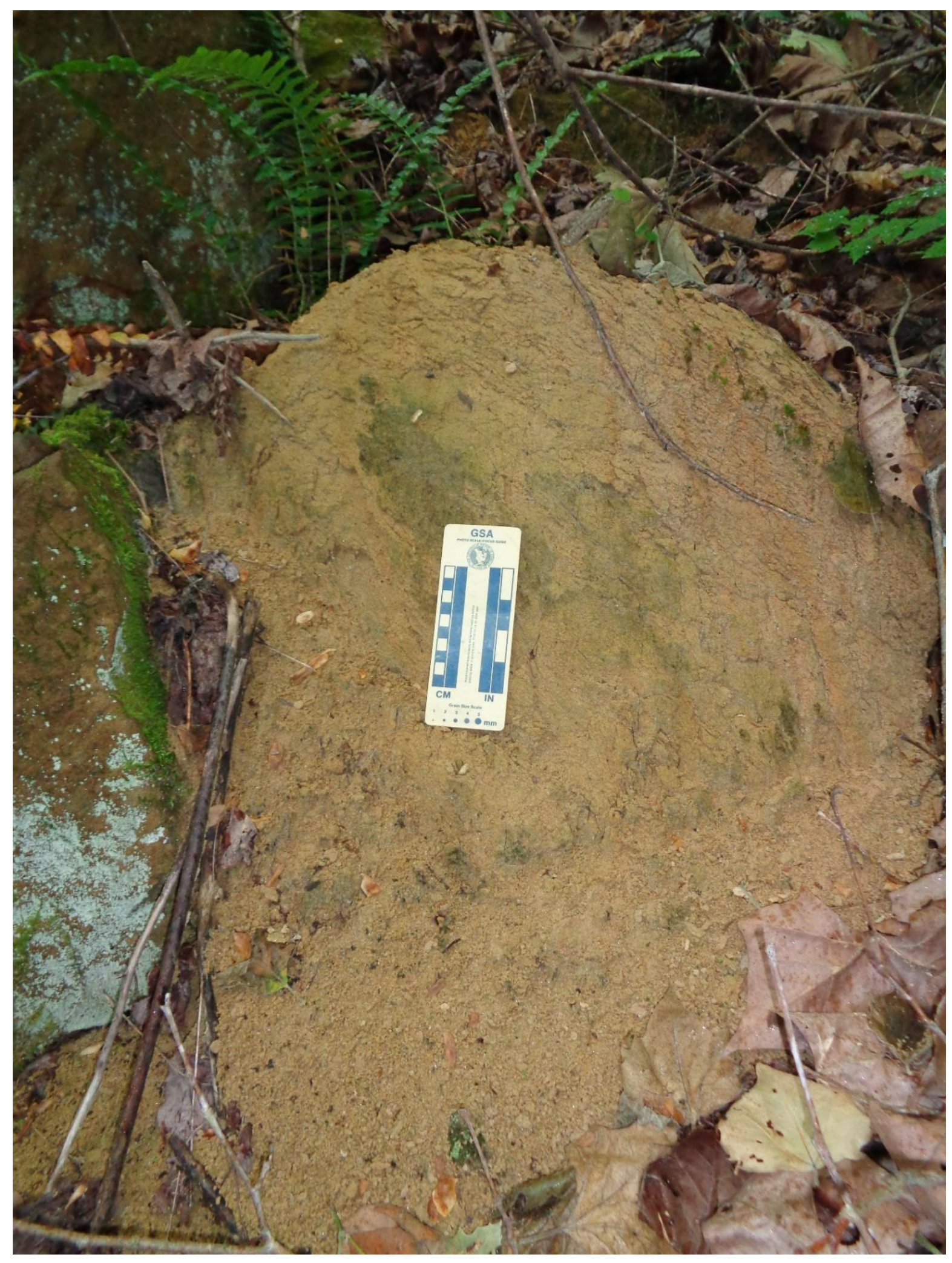

Figure 111. Granular disintegration of a sandstone boulder within a constructed drain of Whitman \#8 valley fill. The CAESAR-Lisflood landscape evolution model was not parameterized to include physical weathering of sediments. The model cannot simulate chemical weathering at this time. 
Table 1. Valley filled catchments assessed for erosional features. Age is derived from the West Virginia Department of Environmental Protection GIS shapefile, which shows the first year the valley fill could be detected via remote sensing methods.

\begin{tabular}{|c|c|c|c|c|c|}
\hline Catchment & Study area & $\begin{array}{l}\text { Drainage area } \\
\text { (ha) }\end{array}$ & Drainage style & Age & Notes \\
\hline 1 & EIP & 22.0 & Center & 2009 & N/A \\
\hline 2 & EIP & 15.9 & Center & 2009 & N/A \\
\hline 3 & EIP & 48.9 & Center & 2009 & N/A \\
\hline 4 & EIP & 52.1 & Groin & 2003 & Mitigated \\
\hline 5 & EIP & 14.9 & Center & 2003 & N/A \\
\hline 6 & EIP & 41.2 & Center & 2003 & N/A \\
\hline 7 & Whitman & 20.2 & Groin & 1996 & N/A \\
\hline 8 & Whitman & 18.6 & Groin & 1990 & N/A \\
\hline 9 & Whitman & 35.0 & Center & 1990 & Refuse fill \\
\hline 10 & Whitman & 26.1 & Center & 2003 & N/A \\
\hline 11 & Whitman & 11.6 & Center & 2003 & N/A \\
\hline 12 & Whitman & 30.1 & Center & 2003 & N/A \\
\hline 13 & Whitman & 23.4 & Center & 2003 & N/A \\
\hline 14 & Whitman & 28.7 & Center & 1984 & N/A \\
\hline 15 & Whitman & 16.8 & Center & 1990 & N/A \\
\hline 16 & Whitman & 46.6 & Center & Unknown & Refuse fill \\
\hline 17 & Whitman & 35.7 & Center & 2003 & N/A \\
\hline 18 & Whitman & 38.3 & Groin & 1996 & N/A \\
\hline 19 & Whitman & 30.4 & Center & 2003 & N/A \\
\hline 20 & Whitman & 20.1 & Center & 2003 & N/A \\
\hline 21 & Whitman & 46.1 & Center & 2003 & N/A \\
\hline
\end{tabular}


Table 2. LiDAR datasets used for manual classification of gullies and landslides.

\begin{tabular}{|c|c|c|c|}
\hline Dataset & Area $\left.\mathbf{( k m}^{\mathbf{2}}\right)$ & MTR/VF $\mathbf{( k m}^{2}$ ) & MTR/VF (\%) \\
\hline Holden, WV & 181.08 & 33.04 & 18.24 \\
\hline Cannelton, WV & 79.47 & 22.52 & 28.33 \\
\hline Amherstdale, WV & 199.02 & 51.63 & 25.94 \\
\hline Wharton, WV & 203.22 & 32.93 & 16.20 \\
\hline Clay-Nicholas, WV & 163.02 & 61.99 & 38.03 \\
\hline Birch River, WV & 81.72 & 23.14 & 28.31 \\
\hline Boone-Kanawha-Raleigh, WV & 144.74 & 47.68 & 32.94 \\
\hline Floyd-Pike, KY & 178.84 & 32.06 & 17.93 \\
\hline Perry-Knott-Breathitt, KY & 178.84 & 69.76 & 39.01 \\
\hline
\end{tabular}

Table 3. Valley filled catchments used in CAESAR-Lisflood (CL) landscape evolution modeling. Some DEMs had to be altered to let CL drain properly, including rotation and drainage area reduction. Three DEMs also included unerodable bedrock $2 \mathrm{~m}$ below the surface. HO is the Holden dataset. BKR is the Boone-Kanawha-Raleigh dataset.

\begin{tabular}{|c|c|c|c|l|}
\hline $\begin{array}{c}\text { Catchment } \\
\text { (dataset) }\end{array}$ & $\begin{array}{c}\text { Drainage area } \\
\text { (ha) }\end{array}$ & Drainage style & $\begin{array}{c}\text { Outlet slope } \\
\left(\mathbf{m ~ m}^{-1}\right)\end{array}$ & \multicolumn{1}{|c|}{ DEM details } \\
\hline Whitman \#8 (HO) & 18.6 & Groin & 0.15 & $\begin{array}{l}\text { Minor reduction in } \\
\text { area; bedrock }\end{array}$ \\
\hline Whitman \#18 (HO) & 38.3 & Groin & 0.14 & $\begin{array}{l}\text { Area reduced to } \\
\text { o.346 } \mathrm{km}^{2} ; \text { Rotated } \\
\text { 45 degrees }\end{array}$ \\
\hline Whitman \#20 (HO) & 20.1 & Center & 0.10 & $\begin{array}{l}\text { No reduction in } \\
\text { area; Rotated 45 } \\
\text { degrees }\end{array}$ \\
\hline Scarlet \#1 (HO) & 25.4 & Center & 0.10 & $\begin{array}{l}\text { Minor reduction in } \\
\text { area; Rotated 45 } \\
\text { degrees; bedrock }\end{array}$ \\
\hline BKR \#1 (BKR) & 37.8 & Groin & 0.16 & $\begin{array}{l}\text { Minor reduction in } \\
\text { area; bedrock }\end{array}$ \\
\hline
\end{tabular}


Table 4. Grain size distributions for all grain zones. Grain zones were delineated within each modeled catchment using LiDAR hillshades and Google Earth imagery. The "Base" grain size zone is located $2 \mathrm{~m}$ below any surface deemed "Mine soil" or "Drain".

\begin{tabular}{|r|c|c|c|c|}
\hline Grain size & $\begin{array}{c}\text { Base } \\
(\%)\end{array}$ & $\begin{array}{c}\text { Colluvial soil } \\
(\%)\end{array}$ & $\begin{array}{c}\text { Mine soil } \\
(\%)\end{array}$ & $\begin{array}{c}\text { Drain } \\
(\%)\end{array}$ \\
\hline $0.5 \mathrm{~mm}$ & 19.50 & 55 & 27.30 & 7.76 \\
\hline $1 \mathrm{~mm}$ & 5.50 & 10 & 7.70 & 2.19 \\
\hline $4 \mathrm{~mm}$ & 1.31 & 3 & 2.61 & 0.52 \\
\hline $8 \mathrm{~mm}$ & 1.71 & 5 & 3.42 & 0.68 \\
\hline $32 \mathrm{~mm}$ & 9.46 & 12 & 18.93 & 3.77 \\
\hline $64 \mathrm{~mm}$ & 10.21 & 11 & 21.35 & 4.06 \\
\hline $256 \mathrm{~mm}$ & 28.34 & 4 & 11.69 & 40.20 \\
\hline $512 \mathrm{~mm}$ & 17.65 & 0 & 7.00 & 38.79 \\
\hline $2048 \mathrm{~mm}$ & 6.32 & 0 & 0.00 & 2.03 \\
\hline
\end{tabular}

Table 5. Median grain size $\left(\mathrm{D}_{50}\right)$, sorting, and sediment name based on Folk and Ward (1957) for pebble counts within fluvially reworked portions of constructed drains. Grain size properties computed using the GRADISTAT spreadsheet of Blott (2010).

\begin{tabular}{|l|l|l|l|}
\hline Catchment & $\mathrm{D}_{50}(\mathrm{~mm})$ & Sorting & Name \\
\hline Whitman \#8 & 20 & Poor & Coarse gravel \\
\hline Whitman \#11 & 15 & Poor & Medium gravel \\
\hline Whitman \#13 & 12 & Poor & Medium gravel \\
\hline Whitman \#15 & 13 & Poor & Medium gravel \\
\hline Whitman \#17 & 12 & Moderately well & Medium gravel \\
\hline Whitman \#18 & 16 & Poor & Medium gravel \\
\hline Whitman \#18 (2) & 20 & Moderate & Coarse gravel \\
\hline Whitman \#20 & 14 & Poor & Medium gravel \\
\hline Whitman \#21 & 14 & Moderate & Medium gravel \\
\hline EIP \#1 & 16 & Moderate & Coarse gravel \\
\hline EIP \#4 & 24 & Poor & Coarse gravel \\
\hline EIP \#5 & 16 & Poor & Coarse gravel \\
\hline EIP \#6 & 14 & Moderate & Medium gravel \\
\hline
\end{tabular}


Table 6. Gully observations for 9 LiDAR datasets with the number of observed gullies, gullies per unit area, and percentage of each type. A description of the gully types can be found in Section

\begin{tabular}{|c|c|c|c|c|c|c|c|}
\hline Dataset & $\begin{array}{c}\text { \# of } \\
\text { Gullies }\end{array}$ & $\begin{array}{c}\text { Gullies } \\
\mathbf{p e r} \\
\mathbf{k m}^{\mathbf{2}}\end{array}$ & $\begin{array}{c}\text { Drainage } \\
(\boldsymbol{\%})\end{array}$ & $\begin{array}{c}\text { Roads } \\
\mathbf{( \% )}\end{array}$ & $\begin{array}{c}\text { Valley } \\
\mathbf{f i l l} \\
(\boldsymbol{\%})\end{array}$ & $\begin{array}{c}\text { Sideslope } \\
(\boldsymbol{\%})\end{array}$ & $\begin{array}{c}\text { Enlarged } \\
\text { Drain } \\
(\boldsymbol{\%})\end{array}$ \\
\hline Holden, WV & 82 & 2.5 & 62.2 & 12.2 & 8.5 & 4.9 & 12.2 \\
\hline Amherstdale, WV & 121 & 2.3 & 63.6 & 13.2 & 5.8 & 16.5 & 0.8 \\
\hline Cannelton, WV & 83 & 3.7 & 57.8 & 7.3 & 2.4 & 20.4 & 12.0 \\
\hline Wharton, WV & 59 & 1.8 & 66.1 & 11.9 & 5.1 & 11.9 & 5.1 \\
\hline Clay-Nicholas, WV & 82 & 1.3 & 57.3 & 25.6 & 6.1 & 4.9 & 2.4 \\
\hline Birch River, WV & 25 & 1.1 & 44.0 & 24.0 & 4.0 & 20.0 & 8.0 \\
\hline Boone-Kanawha-Raleigh, WV & 84 & 1.8 & 57.1 & 21.4 & 2.4 & 14.3 & 4.8 \\
\hline Floyd-Pike, KY & 106 & 3.3 & 39.6 & 12.3 & 12.3 & 23.6 & 12.3 \\
\hline Perry-Knott-Breathitt, KY & 349 & 5.0 & 33.5 & 9.5 & 24.9 & 15.2 & 16.9 \\
\hline
\end{tabular}


Table 7. CAESAR-Lisflood modeling results for all catchments. Five catchments were modeled for 1000 years under three different grain size distribution scenarios using the same rainfall to drive the model. Ref is for reference run, fine is for fine grain size distribution run, and coarse is for coarse grain size distribution run. Catchments with center drain-style valley fills are highlighted in red. The initial drainage density could not be extracted from the Whitman \#18 catchment due to irreparable software failure.

\begin{tabular}{|c|c|c|c|c|c|c|c|c|c|c|}
\hline \multirow[t]{2}{*}{ Catchment } & \multicolumn{3}{|c|}{$\begin{array}{c}\text { Sediment yield } \\
\left(\mathbf{m}^{3}\right)\end{array}$} & \multicolumn{3}{|c|}{$\begin{array}{c}\text { Erosion rate } \\
\left(\mathbf{m m ~ k y r} \mathbf{~ k}^{-1}\right)\end{array}$} & \multicolumn{4}{|c|}{$\begin{array}{l}\text { Drainage density } \\
\left(\mathbf{k m}^{-1}\right)\end{array}$} \\
\hline & Ref & Fine & Coarse & Ref & Fine & Coarse & Initial & Ref & Fine & Coarse \\
\hline Whitman \#20 & 3173 & 4332 & 1619 & 15.8 & 21.6 & 8.1 & 0.67 & 4.42 & 4.13 & 4.25 \\
\hline Whitman \#8 & 790 & 947 & 697 & 4.3 & 5.1 & 3.8 & 2.67 & 2.79 & 2.80 & 2.75 \\
\hline Whitman \#18 & 3254 & 4168 & 2398 & 8.5 & 10.8 & 6.2 & N/A & 3.33 & 3.38 & 3.18 \\
\hline Scarlet \#1 & 4885 & 6373 & 4054 & 19.2 & 25.1 & 15.9 & 1.20 & 3.67 & 3.98 & 4.06 \\
\hline Boone-Kanawha-Raleigh \#1 & 2552 & 3245 & 1603 & 6.7 & 8.6 & 4.2 & 4.24 & 6.53 & 6.10 & 6.71 \\
\hline
\end{tabular}

